NISTIR 7806

\title{
ANSI/NIST-ITL 1-2011 Requirements and Conformance Test Assertions
}

Christofer J. McGinnis

Dylan Yaga

Fernando L. Podio

National Institute of Standards and Technology U.S. Department of Commerce 


\section{ANSI/NIST-ITL 1-2011 Requirements and Conformance Test Assertions}

Christofer J. McGinnis

Dylan Yaga

Fernando L. Podio

September 2011

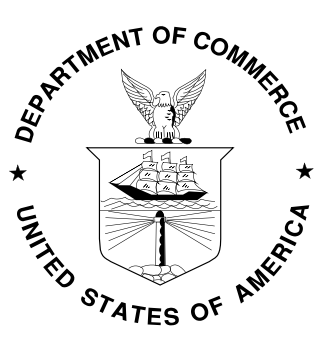

U.S. Department of Commerce Rebecca M. Blank, Acting Secretary

National Institute of Standards and Technology Patrick D. Gallagher, Under Secretary for Standards and Technology and Director 


\section{Reports on Computer Systems Technology}

The Information Technology Laboratory (ITL) at the National Institute of Standards and Technology (NIST) promotes the U.S. economy and public welfare by providing technical leadership for the Nation's measurement and standards infrastructure. ITL develops tests, test methods, reference data, proof of concept implementations, and technical analysis to advance the development and productive use of information technology. ITL's responsibilities include the development of technical, physical, administrative, and management standards and guidelines for the cost-effective security and privacy of sensitive unclassified information in Federal computer systems. This Interagency Report discusses ITL's research, guidance, and outreach efforts in computer security, and its collaborative activities with industry, government, and academic organizations.

\section{National Institute of Standards and Technology Interagency Report 175 pages (2011)}

Certain commercial entities, equipment, or materials may be identified in this document in order to describe an experimental procedure or concept adequately. Such identification is not intended to imply recommendation

or endorsement by the National Institute of Standards and Technology, nor

is it intended to imply that the entities, materials, or equipment are necessarily the best available for the purpose. 


\begin{abstract}
The current version of the ANSI/NIST-ITL standard "Data Format for the Interchange of Fingerprint, Facial \& Other Biometric Information" is specified in two parts. Part 1, ANSI/NIST-ITL 1-2007, specifies the traditional format, and Part 2, ANSI/NIST-ITL 2-2008, specifies a NIEM-conformant XML format. Both parts have been combined into one document, which is being revised and augmented. The Computer Security Division (CSD) of NIST/ITL has developed a set of test assertions based on the requirements specified in the $4^{\text {th }}$ draft of the new ANSI/NIST-ITL standard. Over twelve hundred test assertions have been identified and organized into a set of tables to assist in the development of a conformance test tool designed to test implementations of the new version of the ANSI/NIST-ITL standard for selected record types. These tables were contributed to the Conformance Testing Methodology (CTM) Working Group which was recently established by NIST/ITL to develop a CTM for the new version of the ANSI/NIST-ITL (AN-2011) standard. A ballot was conducted on a revised draft (5th draft) of the AN-2011 standard. A new draft will be developed based on the comments received as a result of this ballot. As the technical content of the AN-2011 draft standard evolves towards approval and publication, and comments on the assertion tables in this document are received, revised versions of these tables will be developed until they fully address the requirements of the approved AN-2011 standard. This publication documents the assertions developed and the terms, operands, and operators used in defining these assertions. Brief information on previous and ongoing conformance test tools development within NIST/ITL CSD is included.
\end{abstract}

\title{
Disclaimer
}

Statements made in this paper should not be interpreted as standards, guidelines, best practices, or recommendations for specific changes to any other NIST publications.

\section{Sponsor}

The work described in this document was sponsored, in part, by The Department of Homeland Security/US-VISIT Program. 


\section{Table of Contents}

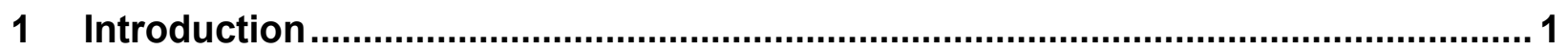

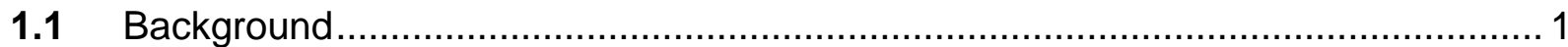

1.2 Need for Conformance Testing to Biometric Standards …................................... 1

1.3 NIST/ITL CSD Conformance Test Tools Developments ......................................... 1

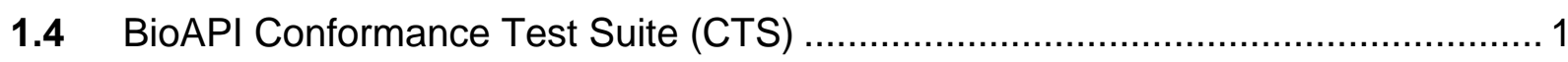

1.5 Conformance Test Architecture for Biometric Information Records - Beta 1.1 .......2

1.6 Advanced Conformance Test Architecture (CTA) Beta 2.0 ................................... 2

1.7 Support for the ANSI/NIST- ITL 1-2007 Standard ............................................ 2

1.8 Support for the ANSI/NIST-ITL 1-2011 (AN-2011) Standard ................................. 3

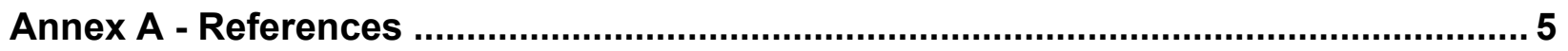

Annex B - Test Assertion Syntax and Testing Levels.................................................. 6

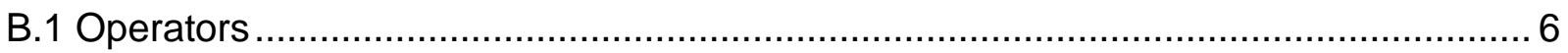

B.2 Terms

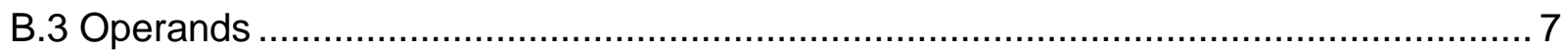

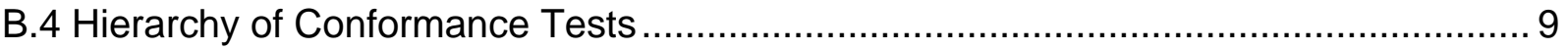

Annex C - Tables of Requirements and Assertions for AN-2011 4 ${ }^{\text {th }}$ Draft ................... 10

C.1 Changes in the tables from the respective AN-2007 table ..................................... 10

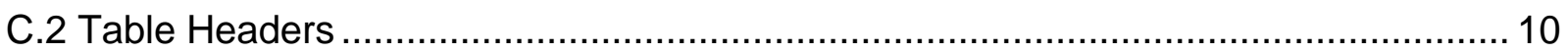

C.3 Assertion Tables for AN-2011 $4^{\text {th }}$ Draft.......................................................... 13

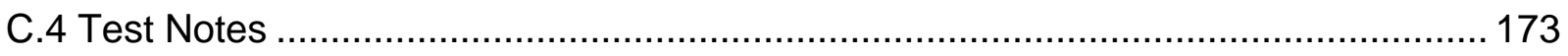

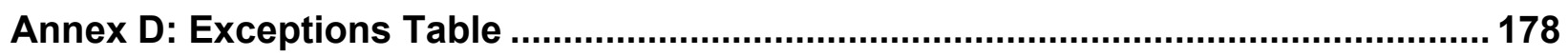

\section{List of Tables}

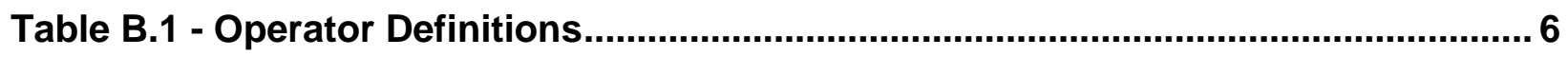

Table B.2 - Terms Used Throughout the Requirements and Assertion Tables ............. 7

Table B.3 - Operands Used Throughout the Requirements and Assertion Tables ....... 7

Table C.1 - Assertions for Data Conventions ............................................................... 13

Table C.2 - Assertions for Implementation Domain \& Application Profiles .................. 20

Table C.3 - Assertions for Information Associated with Several Records ................... 21

Table C.4 - Assertions for Record Type 1- Transaction Information Record ................56 


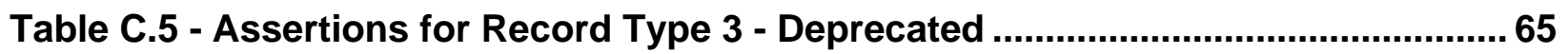

Table C.6 - Assertions for Record Type 4 - Grayscale Fingerprint Image .....................66

Table C.7 - Assertions for Record Type 5 - Deprecated ................................................. 71

Table C.8 - Assertions for Record Type 6 - Deprecated .................................................. 71

Table C.9 - Assertions for Record Type 10 - Facial, Other Body Parts \& SMT Image Record

Table C.10 - Assertions for Record Type 11 - Reserved for Voice ................................ 99

Table C.11 - Assertions for Record Type 12 - Reserved for Dental Records ................ 99

Table C.12 - Assertions for Record Type 13 - Friction-Ridge Latent Image Record.. 100

Table C.13 - Assertions for Record Type 14 - Fingerprint Image Record .................... 114

Table C.14 - Assertions for Record Type 15 - Palm Print Image Record ..................... 133

Table C.15 - Assertions for Record Type 17 - Iris Image Record...................................147

Table C.16 - Assertions for Annex B - Traditional Encoding …...................................165

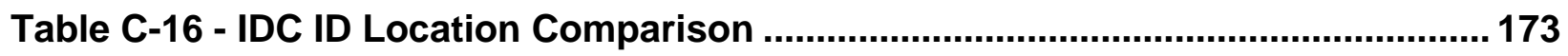

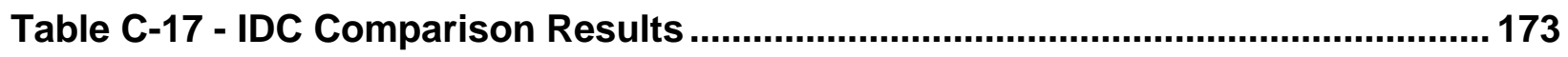

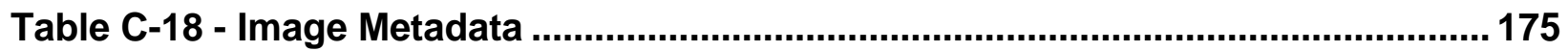

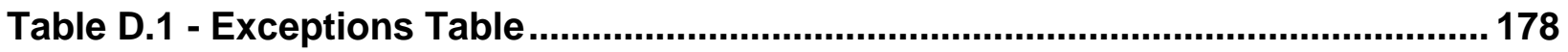




\section{Introduction}

\subsection{Background}

The ANSI/NIST-ITL standard "Data Format for the Interchange of Fingerprint, Facial \& Other Biometric Information" is used by law enforcement, intelligence, military, and homeland security organizations throughout the world. The current version of the ANSI/NIST-ITL standard is specified in two parts:

Part 1 - (ANSI/NIST-ITL 1-2007) in Traditional Format [1]

Part 2 - (ANSI/NIST-ITL 2-2008) in NIEM-conformant XML format [2]

In addition, an extension to the table of finger position codes in both parts of the standard to handle multiple-finger captures was published: ANSI/NIST-ITL 1a-2009 [3].

The standard is now in the process of being revised. Four drafts were developed as a result of two workshops that were held at NIST and comments received from subsequent drafts. A final voting version $\left(5^{\text {th }} \mathrm{draft}\right)$ was developed [4]. A forty-five day ballot on the $5^{\text {th }}$ draft closed August 31. A revised draft will be developed as a result of the ballot. Additional information on the standard and related activities can be found at the ANSI/NIST-ITL standard homepage [5].

\subsection{Need for Conformance Testing to Biometric Standards}

The existence of biometric standards alone is not enough to demonstrate that products meet the technical requirements specified in the standards. Conformance testing captures the technical description of a specification and measures whether an implementation faithfully implements the specification. Conformance testing provides developers, users, and purchasers with increased levels of confidence in product quality and increases the probability of successful interoperability.

The Computer Security Division (CSD) of NIST/ITL supports the development of biometric conformance testing methodology standards and other conformity assessment efforts through active technical participation in the development of biometric standards and the development of associated conformance test architectures and test suites.

\section{$1.3 \quad$ NIST/ITL CSD Conformance Test Tools Developments}

NIST/ITL CSD develops these conformance test tools to support users that require conformance to selected biometric standards and product developers interested in conforming to biometric standards by using the same testing tools available to users. These efforts support the possible establishment of conformity assessment programs to validate conformance to biometric standards. The following sections briefly describe previous, recent, and ongoing conformance test tool developments in support of biometric standards.

\subsection{BioAPI Conformance Test Suite (CTS)}

In February 2006, NIST/ITL CSD released a BioAPI Conformance Test Suite (CTS) developed to test implementations of ANSI INCITS 358-2002, the BioAPI specification. This software tool was developed to help users verify the conformance of Biometric Service Providers to the BioAPI Specification 1.1. This tool can be downloaded from the BioAPI Conformance Test Suite web page [6]. The InterNational Committee for Information Technology Standards (INCITS) Technical Committee M1- Biometrics developed a conformance testing methodology standard for this BioAPI 
specification. The standard was published in 2008 as ANSI INCITS 429-2008 [7]. NIST/ITL CSD co-sponsored the development of this standard.

\subsection{Conformance Test Architecture for Biometric Information Records - Beta 1.1}

In August 2008, NIST/ITL CSD released a Conformance Test Architecture (CTA) for Biometric Information Records and a Conformance Test Suite (CTS) for Patron Format A data structures specified in ANSI INCITS 398-2008, "Common Biometric Exchange Formats Framework" that runs under this CTA. The CTS for Patron Format A supported by this conformance testing architecture was developed to help users determine whether binary file implementations of Biometric Information Records (BIRs) based on this Patron Format conform to the standard. NIST/ITL CSD sponsored (in INCITS M1) development of a conformance testing methodology standard for CBEFF (Common Biometric Exchange Format Framework) data structures specified in ANSI INCITS 398-2008 and submitted to INCITS M1 the test assertions and related test cases developed for the Patron Format A CTS as well as test assertions and test cases for other Patron Formats specified in the ANSI INCITS 398-2008 standard. This standard was published as ANSI INCITS 473 in 2011 [8].

\subsection{Advanced Conformance Test Architecture (CTA) Beta 2.0}

In August 2010, NIST/ITL CSD released an advanced Conformance Test Architecture (CTA) Beta 2.0 designed to test implementations of selected national and international biometric data interchange standards. The CTA released was accompanied by the release of four Conformance Test Suites designed to test implementations of finger minutiae and finger image data formats conforming to American National Standards developed by Technical Committee M1- Biometrics [9]. These test tools, designed to test implementations of ANSI INCITS 378, "Finger Minutiae Format for Data Interchange" and ANSI INCITS 381, "Finger Image-Based Data Interchange Format" (both for the 2004 and 2009 versions), are available from the NIST/ITL CSD conformance test tools download web page [10].

A subsequent release of a Conformance Test Suite in 2011 is a tool designed to test implementations of the second generation of the iris image data interchange format developed by Joint Technical Committee 1 of ISO and IEC Subcommittee 37 (JTC 1/SC 37) - Biometrics [11]. Two versions of this test tool are available at the NIST/ITL CSD conformance test tools download web page [10]; they are an Installer version that runs under NIST/ITL CSD CTA Beta 2.0 and the source code version. These tools were released as soon as the final draft of this international standard became technically stable. At the time of this writing the Final Draft International Standard (FDIS) ballot closed on July 27, 2011 and the FDIS was approved. The standard is not yet published.

CTSs designed to test implementations of other international data formats developed in JTC 1/SC 37 are being tested before their release and others are under development. In addition, as addressed in the following sections, NIST/ITL CSD is also supporting the ANSI/NIST ITL standards by developing conformance test tools to test implementations of both the current version (2007) and the new version under development.

\subsection{Support for the ANSI/NIST- ITL 1-2007 Standard}

Although a revised and augmented version of the standard is under development, the 2007 version is still widely used. NIST/ITL CSD developed a CTA/CTS (Beta version 0.4) designed to test implementations of selected Record Types of ANSI/NIST-ITL 1-2007, "Data Format for the 
Interchange of Fingerprint, Facial, \& Other Biometric Information - Part 1". These Record Types were considered the first-priority tier and are supported:

- Record Type 1, Transaction Information Record

- Record Type 4, High-resolution grayscale fingerprint image

- Record Type 10, Facial and SMT image

- Record Type 13, Variable-resolution latent image

- Record Type 14, Variable-resolution fingerprint image

- Record Type 17, Iris image.

Over five-hundred and thirty test assertions were implemented. The software code can be extended to support other record types as required. The conformance test tool developed to support this standard is designed to detail a transaction's level of conformance to the standard. The CTA/CTS can also be used as an analysis tool for determining which parts of the transaction (e.g., nonconformant fields, records) do not conform to the standard and to analyze the reason for their nonconformance. For unsupported Record Types only the length of the record is reported during testing, and no determination of conformance is made for these records. In addition to stating whether a file passes or fails, the messages provided include warnings and notes. The code was developed in C\# under the Microsoft ${ }^{\circledR}$.NET 4.0 Framework. Two versions of the tools are available to the public: (a) an Installer version (Beta 0.4) and (b) the source code. Both versions were released in May 2011 and are available at the same NIST/ITL CSD conformance test tools download web page [10]. NISTIR 7791, "Conformance Test Architecture and Test Suite for ANSI/NIST-ITL 12007" [12], includes a high-level overview of the architecture and test suite as well as software details. The code structure description is provided. A quick start user guide and a comprehensive table of the standard's requirements and the associated implemented conformance test assertions are included.

\subsection{Support for the ANSI/NIST-ITL 1-2011 (AN-2011) Standard}

Part of the process associated with the development of a CTA/CTS designed to test implementations of AN-2011 would include similar and extended capabilities as the test tool described in the previous section. NIST/ITL CSD revised and extended the tables of operands and operators developed for the AN-2007 CTA/CTS assertions to express the assertions derived from the requirements in the AN2011 standard and developed requirements and assertion tables for the AN-2011 standard. These tables include, at the present time, over twelve-hundred assertions. This initial set of tables was developed based on the AN-2011 $4^{\text {th }} \mathrm{draft}$. NIST/ITL CSD contributed the requirements and assertions tables as well as the tables of terms, operands, and operators mentioned above to the Conformance Testing Methodology (CTM) Working Group which was recently established by NIST/ITL to develop a CTM for selected records types of AN-2011.

The CTM Working Group is led by NIST/ITL staff and has participation from NIST/ITL experts in conformance testing as well as experts from other US Government agencies and the private industry. The tables contained in the annexes include the terms, operands, and operators mentioned above, as well as the tables of requirements and assertions for the following sections and Record Types of the AN-2011 standard ( $4^{\text {th }}$ draft):

- Section 5: Data Conventions

- Section 7: Information Associated with Several Record Types 
- Section 8.1 Record Type-1: Transaction information record

- Section 8.4 Record Type-4: Grayscale fingerprint image

- Section 8.10Record Type-10: Facial, other body part and SMT image record

- Section 8.13 Record Type-13: Friction-ridge latent image record

- Section 8.14 Record Type-14: Fingerprint image record

- Section 8.15 Record Type-15: Palm print image record

- Section 8.17 Record Type-17: Iris image record

- Annex B: Traditional Encoding

Additionally, tables for the deprecated Record Types 3, 5, and 6 and reserved Record Types 11 and 12 are included. Implementation exceptions are identified in Annex D. The headers of the tables of requirements and assertions are based on those specified in the draft Conformance testing methodology for AN-2011 presented at the second AN-2011 Workshop, with minor changes listed below. These changes have been made to accommodate requirements and assertions from the AN2011 standard.

As the technical content of the AN-2011 draft standard evolves towards approval and publication and comments on the assertion tables included in Annex C are received, NIST/ITL CSD staff involved in the development of the AN-2011 CTM standard plans to revise the assertion tables until they fully address the requirements in the approved and published AN-2011 standard. 
Annex A - References

[1] NIST Special Publication 500-271, ANSI/NIST-ITL 1-2007 (Revision of ANSI/NIST-ITL 12000), American National Standard for Information Systems - Data Format for the Interchange of Fingerprint Facial, \& Other Biometric Information - Part 1

[2] NIST Special Publication 500-275, ANSI/NIST-ITL 2-2008 (XML Version of ANSI/NISTITL 1-2007), American National Standard for Information Systems — Data Format for the Interchange of Fingerprint Facial, \& Other Biometric Information - Part 2: XML Version

[3] Update to "Data Format for the Interchange of Fingerprint, Facial \& Other Biometric Information" for multiple finger capture designations ANSI/NIST ITL 1a-2009

[4] Draft NIST Special Publication 500-290, ANSI/NIST-ITL 1-2011, Information Technology: American National Standard for Information Systems - Data Format for the Interchange of Fingerprint, Facial \& Other Biometric Information http://biometrics.nist.gov/cs_links/standard/AN_2011_Voting_Version_July_2011.pdf

[5] ANSI/NIST Standard Homepage - http://www.nist.gov/itl/iad/ig/ansi_standard.cfm

[6] NIST/ITL's Biometric Application Programming Interface (BioAPI) Conformance Test Suite (CTS), http://www.nist.gov/itl/csd/biometrics/bioapicts.cfm

[7] ANSI INCITS 429:2008 Information technology - Conformance Testing Methodology for ANSI INCITS 358-2002 BioAPI Specification. Can be obtained from the ANSI eStore: http://webstore.ansi.org/

[8] ANSI INCITS 473:2011 Information Technology - Conformance Testing Methodology Standard for Patron Formats Conforming to INCITS 398-2008, Information Technology Common Biometric Exchange Formats Framework (CBEFF)

[9] INCITS M1 - Biometrics Public Homepage - http://standards.incits.org/a/public/group/m1

[10] NIST/ITL CSD Biometric Conformance Test Architectures and Test Suites Downloads Web Page: http://www.nist.gov/itl/csd/biometrics/biocta download.cfm

[11] ISO/IEC JTC1/SC 37 - Biometrics Public Homepage http://www.iso.org/iso/jtc1_sc37_home

[12] Conformance Test Architecture and Test Suite for ANSI/NIST-ITL 1-2007, NISTIR 7791, June 2011, Fernando L. Podio, Dylan Yaga, Christofer J. McGinnis http://csrc.nist.gov/groups/ST/BiomResCenter/CTA_BETA/NISTIR_7791.pdf 


\section{Annex B - Test Assertion Syntax and Testing Levels}

Test assertions are expressed according to the operators and operands found in the tables below, except for those instances where the assertion cannot be clearly or easily represented in a mathematical format. In those cases where English is used to express the assertion, the text will be contained within the $<>$ characters.

\section{B.1 Operators}

The table below includes a complete description of the operators used throughout the requirements and assertion tables.

Table B.1 - Operator Definitions

\begin{tabular}{|c|c|c|}
\hline \multicolumn{3}{|r|}{ Operator Definitions } \\
\hline Operator & Name & Description \\
\hline AND & Logical And & Tests if both values are true. \\
\hline ELSE & Else & Combined with the IF operator to specify what expressions are evaluated when the IF expression is false. \\
\hline EQ & Equal To & Tests for equality between two values. \\
\hline GT & Greater Than & Tests if the first value is greater than the second value \\
\hline GTE & Greater Than or Equal To & Tests if the first value is greater than or equal to the second value. \\
\hline IF & Logical If & Determines if the value or expression is true or false. \\
\hline IFF & IF and Only IF & Tests the bi-conditional where each of the first and second expressions implies the other. \\
\hline in & Container Specification & For $\mathrm{X}$ in $\mathrm{Y}$, selects only those $\mathrm{X}$ found in $\mathrm{Y}$. \\
\hline LT & Less Than & Tests if the first value is less than the second value. \\
\hline LTE & Less Than or Equal To & Tests if the first value is less than or equal to the second value. \\
\hline MO & Member Of & Tests if the value is a contained within the set. \\
\hline MOD & Modulo & For X MOD Y, provides the remainder of X divided by $\mathrm{Y}$. \\
\hline NEQ & Not Equal To & Tests for non-equality between two values. \\
\hline NOT & Negate & Negates any operator or expression that follows. \\
\hline OR & Logical Or & Tests if either value is true \\
\hline $\mathbf{P}: \mathbf{N}$ in $\mathbf{Q}$ & Query & Selects the Nth occurrence of P in Q. \\
\hline ST & Such That & Enforces a condition upon the specified value or expression. \\
\hline THEN & Then & Combined with the IF operator to specify what expressions are evaluated when the IF expression is true. \\
\hline to & Range Selection & For X to Y, selects a set of values Z ST Z GTE X AND LTE Y \\
\hline \# & All & Provides all valid values. \\
\hline : & Data Element Selection & For X:N, selects the Nth element in X. \\
\hline
\end{tabular}




\begin{tabular}{|c|l|l|}
\hline, & Range Concatenation & For X,Y, selects the set of values containing X and Y. \\
\hline$\cdot$ & Field Selection & For X.Y, selects the field specified by Y in Record X. \\
\hline$<>$ & English Expression & Contains English text that could not be reasonably expressed mathematically. \\
\hline\{\} & Value & For $\{\mathrm{X}\}$, provides the value of X. \\
\hline[] & Set & The set to be tested. \\
\hline
\end{tabular}

\section{B.2 Terms}

The table below provides a complete description of the terms used throughout the requirements and assertion tables.

Table B.2 - Terms Used Throughout the Requirements and Assertion Tables

\begin{tabular}{|c|c|c|}
\hline \multicolumn{3}{|r|}{ Term Definitions } \\
\hline Term & Name & Description \\
\hline Field(s) & Field & Field structure as defined by the AN 1-2011 standard. \\
\hline Integers & Integer Set & Set of all integers. \\
\hline NA & Not Applicable & The test or condition is not applicable. \\
\hline NULL & Null & Control character with no value. \\
\hline $\operatorname{Record}(\mathbf{s})$ & Record & Record structure as defined by the AN 1-2011 standard. \\
\hline RS_Subfield & RS Separated Subfield & Subfield separated by the ASCII RS separator character \\
\hline Subfield & US or RS Separated Subfield & Any field or information item separated by ASCII RS or US \\
\hline Transaction & Transaction & Transaction structure as defined by the AN 1-2011 standard. \\
\hline TRUE & True & The test always evaluates to true because the field cannot be checked against a known value \\
\hline US_Subfield & US Separated Subfield & Information Item separated by the ASCII US separator character \\
\hline
\end{tabular}

\section{B.3 Operands}

The table below includes a complete description of the operands (functions) used throughout the requirements and assertion tables. The parameter X may represent any combination of operands, terms, and operators.

Table B.3 - Operands Used Throughout the Requirements and Assertion Tables

\begin{tabular}{|c|l|l|}
\hline \multicolumn{2}{|c|}{ Operand Definitions } \\
\hline Operand & Name & Description \\
\hline All(X) & All Occurrences & Returns all occurrences of X. \\
\hline ASCII(X) & ASCII Values & Specifies that all values represented by X are ASCII values. \\
\hline Bytes(X) & Byte Data & Returns the byte data contained in X. \\
\hline
\end{tabular}




\begin{tabular}{|c|c|c|}
\hline Count(X) & Count Occurrences & Returns the number of occurrences of $\mathrm{X}$. \\
\hline DataLength $(X)$ & Length Of (without Special Characters) & Returns the length of $\mathrm{X}$ without counting Special Characters (such as US, RS, FS). \\
\hline FieldNumber(X) & Field Number & Returns the field number of $X$. \\
\hline First(X) & First Occurrence & Returns the first occurrence of $X$. \\
\hline $\begin{array}{l}\text { For(X EQ A to B) } \\
\{\text { Expression(s) }\}\end{array}$ & For Loop & Evaluates each Expression for the range specified by A to B. \\
\hline $\begin{array}{c}\text { ForEach }(\mathbf{X}) \\
\{\operatorname{Expression}(\mathbf{s})\}\end{array}$ & For Each & Evaluates each Expression for every occurrence of $\mathrm{X}$ found. \\
\hline Last $(X)$ & Last Occurrence & Returns the last occurrence of $\mathrm{X}$. \\
\hline Length $(\mathrm{X})$ & Length Of & Returns the length of $\mathrm{X}$. \\
\hline $\operatorname{Max}(X)$ & Maximum Value & Returns the maximum value in the set $X$. \\
\hline $\operatorname{MaxOccurrences}(\mathrm{X})$ & Maximum Occurrences & $\begin{array}{l}\text { Returns the maximum number of occurrences of } X \text { allowed by the 1-2011 } \\
\text { standard. }\end{array}$ \\
\hline $\operatorname{Max} \operatorname{Size}(\mathbf{X})$ & Maximum Size & Returns the maximum size of X per occurrence allowed by the 1-2011 standard. \\
\hline $\operatorname{Min}(\mathbf{X})$ & Minimum Value & Returns the minimum value in the set $\mathrm{X}$. \\
\hline MinOccurrences $(\mathbf{X})$ & Minimum Occurrences & $\begin{array}{l}\text { Returns the minimum number of occurrences of X allowed by the 1-2011 } \\
\text { standard. }\end{array}$ \\
\hline $\operatorname{MinSize}(\mathbf{X})$ & Minimum Size & Returns the minimum size of X per occurrence allowed by the 1-2011 standard. \\
\hline $\operatorname{Next}(\mathbf{X})$ & Next Occurrence & $\begin{array}{l}\text { Returns the next occurrence of X. Only for use within ForEach Operand's } \\
\text { Expression(s). }\end{array}$ \\
\hline Pair(A,B) of X & Pair & Returns all pairs of X. Only for use as a parameter in a ForEach Operand. \\
\hline ParentField(X) & Parent Field & Returns the Field that contains X. \\
\hline ParentRecord(X) & Parent Record & Returns the Record that contains X. \\
\hline $\operatorname{Present}(\mathbf{X})$ & Value Present & $\begin{array}{l}\text { Returns TRUE if } X \text { is present, FALSE otherwise. For subfields in Traditional } \\
\text { Encoding, the US and RS separators are always present. Therefore the Present }(X) \\
\text { operand returns TRUE if the value between the separators is present. }\end{array}$ \\
\hline $\operatorname{Previous}(\mathbf{X})$ & Previous Occurrence & $\begin{array}{l}\text { Returns the previous occurrence of X. Only for use within ForEach Operand's } \\
\text { Expression(s). }\end{array}$ \\
\hline Second $(X)$ & Second Occurrence & Returns the second occurrence of X. \\
\hline $\operatorname{Sum}(\mathbf{X})$ & Summation & Returns the summation of all the values that are a member of $\mathrm{X}$. \\
\hline Type(X) & Record Type & Returns the Record Type of X. \\
\hline $\begin{array}{l}\text { Var(X) }\{\text { Selection } \\
\text { Statement }\}\end{array}$ & Variable & $\begin{array}{l}\text { Assigns the entity specified by the Selection Statement to the name X. The } \\
\text { assignment is valid for the remainder of the assertion text. }\end{array}$ \\
\hline $\mathbf{X E} \operatorname{Em}(\mathbf{X})$ & XML Element & Returns the XML Element with name X. \\
\hline
\end{tabular}




\section{B.4 Hierarchy of Conformance Tests}

Three levels of conformance testing are defined below. For each assertion included in the Tables of Requirements and Assertions in Annex $\mathrm{C}$ a level of conformance testing is indicated. See Table Headers in C.2 below.

\section{Level 1 - Checking internal content}

In Level 1 testing, an AN-2011 transaction(s) is checked for field-by-field, subfield-by-subfield and information item-by information item conformance with the specification of the standard, both in terms of ranges, character types, and cardinality. Since Level 1 testing can be performed by a simple field-by-field, subfield-by-subfield and information item-by information item reading of the standard and comparison to known values, and their encoding, performing this level of conformance testing only requires a transaction or a set of ANSI/NIST transactions (as opposed to a computer algorithm or a set of hardware and software). Therefore, any hardware or software components of the implementation being tested do not have to come into the possession of the testing lab. Only AN-2011 transactions created with those components need to be available.

\section{Level 2 - Internal consistency checking}

In Level 2 testing, an AN-2011 transaction(s) is checked to determine if it is internally consistent. This is achieved by relating values from one or more fields, subfields, or information items within a transaction to other values within the same transaction. Level 2 tests involve interactions between multiple values from different parts of the AN-2011 standard and sometimes from implicit assumptions that are not explicitly stated in the base standard. Thus, Level 2 tests require more complex validation than Level 1. Similar to Level 1 testing, Level 2 conformance testing only requires an AN-2011 transaction(s). To ensure that all (or almost all) possible internal consistency checks are tested, tests are performed whenever possible with a large number of transactions representing as many as possible different structural variants.

\section{Level 3 - Content checking}

A Level 3 test is intended to test whether an AN-2011 transaction under test is a faithful representation of the original biometric data and that it satisfies those requirements of the standard that are not simply a matter of syntax and format. This level of conformance testing for some requirements might be significantly difficult or even impossible to test.

The requirements and assertion tables indicate whether Level 1 or Level 2 conformance testing is required to address the assertion identified in the test assertion. Level 3 conformance tests are indicated only when necessary to show that the requirement is not currently testable or addressed. 


\section{Annex C - Tables of Requirements and Assertions for AN-2011 $4^{\text {th }}$ Draft}

\section{1 Changes in the tables from the respective AN-2007 table}

The following changes have been made from equivalent tables developed for the AN-2007 version of the standard:

- Some Operators, Operands, and Terms have been modified or added to express new assertions.

- Changes have been made for requirements addressing character counts within fields. While the AN-2007 standard included special characters $(0 \times 1 \mathrm{E}$ and $0 \mathrm{x} 1 \mathrm{~F})$ in the count, the AN-2011 standard does not. This is reflected in the AN-2011 tables, which do not include special characters for character counts of fields.

- The $<>$ operator is used in the Requirements Summary column of the tables to represent text not found in the standard. This may be done in cases where the requirement is implied but not stated. The $<>$ operator is used in the Test Assertions column to represent text that could not be expressed mathematically according to the Operators, Operands, and Terms listed in the tables in Annex A.

\section{C.2 Table Headers}

The following table headers are based on those specified in the Conformance Testing Methodology for AN-2011 (5 $5^{\text {th }}$ Draft). However, some minor changes have been made. The "Mnemonic" column was removed because the Mnemonic is now listed either in the Requirement or Assertion ID columns were appropriate. "Section" was changed to "Reference in Base Standard" to allow values other than clause numbers (such as table numbers and annexes).

The following describe the the headings of the requirements and assertions tables included below:

- Requirement ID: Defines a unique identifier for the requirement and associated assertion or set of assertions. It provides reference to the type of requirement (e.g., transaction, record, and field). The Requirement ID is in the form of "Type: Description" where type may be "Transaction", "Record", or "Field". For requirements found in Annex B of the AN-2011 standard, the Requirement ID is preceded by "Traditional-".

- Reference in Base Standard: Identifies the clause where the requirement is included in the standard. In some cases the reference includes additional information such as a Table number. This header corresponds to the Section header in the Conformance Testing Methodology for AN-2011 ( $5^{\text {th }} \mathrm{draft}$ ), but allows references other than clause numbers (i.e., tables, annexes). 
- Requirement Summary: Provides a summary of the requirement detailed as textual information or an interpretation of the requirement in the standard. It carries the essentials of the requirement but may not provide all the text necessary to understand it. The $<>$ operator is used in the Requirement Summary column of the tables to represents text not found in the standard, but that may help indicate what requirement is being represented.

- Level: Indicates whether Level 1 or Level 2 conformance testing is required to address the assertion identified in the Assertion ID column of the same row. Level 3 conformance tests are indicated only when necessary to show that the requirement is not currently testable or addressed.

- Status: Reflects the status specified in the standard:

○ M: Mandatory

○ O: Optional

○ D: Dependent

○ M $M$ : Mandatory if field/repeating subfield present

○ O介: Optional if field/repeating subfield present for the field or subfield associated with the assertion.

○ -: Varying statuses. The assertion addresses many fields or subfields of multiple statuses.

- Assertion ID: Defines an identifier of a specific test assertion within the set of test assertions associated with a requirement.

- Test Assertion: Provides, whenever possible, a mathematical equation or a procedure using the language specified by the $\underline{\text { Operators, }}$ $\underline{\text { Operands, and Terms. }}$

0 The $<>$ operator is used to contain plain text whenever a mathematical formula or simple procedure cannot be detailed.

- Test Note: Contains a number of a note included below the table. The test note may include a test procedure when the complexity of the test assertion does not allow this procedure to be included in the test assertion column. It could also include an explanatory note related to the assertion's implementation. Additionally, all exceptions (requirements specified by the standard but where the assertion is not included are listed as test notes. Finally, in instances where contradictions or perceived discrepancies are present in the standard, test notes may be used to clarify the approach taken in the assertion tables.

- Implementation Support: Denotes a supplier's implementation support of a particular requirement ("Y"/"N"). A note can follow the table when providing more details of implementation support (or the lack of it) is required.

- Supported Range: Indicates a range of values supported, especially when it is different than the full range of values specified in the standard. When an information item is specified as a single value, or does not address a range of values, a N/A should be used. 
- Test Result: This column is used to denote the test results. For file and record-level results the results are either "Pass" or "Fail". The field-level results should be indicated as "Ok" "Error", "Warning" and "Note". Explanatory notes can be added below the table.

- Applicability: This table header indicates which assertions differ (in values required or conditions) between Traditional and NIEM encoding. This table header does not indicate which assertions are addressed by the XML Schema and which will need to be addressed in code. Valid values are:

○ T: The assertion only applies to the Traditional encoding as described in Annex B.

○ $\mathrm{X}$ : The assertion only applies to the NIEM-conformant (XML) encoding as described in Annex C.

○ B: The assertion is applicable to both Traditional and NIEM (XML) encoding.

- Following the conventions in the AN-2011 standard, test Assertions are expressed using constructs (fields, records, etc.) found in Traditional encoding (such as xx.002 for the second field of each record type). The same assertion applies for the XML elements that correspond to the Traditional constructs. For example, 10.006 in Traditional Encoding corresponds to XML Element <biom:ImageHorizontalLineLengthPixelQuantity>.

- Some assertions reference subfields, however, NIEM encoding uses nested elements. Expression of Test Assertions that include subfields in the XML encoding requires further review. These assertions are listed with the following applicability values:

- $\mathrm{X}^{*}$ indicates that the assertion applies only to NIEM-conformant (XML) encoding.

- $\quad \mathrm{B}^{*}$ indicates that the assertion is applicable to both Traditional and NIEM (XML) encodings. 


\section{C.3 Assertion Tables for AN-2011 $4^{\text {th }}$ Draft}

Table C.1 - Assertions for Data Conventions

\begin{tabular}{|c|c|c|c|c|c|c|c|c|c|c|c|}
\hline $\begin{array}{l}\text { Requireme } \\
\text { nt } \\
\text { ID }\end{array}$ & $\begin{array}{l}\text { Referen } \\
\text { ce in } \\
\text { Base } \\
\text { Standar } \\
\quad \text { d }\end{array}$ & $\begin{array}{l}\text { Requirement } \\
\text { Summary }\end{array}$ & $\begin{array}{l}\text { L } \\
\text { e } \\
\text { v } \\
\text { e } \\
\text { I }\end{array}$ & $\begin{array}{l}\mathrm{S} \\
\mathrm{t} \\
\mathrm{a} \\
\mathrm{t} \\
\mathrm{u} \\
\mathrm{s}\end{array}$ & $\begin{array}{l}\text { Assertion } \\
\text { ID }\end{array}$ & $\begin{array}{c}\text { Test } \\
\text { Assertion }\end{array}$ & $\begin{array}{c}\text { Test } \\
\text { Note }\end{array}$ & $\begin{array}{l}\text { Implemen } \\
\text { tation } \\
\text { Support }\end{array}$ & $\begin{array}{l}\text { Supporte } \\
\text { d Range }\end{array}$ & $\begin{array}{l}\text { Test } \\
\text { Result }\end{array}$ & $\begin{array}{l}\text { Applicab } \\
\text { ility }\end{array}$ \\
\hline \multicolumn{12}{|c|}{ 5: Data Conventions } \\
\hline \multirow[t]{2}{*}{$\begin{array}{l}\text { Transaction: } \\
\text { Required } \\
\text { Record Types }\end{array}$} & \multirow[t]{2}{*}{$\begin{array}{l}5.1 \\
\text { Table } 1\end{array}$} & \multirow[t]{2}{*}{$\begin{array}{l}\text { There shall be at least one data record } \\
\text { accompanying a Record Type- } 1 \text {. The } \\
\text { Record types are listed in Table } 1 .\end{array}$} & 1 & M & $\begin{array}{l}\text { Transaction } \\
\text {-Required } \\
\text { Records }\end{array}$ & $\begin{array}{l}\text { Present(Record ST Type(Record) EQ 1) } \\
\text { AND } \\
\text { Present(Record ST Type(Record) MO [2 to 99]) } \\
\text { AND NOT MO [3,5,6,11,12,22 to 97]) }\end{array}$ & & & & & $\mathrm{T}$ \\
\hline & & & 1 & M & $\begin{array}{l}\text { NIEM- } \\
\text { Transaction } \\
\text {-Required } \\
\text { Records }\end{array}$ & $\begin{array}{l}\text { Present(XEIm(itl:PackagelnformationRecord)) } \\
\text { AND } \\
\text { Count(Records) GTE } 2\end{array}$ & & & & & $x$ \\
\hline $\begin{array}{l}\text { Transaction: } \\
\text { Single Subject }\end{array}$ & 5.1 & $\begin{array}{l}\text { All records in a transaction shall pertain to } \\
\text { a single subject. Biometric data used to } \\
\text { identify another individual requires a } \\
\text { separate transaction. }\end{array}$ & 3 & M & $\begin{array}{l}\text { Transaction } \\
\text {-Single } \\
\text { Subject }\end{array}$ & $<$ Not tested. $>$ & $\mathrm{t}-1$ & & & & B \\
\hline $\begin{array}{l}\text { Transaction: } \\
\text { Records } \\
\text { Transmitted } \\
\text { Together }\end{array}$ & 5.1 & $\begin{array}{l}\text { All of the records belonging to a single } \\
\text { transaction shall be transmitted together. }\end{array}$ & 3 & M & $\begin{array}{l}\text { Transaction } \\
\text {-Records } \\
\text { Together }\end{array}$ & $<$ Not tested. $>$ & $\mathrm{t}-1$ & & & & B \\
\hline $\begin{array}{l}\text { Transaction: } \\
\text { Record } \\
\text { Occurrences }\end{array}$ & 5.1 & $\begin{array}{l}\text { There may be multiple records in a } \\
\text { transaction of each record type other } \\
\text { than Type-1. }\end{array}$ & 1 & $M$ & $\begin{array}{l}\text { Transaction } \\
\text {-Record } \\
\text { Occurrence } \\
\text { s }\end{array}$ & TRUE & & & & & B \\
\hline $\begin{array}{l}\text { Transaction: } \\
\text { Size }\end{array}$ & 5.2 & $\begin{array}{l}\text { Although the } 2007 \text { and } 2008 \text { versions of } \\
\text { the standard stated "... there is no upper } \\
\text { limit on the number of logical records } \\
\text { that may be present in a file..." there was } \\
\text { an effective upper limit due to the field } \\
\text { size limits specified in the } 2007 \text { version } \\
\text { (but not the } 2008 \text { version). This limit was }\end{array}$ & 1 & M & $\begin{array}{c}\text { Transaction } \\
\quad \text { Size }\end{array}$ & Count(Records in Transaction) LTE 1000 & & & & & B \\
\hline
\end{tabular}




\begin{tabular}{|c|c|c|c|c|c|c|c|c|}
\hline & & $\begin{array}{l}3 \text { ASCII } 2 \text { characters for the information } \\
\text { item holding the total number of records } \\
\text { of type } 2 \text { through } 99 \text {; thus an upper limit } \\
\text { of } 999 \text { such records. With the addition of } \\
\text { a Type- } 1 \text { record, the maximum number of } \\
\text { records in a transaction was thus } \\
\text { restricted to } 1000 \text {. This upper limit of } \\
1000 \text { records is maintained in this version } \\
\text { of the standard to ensure backward } \\
\text { compatibility with the } 2007 \text { version. }\end{array}$ & & & & & & \\
\hline \multirow{2}{*}{$\begin{array}{l}\text { Transaction: } \\
\text { Reserved } \\
\text { Records }\end{array}$} & \multirow[t]{2}{*}{$\begin{array}{c}5.3 \\
\text { Table } 1\end{array}$} & \multirow{2}{*}{$\begin{array}{l}11 \text { Voice Data (future) } \\
12 \text { Dental Record (future) } \\
22-97 \text { reserved for future use. }\end{array}$} & 1 & M & $\begin{array}{l}\text { Records- } \\
\text { Reserved }\end{array}$ & $\begin{array}{l}\text { NOT Present(Records ST Type(Records) MO } \\
[11,12,22 \text { to } 97])\end{array}$ & & $\mathrm{T}$ \\
\hline & & & 1 & M & $\begin{array}{l}\text { NIEM- } \\
\text { Records_Re } \\
\text { served }\end{array}$ & $\begin{array}{l}<\text { An invalid record type will cause a parsing error } \\
\text { in XML because no Record Element Tag is } \\
\text { defined (see Table 97).> }\end{array}$ & & $x$ \\
\hline \multirow{2}{*}{$\begin{array}{l}\text { Transaction: } \\
\text { Type1- } \\
\text { Occurrences }\end{array}$} & \multirow[t]{2}{*}{5.3 .1} & \multirow{2}{*}{$\begin{array}{l}\text { Transmissions to be exchanged are } \\
\text { required to contain one and only one } \\
\text { Type-1 record per transaction. }\end{array}$} & 1 & M & $\begin{array}{l}\text { Type1_Occ } \\
\text { ur_Once }\end{array}$ & $\begin{array}{l}\text { Count(Records in Transaction ST Type(Record) } \\
\text { EQ 1) EQ } 1\end{array}$ & & $\mathrm{~T}$ \\
\hline & & & 1 & M & $\begin{array}{l}\text { NIEM- } \\
\text { Type1_Occ } \\
\text { ur_Once }\end{array}$ & Count(XEIm(itl:PackagelnformationRecord)) EQ 1 & & $x$ \\
\hline \multirow{2}{*}{$\begin{array}{l}\text { Transaction: } \\
\text { Type1- } \\
\text { Record_First }\end{array}$} & \multirow[t]{2}{*}{5.3 .1} & \multirow{2}{*}{$\begin{array}{l}\text { The Type- } 1 \text { record shall always be the first } \\
\text { record within the transaction. }\end{array}$} & 1 & M & Type1_First & Type(First(Record in Transaction)) EQ 1 & & $\mathrm{~T}$ \\
\hline & & & 1 & M & $\begin{array}{l}\text { NIEM- } \\
\text { Type1_First }\end{array}$ & $\begin{array}{l}\text { First(Record in Transaction) EQ } \\
\text { XEIm(itll:PackagelnformationRecord) }\end{array}$ & & $x$ \\
\hline $\begin{array}{l}\text { Transaction: } \\
\text { Type1- One } \\
\text { More Record }\end{array}$ & 5.3 .1 & $\begin{array}{l}\text { At least one more record shall be present } \\
\text { in the file. }\end{array}$ & 1 & M & $\begin{array}{l}\text { Type1-One } \\
\text { More } \\
\text { Record }\end{array}$ & $\begin{array}{l}<\text { See Requirement ID "Transaction: Required } \\
\text { Record Types"> }\end{array}$ & $\mathrm{t}-2$ & \\
\hline $\begin{array}{l}\text { Record: } \\
\text { Type1- } \\
\text { Contents }\end{array}$ & 5.3 .1 & $\begin{array}{l}\text { The Type-1 record shall provide } \\
\text { information describing type and use or } \\
\text { purpose for the transaction involved, a } \\
\text { listing of each record included in the } \\
\text { transaction, the originator or source of } \\
\text { the physical record, and other useful and } \\
\text { required information items. }\end{array}$ & & M & $\begin{array}{l}\text { Type1_Con } \\
\text { tents }\end{array}$ & $\begin{array}{l}<\text { The test assertions are included under field } \\
\text { testing for Record Type-1: Transaction } \\
\text { Information Record.> }\end{array}$ & $\mathrm{t}-2$ & \\
\hline $\begin{array}{l}\text { Record: } \\
\text { Type2- } \\
\text { Contents }\end{array}$ & 5.3 .2 & $\begin{array}{l}\text { Type- } 2 \text { records shall contain user-defined } \\
\text { textual fields providing identification and } \\
\text { descriptive information associated with } \\
\text { the subject of the transaction. }\end{array}$ & & M & $\begin{array}{l}\text { Type2_Con } \\
\text { tents }\end{array}$ & $\begin{array}{l}<\text { The test assertions for this type may not be } \\
\text { supported in this version of the CTM. If they are } \\
\text { supported, they are included under field testing } \\
\text { for Record Type-2: User-defined descriptive text } \\
\text { record .> }\end{array}$ & $\mathrm{t}-2$ & \\
\hline $\begin{array}{l}\text { Record: } \\
\text { Type2- } \\
\text { DOM/APS }\end{array}$ & 5.3 .2 & $\begin{array}{l}\text { Each entry in a Type-2 record shall have a } \\
\text { definition and format that is listed with } \\
\text { the Domain owner. Data contained in this } \\
\text { record shall conform in format and } \\
\text { content to the specifications of the } \\
\text { domain name(s) as listed in Field } 1.013 \\
\text { Domain name / DOM found in the Type-1 }\end{array}$ & 3 & M & $\begin{array}{l}\text { Type2_DO } \\
\text { M/APS }\end{array}$ & $<$ Not Tested.> & $t-3$ & B \\
\hline
\end{tabular}




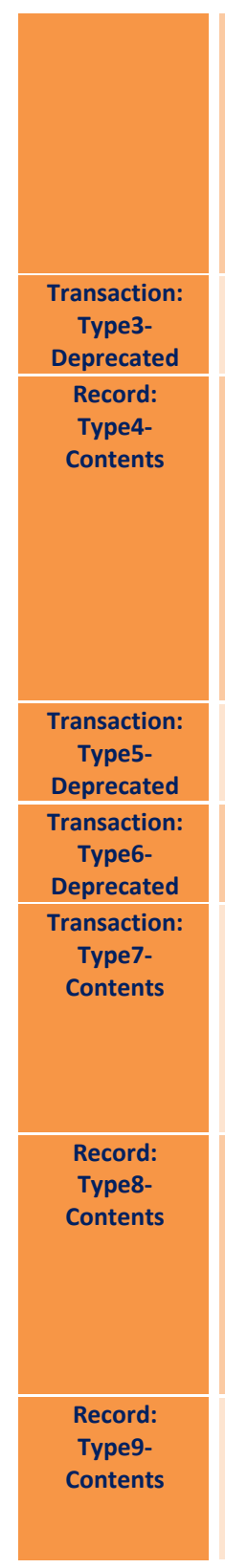

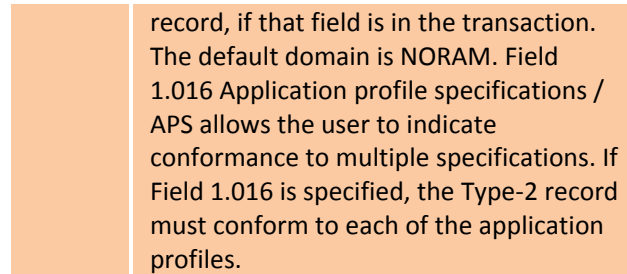

5.3.3, Record Type-3 shall not be contained in

Table 1 transactions conforming to this version of the standard.

\begin{tabular}{|l|l|} 
5.3.4 & Type-4 records were designed to convey
\end{tabular} fingerprint images captured by an

Automated

Fingerprint Identification System (AFIS) live-scan reader, or other image capture devices operating at a nominal scanning resolution of 500 pixels per inch (ppi).

Many systems still use this record type and it will remain an integral part of the standard.

5.3.5, Record Type-5 shall not be contained in

Table 1 transactions conforming to this version of the standard.

5.3.6, Record Type-6 shall not be contained in

Table 1 transactions conforming to this version of the standard.

\begin{tabular}{|l|l} 
5.3.7 & Type-7 is a legacy record type. It was
\end{tabular} intended as a temporary measure to enable the exchange of image data that would be defined by specific record types in later versions of the standard. Since some older systems still use this record type, it is included in the standard.

5.3.8 Type-8 records shall be used for scanned binary or vectored signature image data. Each

Type-8 record shall contain data representing the signature of the subject from whom the biometric sample is being collected and/or the operator capturing biometric data.

5.3.9 Type-9 records shall contain and be used to exchange minutiae or other friction ridge feature data. Each record shall represent the processed (automated and/or manual) image data from which upported

M Type4_Con tents

M Type5 Uns upported

M Type6_Uns upported

M Type7_Con tents

\section{Type3 Uns}

$<$ The test assertions are included under field testing for Record Type-3: DEPRECATED.>

$<$ The test assertions are included under field testing for Record Type-4: Grayscale fingerprint image.>

$<$ The test assertions are included under field testing for Record Type-5: DEPRECATED.>

$<$ The test assertions are included under field testing for Record Type-6: DEPRECATED.>

$<$ The test assertions for this type may not be supported in this version of the CTM. If they are supported, they are included under field testing or Record Type-7: User-defined image record .>

M Type8_Con tents

M Type9_Con tents

$<$ The test assertions for this type may not be supported in this version of the CTM. If they are supported, they are included under field testing for Record Type-9: Minutiae data record .>

$<$ The test assertions for this type may not be supported in this version of the CTM. If they are supported, they are included under field testing for Record Type-8: Signature image record.>

\section{$\mathrm{t}-2$}

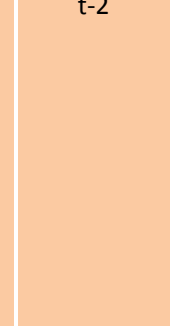

$\mathrm{t}-2$

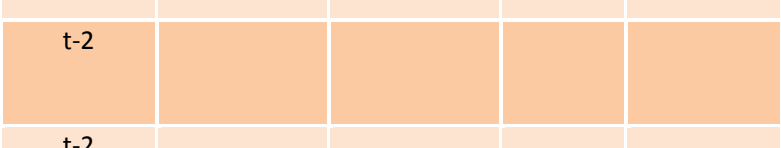

$\mathrm{t}-2$

$t-2$

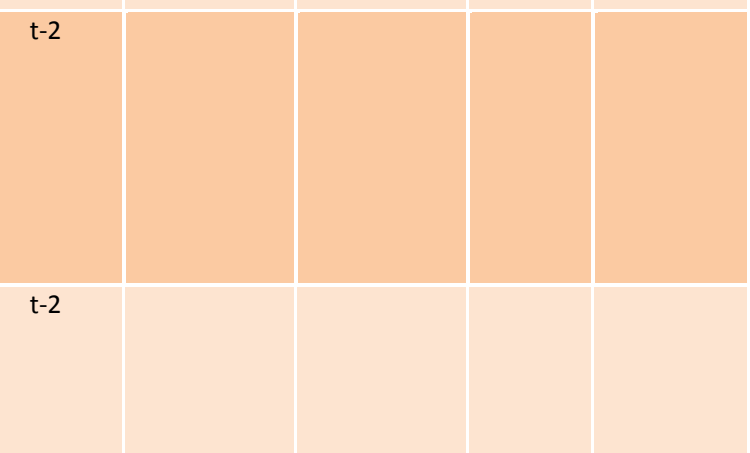




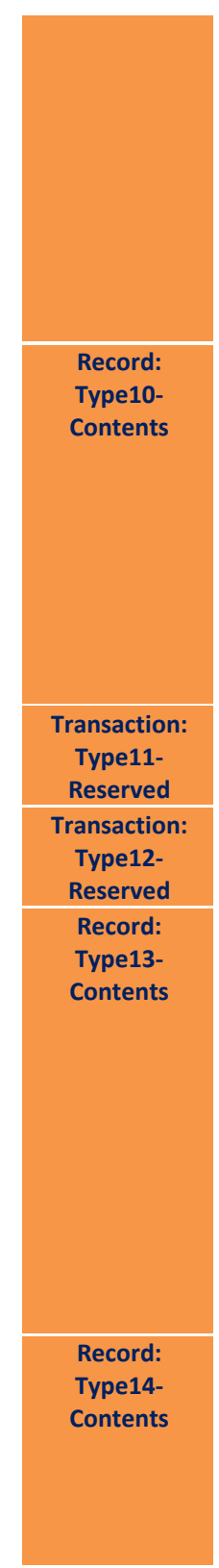

the characteristics are stated. The primary use of this record type shall be for remote searching of latent prints. New to this version of the standard is the Extended Feature Set

(EFS) for latent print markups. There is

also a capability to have additional

vendor-specified feature sets.

Workstation logs may also now be

transmitted in this record type.

5.3.10, Type-10 image records shall contain and

Table be used to exchange textual and image data from the face, scars, marks, and

tattoos (SMT). New to this version of the standard is the extension of the record type to handle images of other body parts. See Table 54 for a list of the images types possible in a Type-10 record.

Textual and analytic information

pertinent to the digitized image is also

contained in this record type.

5.3.11 Type-11 records are reserved for future use.

5.3.12 $\quad$ Type-12 records are reserved for future use.

5.3.13 Type-13 image records shall contain and be used to exchange variable-resolution latent friction ridge image data

(fingerprint, palmprint and/or plantar)

together with fixed and user defined

textual information fields pertinent to the digitized image. In all cases, the scanning resolution for latent images shall be at least $39.37 \mathrm{ppmm}$ (1000 ppi). The variable resolution latent image data contained in the Type- 13 record shall be uncompressed or may be the output from a lossless compression algorithm.

5.3.14 Type-14 image records shall contain fingerprint image data. It should be noted that as the resolution is increased, more detailed ridge and structure information becomes available in the fingerprint image. However, in all cases the scanning resolution class shall be at least 19.69

\section{Type10_Co}

ntents testing for Record Type-10: Facial, other bod part and SMT image record.>

ee Requirement ID “Transaction: Reserved Records">

$<$ See Requirement ID “Transaction: Reserved Records" $>$

M Type13_Co < The test assertions are included under field ntents testing for Record Type-13: Friction-ridge laten image record . >

M Type14_Co ntents
$<$ The test assertions are included under field testing for Record Type-14: Fingerprint image record.> $\mathrm{t}-2$

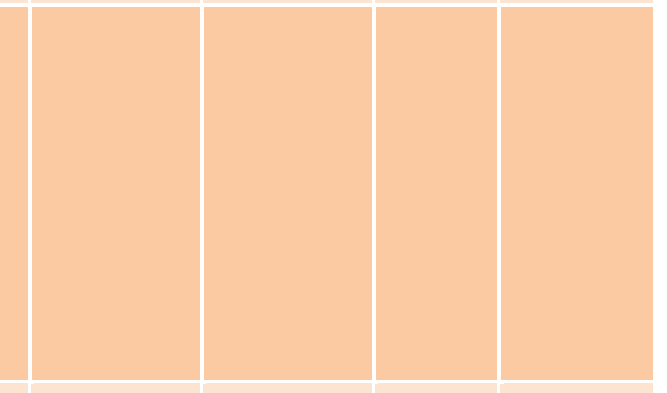

$\mathrm{t}-2$

$\mathrm{t}-2$

t-2

$(20)$




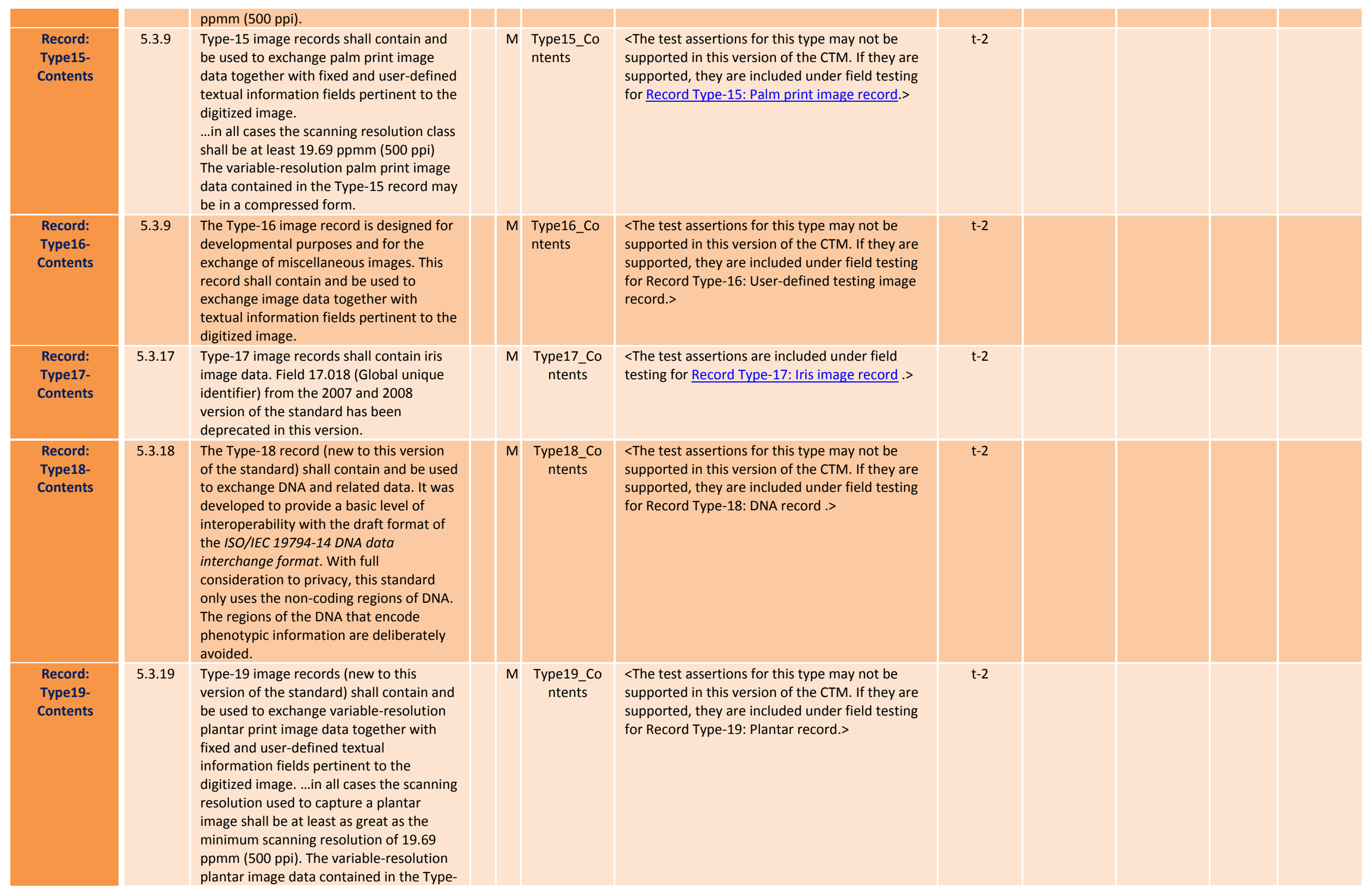




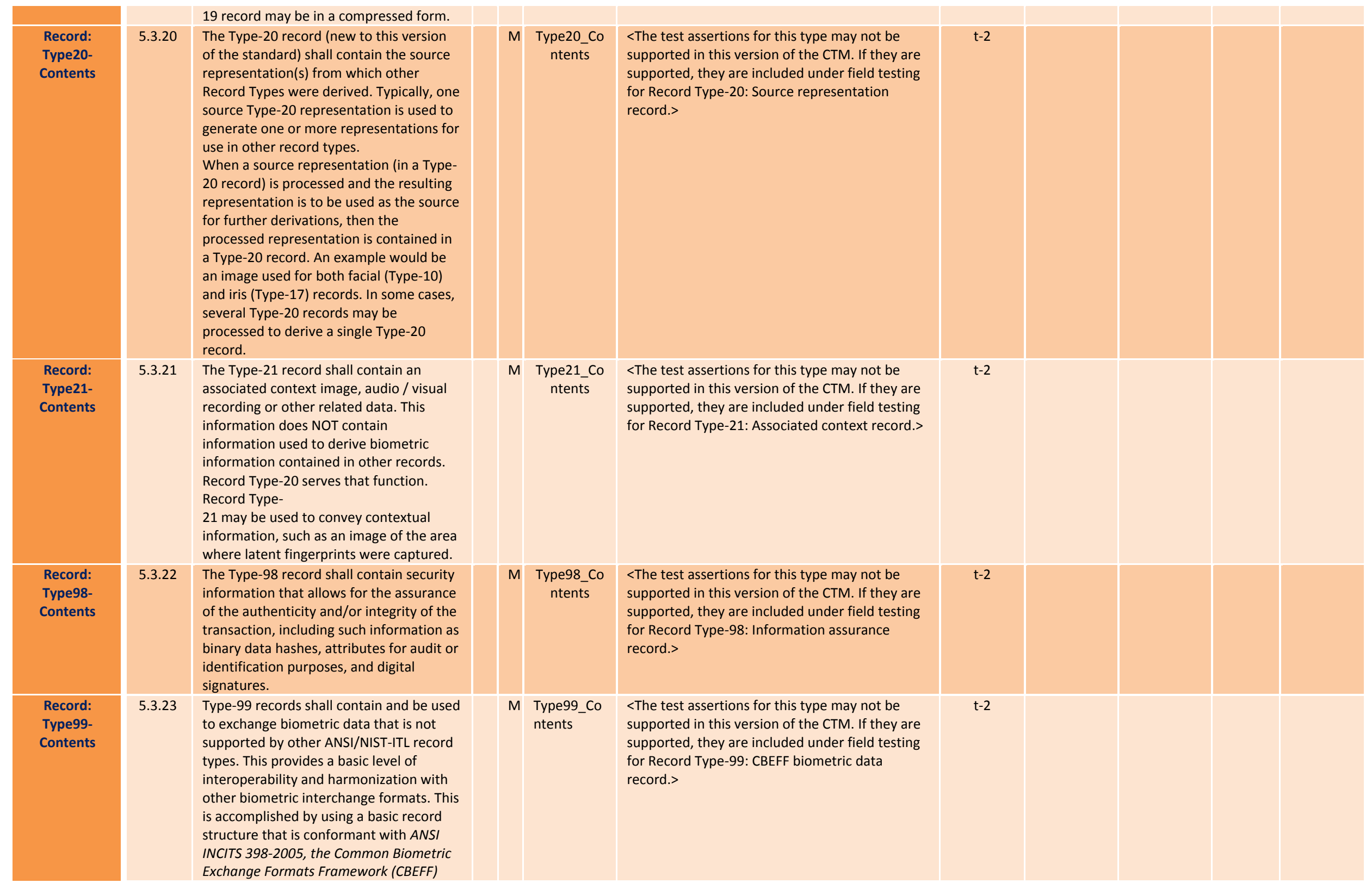




\begin{tabular}{|c|c|c|c|c|c|c|c|c|}
\hline & & $\begin{array}{l}\text { and a biometric data block specification } \\
\text { registered with the International } \\
\text { Biometrics Industry Association (IBIA). }\end{array}$ & & & & & & \\
\hline \multirow[t]{2}{*}{$\begin{array}{l}\text { Record: } \\
\text { Type1-ASCII }\end{array}$} & $\begin{array}{l}5.6 \\
\text { Table } \\
90\end{array}$ & $\begin{array}{l}\text { Record Type- } 1 \text { shall always be recorded in } \\
\text { all encodings using the 7-bit American } \\
\text { National Standard Code for Information } \\
\text { Interchange (ASCII). The eighth (leftmost) } \\
\text { bit shall contain a zero value. }\end{array}$ & 1 & M & $\begin{array}{l}\text { Type-1- } \\
\text { ASCII }\end{array}$ & $\begin{array}{l}\text { ForEach(Field in Record ST Type(Record) EQ 1) } \\
\{ \\
\text { \{Bytes(Field)\} MO [0x02, 0x03, 0x1C to 0x7E] } \\
\}\end{array}$ & & $\mathrm{T}$ \\
\hline & C. 4.1 & $\begin{array}{l}\text { For compatibility with existing } \\
\text { implementations of the standard, } \\
\text { implementers may wish to limit content } \\
\text { to the } 128 \text { characters that can be } \\
\text { represented by 7-bit ASCII. } \\
\text { Nevertheless, senders and receivers of } \\
\text { XML packages using this standard may } \\
\text { agree on other character sets, including } \\
\text { international character sets. }\end{array}$ & 1 & M & $\begin{array}{l}\text { NIEM- } \\
\text { Type1-User } \\
\text { Defined }\end{array}$ & TRUE & $\mathrm{t}-4$ & $x$ \\
\hline $\begin{array}{l}\text { Transaction: } \\
\text { Encoding- } \\
\text { Base64 }\end{array}$ & 5.6 & $\begin{array}{l}\text { Base- } 64 \text { shall be used for converting non- } \\
\text { ASCII text into ASCII form, where required } \\
\text { and noted in the standard. }\end{array}$ & 1 & $M$ & $\begin{array}{l}\text { Data- } \\
\text { Encoding- } \\
\text { Base-64 }\end{array}$ & $<$ Not tested. $>$ & $\mathrm{t}-4$ & B \\
\hline $\begin{array}{l}\text { Field: } \\
\text { Encoding- } \\
\text { CharSets }\end{array}$ & $\begin{array}{l}5.6, \\
\text { Table } 2\end{array}$ & $\begin{array}{l}\text { Field } 1.015 \text { Character encoding/DCS is an } \\
\text { optional field that allows the user to } \\
\text { specify an alternate character encoding... } \\
\text { Field } 1.015 \text { Character encoding/DCS } \\
\text { contains three information items: the } \\
\text { character encoding set index/ CSI, the } \\
\text { character encoding sent name/CSN, and } \\
\text { the character encoding set version/CSV. } \\
\text { The first two items are selected from the } \\
\text { appropriate columns of Table } 2 \text {. }\end{array}$ & 3 & 0 & $\begin{array}{l}\text { Data- } \\
\text { Encoding- } \\
\text { CharSets }\end{array}$ & $<$ Not tested.> & $\mathrm{t}-4$ & B \\
\hline
\end{tabular}


Table C.2 - Assertions for Implementation Domain \& Application Profiles

\begin{tabular}{|c|c|c|c|c|c|c|c|c|c|c|c|}
\hline $\begin{array}{c}\text { Requireme } \\
\text { nt } \\
\text { ID }\end{array}$ & $\begin{array}{c}\text { Referen } \\
\text { ce in } \\
\text { Base } \\
\text { Standar } \\
\text { d }\end{array}$ & $\begin{array}{l}\text { Requirement } \\
\text { Summary }\end{array}$ & $\begin{array}{l}\text { L } \\
\text { e } \\
\text { v } \\
\text { e } \\
\text { I }\end{array}$ & $\begin{array}{l}\mathrm{s} \\
\mathrm{t} \\
\mathrm{a} \\
\mathrm{t} \\
\mathrm{u} \\
\mathrm{s}\end{array}$ & $\begin{array}{l}\text { Assertion } \\
\text { ID }\end{array}$ & $\begin{array}{l}\text { Test } \\
\text { Assertion }\end{array}$ & $\begin{array}{l}\text { Test } \\
\text { Note }\end{array}$ & $\begin{array}{l}\text { Implemen } \\
\text { tation } \\
\text { Support }\end{array}$ & $\begin{array}{l}\text { Supporte } \\
\text { d Range }\end{array}$ & $\begin{array}{c}\text { Test } \\
\text { Result }\end{array}$ & $\begin{array}{c}\text { Applicab } \\
\text { ility }\end{array}$ \\
\hline \multicolumn{12}{|c|}{ 6: Implementation Domain and Application Profiles } \\
\hline $\begin{array}{l}\text { Field: } \\
\text { Domain }\end{array}$ & 6 & $\begin{array}{l}\text { An implementation domain, coded in } \\
\text { Field } 1.013 \text { Domain name / DOM of a } \\
\text { Type-1 record as an optional field, is a } \\
\text { group of agencies or organizations that } \\
\text { have agreed to use preassigned data } \\
\text { fields with specific meanings (typically in } \\
\text { Record Type-2) for exchanging } \\
\text { information unique to their installations. } \\
\text { The implementation domain is usually } \\
\text { understood to be the primary application } \\
\text { profile of the standard. }\end{array}$ & 3 & 0 & $\begin{array}{l}\text { Fields- } \\
\text { Domain }\end{array}$ & $<$ Not tested.> & $t-3$ & & & & B \\
\hline Field: APS & 6 & $\begin{array}{l}\text { Field } 1.016 \text { Application profile } \\
\text { specifications / APS allows multiple } \\
\text { application profiles to be referenced. The } \\
\text { organization responsible for the profile, } \\
\text { the profile name and its version are all } \\
\text { mandatory for each application profile } \\
\text { specified. A transaction must conform to } \\
\text { each profile that is included in this field. }\end{array}$ & 3 & 0 & Fields-APS & $<$ Not tested.> & $t-3$ & & & & B \\
\hline
\end{tabular}


Table C.3 - Assertions for Information Associated with Several Records

\begin{tabular}{|c|c|c|c|c|c|c|c|c|c|c|c|}
\hline $\begin{array}{l}\text { Requireme } \\
\text { nt } \\
\text { ID }\end{array}$ & $\begin{array}{l}\text { Referen } \\
\text { ce in } \\
\text { Base } \\
\text { Standar } \\
\quad \text { d }\end{array}$ & $\begin{array}{l}\text { Requirement } \\
\text { Summary }\end{array}$ & $\begin{array}{l}\text { L } \\
\text { e } \\
\text { v } \\
\text { e } \\
\text { I }\end{array}$ & $\begin{array}{l}\mathrm{s} \\
\mathrm{t} \\
\mathrm{a} \\
\mathrm{t} \\
\mathrm{u} \\
\mathrm{s}\end{array}$ & $\begin{array}{l}\text { Assertion } \\
\text { ID }\end{array}$ & $\begin{array}{l}\text { Test } \\
\text { Assertion }\end{array}$ & $\begin{array}{l}\text { Test } \\
\text { Note }\end{array}$ & $\begin{array}{l}\text { Implemen } \\
\text { tation } \\
\text { Support }\end{array}$ & $\begin{array}{l}\text { Supporte } \\
\text { d Range }\end{array}$ & $\begin{array}{c}\text { Test } \\
\text { Result }\end{array}$ & $\begin{array}{c}\text { Applicab } \\
\text { ility }\end{array}$ \\
\hline \multicolumn{12}{|c|}{ 7: Information Associated with Several Records } \\
\hline \multirow[t]{4}{*}{$\begin{array}{l}\text { Field: } \\
\text { xx.001- } \\
\text { Record } \\
\text { Header }\end{array}$} & \multirow[t]{3}{*}{7.1} & \multirow{3}{*}{$\begin{array}{l}\text { The record header appears as the first } \\
\text { field (xx.001) in each Record Type. It } \\
\text { contains information particular to the } \\
\text { encoding format chosen, in order to } \\
\text { enable proper reading of the record. In } \\
\text { Traditional encoding, this field contains } \\
\text { the record length in bytes (including all } \\
\text { information separators). }\end{array}$} & 1 & M & xx.001-First & $\begin{array}{l}\text { ForEach(Record in Transaction ST Type(Record) } \\
\text { NEQ } 4 \text { OR 8) } \\
\{ \\
\text { FieldNumber(First(Field in Record)) EQ } 1 \\
\}\end{array}$ & & & & & $\mathrm{T}$ \\
\hline & & & 1 & M & $\begin{array}{l}\text { NIEM- } \\
\text { RecordCate } \\
\text { gory-First }\end{array}$ & $\begin{array}{l}\text { ForEach(Record in Transaction) } \\
\{ \\
\text { First(Field in Record) EQ } \\
\text { XElm(<biom:RecordCategoryCode }>\text { ) } \\
\}\end{array}$ & & & & & $x$ \\
\hline & & & 1 & M & $\begin{array}{l}\text { xx.001- } \\
\text { Record } \\
\text { Header }\end{array}$ & $\begin{array}{l}\text { ForEach(Record in Transaction) } \\
\{ \\
\{\text { Record.001\} EQ Length (Record) } \\
\}\end{array}$ & & & & & $\mathrm{T}$ \\
\hline & $\begin{array}{c}\text { C.5.7, } \\
7.1\end{array}$ & $\begin{array}{l}\text { Record Length. There is no corresponding } \\
\text { XML element. See Section 7.1. } \\
\text { In NIEM-conformant XML encoding, this } \\
\text { field contains the RecordCategoryCode, } \\
\text { which is the numeric representation of } \\
\text { the Record Type. }\end{array}$ & 1 & M & $\begin{array}{l}\text { NIEM- } \\
\text { xx.001- } \\
\text { Record } \\
\text { Category }\end{array}$ & $\begin{array}{l}<\text { These assertions are included under field } \\
\text { testing for the associated record types.> }\end{array}$ & $t-2$ & & & & \\
\hline \multirow{3}{*}{$\begin{array}{l}\text { Field: } \\
\text { xx.999- } \\
\text { Reserved }\end{array}$} & \multirow[t]{3}{*}{7.2} & \multirow{3}{*}{$\begin{array}{l}\text { Field xx.999 is reserved in Record Types } \\
10 \text { and above for data associated with the } \\
\text { record that is described in the other fields } \\
\text { of the record. It is mandatory in most of } \\
\text { these record types (It does not appear in } \\
\text { Type-18 or Type-98). }\end{array}$} & & M & $\begin{array}{l}\text { xx.999- } \\
\text { Reserved }\end{array}$ & $\begin{array}{l}<\text { These assertions are included under field } \\
\text { testing for the associated record types.> }\end{array}$ & $t-2$ & & & & \\
\hline & & & 1 & M & $\begin{array}{c}\text { xx.999- } \\
\text { RecordType } \\
\text { s }\end{array}$ & $\begin{array}{l}\text { ForEach(Field ST FieldNumber(Field) EQ 999) } \\
\{ \\
\text { Type(ParentRecord(Field)) GTE } 10 \text { AND NOT MO } \\
{[18,98]} \\
\{\end{array}$ & & & & & $\mathrm{T}$ \\
\hline & & & 1 & M & NIEM- & ForEach(Field ST Field EQ & & & & & $x$ \\
\hline
\end{tabular}



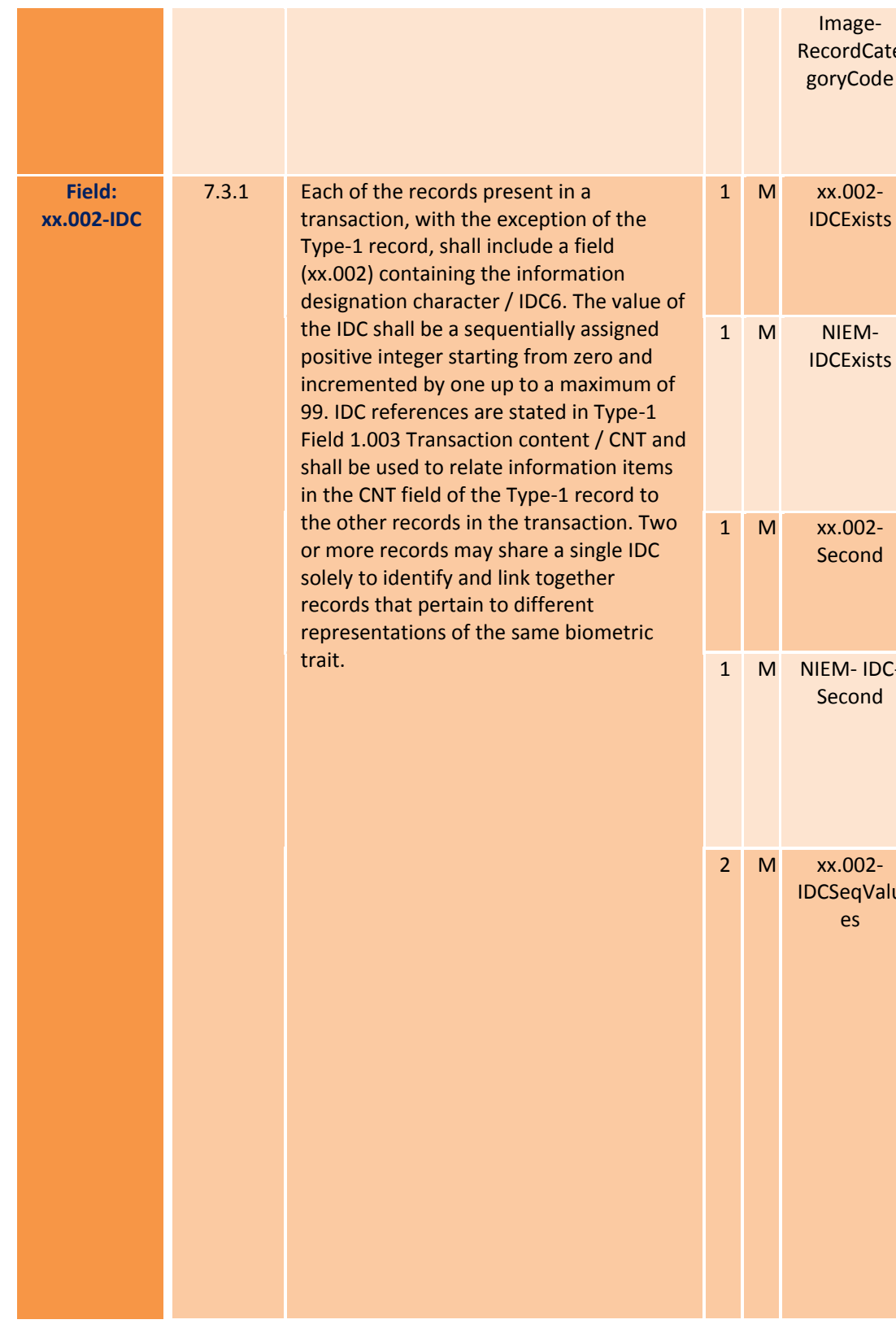

XEIm(nc:BinaryBase64Object))

\{XElm(biom:RecordCategoryCode) in

ParentRecord(Field)\} GTE 10 AND NOT MO [18,

98]

ForEach( Record ST Type(Record) NEQ 1)

\{

resent(Record.002)

\}

ForEach(Record ST Record NEQ

XEIm(itl:PackagelnformationRecord))

Present(XEIm(biom:ImageReferenceldentificatio

ForEach( Record ST Type(Record) NEQ 4 OR 8)

\{

FieldNumber(Second(Field in Record)) EQ 2

\}

ForEach(Record ST Record NEQ

XEIm(itl:PackagelnformationRecord))

Second(Field in Record) EQ

XEIm(biom:ImageReferenceldentification)

\}

$\operatorname{Var}($ IDC_Fields)

All(Fields in

Records ST Type(Records) NEQ 1 AND

FieldNumber(Fields) EQ 2)

\{First(Field in IDC_Fields)\} EQ 0

AND

ForEach(Field in IDC_Fields)

\{

\{Field\} LTE 99 AND GTE 0

AND

$\{$ Next(Field)\} LTE <Current Maximum IDC Value $>$

$+1$ 


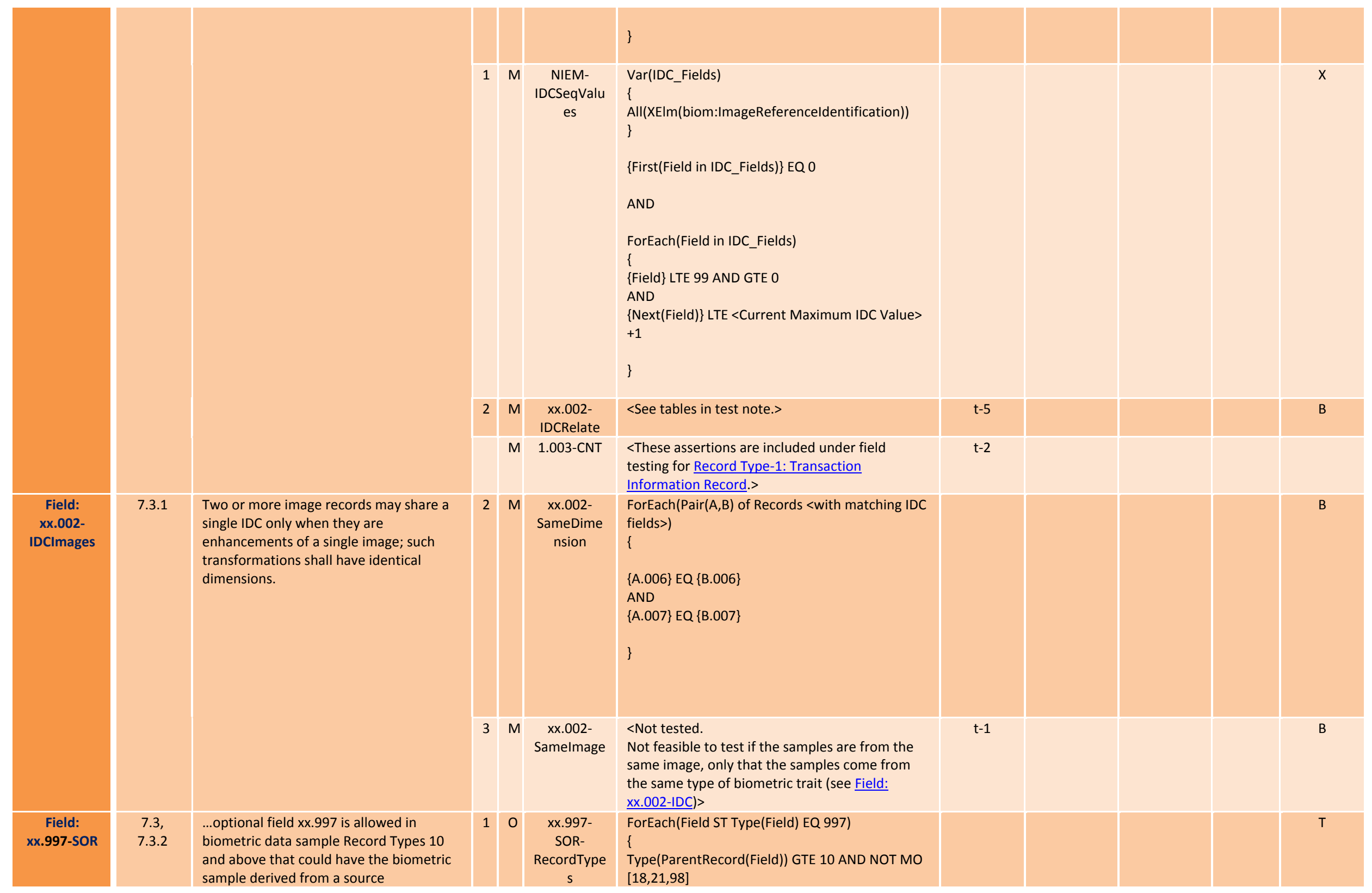




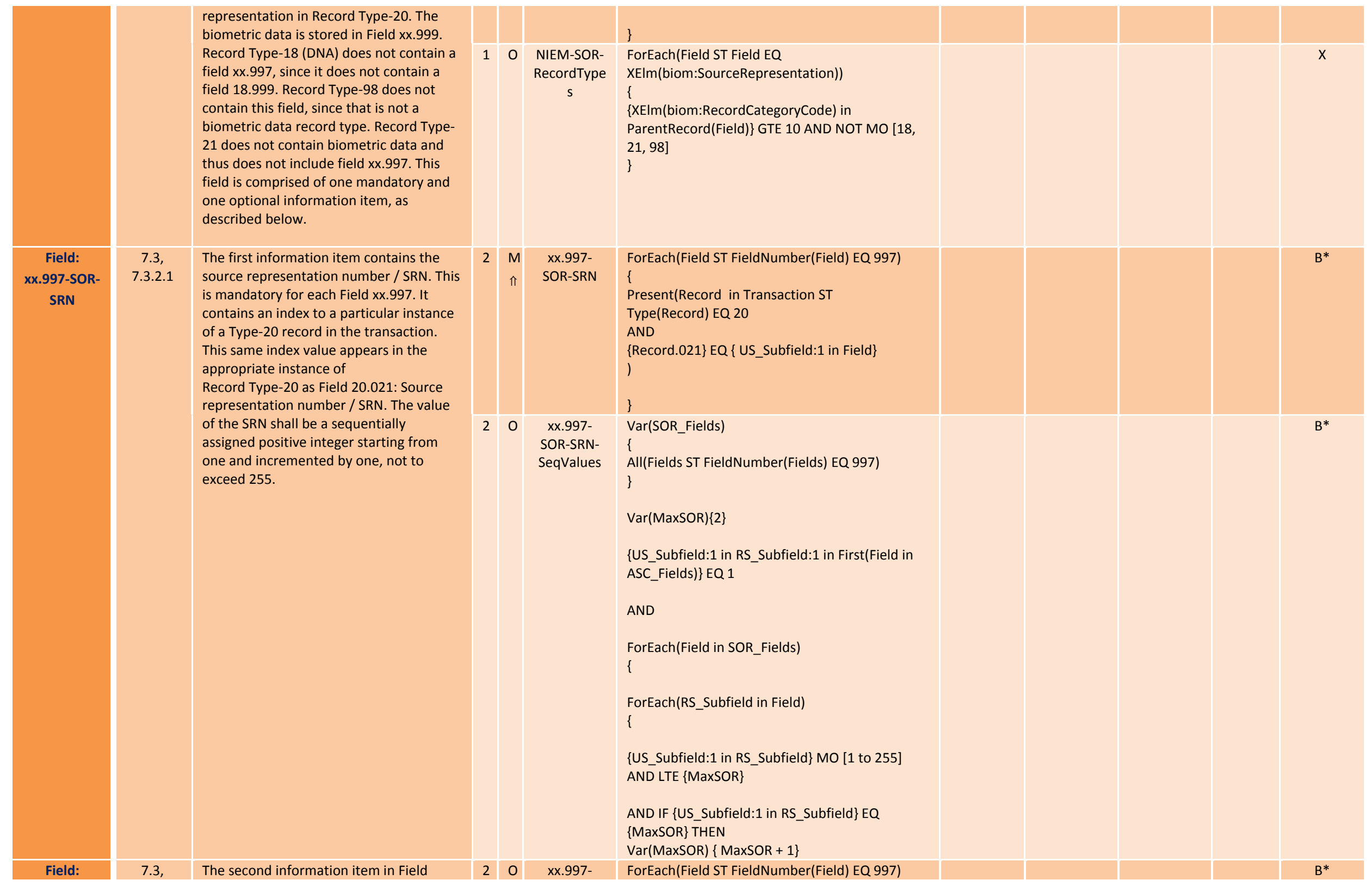




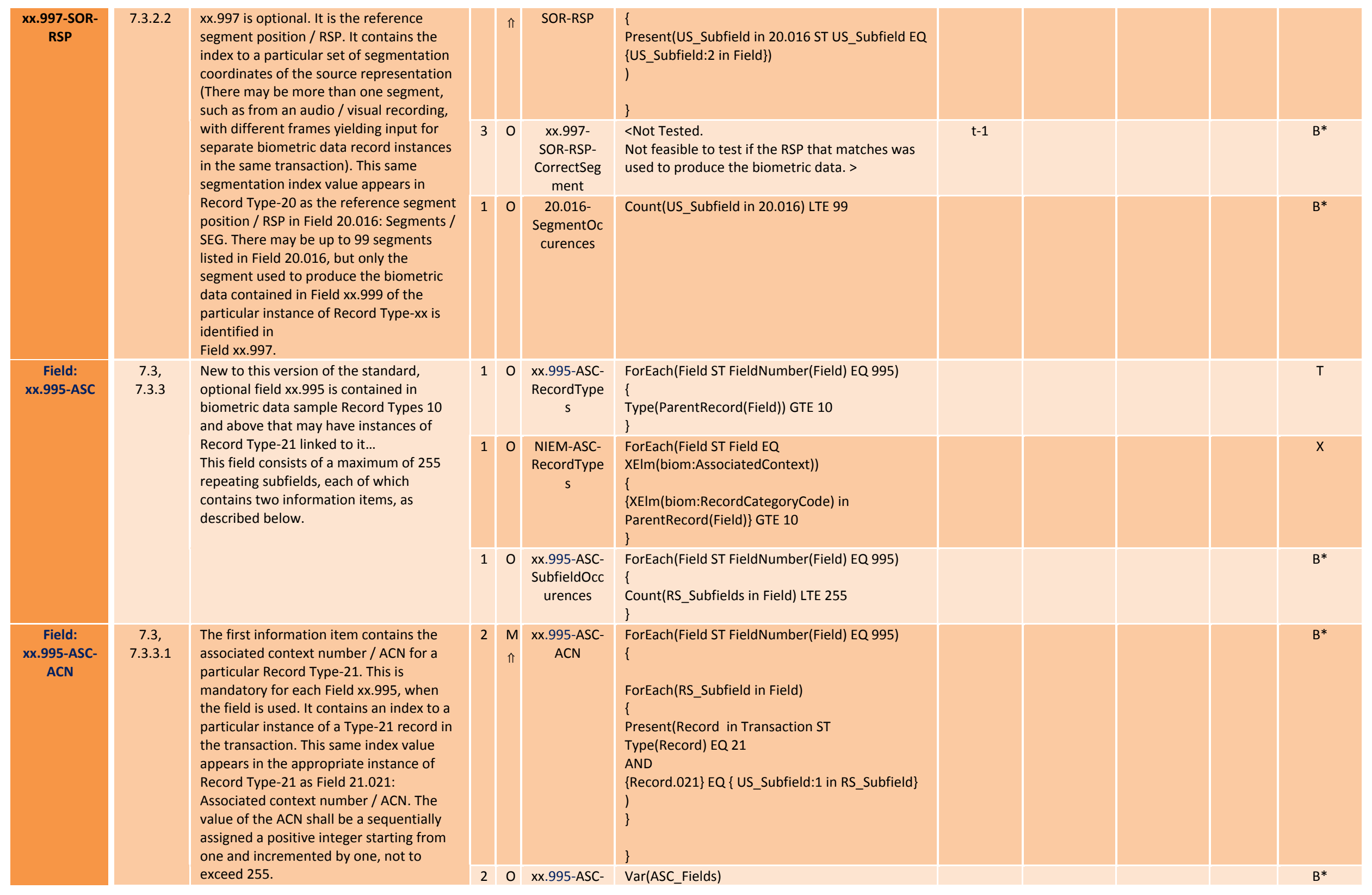




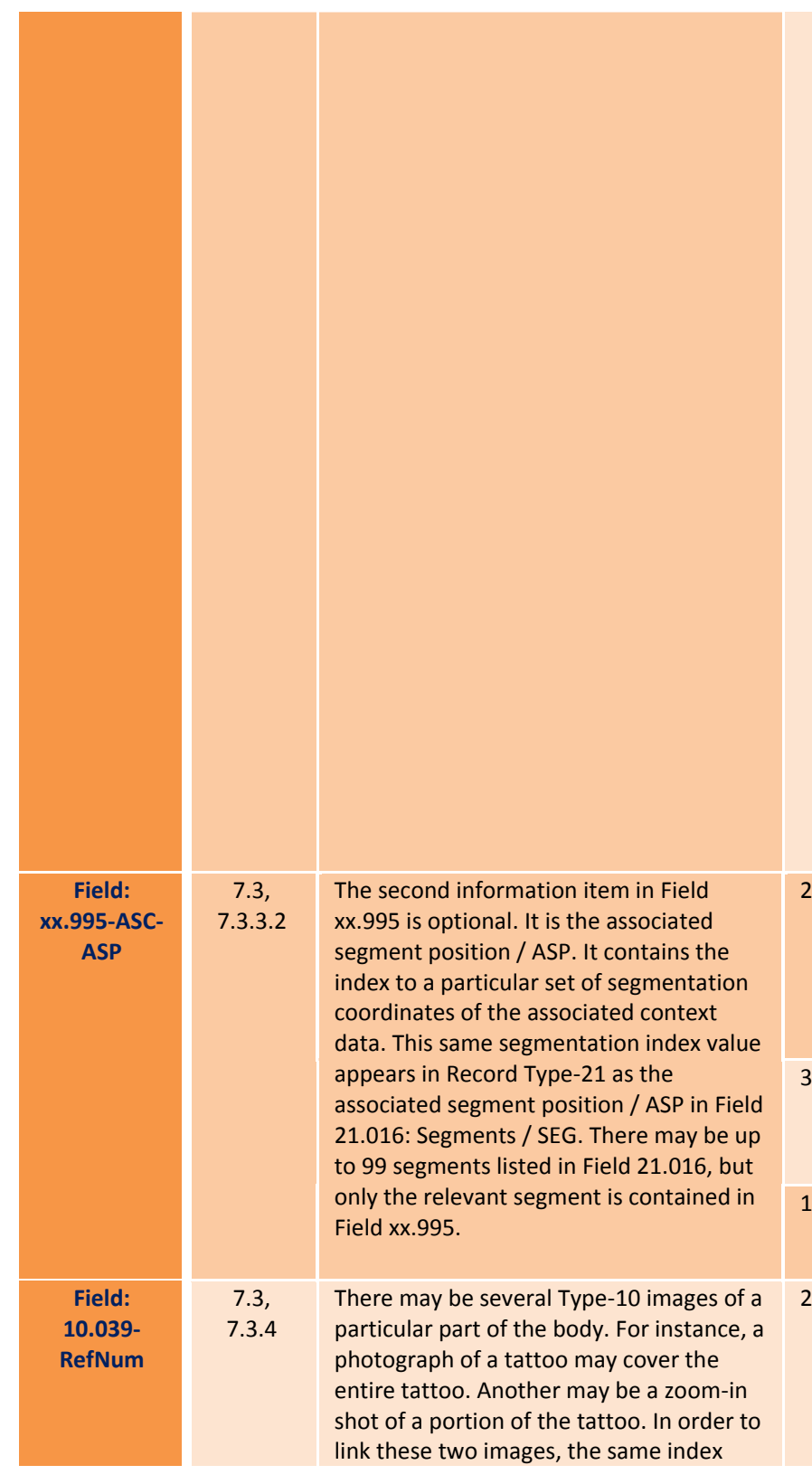

ACN-

SeqValues All(Fields in Transaction ST FieldNumber(Fields) EQ 995)

\}

$\operatorname{Var}(\operatorname{MaxASC})\{2\}$

\{US_Subfield:1 in RS_Subfield:1 in First(Field in ASC_Fields)\} EQ 1

AND

ForEach(Field in ASC_Fields)

\{

ForEach(RS_Subfield in Field)

\{

\{US_Subfield:1 in RS_Subfield\} MO [1 to 255] AND LTE \{MaxASC $\}$

AND IF $\{$ US_Subfield: 1 in RS_Subfield $\}$ EQ

$\{$ MaxASC $\}$ THEN

$\operatorname{Var}(\operatorname{MaxASC})\{$ MaxASC +1$\}$

\}
\}

\begin{tabular}{lll|l}
2 & $\mathrm{O}$ & $\mathrm{xx} .995-$ ASC- & ForEach(Field ST FieldNumber(Field) EQ 995)
\end{tabular} \begin{tabular}{|l|c|}
\hline$\Uparrow$ & AXP \\
\hline & ASP \\
\hline O & xx.995-ASC- \\
\hline
\end{tabular}

$\begin{array}{lr}0 & x x .995-A S C \\ \Uparrow & \text { ASP }\end{array}$

ASP-

ment

1 M $\begin{array}{r}21.016- \\ \text { SegmentO }\end{array}$

SegmentOc

curences

T10-DiffIDC

Present( US_Subfield in 20.016 ST US_Subfield EQ \{US_Subfield:2 in Field\})

)

$<$ Not Tested.

Not feasible to test if the ASP that matches is the

one that is relevant. >

Count(US_Subfield in 21.016) LTE 99

IF Count(Records ST Type(Records) EQ 10) GT 1

THEN

ForEach (Pair (A,B) of Records ST Type(Records)

EQ 10)

IF $\{$ A.039\} EQ $\{$ B.039\} 


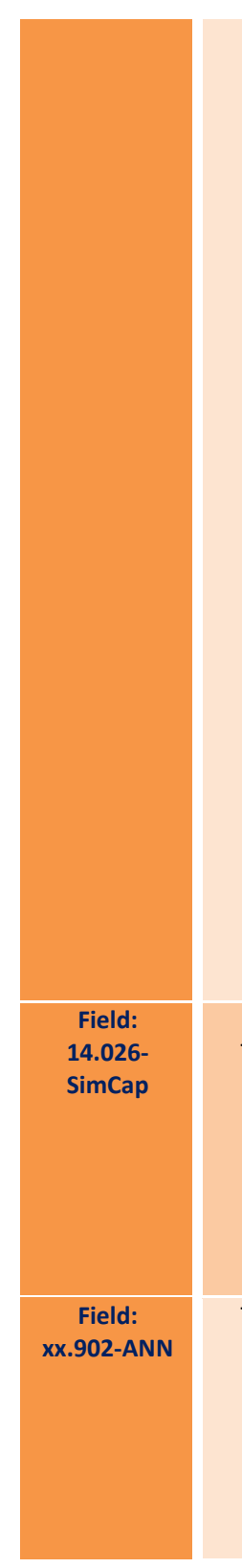

number is assigned to Field 10.039: Type10 reference number / T10, which is new to this version of the standard. Note that these images would have different IDC

values.

In order to accommodate the emergence of technology that can simultaneously capture fingerprint images on separate platens or other technology that does not preserve the full relative position of the fingers to each other, Field 14.026 :

Simultaneous capture / SCF allows the user to use the same index for all images that were simultaneously captured.

New for this version of the standard,

optional field xx.902 is used to store

annotation, logging, or processing

information associated with one or more processing algorithms or workstations. If present, this text field shall consist of one or more subfields comprised of a set of information items. 
Four mandatory information items

comprise a subfield:

- The first information item is the GMT

date and time / GMT when the processing

occurred. (See Section 7.7.2.2)

- The second information item

(processing algorithm name/version /

$\mathrm{NAV}$ ) shall contain an unformatted text

string of up to 64 characters identifying

the name and version of the processing

algorithm or workstation.

- The third information item (algorithm owner / OWN) shall contain a text string of up to 64 characters with the contact

information for the organization th

owns the processing algorithm or latent

workstation.

- The fourth and final information item (process description / PRO) shall contain an unformatted text string of up to 255

characters describing a process or

procedure applied to the sample in this Type-XX record.

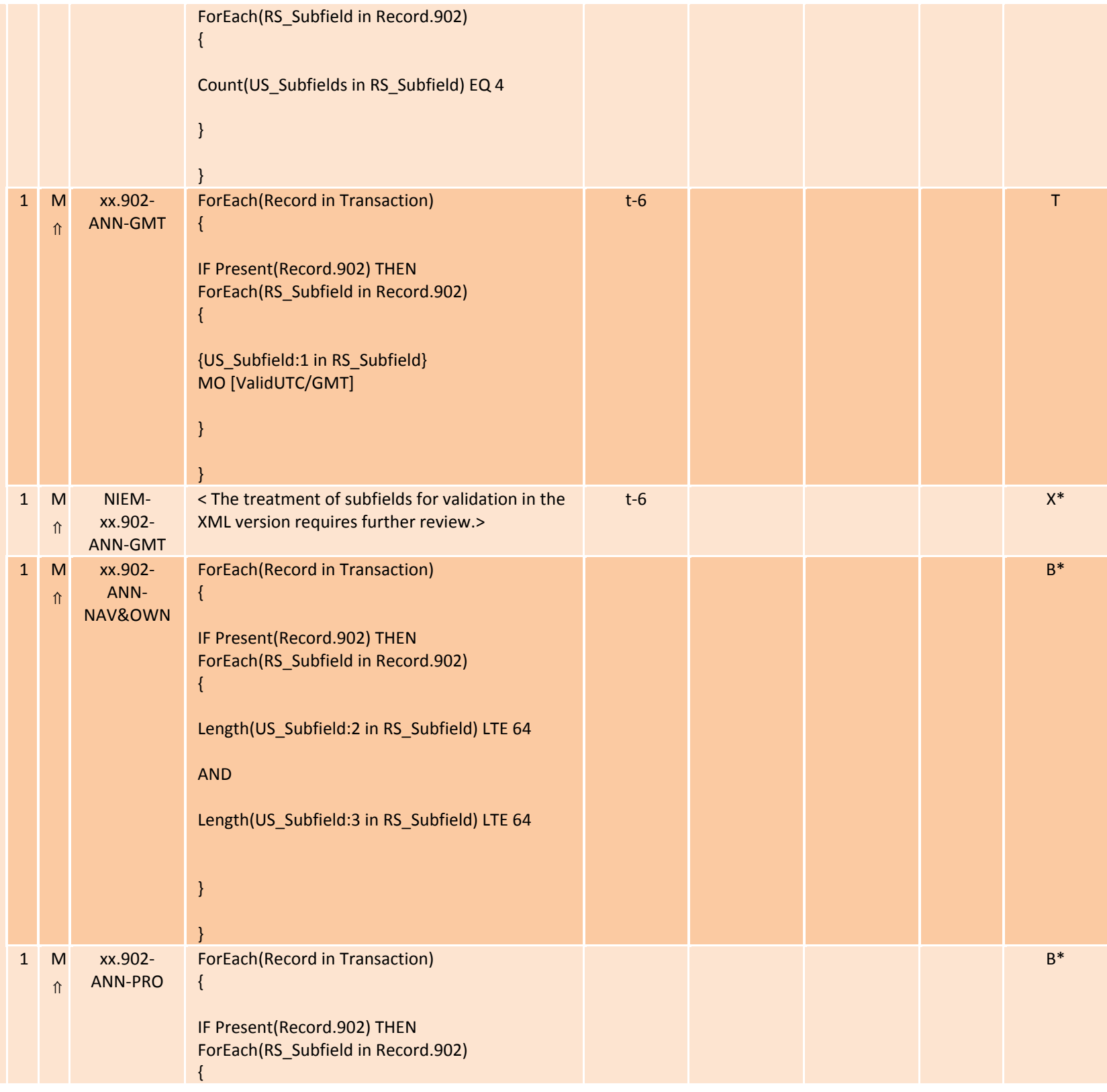




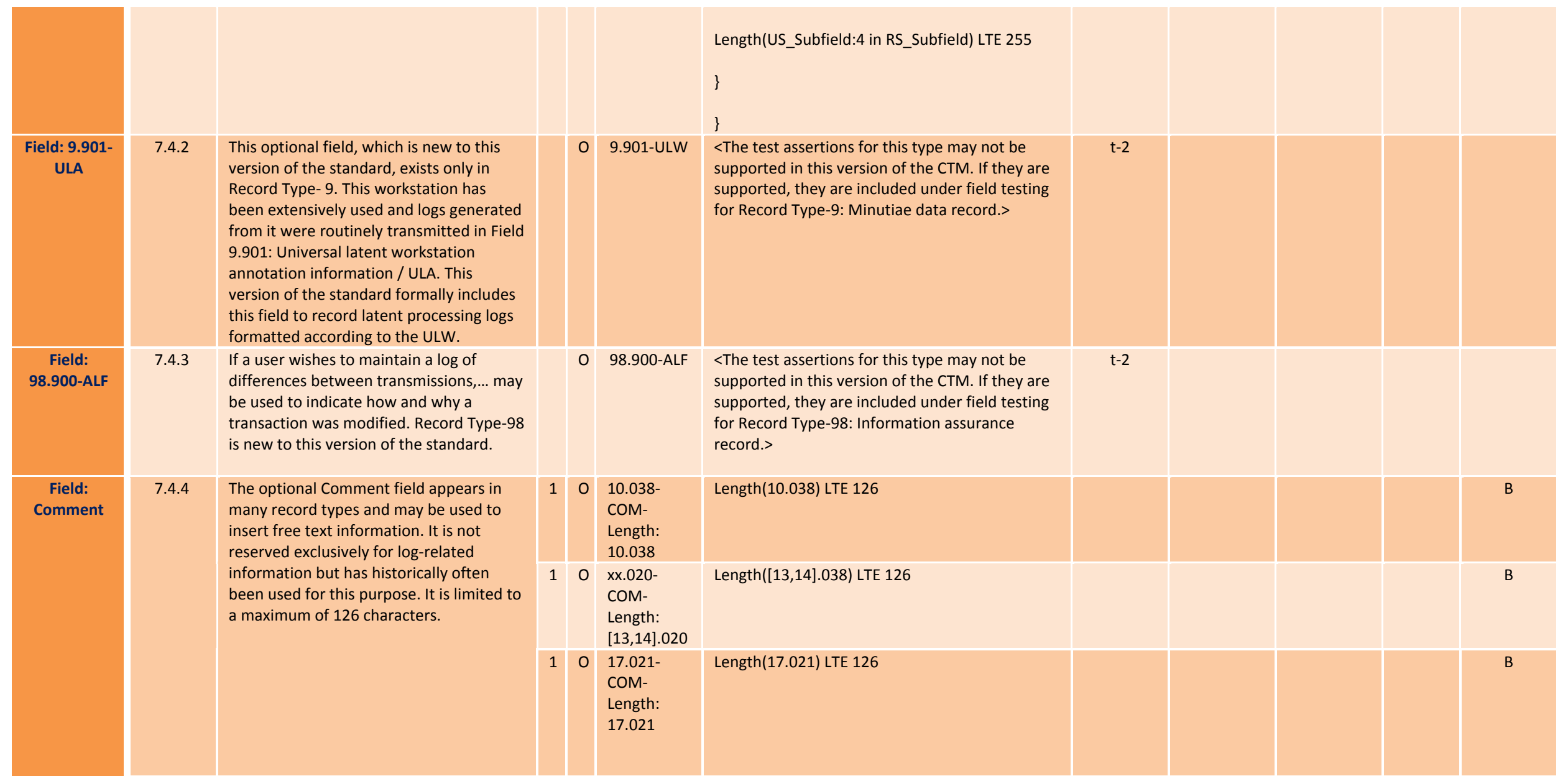




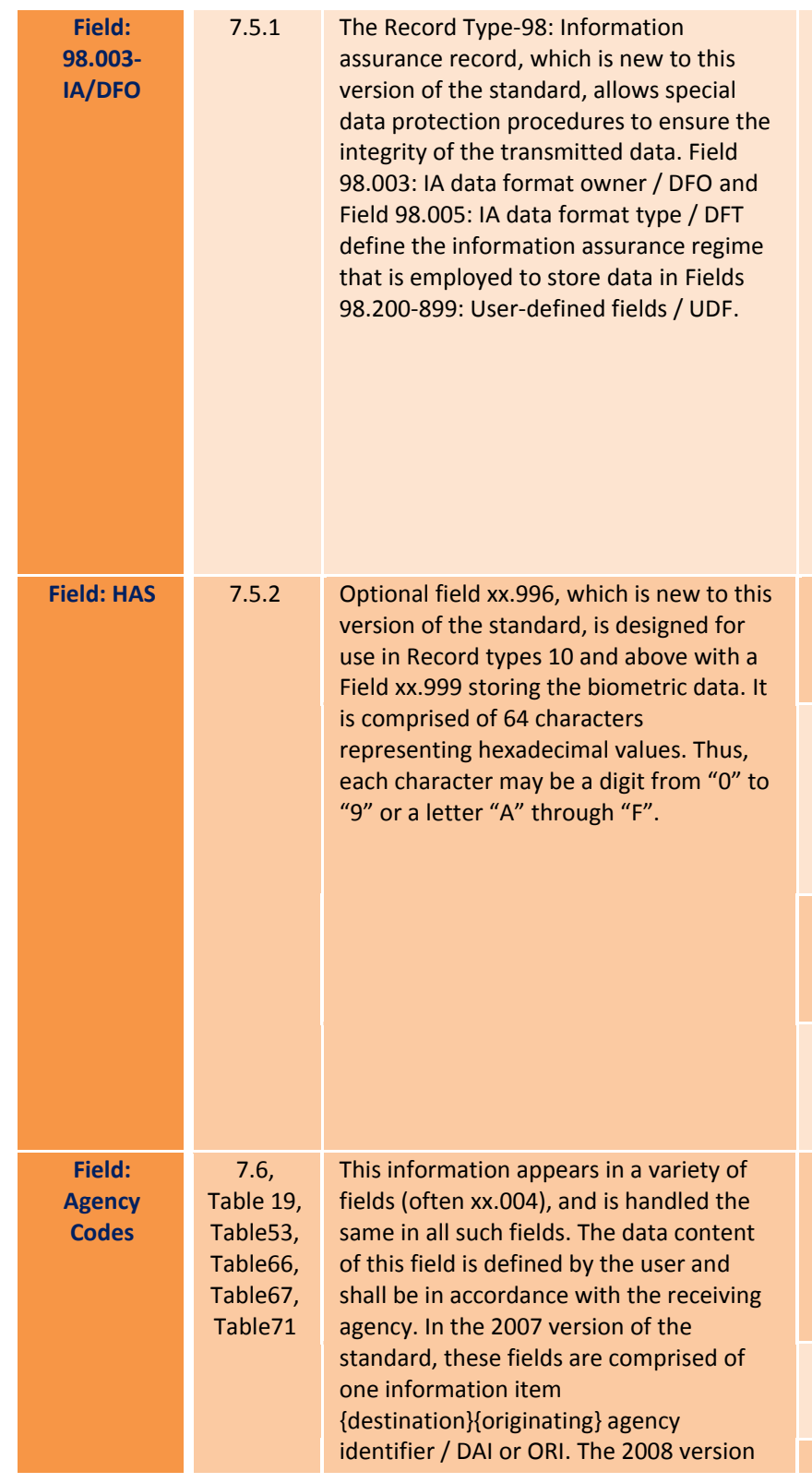

M 98.003-DFO

supported in this version of the CTM. If they are supported, they are included under field testing for Record Type-98: Information assurance record.>

\section{$10 \quad x x .996-$ HAS- RecordType}

O NIEM-HASRecordType

$$
\text { \{XEIm(biom:RecordCategoryCode) in }
$$

ParentRecord(Field)\} GTE 10

\begin{tabular}{c|c|c|}
\hline & Xx.996- \\
HAS-HEX
\end{tabular}

$10 \quad x \times 996-$ HAS-Length ForEach(Field ST FieldNumber(Field) EQ 996) Len ForEach(Field ST Field EQ

XElm(biom:ImageHashValue) rEach(Field ST FieldNumber(Field) EQ 996)

ForEach(Field ST FieldNumber(Field) EQ 996)
$\begin{aligned} & \{ \\ & \text { Type(ParentRecord(Field)) GTE } 10\end{aligned}$
\}

$1 \quad \mathrm{M} \quad \begin{gathered}1.007- \\ \text { DAI/ORI- }\end{gathered}$

Length

1 M 1.008-

Length

1 M [10,13,14,1 Length(US_Subfield:1 in [10,13,14,15,17].004)

$\mathrm{t}-2$

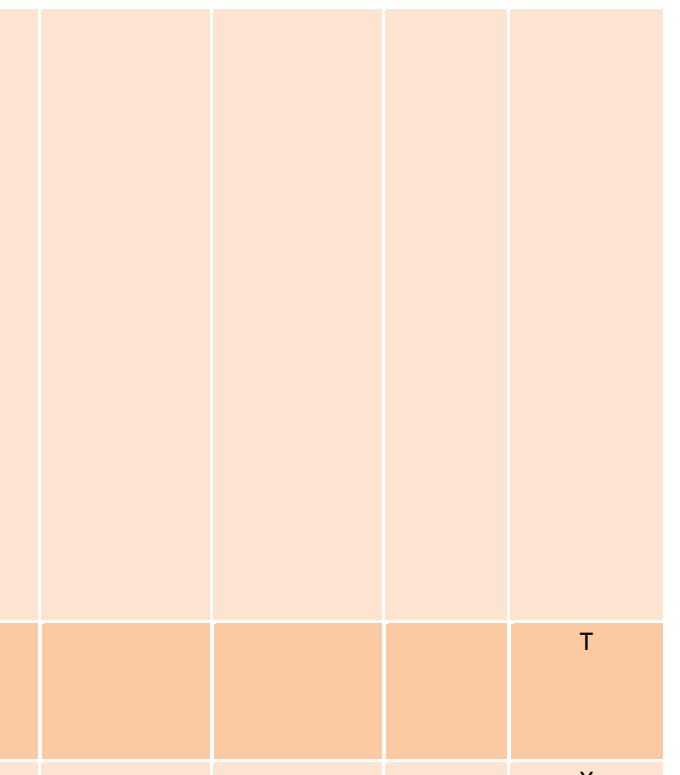

Length(US_Subfield:1 in 1.007) GTE 1

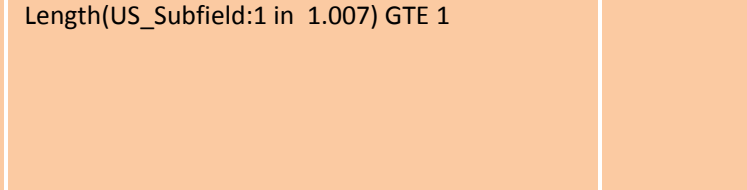

ngth(US_Subfield:1 in 1.008) GTE 1 


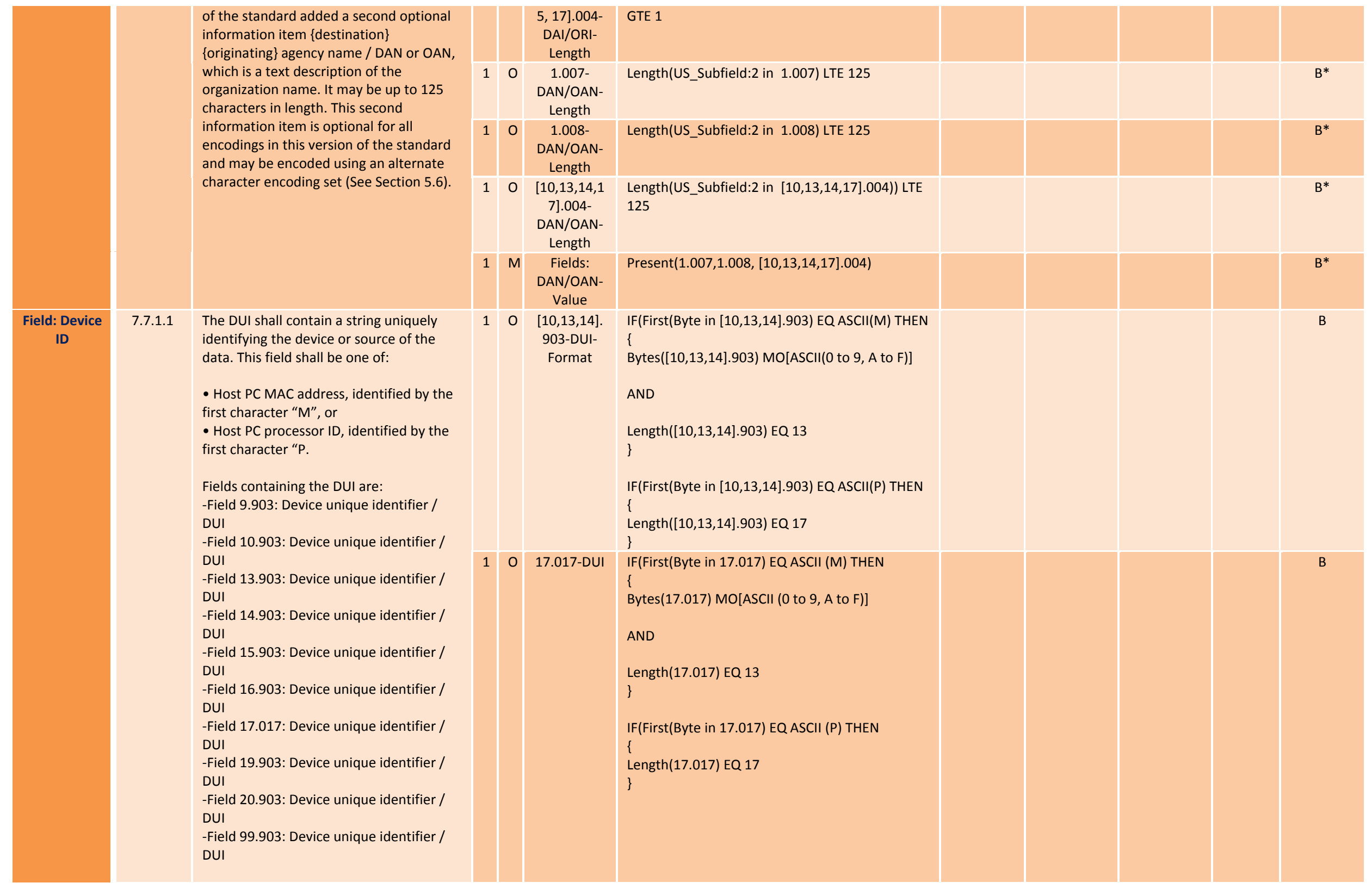




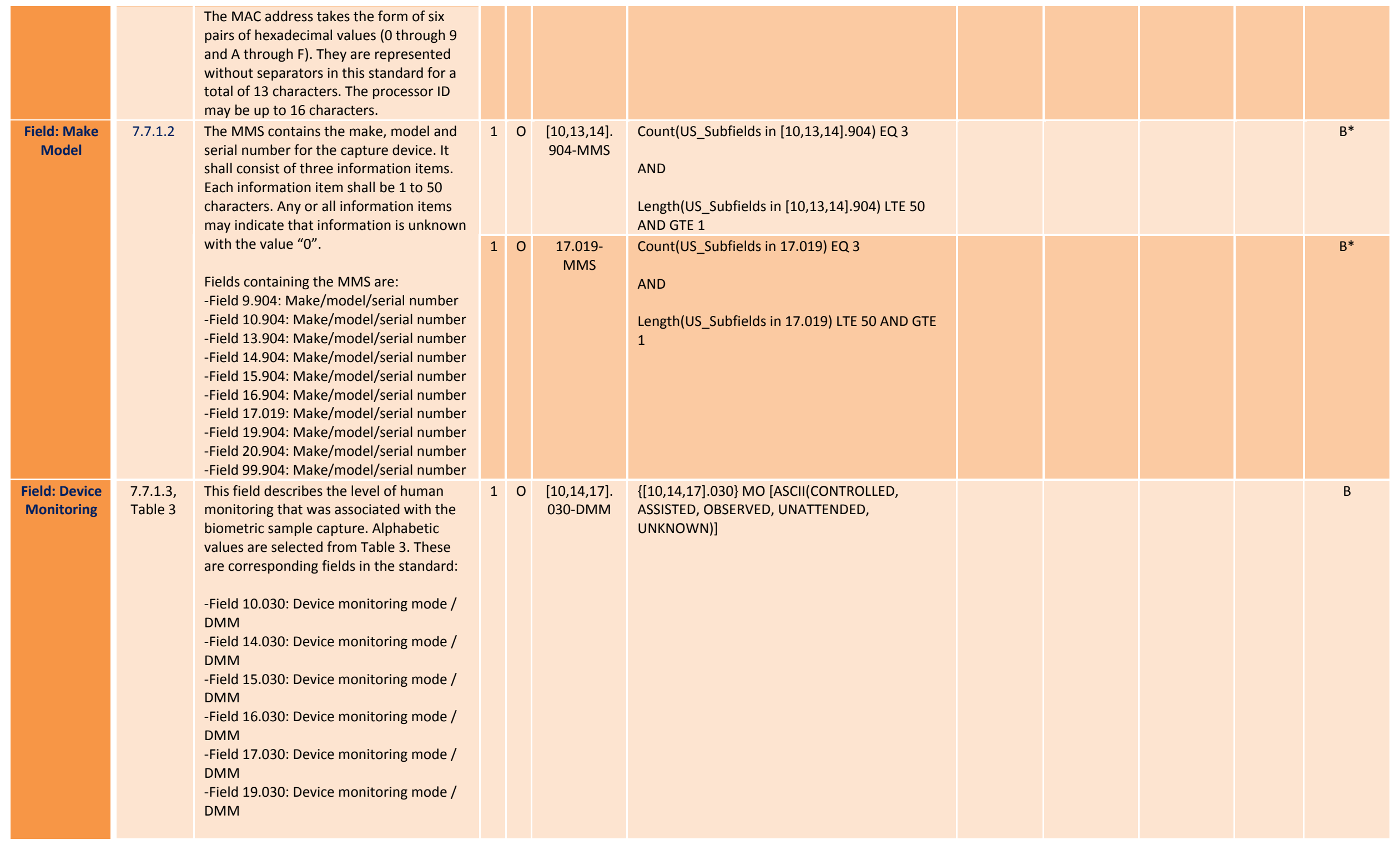




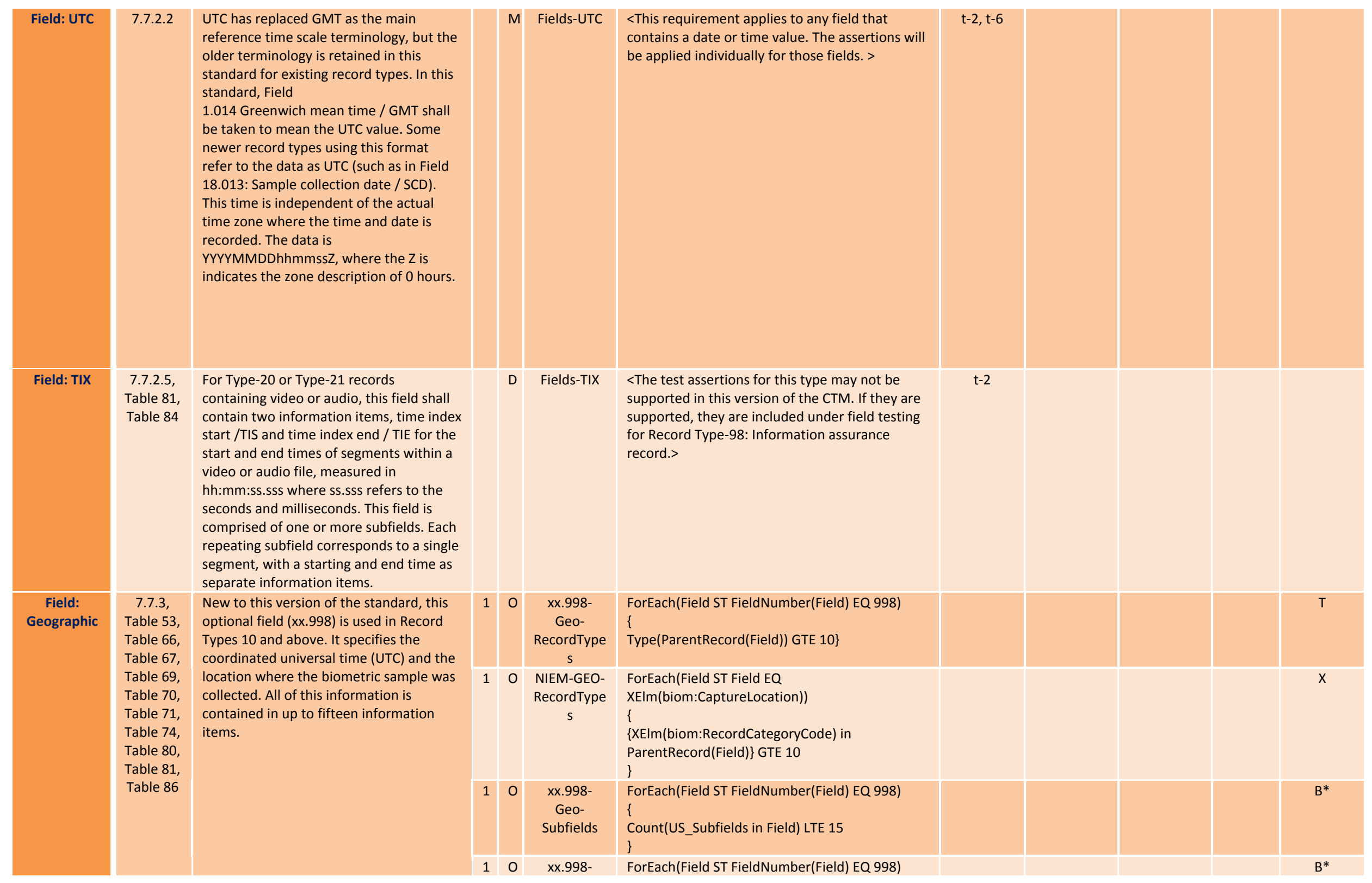



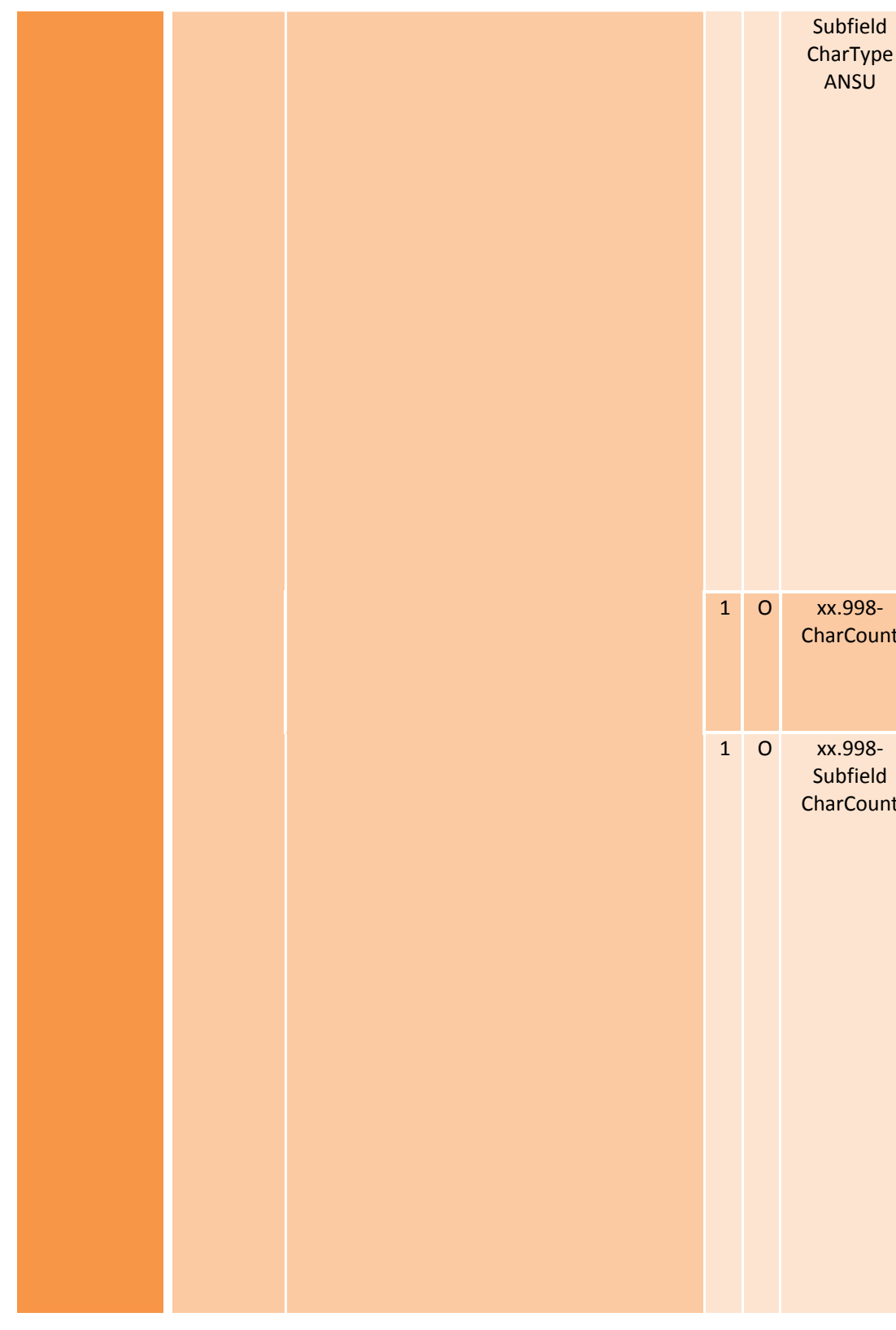

\{

Bytes(US_Subfield:1 in Field\}) MO [0×30 to 0x39,

$0 \times 5 \mathrm{~A}, 0 \times 7 \mathrm{~A}]$

AND

Bytes(US Subfield:2,5 in Field) MO

[OX2B, $0 \times 2 \mathrm{D}, 0 \times 2 \mathrm{E}, 0 \times 30$ to $0 \times 39$ ]

AND

Bytes(US_Subfield:3,6 in Field) MO [0x2E, 0x30 to $0 \times 39$ ]

Bytes(US Subfield:4,7,11,12 Field) MO [0×30 to

0x39]

AND

Bytes(US_Subfield:8 in Field) MO [0×2D, 0x30 to

0x39]

AND

Bytes(US_Subfield:9,10 in Field) MO [0x30 to

$0 \times 39,0 \times 41$ to $0 \times 5 \mathrm{~A}, 0 \times 61$ to $0 \times 7 \mathrm{~A}]$

AND

Present(Bytes(US_Subfield:113 to 15 in Field) ForEach(Field ST FieldNumber(Field) EQ 998)

DataLength(Field) MO [15 to 365]

ForEach(Field ST FieldNumber(Field) EQ 998)

Length(US_Subfield:1 in Field)) EQ 15 AND

Length(US_Subfield:2,14 in Field) MO [1 to 10] AND

Length(US_Subfield:3,6 in Field) MO [1 to 5] AND

Length(US_Subfield:4,7 in Field) MO [1 to 2] AND

Length(US_Subfield:5 in Field) MO [1 to 11] AND

Length(US_Subfield:8 in Field) MO [1 to 8] AND

Length(US_Subfield:9 in Field) MO [2 to 6]

AND

Length(US Subfield:10 in Field) EQ 5

AND

Length(US_Subfield:11,12 in Field) MO [2 to 5] AND

Length(US_Subfield:13 in Field) MO [1 to 150] 

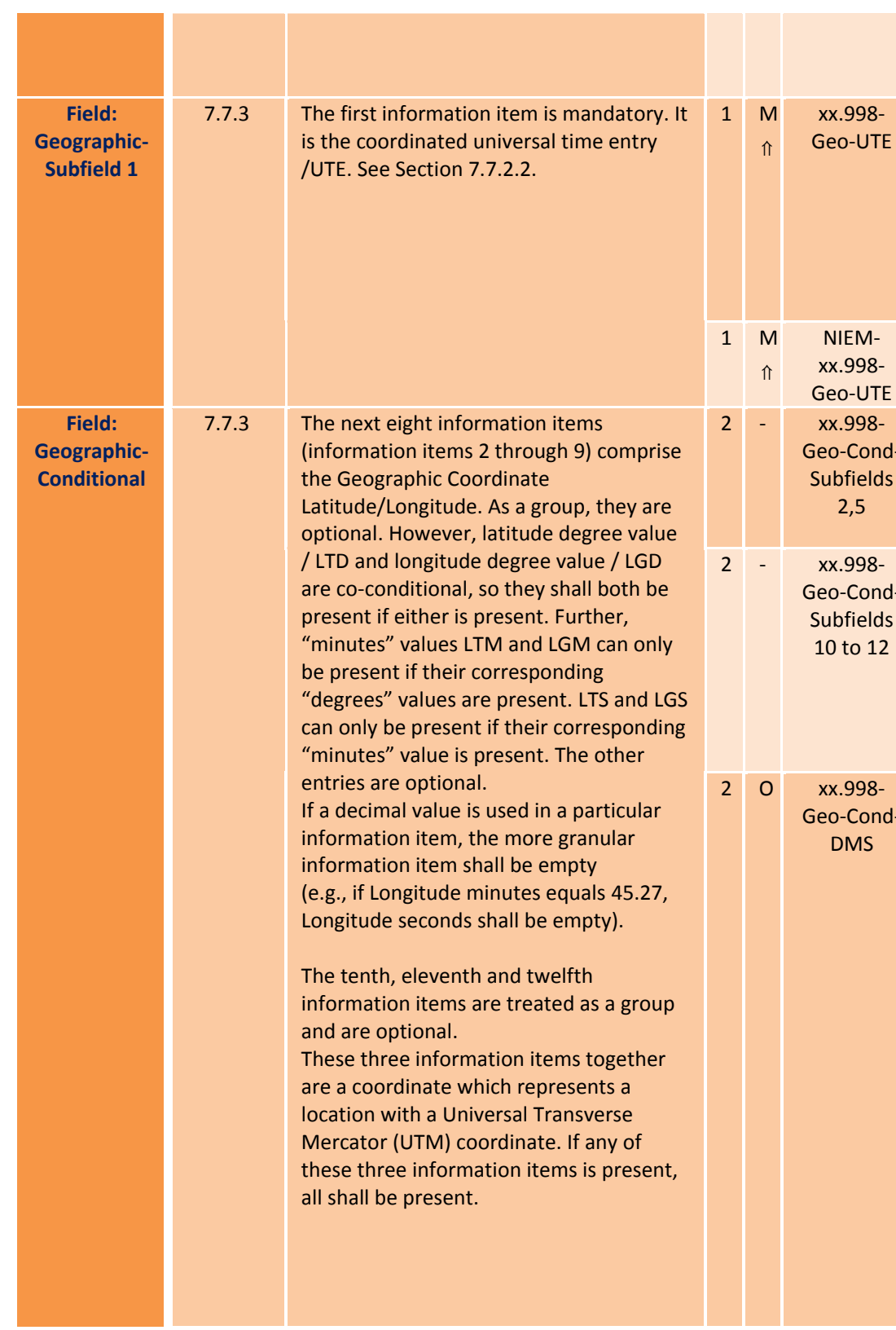

AND

Length(US_Subfield:15 in Field) MO [1 to 126] \}

ForEach(Field ST FieldNumber(Field) EQ 998)

Present(US_Subfield:1 in Field)

AND

\{US_Subfield:1 in Field $\}$ MO [ValidUTC/GMT] \}

$<$ The treatment of subfields for validation in the

\section{ForEach(Field ST FieldNumber(Field) EQ 998)}

\{

Present\{US_Subfield: 2 in Field $\}$ IFF

Present \{US_Subfield: 5 in Field $\}$ \}

ForEach(Field ST FieldNumber(Field) EQ 998)

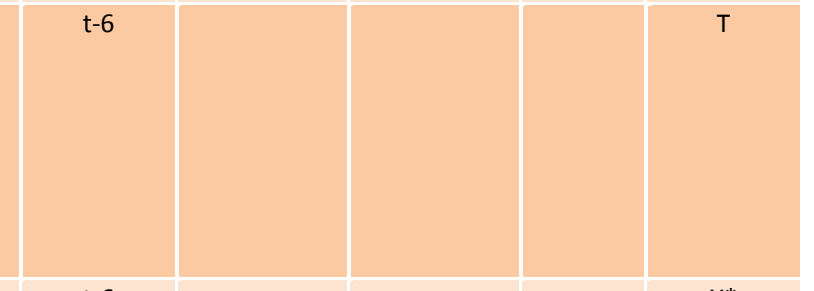

IF Present(US Subfield:10 OR US Subfield:11 OR

US_Subfield:12 in Field)

THEN

Present(US_Subfield:10 AND US_Subfield:11

AND US_Subfield:12 in Field)

ForEach(Field ST FieldNumber(Field) EQ 998)

Present (US Subfield: 4 in Field) THEN

Present(US_Subfield:3 in Field)

AND

IF Present(US_Subfield:3 in Field) THEN

Present (US Subfield: 2 in Field)

AND

IF Present(US_Subfield:7 in Field) THEN

Present (US Subfield: 6 in Field)

AND

IF Present(US_Subfield: 6 in Field) THEN

Present (US_Subfield:5 in Field) 

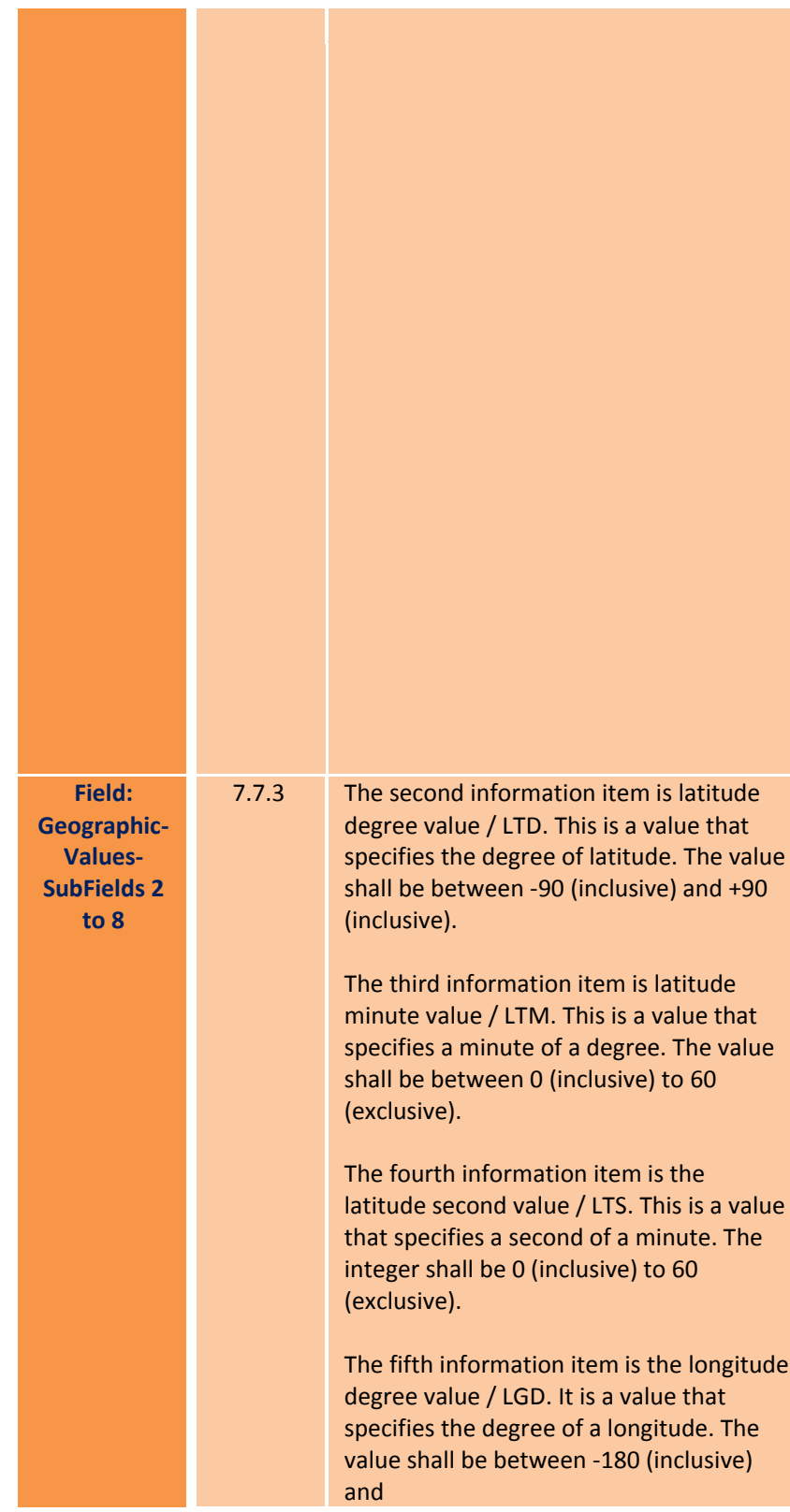

\begin{tabular}{|c|c|c|c|}
\hline & 0 & $\begin{array}{l}\text { xx.998- } \\
\text { Geo-Cond- } \\
\text { Decimals }\end{array}$ & $\begin{array}{l}\text { ForEach(Field ST FieldNumber(Field) EQ 998) } \\
\{ \\
\text { IF \{US_Subfield:2 in Field\} MOD } 1 \text { NEQ } 0 \text { THEN } \\
\text { Length(US_Subfield:3 in Field) EQ } 0 \text { AND } \\
\text { Length(US_Subfield:4) EQ } 0 \\
\text { AND } \\
\text { IF \{US_Subfield:3 in Field }\} \text { MOD } 1 \text { NEQ } 0 \text { THEN } \\
\text { Length(US_Subfield:4 in Field) EQ } 0 \\
\text { AND } \\
\text { IF \{US_Subfield:5 in Field }\} \text { MOD } 1 \text { NEQ } 0 \text { THEN } \\
\text { Length(US_Subfield:6 in Field) EQ } 0 \text { AND } \\
\text { Length(US_Subfield:7) EQ } 0 \\
\text { AND } \\
\text { IF }\{\text { US_Subfield:6 in Field }\} \text { MOD } 1 \text { NEQ } 0 \text { THEN } \\
\text { Length(US_Subfield:7 in Field) EQ } 0 \\
\text { \} }\end{array}$ \\
\hline 1 & - & $\begin{array}{l}\text { xx.998- } \\
\text { Geo- } \\
\text { Values- } \\
\text { Sub2 to } 8\end{array}$ & $\begin{array}{l}\text { ForEach(Field ST FieldNumber(Field) EQ 998) } \\
\{ \\
\text { \{US_Subfield: } 2 \text { in Field\} GTE -90 AND LTE } 90 \\
\text { AND } \\
\{\text { US_Subfield:3 in Field }\} \text { GTE } 0 \text { AND LT } 60 \\
\text { AND } \\
\text { \{US_Subfield: } 4 \text { in Field }\} \text { GTE } 0 \text { AND LT } 60 \\
\text { AND } \\
\text { \{US_Subfield:5 in Field }\} \text { GTE -180 AND LTE } 180 \\
\text { AND } \\
\text { \{US_Subfield: } 6 \text { in Field }\} \text { GTE } 0 \text { AND LT } 60 \\
\text { AND }\end{array}$ \\
\hline
\end{tabular}




\begin{tabular}{|c|c|c|c|c|c|c|c|c|}
\hline & & $\begin{array}{l}+180 \text { (inclusive). } \\
\text { The sixth information item is the } \\
\text { longitude minute value / LGM. It is a value } \\
\text { that specifies a minute of a degree. The } \\
\text { value shall be from } 0 \text { (inclusive) to } 60 \\
\text { (exclusive). } \\
\text { The seventh information item is the } \\
\text { longitude second value / LGS. This is a } \\
\text { value that specifies a second of a minute. } \\
\text { The integer shall be } 0 \text { (inclusive) to } 60 \\
\text { (exclusive). } \\
\text { The eighth information item is elevation / } \\
\text { ELE. It is expressed in meters. It is a } \\
\text { numeric value. It is between - } 422 \text { meters } \\
\text { (Dead Sea) and } 8848 \text { meters (Mount } \\
\text { Everest). }\end{array}$ & & & & $\begin{array}{l}\text { \{US_Subfield:7 in Field }\} \text { GTE } 0 \text { AND LT } 60 \\
\text { AND } \\
\{\text { US_Subfield: } 8 \text { in Field }\} \text { GTE }-422 \text { AND LTE } 8848 \\
\}\end{array}$ & & \\
\hline $\begin{array}{c}\text { Field: } \\
\text { Geographic- } \\
\text { Values- } \\
\text { SubField } 9\end{array}$ & $\begin{array}{c}\text { 7.7.3, } \\
\text { Table } 4\end{array}$ & $\begin{array}{l}\text { The ninth information item is the geodetic } \\
\text { datum code / GDC10. It is an } \\
\text { alphanumeric value of } 3 \text { to } 6 \text { characters in } \\
\text { length. This information item is used to } \\
\text { indicate which coordinate system was } \\
\text { used to represent the values in } \\
\text { information items } 2 \text { through } 7 \text {. If no entry } \\
\text { is made in this information item, then the } \\
\text { basis for the values entered in the first } \\
\text { eight information items shall be WGS84, } \\
\text { the code for the World Geodetic Survey } \\
1984 \text { version - WGS } 84 \text { (G873). See Table } \\
4 \text { for values. }\end{array}$ & 1 & 0 & $\begin{array}{c}\text { xx.998- } \\
\text { Geo- } \\
\text { Values- } \\
\text { Sub9 }\end{array}$ & $\begin{array}{l}\text { ForEach(Field ST FieldNumber(Field) EQ 998) } \\
\{ \\
\text { \{US_Subfield:9 in Field\} MO [ASCII(AIRY, AUST, } \\
\text { BES, BESN, CLK66, CLK80, EVER, FIS60, FIS68, } \\
\text { GRS67, HELM, HOUG, INT, KRAS, AIRYM, EVERM, } \\
\text { FIS60M, SA69, WGS60, WGS66, WGS72, } \\
\text { WGS84)] } \\
\text { OR } \\
\text { Length(US_Subfield:9 in Field) MO [3 to 6] AND } \\
\text { Bytes(US_Subfield:9 in Field) MO [0x30 to 0x39, } \\
\text { Ox41 to 0x5A, 0x61 to 0x7A] } \\
\text { OR } \\
\text { Length(US_Subfield:9 in Field) EQ } 0 \\
\}\end{array}$ & $\mathrm{t}-7$ & $\mathrm{~B}^{*}$ \\
\hline $\begin{array}{c}\text { Field: } \\
\text { Geographic- } \\
\text { Values- } \\
\text { SubField } 10\end{array}$ & 7.7.3 & $\begin{array}{l}\text { The tenth information item is the } \\
\text { geographic coordinate universal } \\
\text { transverse Mercator zone / GCM. It is an } \\
\text { alphanumeric value of } 5 \text { characters. } \\
\text { - The first two characters represent the } \\
6^{\circ} \text { wide UTM zone. Leading zeros are } \\
\text { included. } \\
\text { - The third character is a letter } \\
\text { designating the band of latitude. } \\
\text { - The fourth and fifth characters are a } \\
\text { pair of letters identifying one of the } \\
\text { 100,000-meter grid squares within the } \\
\text { grid zone (UPS area). }\end{array}$ & 1 & 0 & $\begin{array}{c}\text { xx.998- } \\
\text { Geo- } \\
\text { Values- } \\
\text { Sub10 }\end{array}$ & $\begin{array}{l}\text { ForEach(Field ST FieldNumber(Field) EQ 998) } \\
\{ \\
\text { \{Bytes: } 1 \text { in US_Subfield:10 in Field }\} \text { * } 10+ \\
\text { \{Bytes: } 2 \text { in US_Subfield:10 in Field\} GTE } 1 \text { AND } \\
\text { LTE } 60 \\
\text { AND } \\
\text { \{Bytes: } 3 \text { to } 5 \text { in US_Subfield: } 10 \text { in Field }\} \text { MO } \\
\text { [ASCII(Cto X)] AND NOT MO [ASCII(I,O)] } \\
\text { \} }\end{array}$ & $t-8$ & $\mathrm{~B}^{*}$ \\
\hline
\end{tabular}




\begin{tabular}{|c|c|c|c|c|c|c|c|c|}
\hline & & & 1 & 0 & $\begin{array}{l}\text { xx.998-Geo } \\
\text {-Sub10- } \\
\text { ValidZone }\end{array}$ & $\begin{array}{l}\text { ForEach(Field ST FieldNumber(Field) EQ 998) } \\
\{ \\
\{\text { US_Subfield:10 in Field\} MO [ValidZone] } \\
\}\end{array}$ & $\mathrm{t}-8$ & $\mathrm{~B}^{*}$ \\
\hline $\begin{array}{l}\text { Field: } \\
\text { Geographic- } \\
\text { Values- } \\
\text { SubField } 11 \\
\text { and } 12\end{array}$ & 7.7.3 & $\begin{array}{l}\text { The eleventh information item is the } \\
\text { geographic coordinate universal } \\
\text { transverse } \\
\text { Mercator easting / GCE. It is an integer of } \\
\text { 2-digits for } 1 \text { kilometer precision, 3- } \\
\text { digits for } 100 \text { meter precision, 4-digits for } \\
10 \text { meter precision and 5-digits for } 1 \\
\text { meter precision. } \\
\text { The twelfth information item is the } \\
\text { geographic coordinate universal } \\
\text { transverse } \\
\text { Mercator northing / GCN. It is an integer } \\
\text { of 2-digits for } 1 \text { kilometer precision, 3- } \\
\text { digits for } 100 \text { meter precision, 4-digits for } \\
10 \text { meter precision and 5-digits for } 1 \\
\text { meter precision. }\end{array}$ & 2 & D & $\begin{array}{c}\text { xx.998- } \\
\text { Geo- } \\
\text { Values- } \\
\text { Sub11,12 }\end{array}$ & $\begin{array}{l}\text { ForEach(Field ST FieldNumber(Field) EQ 998) } \\
\{ \\
\text { Length(US_Subfield:11,12 in Field) GTE } 2 \text { AND } \\
\text { LTE } 5 \\
\text { AND } \\
\text { Bytes(US_Subfield:11,12 in Field) MO [ASCII(0 to } \\
\text { 9)] } \\
\text { ? }\end{array}$ & & $\mathrm{B}^{*}$ \\
\hline $\begin{array}{c}\text { Field: } \\
\text { Geographic- } \\
\text { Values- } \\
\text { SubField } 13\end{array}$ & 7.7.3 & $\begin{array}{l}\text { The thirteenth information item is } \\
\text { optional. It is the geographic reference } \\
\text { text /GRT. This information item is an } \\
\text { alphanumeric entry of up to } 150 \\
\text { characters. It is a } \\
\text { free form text describing a street address } \\
\text { or other physical location (such as 'Corner } \\
\text { of Washington and Madison, Geneva, } \\
\text { NY'). }\end{array}$ & 1 & 0 & $\begin{array}{l}\text { xx.998- } \\
\text { Geo- } \\
\text { Values- } \\
\text { Sub13 }\end{array}$ & $\begin{array}{l}\text { ForEach(Field ST FieldNumber(Field) EQ 998) } \\
\{ \\
\text { Length(US_Subfield:13 in Field) LTE } 150 \\
\}\end{array}$ & & $\mathrm{B}^{*}$ \\
\hline $\begin{array}{c}\text { Field: } \\
\text { Geographic- } \\
\text { Values- } \\
\text { SubField } 14\end{array}$ & 7.7.3 & $\begin{array}{l}\text { A fourteenth optional information item } \\
\text { geographic coordinate other system } \\
\text { identifier / OSI allows for other } \\
\text { coordinate systems. This information } \\
\text { items specifies the system identifier. It is } \\
\text { up to } 10 \text { characters in length. Examples } \\
\text { are: } \\
\text { - MGRS (Military Grid Reference System) } \\
\text { - USNG (United States National Grid) } \\
\text { - GARS (Global Area Reference System) }\end{array}$ & 1 & 0 & $\begin{array}{l}\text { xx.998- } \\
\text { Geo- } \\
\text { Values- } \\
\text { Sub14 }\end{array}$ & $\begin{array}{l}\text { ForEach(Field ST FieldNumber(Field) EQ 998) } \\
\{ \\
\text { Length(US_Subfield:14 in Field) LTE } 10 \\
\}\end{array}$ & & $\mathrm{B}^{*}$ \\
\hline
\end{tabular}




\begin{tabular}{|c|c|c|c|c|c|c|c|c|}
\hline & & $\begin{array}{l}\text { - GEOREF (World Geographic Reference) } \\
\text { - LANDMARK landmark (e.g. hydant) and } \\
\text { position relative to the landmark. }\end{array}$ & & & & & & \\
\hline \multirow[t]{2}{*}{$\begin{array}{l}\text { Field: } \\
\text { Geographic- } \\
\text { Values- } \\
\text { SubField } 15\end{array}$} & \multirow[t]{2}{*}{ 7.7.3 } & \multirow{2}{*}{$\begin{array}{l}\text { A fifteenth optional information item is } \\
\text { the geographic coordinate other system } \\
\text { value / OCV. It shall only be present if OSI } \\
\text { is present in the record. It can be up to } \\
126 \text { characters in length. If OSI is } \\
\text { LANDMARK, OCV is free text and may be } \\
\text { up to } 126 \text { characters. For details on the } \\
\text { formatting of OCV for the other } \\
\text { coordinate } \\
\text { systems shown in OSI as examples, see } \\
\text { http://earth- } \\
\text { info.nga.mil/GandG/coordsys/grids/refer } \\
\text { encesys.html }\end{array}$} & 1 & D & $\begin{array}{l}\text { xx.998- } \\
\text { Geo- } \\
\text { Values- } \\
\text { Sub15 }\end{array}$ & $\begin{array}{l}\text { ForEach(Field ST FieldNumber(Field) EQ 998) } \\
\{ \\
\text { Length(US_Subfield:15 in Field) LTE } 126 \\
\}\end{array}$ & $t-7$ & $\mathrm{~B}^{*}$ \\
\hline & & & 2 & D & $\begin{array}{l}\text { xx.998- } \\
\text { Geo-Cond- } \\
\text { OCV }\end{array}$ & $\begin{array}{l}\text { ForEach(Field ST FieldNumber(Field) EQ 998) } \\
\{ \\
\text { IF Present(US_Subfield:15 in Field) THEN } \\
\text { Present(US_Subfield: } 14 \text { in Field) } \\
\}\end{array}$ & & $\mathrm{B}^{*}$ \\
\hline $\begin{array}{l}\text { Field: } \\
\text { Impression- } \\
\text { Values }\end{array}$ & $\begin{array}{c}\text { 7.7.4.1, } \\
\text { Table 5, } \\
8.4 .3, \\
8.9 .3, \\
8.13 .3 \\
8.14 .3 \\
8.15 .3, \\
8.19 .3\end{array}$ & $\begin{array}{l}\text { This field contains a code from Table } 5 \text { for } \\
\text { how the friction ridge sample was } \\
\text { collected. It has been expanded in this } \\
\text { version of the standard to include } \\
\text { plantars and unknowns. }\end{array}$ & & $M$ & $\begin{array}{l}{[4,9,13,14} \\
15,19] .003- \\
\text { IMP }\end{array}$ & $\begin{array}{l}<\text { The test assertions for these types vary for this } \\
\text { requirement, and therefore included under field } \\
\text { testing for the specific Record Types.> }\end{array}$ & $\mathrm{t}-2$ & \\
\hline $\begin{array}{l}\text { Field: FGP- } \\
\text { Values }\end{array}$ & $\begin{array}{c}\text { 7.7.4.2, } \\
\text { Table 6, } \\
8.4 .4, \\
8.9 .5 .9, \\
8.13 .13, \\
8.14 .13, \\
8.15 .13, \\
8.19 .13\end{array}$ & $\begin{array}{l}\text { This field is used in Record types dealing } \\
\text { with friction ridges. It specifies which } \\
\text { friction ridge biometric sample was } \\
\text { collected. Note that for codes } 1-40 \text { and } \\
60-84 \text {, the Table } 6 \text { specifies } \\
\text { recommended MAXIMUM width and } \\
\text { height. (Individual implementation } \\
\text { domains and application profiles may use } \\
\text { different values.) } \\
\text { In previous versions of this standard, FGP } \\
\text { was used for finger position, and PLP for } \\
\text { palmprint position. They are now in one } \\
\text { table, along with the codes added in the } \\
\text { ANSI/NIST-ITL 1a-2009 amendment. New } \\
\text { to this version, plantar codes are included } \\
\text { in the table. In order to cover all of these } \\
\text { cases, the name was changed to friction } \\
\text { ridge generalized position / FGP. }\end{array}$ & & $M$ & $\begin{array}{l}\text { 4.004, } \\
9.134, \\
{[13,14,15,1} \\
9] .013-F G P\end{array}$ & $\begin{array}{l}<\text { The test assertions for these types vary for this } \\
\text { requirement, and therefore included under field } \\
\text { testing for the specific Record Types.> }\end{array}$ & $t-2$ & \\
\hline $\begin{array}{l}\text { Field: PPD } \\
\text { Conditional }\end{array}$ & 7.7.4.3 & $\begin{array}{l}\text { For exemplar fingerprints contained in } \\
\text { Type-14 records, if the impression is } \\
\text { known to be an entire joint image (EJI), }\end{array}$ & 2 & D & $\begin{array}{l}\text { Type-14- } \\
\text { Cond-FGP- } \\
\text { PPD }\end{array}$ & $\begin{array}{l}\text { Present(14.014) IFF Present(US_Subfield in } \\
14.013 \text { ST \{US_Subfield\} EQ 19) }\end{array}$ & & $\mathrm{B}^{*}$ \\
\hline
\end{tabular}




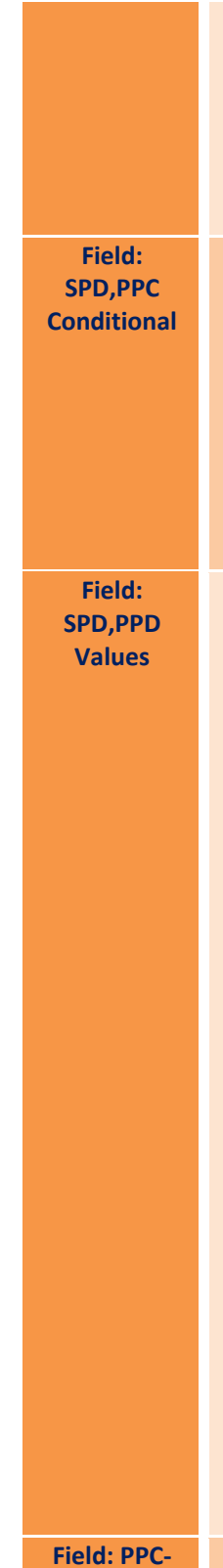

Field: PPC- full finger view (FFV), or extreme tip (TIP), then Field 14.013: Friction ridge

generalized position / FGP shall be set to 19, and Field 14.014: Print position descriptors / PPD shall be specified; Field 14.015: Print position coordinates /PPC may be (optionally) specified.

7.7.4.3 For latent prints contained in Type-13 records, if all or part of the impression should be compared against the medial or proximal segments or the extreme tips, then Field 13.013: Friction ridge generalized position / FGP shall be set to 19, and Field 13.014: Search position descriptors / SPD shall be specified; Field 13.015: Print position coordinates / PPC may be (optionally) specified.

7.7.4.3, The position descriptor, in Field 13.014: Table 6, Search position descriptors / SPD or Field Table7 14.014: Print position descriptors / PPD 14.014: Print position descriptors / PPD
contains two mandatory information items:

For a Type-13 record (latent prints), the first information item (probable decimal finger position code / PDF) (0-10, 16 or 17) is taken from Table 6. A " 0 " indicates that all the fingers of a possible candidate should be searched. For a Type-14 record (known exemplars), the first information item is the friction ridge generalized position / FGP. It is also taken from Table 6 with a value of 1 to 10 , inclusive or 16 or 17 .

The second information item (finger image code / FIC) is the code taken from Table 7 to indicate the portion of the database to search. Full-length finger joint images use codes FV1 through FV4. Figure 2 is an illustration of the Entire Joint Image for a middle finger with each of the full finger views and constituent parts identified. Multiple portions of the EJI may be listed in a separate subfield.
2

D Type-13SPD-PPC

(1)

1 D 13.014-

Subfield 1-

PDF

AND

F Present(14.015) THEN Present(US_Subfield in

14.013 ST \{US_Subfield\} EQ 19)

Present(13.014) IFF Present(US_Subfield in

13.013 ST \{US_Subfield\} EQ 19)

AND

IF Present(13.015) THEN Present(US_Subfield in

13.013 ST \{US_Subfield\} EQ 19)

ForEach(RS_Subfield in 13.014)

\{US

$16,17]$

1 D $\begin{gathered}14.014- \\ \text { Subfield 1- }\end{gathered}$ FGP

\{US_Subfield:1 in RS_Subfield\} MO [1 to 10 , $16,17]$

D $[13,14] .014$ ForEach(RS_Subfield in $[13,14] .014)$

-Subfield 2-

$\mathrm{FIC}$

\{US_Subfield:2 in RS_Subfield\} MO [ASCIII

10 [13,14].015 Count(RS_Subfields in [13,14].015) MO [1 to 12] 


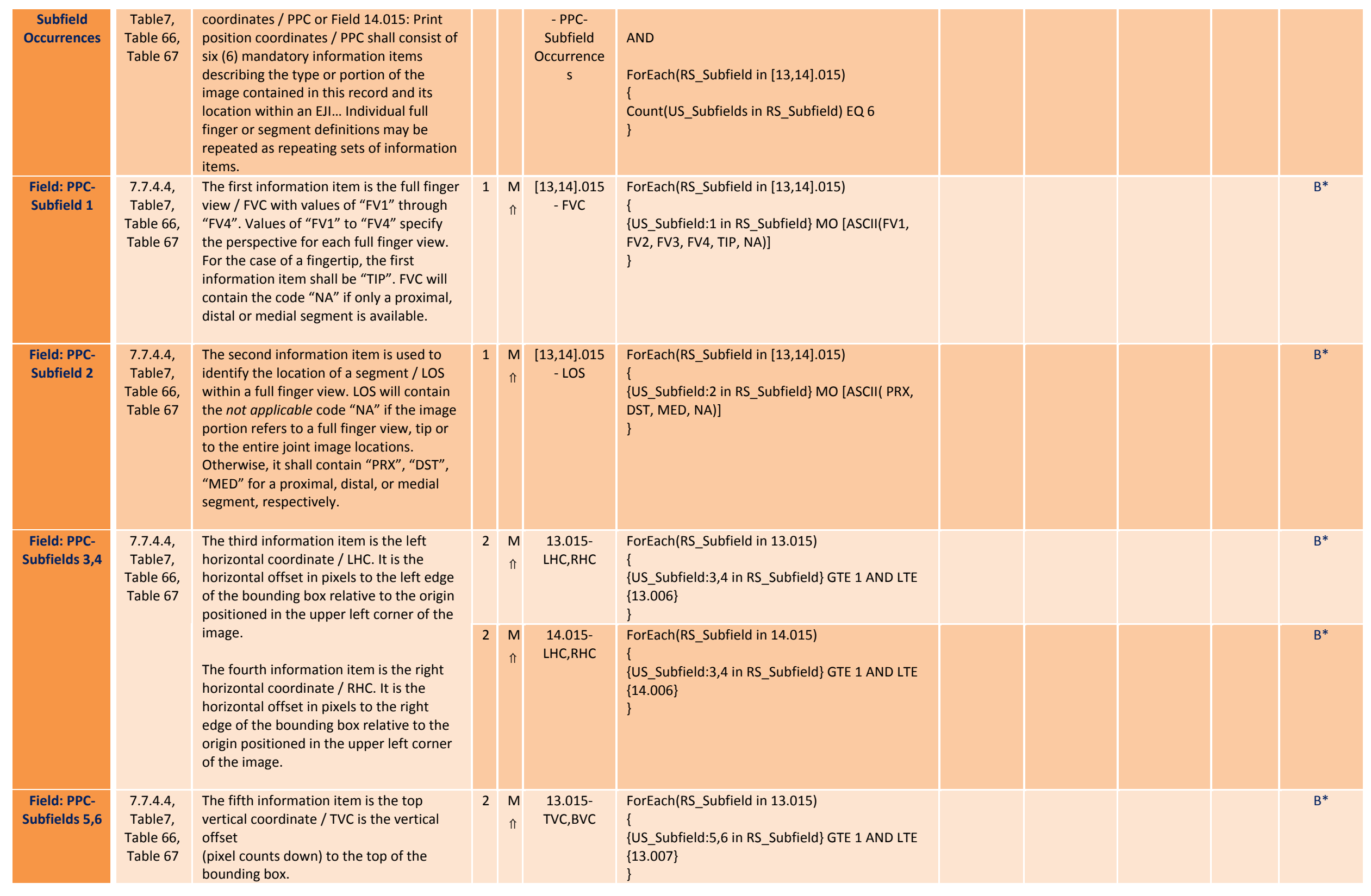




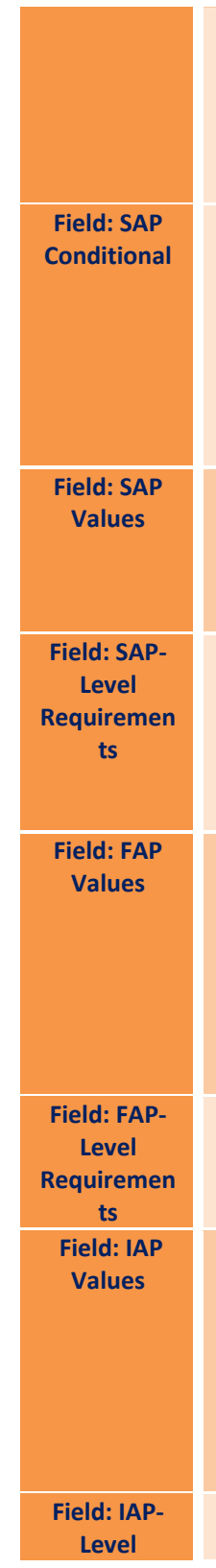

The sixth information item is the bottom vertical coordinate / BVC. It is the vertical offset from the upper left corner of the image down to the bottom of the

bounding box. It is counted in pixels.

7.7.5, SAP codes are mandatory in Type-10

8.10.13 records with a face image, optional in

Type-14 records, and optional in Type-17

records...

The Subject Acquisition Profile (SAP) is a mandatory field when Field 10.003: Image type / IMT contains "FACE". Otherwise, it shall not be entered.

7.7.5.1, Field 10.013: Subject acquisition profile / Table 8 SAP is used to indicate the SAP level code for face as indicated in Table 8. The SAP codes 32,42 and 52 are new to this version of the standard.

7.7.5.1.1 <Sections 7.7.5.1.1 to 7.7.5.1.10 describe to requirements for the image for various

2 M 14.015$\Uparrow \quad T V C, B V C$ SAP Levels.> 0 ,

Table 9

Annex E

7.7.5.2,

Table 10

The profile levels for fingerprint

acquisition are optional and are based upon those listed in the Mobile ID Best

Practice Recommendation. They are

entered in Field 14.031:

Subject acquisition profile - fingerprint /

FAP, which is new to this version of the standard.

7.7.5.2, <Section 7.7.5.2 and Table 10 describe

Table 10 requirements for the image for various

FAP Levels.>

7.7.5.3, The profile levels for iris acquisition,

Table 71

which are new to this version of the

standard, are optional and are based

upon those listed in the Mobile ID Best

Practice Recommendation (BPR) (See

Annex G: Bibliography) . They are entered

in Field 17.031: Subject acquisition profile

- iris / IAP.

7.7.5.3 <Section 7.7.5.3 describes requirements for the image for various IAP Levels.>

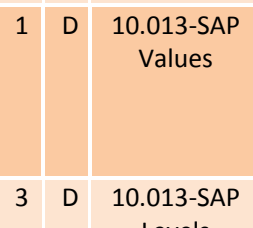

Levels

2 D $\begin{aligned} & 10.013-S A P \\ & \text { Conditional }\end{aligned}$

Present(10.013) IFF

$\{10.003\}$ EQ ASCII (FACE)

ForEach(RS Subfield in 14.015)

\{US_Subfield:5,6 in RS_Subfield\} GTE 1 AND LTE $\{14.007\}$

$\{10.013\}$ MO $[0,1,10-15,20,30,32,40,42,50-52]$

$<$ Not Tested. Determining the condition under which the image was captured to verify the SAP Level is not feasible at this time.>

$1 \quad$ O 14.031-FAP

Values

\section{$\{14.031\} \mathrm{MO}[10,20,30,40,50,60]$}

3 O 14.031-SAP

Levels

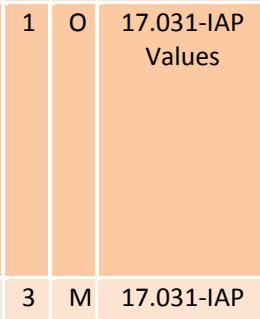

Levels

Level is not feasible at this time.>
$<$ Not Tested. Determining the condition under which the image was captured to verify the IAP
$<$ Not Tested. Determining the condition under

which the image was captured to verify the FAP

\begin{tabular}{l}
\begin{tabular}{l}
$\{17.031\}$ MO $[20,30,40]$ \\
\hline
\end{tabular} \\
\hline \\
\hline $\begin{array}{l}<\text { Not Tested. Determining the condition under } \\
\text { which the image was captured to verify the IAP }\end{array}$
\end{tabular}




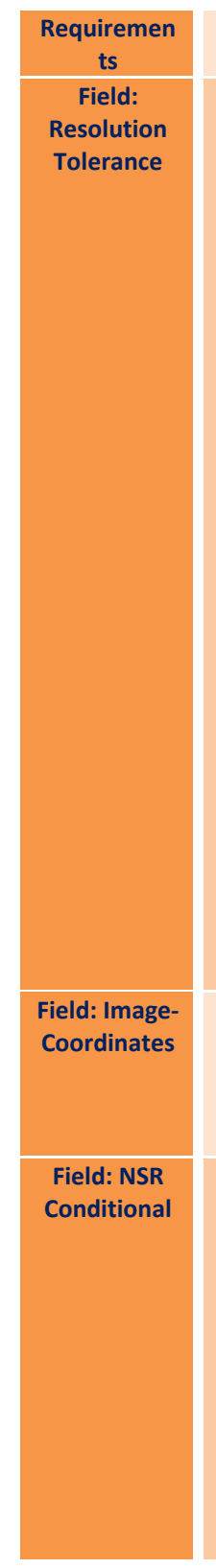

For Appendix F certified devices,

resolution accuracy shall not vary more

than $1 \%$ from the class resolution. A class resolution of $19.69 \mathrm{ppmm}$ (500 ppi) has a lower bound of 19.49

ppmm (495ppi) and an upper bound of

19.89 ppmm (505ppi).

For Personal

Identity Verification (PIV) certified devices with fingerprint subject application profile (FAP) Levels 10 to 40 only resolution accuracy shall not vary more than $2 \%$

from the class Resolution. For example, a class resolution of $19.69 \mathrm{ppmm}$ (500 ppi) has a

lower bound of $19.30 \mathrm{ppmm}$ (490ppi) and an upper bound of $20.08 \mathrm{ppmm}$ (510ppi).

Tolerance requirements shall apply to the class and nominal resolution

requirements throughout this document.

This transmitting resolution does not have to be the same as the scanning resolution. However, the transmitting resolution shall be within the range of permissible

resolution values for that record type.

7.7.6.2 Each image formatted in accordance with this standard shall appear to have been captured in an upright position and approximately centered horizontally in the field of view...

7.7.6.2.1, If Type-4 records are included in the

Table 11 transaction, Field 1.011 Native scanning resolution /

NSR contains five characters specifying the native scanning resolution in pixels per millimeter. It is expressed as two numeric characters followed by a decimal point and two more numeric characters (e.g. 19.69). This field is set to “00.00" if no Type- 4 records are present in the

transaction. With the deprecation of

Record Types-3, 5 and 6, NSR only directly
Level is not feasible at this time.>

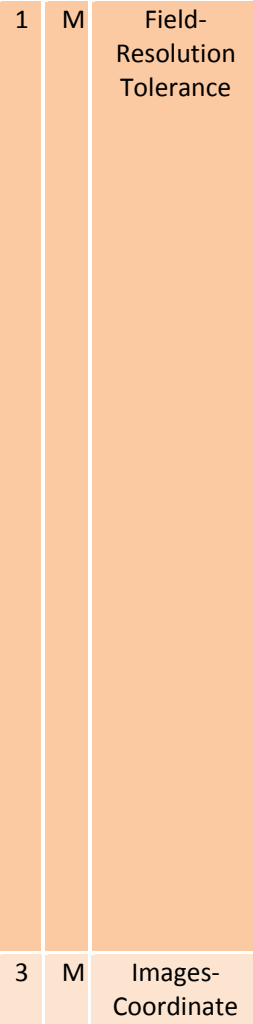

$<$ This requirement specifies a tolerance for al resolution values expressed throughout the standard. If there is a resolution requirement for a type, the resolution must follow the $1 \%$ or $2 \%$ tolerance as described in the standard. This requirement will be applied to each applicable resolution requirement.>

$<$ Not directly tested, but this convention is used

when testing for conformance in each of the assertions related to images>

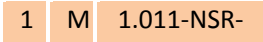

Length(1.011) EQ 5

Length

M 1.011-NSR-

Bytes:1,2,4,5 in $1.011 \mathrm{MO}[0$ to 9 ]

Values

\section{AND}

\section{M 1.011-NSR- Conditional}

\section{M NIEM-NSR-}

Conditional

IF NOT Pr 1.011 EQ ".

THEN

$\{1.011\}$ EQ 00.00

F NOT

Present(XEIm(itl:PackageHighResolutionGrayScal elmageRecord))

THEN t-2 


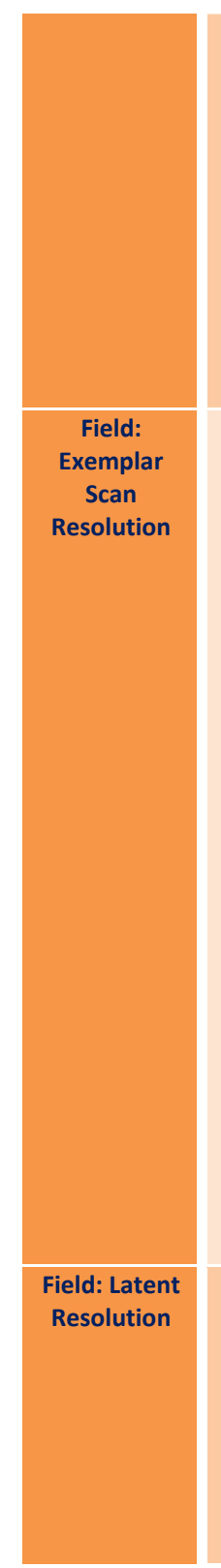

applies to Record Type- 4 in this version of the standard. New to this version of the standard, NSR does not apply to Type-7 records, unless specified as such by an implementation domain.

Record Type-14 shall be used if scanning fingerprint image at the 1000 ppi class or above.

It can also be used for the $500 \mathrm{ppi}$

class.Record Type- 4 shall not be used for anything but the 500 ppi class.

Exemplar images shall have a minimum class scanning resolution of $500 \mathrm{ppi}$. The migration path to higher scanning

resolutions for image capturing devices with a native scanning resolution of the 500 ppi class shall be at a rate of $100 \%$ of the current native scanning resolution. Capture devices with native scanning resolutions not in step with this migration path shall provide (through subsampling, scaling, or interpolating downward) a nominal resolution that matches the next lower interval in the migration path. For example,

a device with native scanning resolution of 47.24 ppmm (1200 ppi) shall provide a class

resolution of 39.37 ppmm (1000 ppi). The scanner resolution is specified for Record Types 14, 15, 16, 17, 19 and 20 using Scanned horizontal pixel scale / SHPS (See Section 7.7.8.7) and Scanned vertical pixel scale / SVPS (See Section 7.7.8.8). These Record Types can handle all resolutions, and are thus called variable-resolution image records.

Latent images should have a minimum class scanning resolution of $1000 \mathrm{ppi}$. Record Type-13 specifies resolution using Scanned horizontal pixel scale / SHPS (See Section 7.7.8.7) and Scanned vertical pixel scale / SVPS (See Section 7.7.8.8). Record Type-13 can handle all resolutions, and is thus called a variable-resolution image record.
$\{$ XElm(biom:NativeScanningResolutionValue) in XEIm(itl:PackagelnformationRecord)\} EQ 00.00

2 M $\begin{aligned} & \text { 1.011-NSR- } \\ & \text { Type4 } 500\end{aligned}$ Type4 500
ppi Only

2 M FieldsExemplar Valid Scan Resolutions

$<$ Scanning resolutions for Record Types

$\{1.011\}$ GTE 19.30 AND LTE 20.08

(19, 20 must migrate at a rate of $100 \%$ with a minimum of $500 \mathrm{ppi}$. These

assertions are included under field testing for the specific Record Types.>

\begin{tabular}{|l|c|c|}
\hline & Fields- \\
Latent \\
Valid Scan \\
Resolutions
\end{tabular}

\section{F $\{13.008\}$ EQ 1 THEN}

13.016\} AND $\{13.017\}$ GTE 990

AND

IF $\{13.008\}$ EQ 2 THEN

$\{13.016\}$ AND $\{13.017\}$ GTE

390 t-2
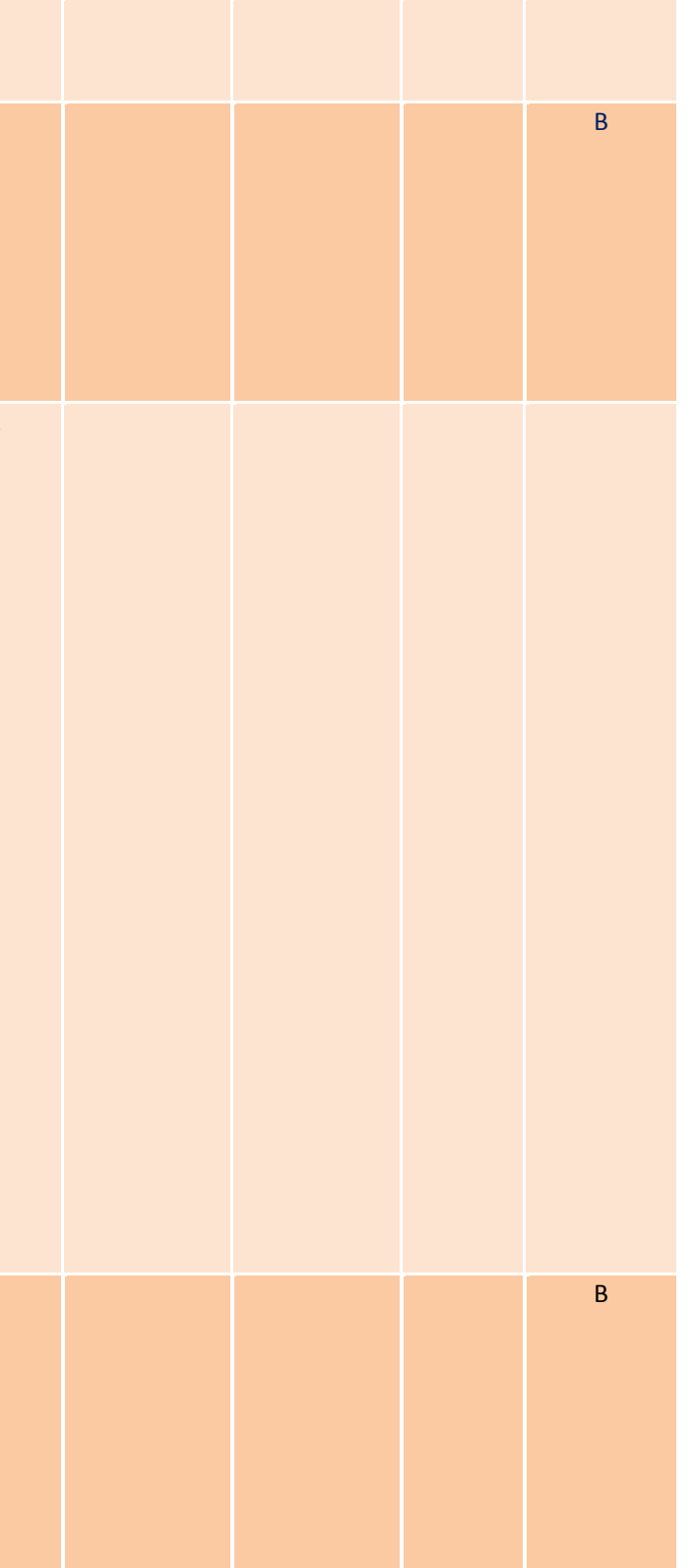


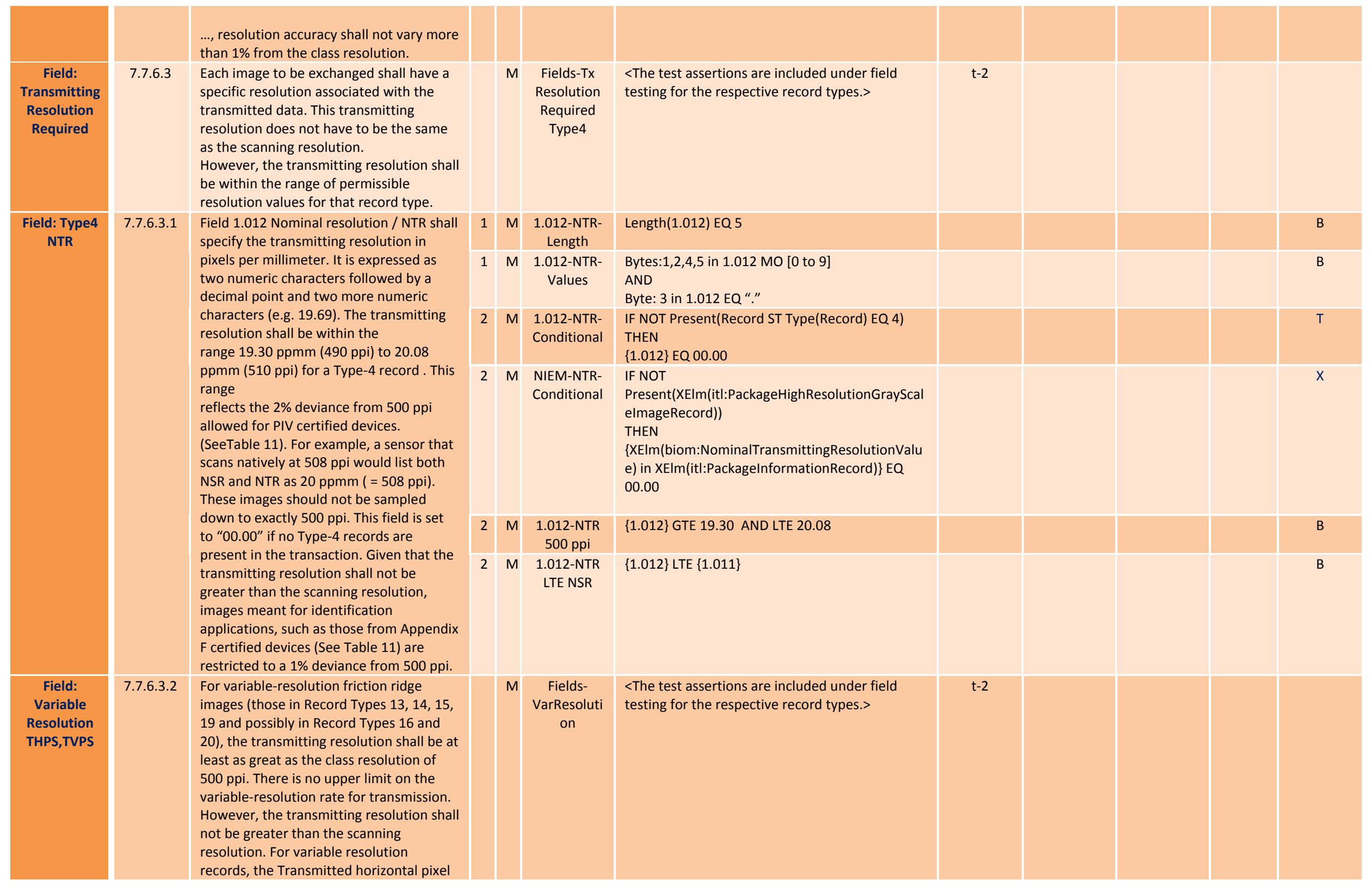




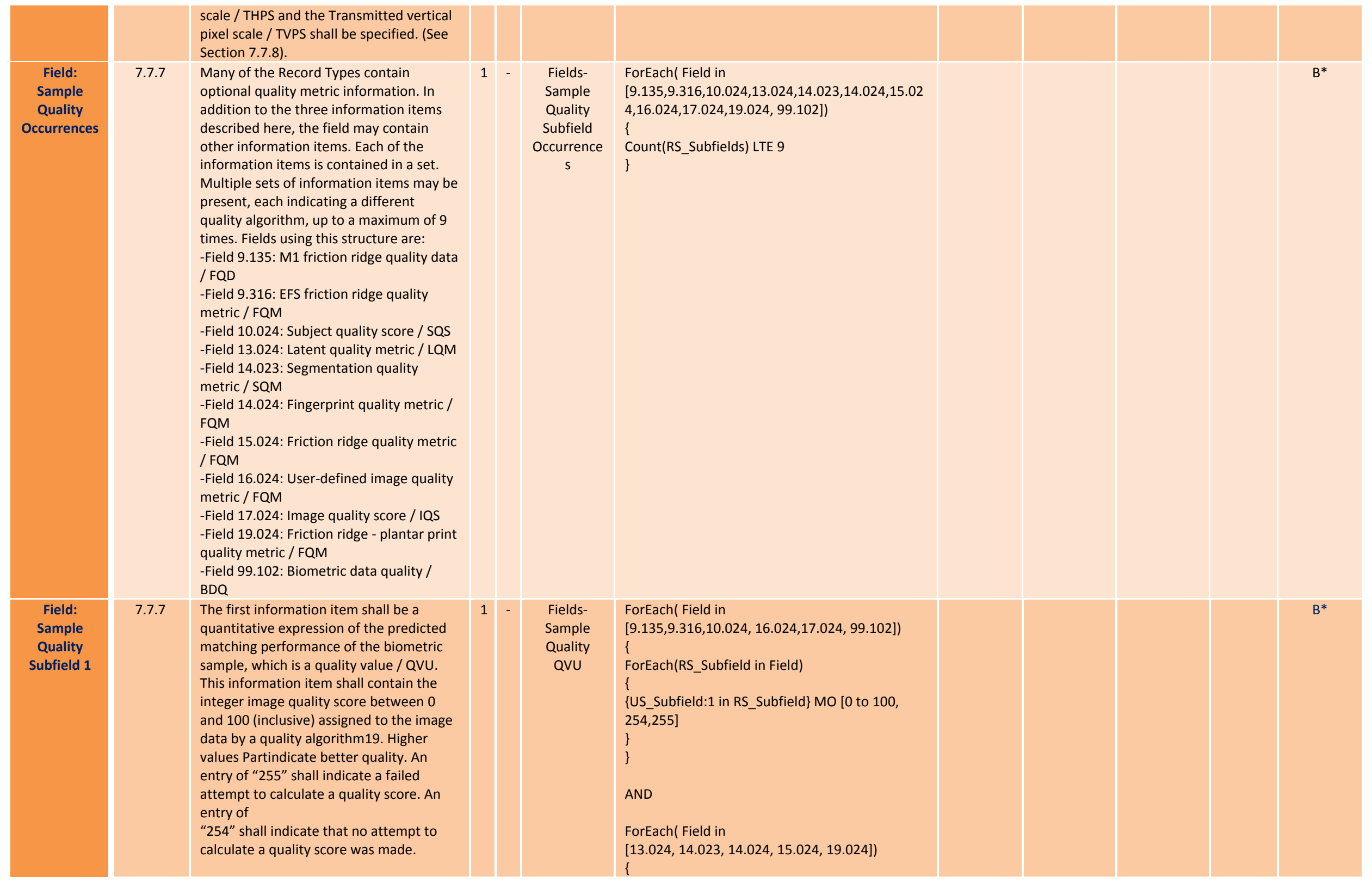




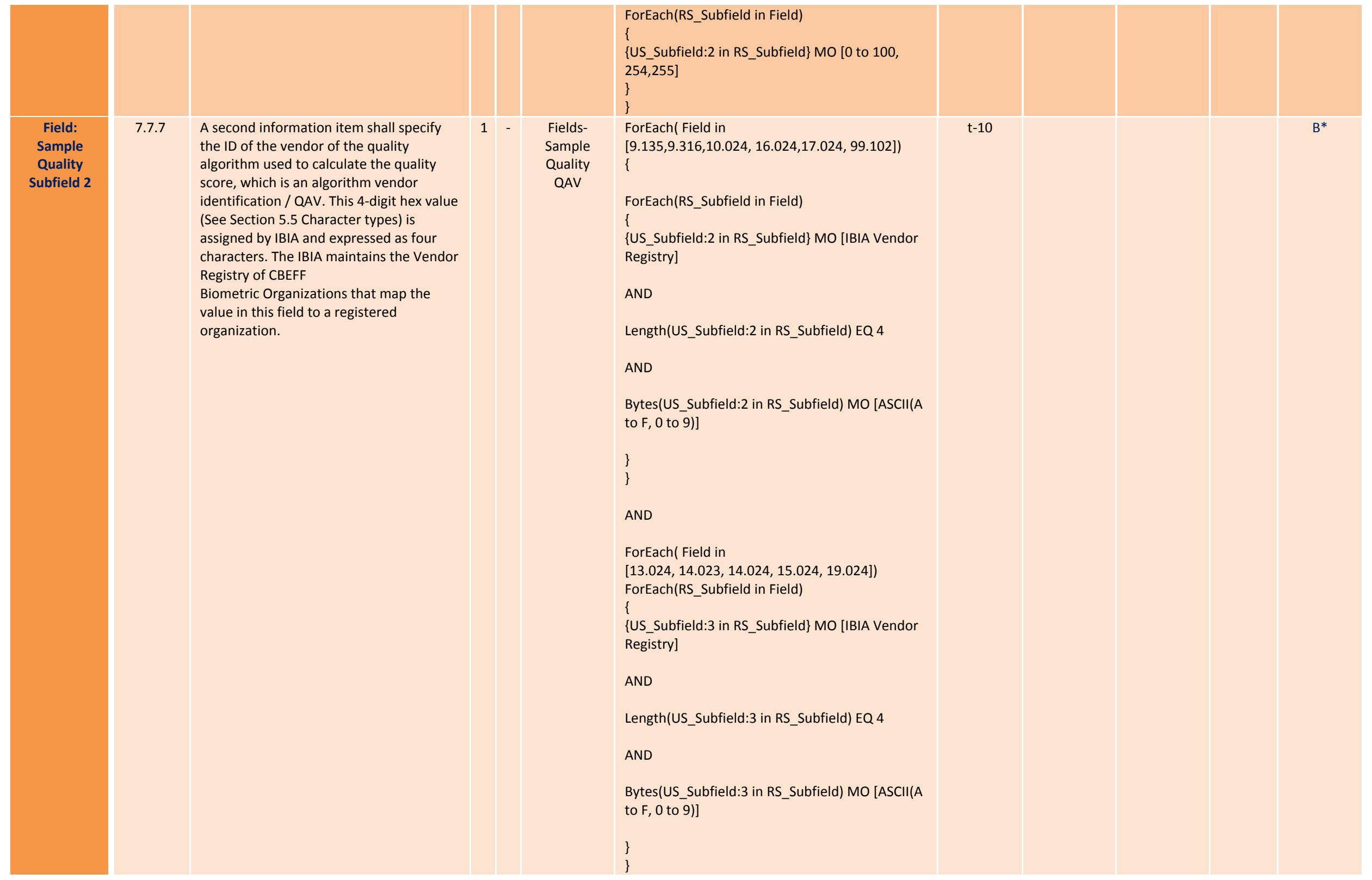




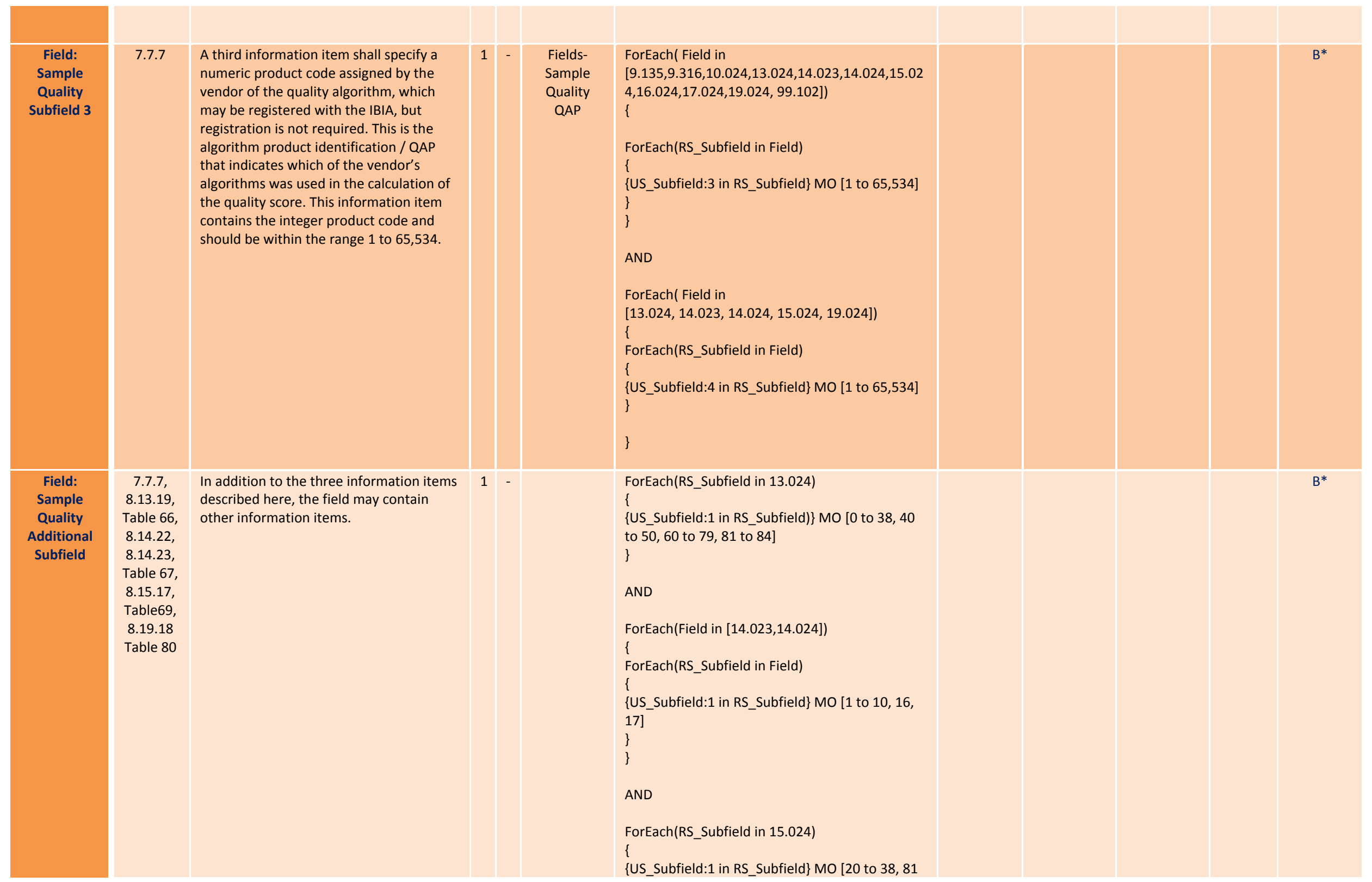



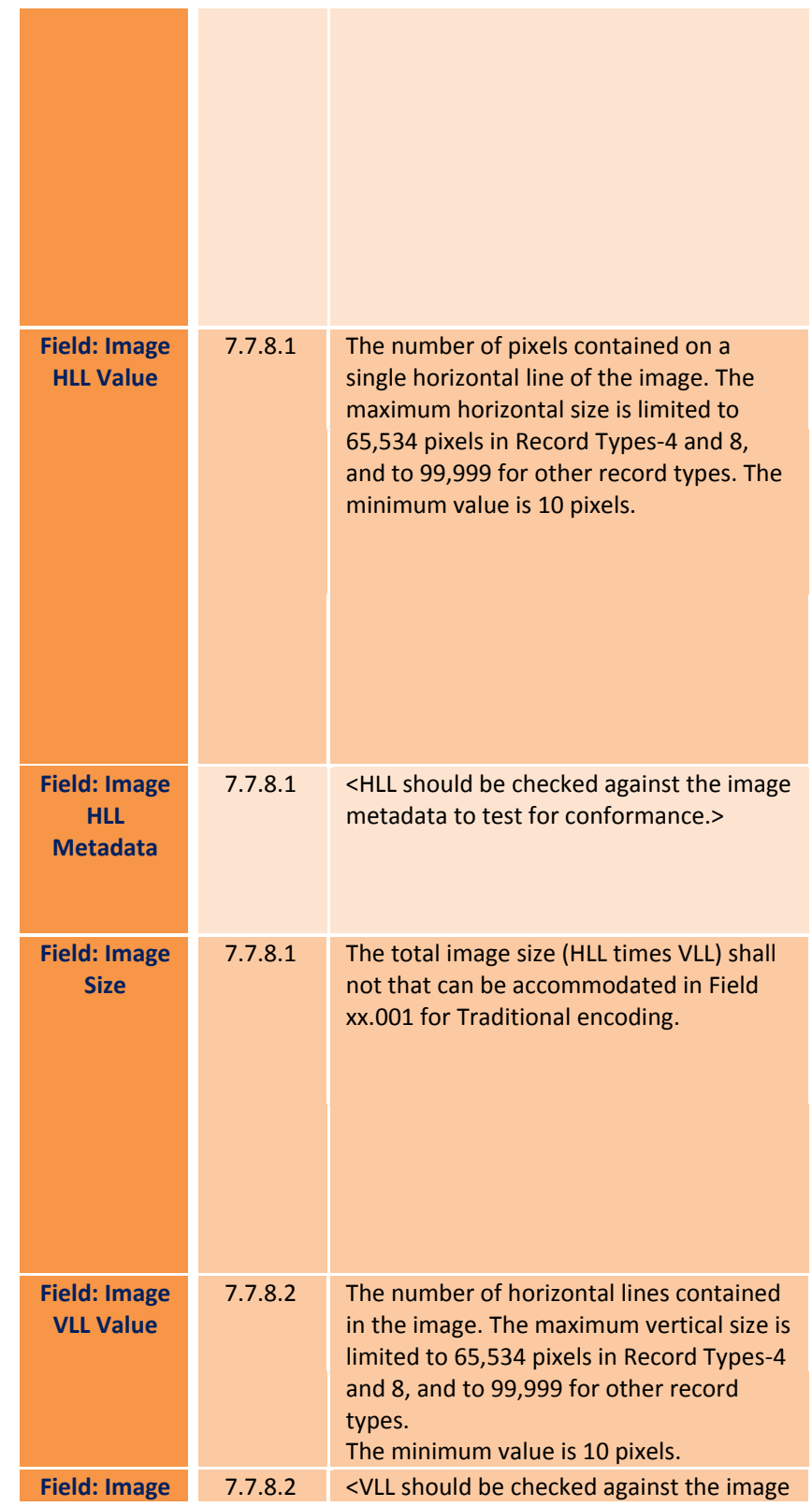

to 84

\}

AND

ForEach(RS Subfield in 19.024)

\{

\{US_Subfield:1 in RS_Subfield\} MO [60 to 77]

1 M $[4,8] .006-$

$\mathrm{HLL}$

$\{[4,8] .006\}$ GTE 10

AND LTE 65534

M 9.128-HLL $\quad\{9.128\}$ GTE 10

AND LTE 99,999
1 M xx.006-HLL

M Fields-HLL

Metadata

2 M $\begin{gathered}\text { xx.006,007- } \\ \text { Image Size }\end{gathered}$

M 9.128,129-

Image Size

1 M $[4,8] .007-$

VLL

$1 \quad M \quad x x .007-V L L$
$\{[10,13$ to $17,19,20] .006\}$ GTE 10 AND LTE 99,999

\section{$<$ The test assertions are included under field}

testing for the respective record types.>

$\{[4,8,10,13$ to $17,19,20] .006\}$ *

$\{[4,8,10,13$ to $17,19,20] .007\}$

LTE

$\{[4,8,10,13$ to $17,19,20] .001\}$

$\{9.128\} *\{9.129\}$ LTE $\{9.001\}$

$\{[4,8] .007\}$ GTE 10

$\{[10,13$ to $17,19,20] .007\}$ GTE 10

AND LTE 99,999
AND LTE 65,534
$<$ The test assertions are included under field

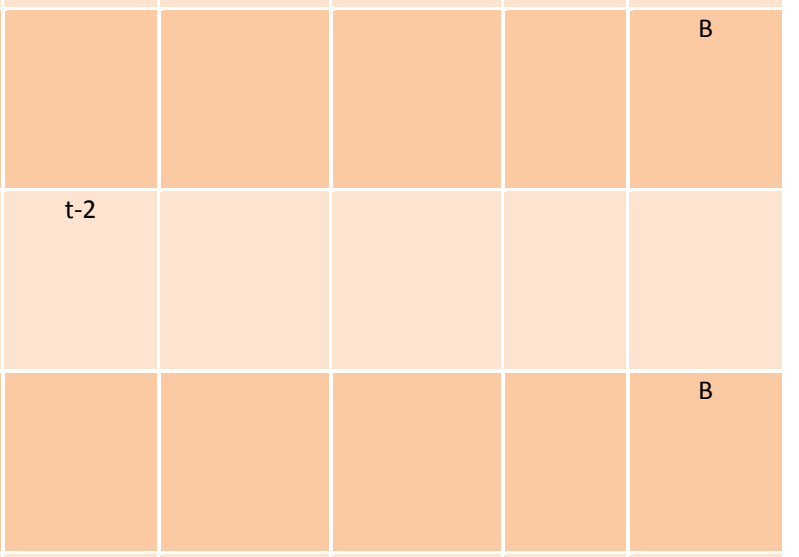

M Fields-VLL 


\begin{tabular}{|c|c|c|c|c|c|c|c|c|}
\hline $\begin{array}{c}\text { VLL } \\
\text { Metadata }\end{array}$ & & metadata to test for conformance.> & & & Metadata & testing for the respective record types.> & & \\
\hline \multirow{2}{*}{$\begin{array}{l}\text { Field: Image } \\
\text { SLC Value }\end{array}$} & \multirow[b]{2}{*}{$\begin{array}{c}\text { 7.7.8.3, } \\
\text { Table 24, } \\
\text { Table 53, } \\
\text { Table 66, } \\
\text { Table 71, } \\
\text { Table 80, } \\
\text { Table 81 }\end{array}$} & \multirow{2}{*}{$\begin{array}{l}\text { The image sampling frequency (pixel } \\
\text { density). } \\
\text { <Tables related to each Record Type } \\
\text { provide constraints on the value of SLC.> }\end{array}$} & 1 & M & 9.130-SLC & $\{9.130\} \mathrm{MO}[0,1,2]$ & & B \\
\hline & & & 1 & M & xx.008-SLC & $\{[10,13$ to $17,19,20] .008\} \mathrm{MO}[0,1,2]$ & & B \\
\hline $\begin{array}{l}\text { Field: Image } \\
\text { SLC } \\
\text { Metadata }\end{array}$ & 7.7.8.3 & $\begin{array}{l}\text { A value of " } 1 \text { " shall indicate pixels per } \\
\text { inch. } \\
\text { A value of " } 2 \text { " shall indicate pixels per } \\
\text { centimeter. A value of " } 0 \text { " in this field } \\
\text { indicates that no scale is provided, and } \\
\text { the quotient of THPS/TVPS shall provide } \\
\text { the pixel aspect ratio. } \\
\text { <SLC should be checked against the image } \\
\text { metadata to test for conformance.> }\end{array}$ & & M & $\begin{array}{l}\text { Fields-SLC } \\
\text { Metadata }\end{array}$ & $\begin{array}{l}<\text { The test assertions are included under field } \\
\text { testing for the respective record types. }>\end{array}$ & $\mathrm{t}-2$ & \\
\hline \multirow{2}{*}{$\begin{array}{l}\text { Field: Image } \\
\text { THPS Value }\end{array}$} & \multirow[b]{2}{*}{$\begin{array}{c}\text { 7.7.8.4, } \\
\text { Table 24, } \\
\text { Table 53, } \\
\text { Table 66, } \\
\text { Table 71, } \\
\text { Table 80, } \\
\text { Table } 81\end{array}$} & \multirow{2}{*}{$\begin{array}{l}<\text { Tables related to each Record Type } \\
\text { provide constraints on the value of } \\
\text { THPS.> }\end{array}$} & 1 & M & 9.131-THPS & $\{9.131\}$ GTE 1 AND LTE 99,999 & & B \\
\hline & & & 1 & M & $\begin{array}{l}\text { xx.009- } \\
\text { THPS }\end{array}$ & $\{[10,13$ to $17,19,20] .009\}$ GTE 1 AND LTE 99,999 & & B \\
\hline $\begin{array}{l}\text { Field: Image } \\
\text { THPS } \\
\text { Metadata }\end{array}$ & 7.7.8.4 & $\begin{array}{l}\text { This is the integer pixel density used in } \\
\text { the horizontal direction of the image if } \\
S L C \text { has a value of " } 1 \text { " or " } 2 \text { ". If SLC has a } \\
\text { value of "0", this information item shall } \\
\text { contain the horizontal component of the } \\
\text { pixel aspect ratio, up to } 5 \text { digits. } \\
\text { <THPS should be checked against the } \\
\text { image metadata to test for } \\
\text { conformance.> }\end{array}$ & & M & $\begin{array}{l}\text { Fields-THPS } \\
\text { Metadata }\end{array}$ & $\begin{array}{l}<\text { The test assertions are included under field } \\
\text { testing for the respective record types. }>\end{array}$ & $\mathrm{t}-2$ & \\
\hline \multirow{2}{*}{$\begin{array}{l}\text { Field: Image } \\
\text { TVPS Value }\end{array}$} & \multirow[b]{2}{*}{$\begin{array}{l}\text { 7.7.8.5, } \\
\text { Table 24, } \\
\text { Table 53, } \\
\text { Table 66, } \\
\text { Table 71, } \\
\text { Table 80, } \\
\text { Table }\end{array}$} & \multirow{2}{*}{$\begin{array}{l}<\text { Tables related to each Record Type } \\
\text { provide constraints on the value of TVPS.> }\end{array}$} & 1 & M & 9.132-TVPS & $\{9.132\}$ GTE 1 AND LTE 99,999 & & B \\
\hline & & & 1 & M & $\begin{array}{l}\mathrm{xx} .010- \\
\text { TVPS }\end{array}$ & $\{[10,13$ to $17,19,20] .010\}$ GTE 1 AND LTE 99,999 & & B \\
\hline
\end{tabular}




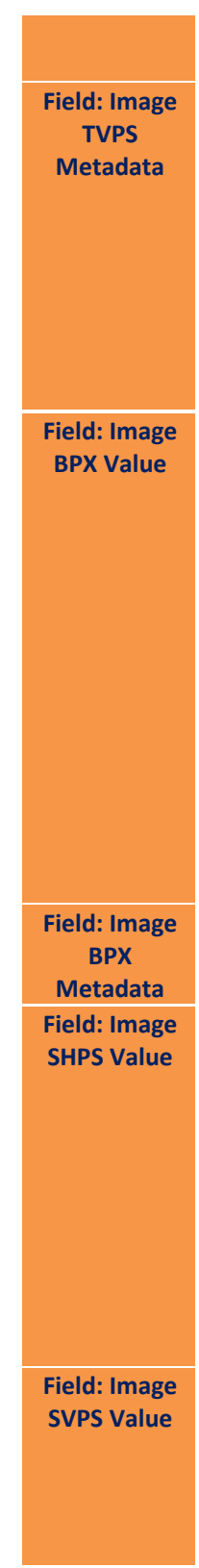

7.7.8.5 This is the integer pixel density used in the vertical direction of the image if SLC has a value of " 1 " or " 2 ". If SLC has a value of " 0 ", this information item shall contain the vertical component of the pixel aspect ratio, up to 5 digits.

$<$ TVPS should be checked against the image metadata to test for conformance.>

7.7.8.6, Some record types have a mandatory

field Bits per pixel / BPX. This contains the number of bits used to represent a pixel. This field shall contain an entry of " 8 " for normal grayscale values of " 0 " to " 255 ".

Any entry in this field greater than " 8 "

shall represent a grayscale pixel with

increased proportion. A maximum of 2 digits is allowed for this field.

Regardless of the compression algorithm used, the image shall be represented as an array of $n$ rows by $m$ columns by at

least 8-bit pixels. Each pixel in a gray-scale image shall be represented by eight or more bits.

7.7.8.6 <BPX should be checked against the image metadata to test for conformance.>

7.7.8.7 The horizontal pixel density used for the scanning of the original image /

impression providing that the SLC field

contains a " 1 " or " 2 ". Otherwise, this shall indicate the horizontal component of the pixel aspect ratio, up to 4 digits. This field is used if the transmission pixel scale differs from the original image scale, as listed in Transmitted horizontal pixel scale / THPS . Note that density is directly related to resolution.

The vertical pixel density used for the scanning of the original image / impression providing that the SLC field contains a " 1 " or " 2 ". Otherwise, this sh indicate the vertical component of the pixel aspect ratio, up to 4 digits. This field
M Fields-TVPS

Metadata

$<$ The test assertions are included under field

testing for the respective record types.>

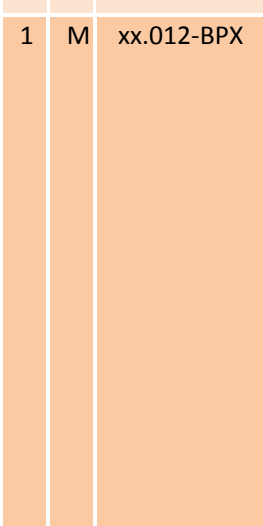

M Fields-BPX Metadata
$1 \quad 0 \quad x x .016-$ SHPS

O 17.022

\begin{tabular}{|l|r|}
\hline & 20.017 \\
\hline
\end{tabular}

\{17.022\} GTE 1 AND LTE 9,999

$\{20.017\}$ GTE 1 AND LTE 9,999

$$
\begin{array}{c|c|c|}
1 & 0 & \begin{array}{c}
x x .017- \\
\text { SVPS }
\end{array}
\end{array}
$$

\section{$\{[10,13,14,15,16,19] .016\}$ GTE 1 AND LTE 9,999}

\begin{tabular}{l|l|l|l|}
1 & 0 & 17.023
\end{tabular}

\begin{tabular}{l|l|r|}
1 & 0 & 20.018
\end{tabular}

$\{17.023\}$ GTE 1 AND LTE 9,999

$\{20.018\}$ GTE 1 AND LTE 9,999

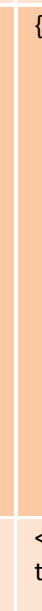

\{[13 to $17,19,20] .012\}$ GTE 8 AND LTE 99

$<$ The test assertions are included under field testing for the respective record types.> $\mathrm{t}-2$
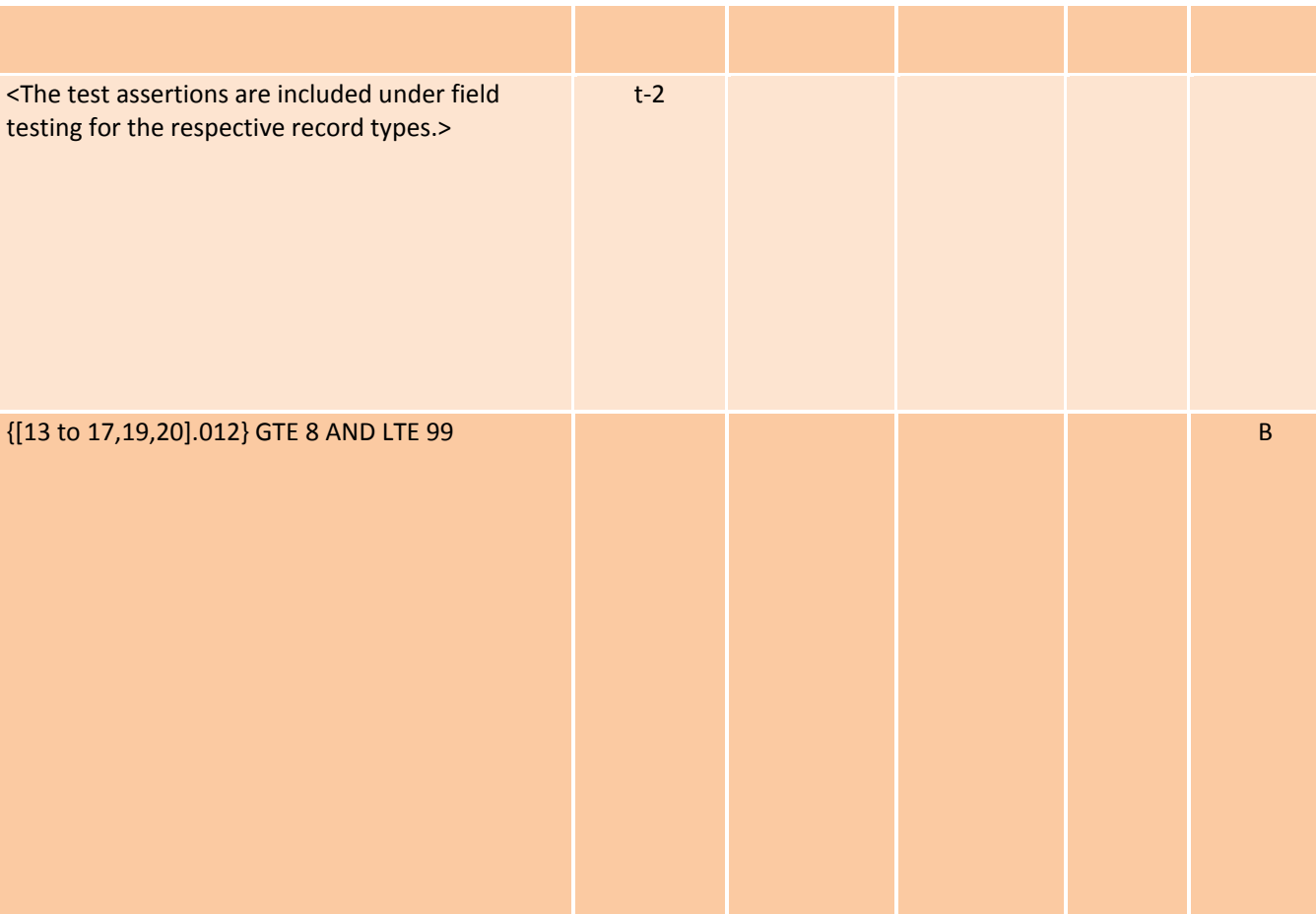

$\mathrm{t}-2$

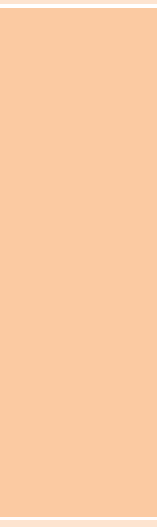




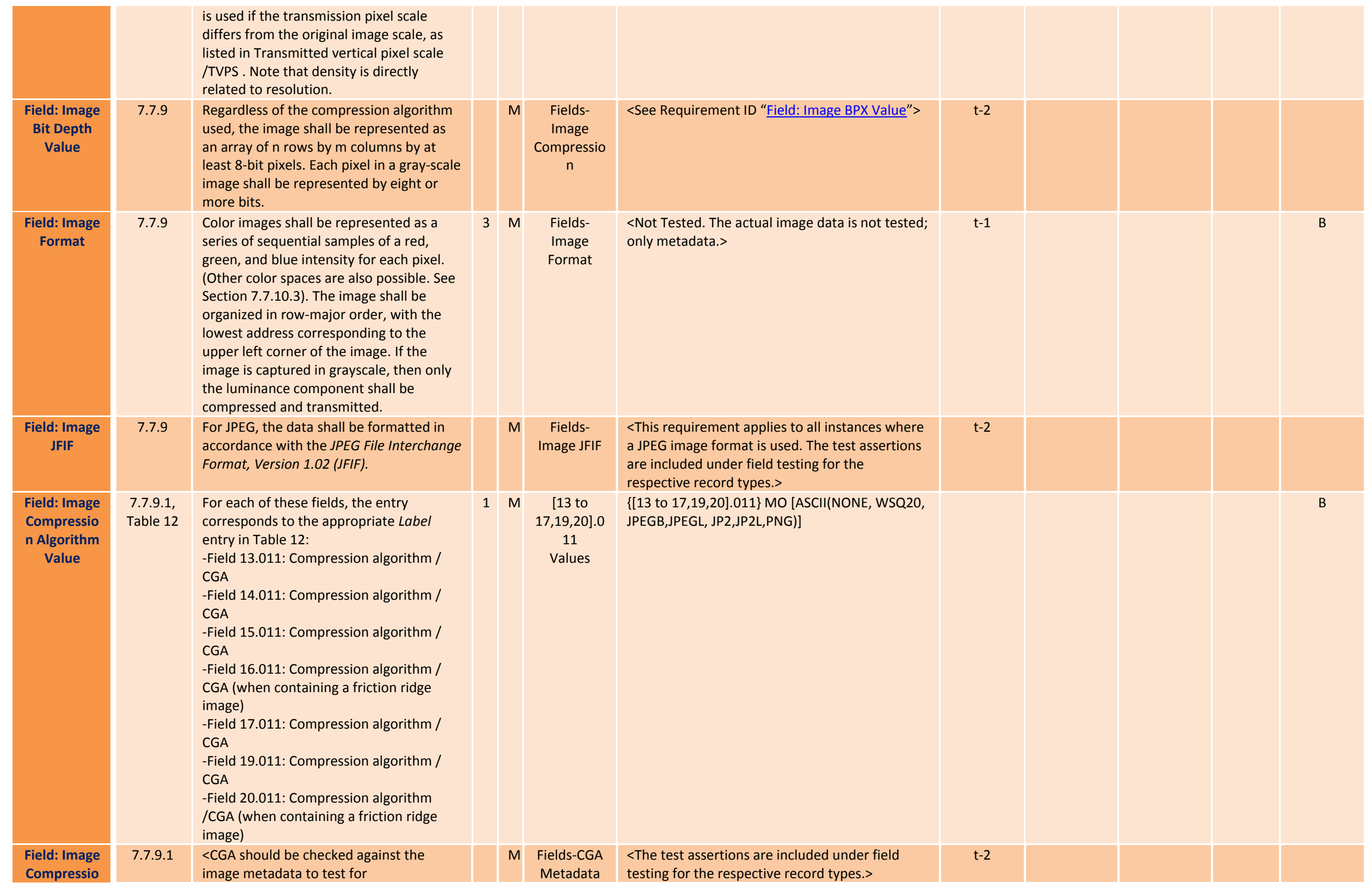




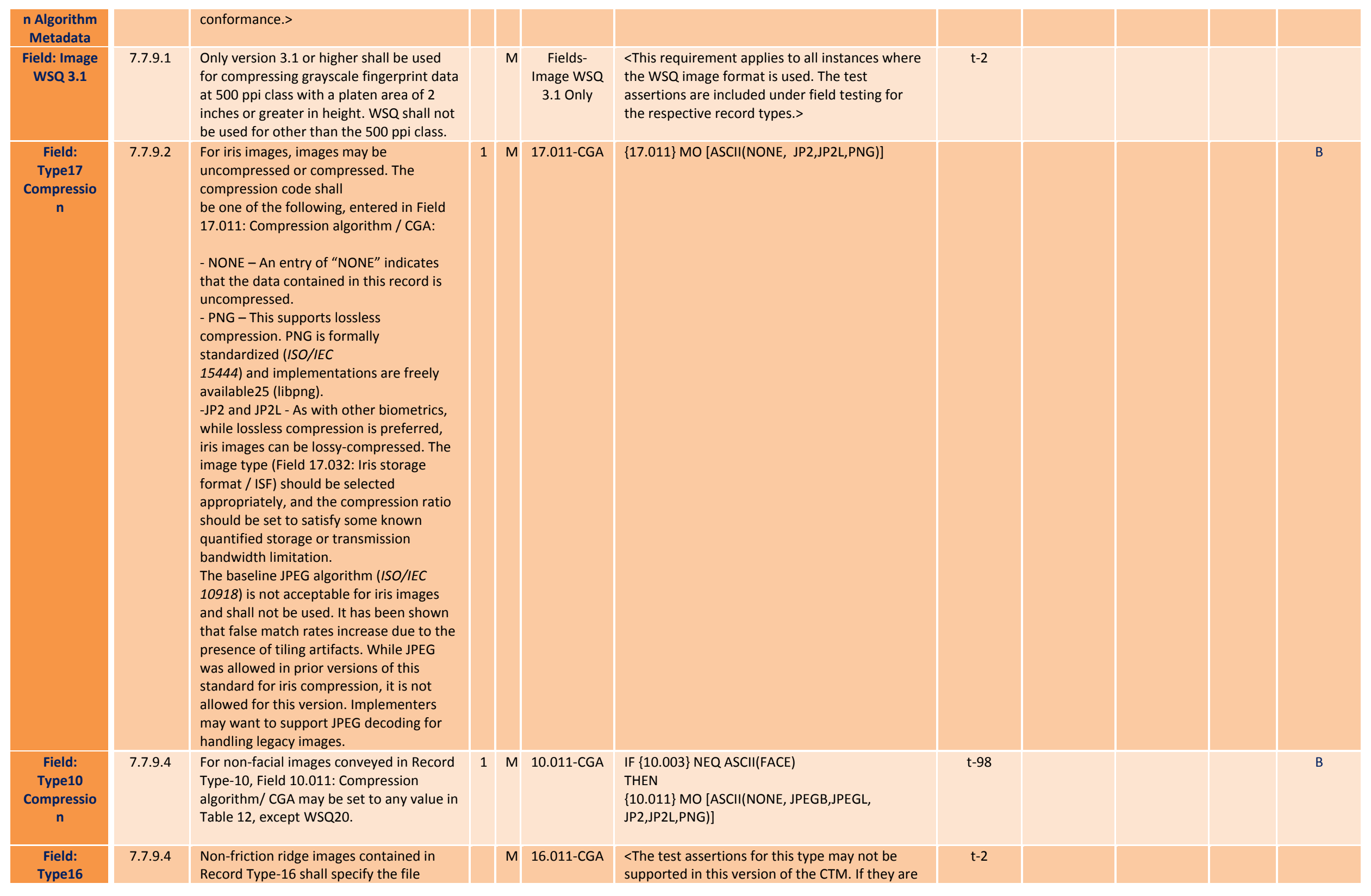




\begin{tabular}{|c|c|c|c|c|c|c|c|c|}
\hline $\begin{array}{l}\text { Compressio } \\
n\end{array}$ & & $\begin{array}{l}\text { extension (suffix) corresponding to the } \\
\text { compression used, such as OOG, JPG, } \\
\text { WAV, and PNG in Field 16.011: } \\
\text { Compression algorithm / CGA. A value of } \\
\text { "NONE" indicates that the data is } \\
\text { uncompressed. }\end{array}$ & & & & $\begin{array}{l}\text { supported, they are included under field testing } \\
\text { for Record Type-16: User-defined testing image } \\
\text { record. > }\end{array}$ & & \\
\hline \multirow[t]{2}{*}{$\begin{array}{l}\text { Field: Image } \\
\text { CSP Value }\end{array}$} & \multirow[t]{2}{*}{$\begin{array}{l}\text { 7.7.10.3, } \\
\text { Table } 13\end{array}$} & \multirow{2}{*}{$\begin{array}{l}\text { Several image record types have a field } \\
\text { Color space / CSP. It shall contain an entry } \\
\text { from the CODE column of Table } 13 \text {. If the } \\
\text { color image type cannot be determined, } \\
\text { an entry of } \\
\text { "RGB" shall be entered in this field. }\end{array}$} & 1 & $M$ & 10.012-CSP & $\begin{array}{l}\{10.012\} \mathrm{MO}[\text { ASCII(UNK, GRAY, RGB, SRGB, YCC, } \\
\text { SYCC)] }\end{array}$ & & B \\
\hline & & & 1 & M & xx.013-CSP & $\begin{array}{l}\{[16,17,20] .013\} \mathrm{MO}[\mathrm{ASCII}(\mathrm{UNK}, \mathrm{GRAY}, \mathrm{RGB} \\
\text { SRGB, YCC, SYCC)] }\end{array}$ & & B \\
\hline $\begin{array}{l}\text { Field: Image } \\
\text { ECL Value }\end{array}$ & $\begin{array}{l}\text { 7.7.11, } \\
\text { Table } 14\end{array}$ & $\begin{array}{l}\text { This information appears in Field 10.027: } \\
\text { Subject eye color / SEC and in Field } \\
17.020: \\
\text { Eye color / ECL. The eye color describes } \\
\text { the eye color of the subject as seen in the } \\
\text { image. } \\
\text { If unusual or unnatural, such as is the case } \\
\text { when colored contact lenses are present } \\
\text { and the 'real' eye color cannot be } \\
\text { ascertained, then the color shall be } \\
\text { labeled as "XXX". For near infra-red (NIR) } \\
\text { images, if this field is entered, it shall be } \\
\text { 'XXX'. Values for these fields shall be the } \\
\text { alphabetic entries in the "Attribute code" } \\
\text { column of Table } 14 .\end{array}$ & 1 & - & $\begin{array}{c}10.027,17.0 \\
20- \\
\text { EyeColor }\end{array}$ & $\begin{array}{l}\{10.027\} \text { AND }\{17.020\} \text { MO }[\text { ASCII(BLK, BLU, BRO, } \\
\text { GRY,GRN,HAZ,MAR,MUL, PNK, XXX)] }\end{array}$ & & B \\
\hline $\begin{array}{l}\text { Field: Image- } \\
\text { Paths }\end{array}$ & 7.8 & $\begin{array}{l}\text { Several Record Types define open paths } \\
\text { (also called contours or polylines) and / or } \\
\text { closed paths (polygons) on an image... } \\
\text { An open path is a series of connected line } \\
\text { segments that do not close or overlap. A } \\
\text { closed path (polygon) completes a circuit. } \\
\text { The closed path side defined by the last } \\
\text { vertex and the first vertex shall complete } \\
\text { the polygon. A polygon shall have at least } \\
3 \text { vertices. The contours in Record Type- } \\
\text { 17: Iris image record can be a circle or } \\
\text { ellipse. A circle only requires } 2 \text { points to } \\
\text { define it (See Table } 16 \text { ). } \\
\text { There are two different approaches to the } \\
\text { paths in this standard. The } 2007 \text { and } 2008 \\
\text { version of the standard used paths for } \\
\text { Field } 14.025: \text { Alternate finger segment } \\
\text { position(s) / ASEG. } \\
\text { That approach has been retained in this } \\
\text { version for all paths except in the }\end{array}$ & & - & $\begin{array}{l}\text { Fields- } \\
\text { Image- } \\
\text { Paths }\end{array}$ & $\begin{array}{l}<\text { The test assertions are included under field } \\
\text { testing for the respective record types. }>\end{array}$ & $\mathrm{t}-2$ & \\
\hline
\end{tabular}




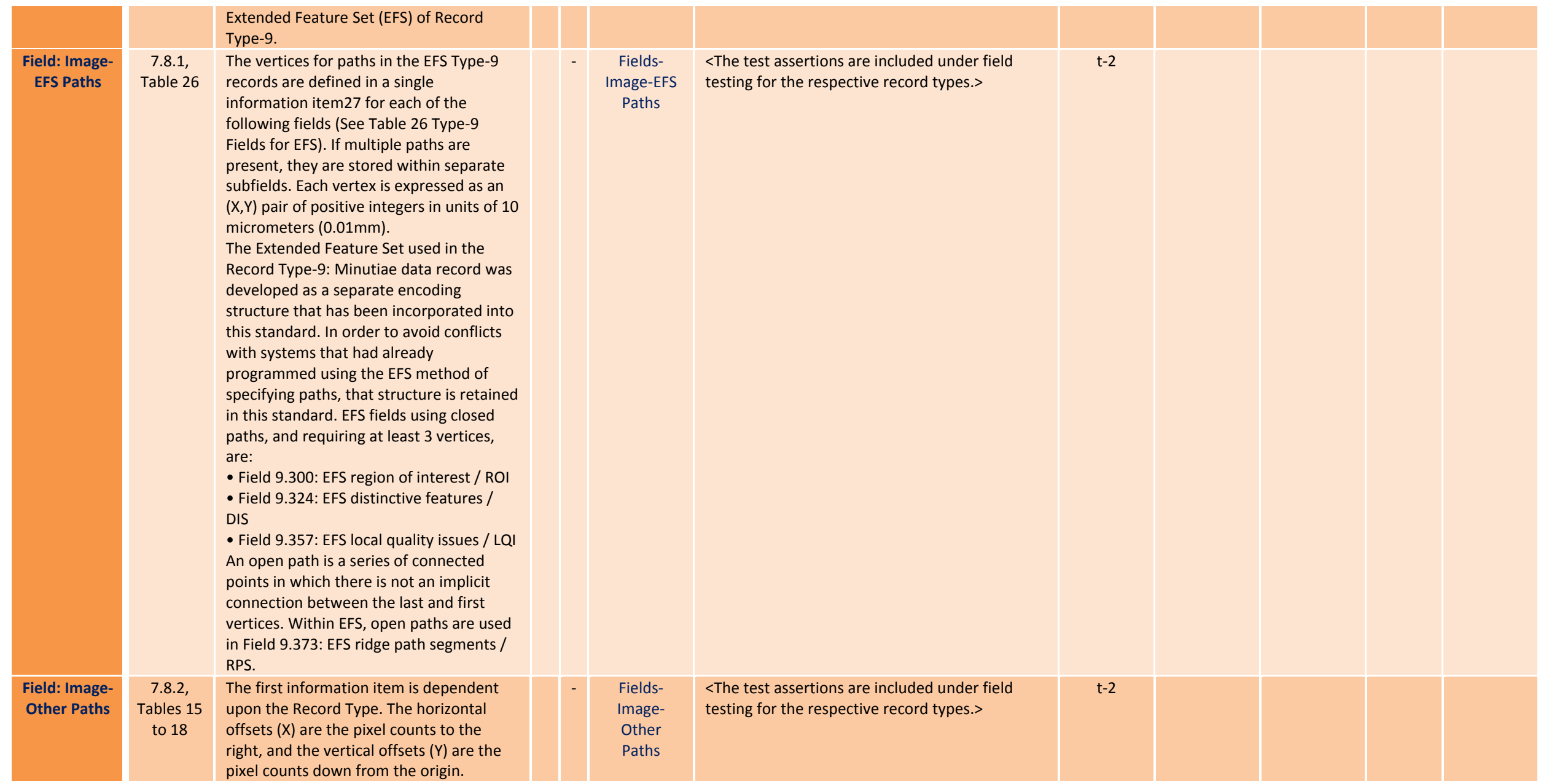


Table C.4 - Assertions for Record Type 1- Transaction Information Record

\begin{tabular}{|c|c|c|c|c|c|c|c|c|c|c|c|}
\hline $\begin{array}{l}\text { Requireme } \\
\text { nt } \\
\text { ID }\end{array}$ & $\begin{array}{l}\text { Referen } \\
\text { ce in } \\
\text { Base } \\
\text { Standar } \\
\quad \text { d }\end{array}$ & $\begin{array}{l}\text { Requirement } \\
\text { Summary }\end{array}$ & $\begin{array}{l}\text { L } \\
\text { e } \\
\text { v } \\
\text { e } \\
\text { I }\end{array}$ & $\begin{array}{l}\mathrm{S} \\
\mathrm{t} \\
\mathrm{a} \\
\mathrm{t} \\
\mathrm{u} \\
\mathrm{s}\end{array}$ & $\begin{array}{l}\text { Assertion } \\
\text { ID }\end{array}$ & $\begin{array}{l}\text { Test } \\
\text { Assertion }\end{array}$ & $\begin{array}{l}\text { Test } \\
\text { Note }\end{array}$ & $\begin{array}{l}\text { Implemen } \\
\text { tation } \\
\text { Support }\end{array}$ & $\begin{array}{l}\text { Supporte } \\
\text { d Range }\end{array}$ & $\begin{array}{l}\text { Test } \\
\text { Result }\end{array}$ & $\begin{array}{l}\text { XML, } \\
\text { Trad, } \\
\text { Both }\end{array}$ \\
\hline \multicolumn{12}{|c|}{ 8.1: Record Type-1: Transaction Information Record } \\
\hline $\begin{array}{l}\text { Transaction: } \\
\text { Type1 } \\
\text { Mandatory }\end{array}$ & 8.1 & $\begin{array}{l}\text { Record Type- } 1 \text { is mandatory. Only one } \\
\text { Type- } 1 \text { record is present per transaction. }\end{array}$ & & M & $\begin{array}{l}\text { Type1- } \\
\text { Mandatory }\end{array}$ & $\begin{array}{l}\text { <See Requirement ID "Transaction: Type1- } \\
\text { Occurrences"> }\end{array}$ & $\mathrm{t}-2$ & & & & \\
\hline $\begin{array}{l}\text { Record: } \\
\text { Type1- } \\
\text { Fields ASCII }\end{array}$ & 8.1 & $\begin{array}{l}\text { All of the fields in the Type- } 1 \text { record shall } \\
\text { be recorded using the 7-bit ASCII code }\end{array}$ & & M & $\begin{array}{l}\text { Type1- } \\
\text { Fields ASCII }\end{array}$ & <See Requirement ID “Record: Type1-ASCII”> & $\mathrm{t}-2$ & & & & \\
\hline \multirow[t]{7}{*}{$\begin{array}{l}\text { Field: Type1- } \\
\text { Subfield } \\
\text { Occurrence }\end{array}$} & \multirow[t]{7}{*}{ Table 19} & \multirow[t]{7}{*}{$\begin{array}{l}<\text { Table } 19 \text { specifies which fields contain } \\
\text { subfields as well as the number of } \\
\text { occurrences permitted.> }\end{array}$} & 1 & M & $\begin{array}{l}\text { Type1- } \\
\text { Subfields } \\
\text { Zero }\end{array}$ & $\begin{array}{l}\text { Count(Subfields in 1.[001, 002, } 004 \text { to } 006,009 \\
\text { to } 012,014]) \text { EQ } 0\end{array}$ & & & & & $\mathrm{~B}^{*}$ \\
\hline & & & 1 & M & $\begin{array}{l}1.003- \\
\text { Subfields }\end{array}$ & $\begin{array}{l}\text { Count(RS_Subfields in } 1.003 \text { ) GTE } 2 \\
\text { AND } \\
\text { Count(US_Subfields in } 1.003 \text { ) EQ } 2 \text { * } \\
\text { Count(RS_Subfields in 1.003) } \\
\text { AND } \\
\text { Count(RS_Subfields in 1.003) EQ } 1+ \\
\text { \{US_Subfield:2 in RS_Subfield:1 in } 1.003 \text { \} }\end{array}$ & & & & & $B^{*}$ \\
\hline & & & 1 & M & $\begin{array}{l}1.007- \\
\text { Subfields }\end{array}$ & Count(US_Subfields in 1.007 ) EQ 1 OR 2 & & & & & $B^{*}$ \\
\hline & & & 1 & M & $\begin{array}{l}\text { 1.008- } \\
\text { Subfields }\end{array}$ & Count(US_Subfields in 1.008 ) EQ 1 OR 2 & & & & & $B^{*}$ \\
\hline & & & 1 & 0 & $\begin{array}{l}\text { 1.013- } \\
\text { Subfields }\end{array}$ & Count(US_Subfields in 1.013 ) EQ 1 OR 2 & & & & & $\mathrm{~B}^{*}$ \\
\hline & & & 1 & 0 & $\begin{array}{l}\text { 1.015- } \\
\text { Subfields }\end{array}$ & Count(US_Subfields in 1.015 ) MO [1 to 3] & & & & & $\mathrm{B}^{*}$ \\
\hline & & & 1 & 0 & $\begin{array}{l}1.016- \\
\text { Subfields }\end{array}$ & $\begin{array}{l}\text { Count(RS_Subfields in 1.016) LTE } 99 \\
\text { AND } \\
\text { Count(US_Subfields in 1.016) EQ } 3 \text { * } \\
\text { Count(RS_Subfields in 1.016) }\end{array}$ & & & & & $\mathrm{B}^{*}$ \\
\hline Field: Type1- & Table 19 & $<$ Table 19 specifies the Condition Code for & 1 & M & Type1- & Present(1.001 to $1.005,1.007$ to $1.009,1.011$ & & & & & B \\
\hline
\end{tabular}




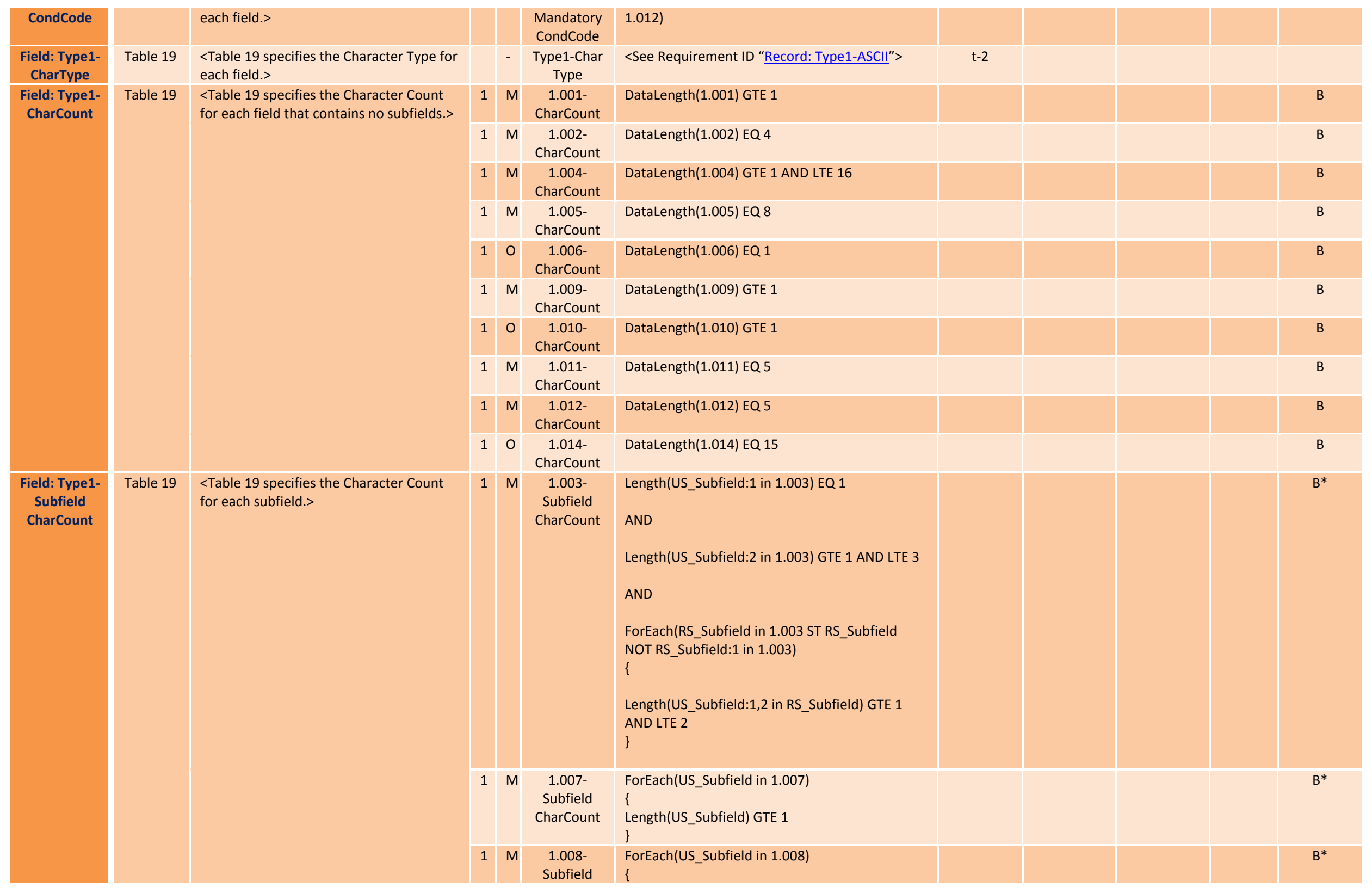




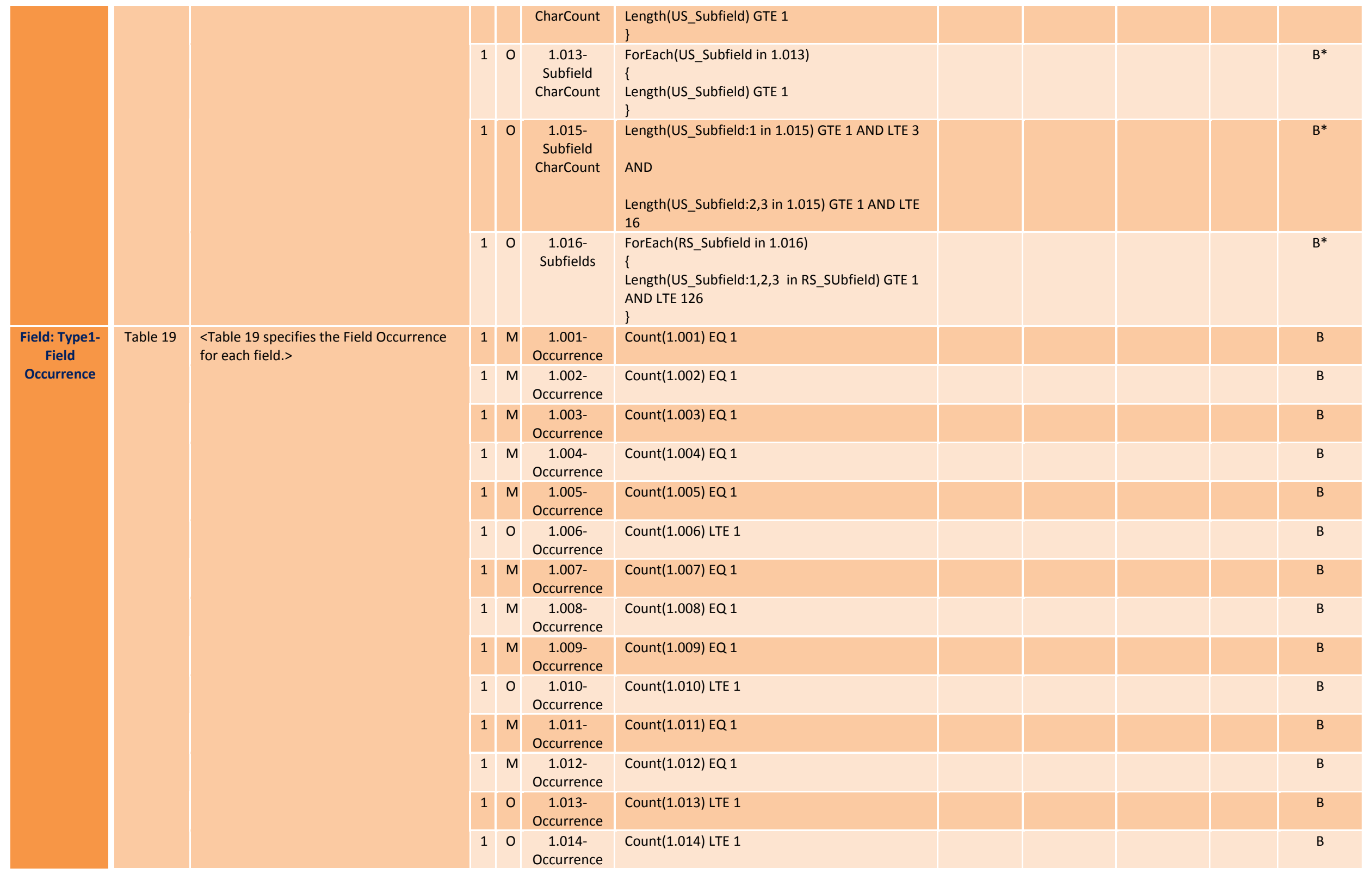




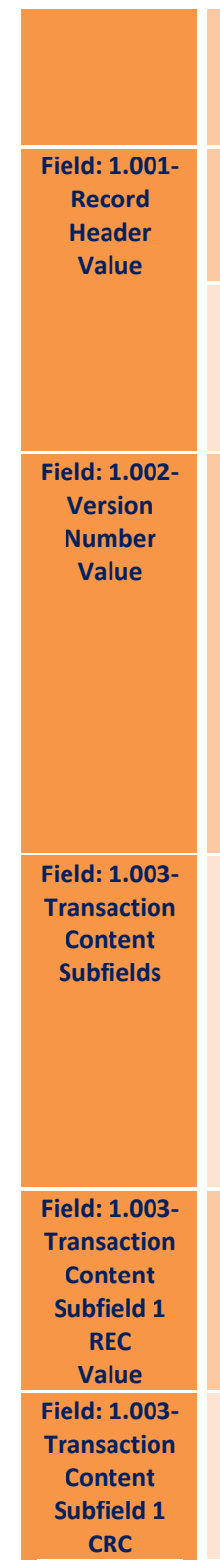

\begin{tabular}{|c|l|}
\hline 8.1 .1$, & $\begin{array}{l}\text { Field } 1.001 \text { Record header. In Traditional } \\
\text { encoding, this field contains the record } \\
\text { Table 19, } \\
\text { length in bytes (including all information } \\
\text { separators) }\end{array}$ \\
\hline 8.1 .1$, & $\begin{array}{l}\text { The XML name for the Type-1 record is } \\
\text { <itl:PackagelnformationRecord }, \text { and its } \\
\text { <biom:RecordCategoryCode> element } \\
\text { shall have a value of 01. }\end{array}$ \\
\hline C.10.1
\end{tabular}

8.1.2, This mandatory four-character ASCII

Table 19 value shall be used to specify the current version number of the standard

implemented by the software or system creating the transaction.

The format of this field shall consist of four numeric characters. The first two

characters shall specify the major version number. The last two characters shall be used to specify the minor revision

number. This version of the standard has the entry "0500"

8.1.3, This mandatory field shall list and identify Table 19 each of the records in the transaction by record type and its IDC value. It also specifies the order in which the remaining records shall appear in the file. It shall consist of two or more subfields. The first subfield shall relate to this Type- 1

Transaction record.

8.1.3,
Table 19

8.1.3,
Table 19
shall be " 1 ". This indicates that the first record in the transaction is a Type-1

record consisting of header information.

The second information item of this

subfield (content record count / CRC)

shall be the sum of the Type-2 through

Type- 99 records contained in this

transaction. This number is also equal to
$1 \quad 0 \quad 1.015-$ Occurrence

10 1.016Occurrence

2 M 1.001Record Header

1 M NIEM$1.001-$ Record Header

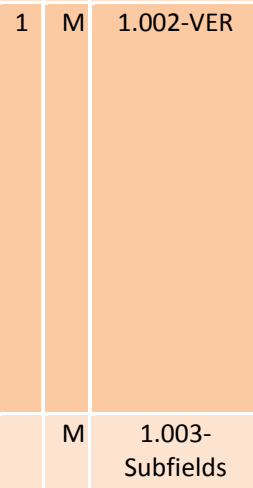
Count(1.016) LTE 1

<See Requirement ID “Field: xx.001-Record Header">

ForEach(XEIm(itl:PackagelnformationRecord ) \{

\{XEIm(biom:RecordCategoryCode)\} EQ ASCII(01)

\section{Count(1.015) LTE 1}

$\{1.002\}$ EQ ASCII(0500)

<See Requirement ID "Field: Type1-Subfield

$\mathrm{t}-2$

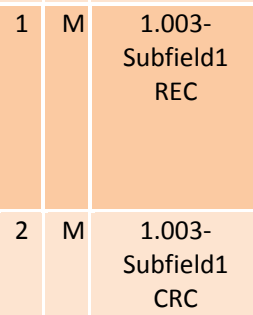

\{US_Subfield:1 in RS_Subfield:1 in 1.003\} EQ 1

\{US_Subfield:2 in 1.003\}

EQ

Count(Records in Transaction ST Type(Records)
Occurrence" and "Field: xx.002-IDC">

B
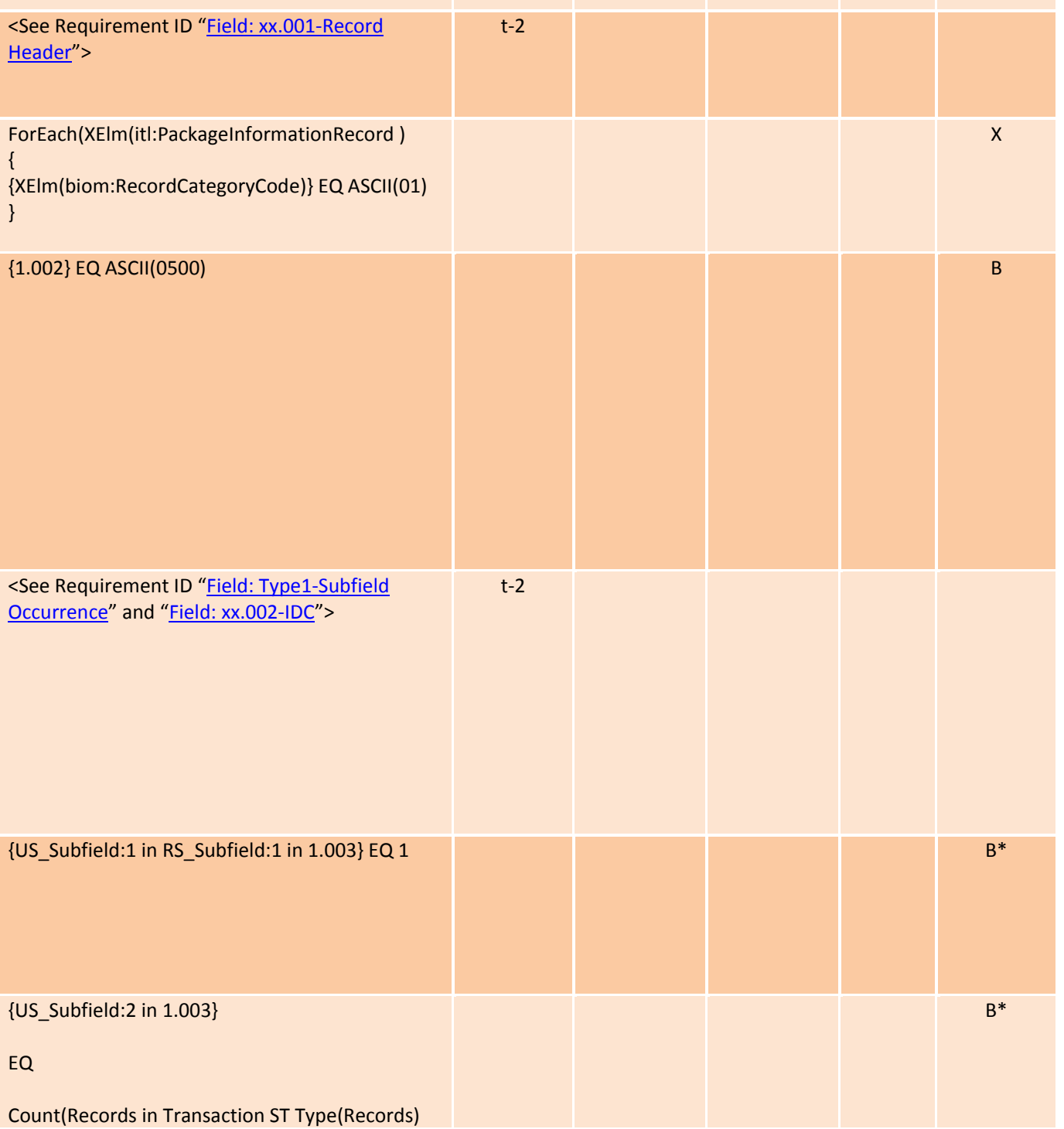


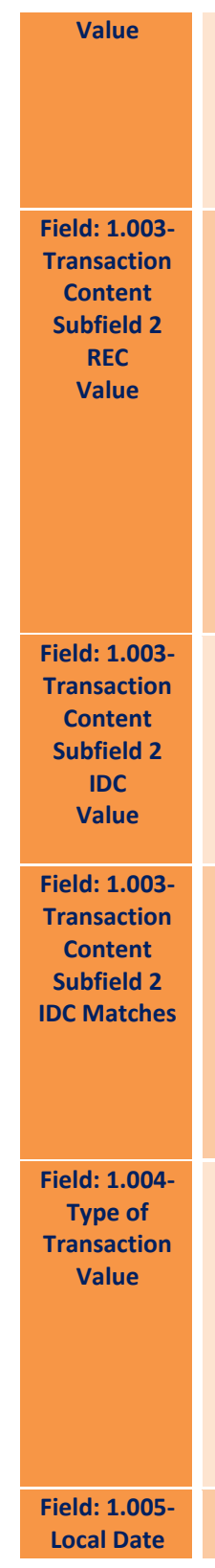

the count of the remaining subfields of Field 1.003 Transaction content / CNT. The maximum value for CRC is 999 .

MO [2 to 99])

EQ

Count(RS_Subfields in 1.003\} - 1

8.1.3, Each of the remaining subfields of Field Table 19, 1.003 Transaction content / CNT

Table 1 corresponds to a single Type-2 through Type-99 record contained in the

transaction. Two information items

shall comprise each of these subfields:

The first information item (record

category code / REC), shall contain a

number chosen from the "record

identifier" column of Table 1.

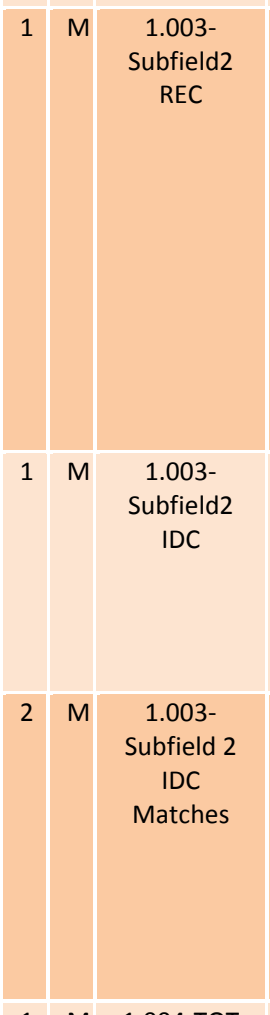

The second information item (information designation character / IDC) shall be an integer equal to or greater than zero and

less than or equal to 99 . See

Section 7.3.1.

8.1.3, IDC references are stated in Type-1 Field Table 19, 1.003 Transaction content / CNT and shal 7.3.1 be used to relate information items in the be used to relate information items in
CNT field of the Type-1 record to the other records in the transaction.

8.1 .4

Table 19

This mandatory field shall contain an

identifier, which designates the type of

transaction and subsequent processing

that this transaction should be given. This

shall be a maximum of 16 alphabetic

characters. The TOT shall be in

accordance with definitions provided by

the receiving agency.) Earlier versions of

this standard specifically restricted the

character length of TOT to 4 characters.

$81.5, \quad$ This mandatory field shall contain the

Table 19, local date that the transaction was
1 M 1.004-TOT

TRUE
ForEach(RS_Subfield in 1.003 ST RS_Subfield

NOT RS_Subfield:1 in 1.003)

\{

\{US_Subfield: 1 in RS_Subfield $\}$ MO $[2,4,7$ to 10 , 13 to $21,98,99$ ]

AND

Present(Record in Transaction ST Type(Record) EQ \{US_Subfield:1 in RS_Subfield $\}$

\}

ForEach(RS_Subfield in 1.003 ST NOT

\{

\{US_Subfield:2 in RS_Subfield\} MO [0 to 99]

\}

(RS Subfield in 1.003 ST NOT

RS_Subfield:1 in 1.003)

Present(Record ST Type(Record) EQ

\{US_Subfield:1 in RS_Subfield\} AND Record.002

US_Subfield:2 in RS_Subfield\})

1.005\} MO [ValidLocalDate]

1 M NIEM-

ForEach(XEIm(itl:PackagelnformationRecord))

\begin{tabular}{|l|l|l|l|}
\hline$t-6$ & & $T$ \\
\hline$t-6$ & $x$ \\
\hline
\end{tabular}




\begin{tabular}{|c|c|c|c|c|c|c|c|c|}
\hline Value & 7.7.2.3 & $\begin{array}{l}\text { submitted. The local date is recorded as } \\
\text { YYYYMMDD. Note that this may be a } \\
\text { different date than the corresponding } \\
\text { GMT, due to time zone differences. }\end{array}$ & & & 1.005-DAT & $\begin{array}{l}\{ \\
\{X E I m(n c: D a t e) \text { in XEIm(biom:TransactionDate) }\} \\
\text { MO [NIEM-ValidLocalDate] } \\
\}\end{array}$ & & \\
\hline $\begin{array}{l}\text { Field: } 1.006- \\
\text { Priority } \\
\text { Value }\end{array}$ & $\begin{array}{c}\text { 8.1.6 } \\
\text { Table } 19\end{array}$ & $\begin{array}{l}\text { This optional field shall contain a single } \\
\text { information character to designate the } \\
\text { urgency with which a response is desired. } \\
\text { The values shall range from } 1 \text { to } 9 \text {, with } 1 \\
\text { denoting the highest priority. The default } \\
\text { value shall be defined by the agency } \\
\text { receiving the transaction. }\end{array}$ & 1 & 0 & 1.006-PRY & $\{1.006\} \mathrm{MO}[1$ to 9$]$ & & B \\
\hline $\begin{array}{l}\text { Field: } 1.007- \\
\text { Destination } \\
\text { Agency } \\
\text { Value }\end{array}$ & $\begin{array}{c}8.1 .7 \\
\text { Table } 19\end{array}$ & $\begin{array}{l}\text { This mandatory field shall contain the } \\
\text { identifier of the administration or } \\
\text { organization designated to receive the } \\
\text { transmission. The size and data content of } \\
\text { this field shall be user-defined and in } \\
\text { accordance with the receiving agency. }\end{array}$ & & M & 1.007-DES & <See Requirement ID “Field: Agency Codes"> & $\mathrm{t}-2$ & \\
\hline $\begin{array}{l}\text { Field: } 1.008- \\
\text { Originating } \\
\text { Agency } \\
\text { Value }\end{array}$ & $\begin{array}{c}\text { 8.1.8 } \\
\text { Table } 19\end{array}$ & $\begin{array}{l}\text { This mandatory field shall contain the } \\
\text { identifier of the administration or } \\
\text { organization originating the transaction. } \\
\text { The size and data content of this field } \\
\text { shall be user-defined and in accordance } \\
\text { with the receiving agency. }\end{array}$ & & M & 1.008-ORG & <See Requirement ID "Field: Agency Codes"> & $\mathrm{t}-2$ & \\
\hline $\begin{array}{l}\text { Field: } 1.009- \\
\text { Transaction } \\
\text { Control } \\
\text { Number } \\
\text { Value }\end{array}$ & $\begin{array}{c}\text { 8.1.9, } \\
\text { Table } 19\end{array}$ & $\begin{array}{l}\text { This mandatory field shall contain the } \\
\text { transaction control number as assigned } \\
\text { by the originating agency. A unique } \\
\text { alphanumeric control number shall be } \\
\text { assigned to each transaction. For any } \\
\text { transaction that requires a response, the } \\
\text { respondent shall refer to this number in } \\
\text { communicating with the originating } \\
\text { agency. }\end{array}$ & 1 & M & 1.009-TCN & TRUE & & B \\
\hline $\begin{array}{l}\text { Field: } 1.010- \\
\text { Transaction } \\
\text { Control } \\
\text { Reference } \\
\text { Value }\end{array}$ & $\begin{array}{c}\text { 8.1.10, } \\
\text { Table } 19\end{array}$ & $\begin{array}{l}\text { This optional field shall be used for } \\
\text { responses that refer to the TCN of a } \\
\text { previous transaction involving an inquiry } \\
\text { or other action that required a response. }\end{array}$ & 1 & 0 & 1.010-TCR & TRUE & & B \\
\hline $\begin{array}{l}\text { Field: } 1.011- \\
\quad \text { Native } \\
\text { Scanning } \\
\text { Resolution } \\
\text { Value }\end{array}$ & $\begin{array}{c}\text { 8.1.11, } \\
\text { Table } 19\end{array}$ & $\begin{array}{l}\text { This mandatory field shall be set to } \\
\text { " } 00.00 \text { " if there are no Type- } 4 \text { records in } \\
\text { the transaction. } \\
\text { When there are Type- } 4 \text { records present, } \\
\text { this field is used to specify the native } \\
\text { scanning resolution of the friction ridge } \\
\text { image capture device. This field shall } \\
\text { specify the resolution in pixels per } \\
\text { millimeter. The resolution shall be } \\
\text { expressed as two numeric characters }\end{array}$ & & M & 1.011-NSR & <See Requirement IDs “Field: NSR Conditional”. $>$ & $\mathrm{t}-2$ & \\
\hline
\end{tabular}


followed by a decimal point and two

more numeric characters.

8.1.12, This mandatory field shall be set to

Table 19 "00.00" if there are no Type-4 records in

the transaction.

When there are Type- 4 records present,

this field specifies the nominal resolution for the image(s) being exchanged. This

field shall specify the resolution in pixels per millimeter.

The resolution shall be within the range $19.30 \mathrm{ppmm}$ (490 ppi) to $20.08 \mathrm{ppmm}$ (510 ppi).

8.1.13, The mandatory first information item

Table 19 (domain name / DNM) will uniquely

identify the agency, entity, or

implementation used for formatting the

fields in the Type-2 record. The default

value for the field shall be the North

American Domain implementation

(NORAM).

An optional second information item

(domain version number / DVN) shall

contain the unique version of the

particular implementation, such as 7.02 .

8.1.13, The domain name may only appear once

within a transaction.

This optional field provides a mechanism

10 1.013-DOM

<See Requirement ID “Field: Type4 NTR>

M 1.012-NTR

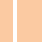

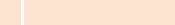

TRUE

Table 19 for expressing the date and time in terms

of universal Greenwich Mean Time (GMT)

units.
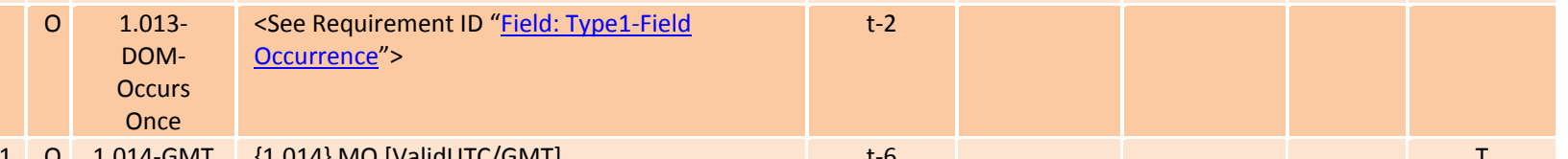

\begin{tabular}{l|l|l}
1 & 0 & $1.014-G M T$
\end{tabular}

$\{1.014\}$ MO [ValidUTC/GMT]

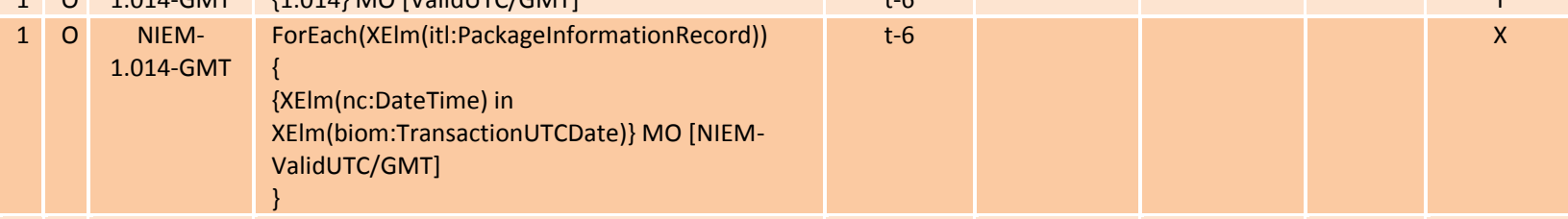

8.1.15, The first information item (character

Table 19, encoding index / CSI) is the three

Table 2 character identifier for the index number

1 M 1.015-DCS-

that references an associated character

encoding. See the "Character encoding

index" column of Table 2 for the valid

values for this information item.
$\Uparrow \quad$ CSI

\{US
B* 


\begin{tabular}{|c|c|c|c|c|c|c|c|c|}
\hline $\begin{array}{l}\text { Character } \\
\text { Encoding } \\
\text { Subfield } 2 \\
\text { CSN } \\
\text { Value }\end{array}$ & $\begin{array}{l}\text { Table 19, } \\
\text { Table } 2\end{array}$ & $\begin{array}{l}\text { encoding name / CSN) shall be the } \\
\text { "Character encoding name" associated } \\
\text { with that index number, taken from } \\
\text { Table } 2 \text {. }\end{array}$ & & & CSN & $\begin{array}{l}\text { \{US_Subfield:2 in } 1.015\} \text { EQ ASCII(ASCII) } \\
\text { AND } \\
\text { IF }\{\text { US_Subfield:1 in } 1.015\} \text { EQ } 2 \text { THEN } \\
\{\text { US_Subfield:2 in } 1.015\} \text { EQ ASCII(UTF-16) } \\
\text { AND } \\
\text { IF }\{\text { US_Subfield:1 in } 1.015\} \text { EQ } 3 \text { THEN } \\
\{\text { US_Subfield :2in } 1.015\} \text { EQ ASCII(UTF-8) } \\
\text { AND } \\
\text { IF }\{\text { US_Subfield:1 in } 1.015\} \text { EQ } 4 \text { THEN } \\
\{\text { US_Subfield:2 in } 1.015\} \text { EQ ASCII(UTF-32) }\end{array}$ & & \\
\hline $\begin{array}{l}\text { Field: } 1.015- \\
\text { Character } \\
\text { Encoding } \\
\text { Subfield } 3 \\
\text { CSV } \\
\text { Value }\end{array}$ & $\begin{array}{l}\text { 8.1.15, } \\
\text { Table 19, } \\
\text { Table } 2\end{array}$ & $\begin{array}{l}\text { The optional third information item } \\
\text { (character encoding version / CSV) is the } \\
\text { specific version of the character encoding } \\
\text { used. In the case of the use of UTF- } 8 \text {, the } \\
\text { third optional information item may be } \\
\text { used to hold the specific version used, so } \\
\text { that the display terminal can be switched } \\
\text { to the correct font family. }\end{array}$ & 1 & $\begin{array}{l}0 \\
\Uparrow\end{array}$ & $\begin{array}{c}\text { 1.015-DCS- } \\
\text { CSV }\end{array}$ & TRUE & & B* \\
\hline $\begin{array}{l}\text { Field: } 1.015- \\
\text { Character } \\
\text { Encoding } \\
\text { User } \\
\text { Defined }\end{array}$ & & $\begin{array}{l}\text { This optional field specifies the character } \\
\text { encoding that may appear within this } \\
\text { transaction for data with the character } \\
\text { type listed as " } U \text { " or 'user-defined' in the } \\
\text { record format tables. }\end{array}$ & 3 & 0 & $\begin{array}{l}\text { 1.015-DCS- } \\
\text { User } \\
\text { Defined } \\
\text { Encoding }\end{array}$ & $<$ Not Tested. $>$ & $\mathrm{t}-1, \mathrm{t}-4$ & B \\
\hline $\begin{array}{l}\text { Field: 1.016- } \\
\text { Application } \\
\text { Profile } \\
\text { Specification } \\
\text { s } \\
\text { Value }\end{array}$ & $\begin{array}{c}\text { 8.1.16, } \\
\text { Table } 19\end{array}$ & $\begin{array}{l}\text { There may be multiple subfields, each } \\
\text { designating an application profile to } \\
\text { which this transaction conforms Each } \\
\text { subfield shall consist of three mandatory } \\
\text { information items: } \\
\text { The first information item (application } \\
\text { profile organization / APO) will uniquely } \\
\text { identify the agency or entity responsible } \\
\text { for the specification. } \\
\text { The second information item (application } \\
\text { profile name / APN) shall contain the } \\
\text { name of the specification. } \\
\text { The third information item (application } \\
\text { profile version number / APV) shall }\end{array}$ & 1 & 0 & 1.016-APS & TRUE & & B* \\
\hline
\end{tabular}


contain the specific version of the

specification.

Field: 1.016-

specifications. See Section 6.

If multiple Application Profile

Specifications are included in this field,

the specifications must be compatib

with each other: this transaction must be

in compliance with all of the cited

\begin{tabular}{|l|l|l|}
3 & 0 & 1.016
\end{tabular}

$<$ Not Tested.>

$s$ $t-1, t-3$ 
Table C.5 - Assertions for Record Type 3 - Deprecated

\begin{tabular}{|c|c|c|c|c|c|c|c|c|c|c|c|}
\hline $\begin{array}{l}\text { Requireme } \\
\text { nt } \\
\text { ID }\end{array}$ & $\begin{array}{c}\text { Referen } \\
\text { ce in } \\
\text { Base } \\
\text { Standar } \\
\text { d }\end{array}$ & $\begin{array}{l}\text { Requirement } \\
\text { Summary }\end{array}$ & $\begin{array}{l}\text { L } \\
\text { e } \\
\text { v } \\
\text { e } \\
\text { I }\end{array}$ & \begin{tabular}{l|l|} 
S & \\
t & \\
$\mathrm{a}$ & \\
$\mathrm{t}$ & \\
$\mathrm{u}$ & \\
$\mathrm{s}$
\end{tabular} & $\begin{array}{l}\text { Assertion } \\
\text { ID }\end{array}$ & $\begin{array}{l}\text { Test } \\
\text { Assertion }\end{array}$ & $\begin{array}{l}\text { Test } \\
\text { Note }\end{array}$ & $\begin{array}{l}\text { Implemen } \\
\text { tation } \\
\text { Support }\end{array}$ & $\begin{array}{c}\text { Supporte } \\
\text { d Range }\end{array}$ & $\begin{array}{c}\text { Test } \\
\text { Result }\end{array}$ & $\begin{array}{l}\text { Applicab } \\
\text { ility }\end{array}$ \\
\hline \multicolumn{12}{|c|}{ 8.3: Record Type-3: DEPRECATED } \\
\hline \multirow[t]{2}{*}{$\begin{array}{l}\text { Transaction: } \\
\text { Type3 Zero } \\
\text { Occurrences }\end{array}$} & \multirow[t]{2}{*}{8.3} & \multirow[t]{2}{*}{$\begin{array}{l}\text { No instances of Record Type- } 3 \text { shall be } \\
\text { included in a transaction conformant with } \\
\text { this version of the standard. }\end{array}$} & 2 & M & $\begin{array}{c}\text { Type3-Zero } \\
\text { Occurrence } \\
\text { s }\end{array}$ & $\begin{array}{l}\text { ForEach(Record in Transaction) } \\
\{ \\
\text { Type(Record) NEQ } 3 \\
\}\end{array}$ & & & & & $\mathrm{T}$ \\
\hline & & & 2 & M & $\begin{array}{l}\text { NIEM- } \\
\text { Type3-Zero } \\
\text { Occurrence } \\
\text { s }\end{array}$ & $\begin{array}{l}<\text { An invalid record type will cause a parsing error } \\
\text { in XML because no Record Element Tag is } \\
\text { defined (see Table } 97 \text { ).> }\end{array}$ & & & & & $x$ \\
\hline
\end{tabular}


Table C.6 - Assertions for Record Type 4 - Grayscale Fingerprint Image

\begin{tabular}{|c|c|c|c|c|c|c|c|c|c|c|c|}
\hline $\begin{array}{l}\text { Requireme } \\
\text { nt } \\
\text { ID }\end{array}$ & $\begin{array}{l}\text { Referen } \\
\text { ce in } \\
\text { Base } \\
\text { Standar } \\
\quad \text { d }\end{array}$ & $\begin{array}{l}\text { Requirement } \\
\text { Summary }\end{array}$ & $\begin{array}{l}\text { L } \\
\text { e } \\
\text { v } \\
\text { e } \\
\text { I }\end{array}$ & $\begin{array}{l}\mathrm{S} \\
\mathrm{t} \\
\mathrm{a} \\
\mathrm{t} \\
\mathrm{u} \\
\mathrm{s}\end{array}$ & $\begin{array}{l}\text { Assertion } \\
\text { ID }\end{array}$ & $\begin{array}{l}\text { Test } \\
\text { Assertion }\end{array}$ & $\begin{array}{l}\text { Test } \\
\text { Note }\end{array}$ & $\begin{array}{l}\text { Implemen } \\
\text { tation } \\
\text { Support }\end{array}$ & $\begin{array}{l}\text { Supporte } \\
\text { d Range }\end{array}$ & $\begin{array}{l}\text { Test } \\
\text { Result }\end{array}$ & $\begin{array}{l}\text { Applicab } \\
\text { ility }\end{array}$ \\
\hline \multicolumn{12}{|c|}{ 8.4: Record Type-4: Grayscale fingerprint image } \\
\hline $\begin{array}{l}\text { Record: } \\
\text { Type4 Scan } \\
\text { Resolution } \\
\text { 500ppi }\end{array}$ & 8.4 & $\begin{array}{l}\text { The Type- } 4 \text { record is based on the use of a } \\
\text { captured fingerprint image obtained using } \\
\text { a class scanning resolution of } 500 \text { ppi. } \\
\text { (See Section } 7.7 .6 \text { ). It shall not be used for } \\
\text { other than } 500 \text { ppi. class images. }\end{array}$ & & M & $\begin{array}{l}\text { Type4-Scan } \\
\text { Resolution } \\
\text { 500ppi }\end{array}$ & <See Requirement ID “Field: Type4 NTR"> & $\mathrm{t}-2$ & & & & \\
\hline $\begin{array}{l}\text { Record: } \\
\text { Type4 Image } \\
\text { Compressio } \\
\text { n WSQ }\end{array}$ & 8.4 & $\begin{array}{l}\text { All images shall be compressed using } \\
\text { WSQ. }\end{array}$ & & M & $\begin{array}{l}\text { Type4-CGA } \\
\text { WSQ Only }\end{array}$ & $\begin{array}{l}<\text { See Requirement IDs "Field: 4.008-Compression } \\
\text { Algorithm Value" and "Field: } 4.009 \text {-Image Data } \\
\underline{\text { Valid">. }}\end{array}$ & $\mathrm{t}-2$ & & & & \\
\hline $\begin{array}{l}\text { Field: Type4- } \\
\text { CondCode }\end{array}$ & $\begin{array}{l}\text { Table } 21 \\
\text { Table } 95\end{array}$ & $\begin{array}{l}<\text { Table } 21 \text { specifies the Condition Code for } \\
\text { each field.> }\end{array}$ & 1 & M & $\begin{array}{l}\text { Type4- } \\
\text { Mandatory } \\
\text { CondCode }\end{array}$ & Present(4.001 to 4.009$)$ & & & & & B \\
\hline $\begin{array}{l}\text { Field: Type4- } \\
\text { CharType }\end{array}$ & $\begin{array}{l}\text { Table } 21 \\
\text { Table } 95\end{array}$ & $\begin{array}{l}\text { Traditional format requires the data in } \\
\text { binary form (not text) with a fixed byte } \\
\text { length. }\end{array}$ & 3 & M & $\begin{array}{l}\text { Type4-Char } \\
\text { Type }\end{array}$ & $\begin{array}{l}<\text { Not tested directly, but Type } 4 \text { is parsed as } \\
\text { unnumbered binary data for Traditional } \\
\text { encoding }>\end{array}$ & $\mathrm{t}-13$ & & & & $\mathrm{~T}$ \\
\hline \multirow[t]{6}{*}{$\begin{array}{l}\text { Field: Type4- } \\
\text { ByteCount }\end{array}$} & \multirow[t]{6}{*}{$\begin{array}{l}\text { Table 21, } \\
\text { Table } 95\end{array}$} & \multirow[t]{6}{*}{$\begin{array}{l}\text { <Table } 95 \text { specifies the Byte Count for } \\
\text { each field.> }\end{array}$} & 1 & M & $\begin{array}{c}\text { 4.001- } \\
\text { ByteCount }\end{array}$ & Length(4.001) EQ 4 & & & & & $\mathrm{~T}$ \\
\hline & & & 1 & M & $\begin{array}{l}\text { NIEM- } \\
4.001- \\
\text { ByteCount }\end{array}$ & $\begin{array}{l}\text { ForEach(XEIm(itl:PackageHighResolutionGrayscal } \\
\text { elmageRecord)) } \\
\{ \\
\text { Length(XEIm(biom:RecordCategoryCode) EQ } 2 \\
\text { \} }\end{array}$ & & & & & $\mathrm{x}$ \\
\hline & & & 1 & M & $\begin{array}{c}4.002- \\
\text { ByteCount }\end{array}$ & Length(4.002) EQ 1 & & & & & $\mathrm{~T}$ \\
\hline & & & 1 & M & $\begin{array}{l}\text { NIEM- } \\
4.002- \\
\text { ByteCount }\end{array}$ & 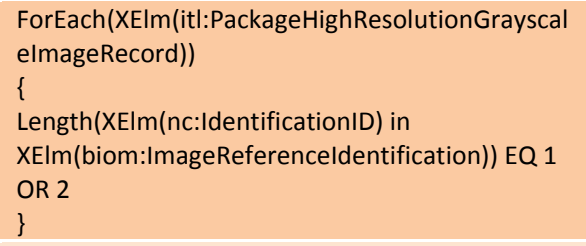 & & & & & $\mathrm{x}$ \\
\hline & & & 1 & M & $\begin{array}{c}4.003- \\
\text { ByteCount }\end{array}$ & Length(4.003) EQ 1 & & & & & $\mathrm{~T}$ \\
\hline & & & 1 & M & $\begin{array}{l}\text { NIEM- } \\
4.003-\end{array}$ & $\begin{array}{l}\text { ForEach(XEIm(itl:PackageHighResolutionGrayscal } \\
\text { elmageRecord)) }\end{array}$ & & & & & $\mathrm{x}$ \\
\hline
\end{tabular}



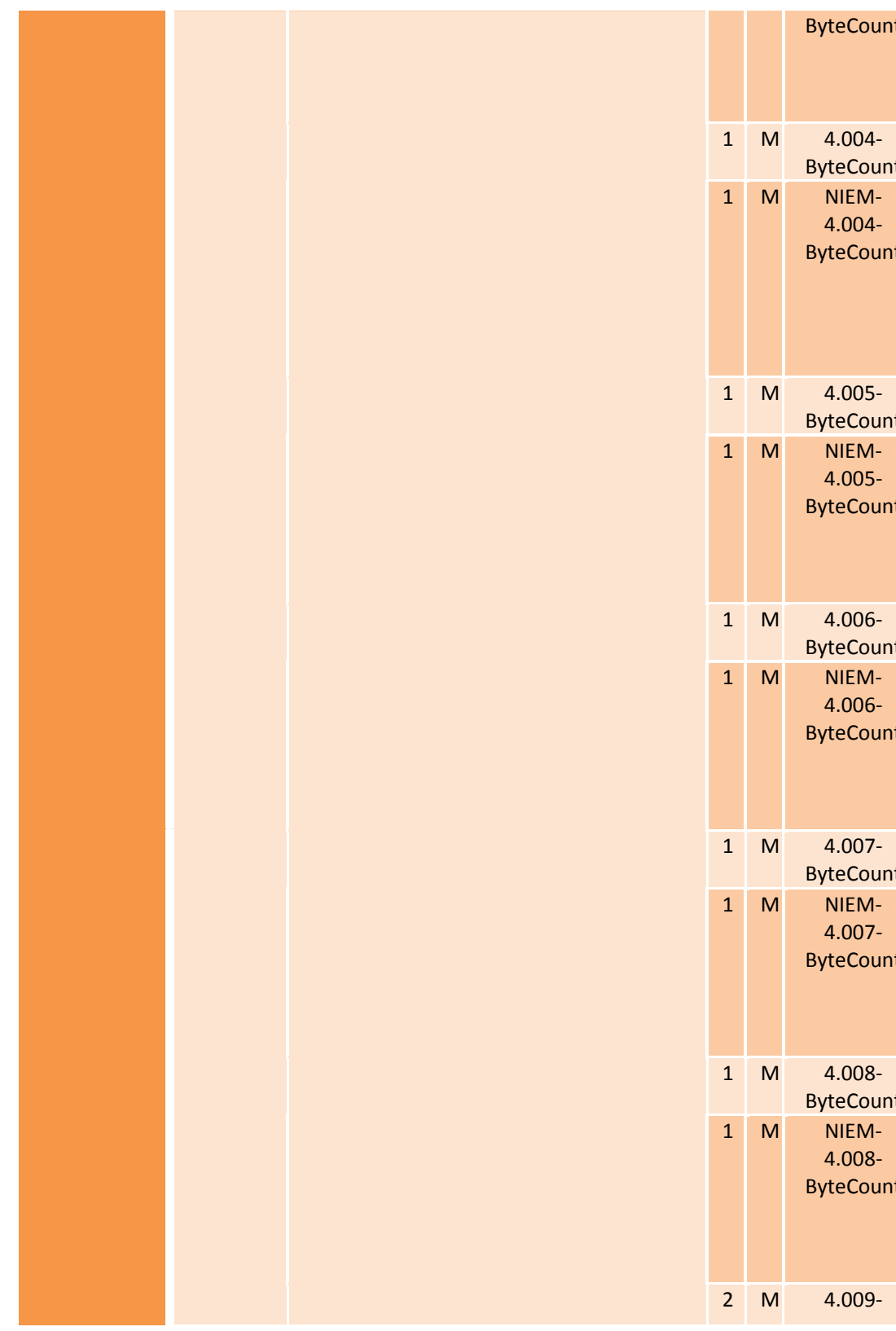

Length(XEIm(biom:FingerprintImagelmpressionC aptureCategoryCode)) EQ 1 OR 2

\}

$1 \quad M \quad \begin{gathered}4.004- \\ \text { ByteCount }\end{gathered}$

Length(4.004) EQ 6

1 M NIEM- $\quad$ ForEach(XEIm(itl):PackageHighResolutionGrayscal

4.004- elmageRecord))

ByteCount

Length(All(XEIm(biom:FingerPositionCode) in

XEIm(biom:FingerprintImagePosition))) MO [1 to

3]

1 M 4.005-

ength(4.005) EQ 1

1 M NIEM- ForEach(XElm(itl:PackageHighResolutionGrayscal

4.005- elmageRecord)

ByteCount

Length(XEIm(biom:CaptureResolutionCode) in

XEIm(biom:ImageCaptureDetail)) EQ 1

\}

1 M 4.006-

Length(4.006) EQ 2

ByteCount

1 M NIEM- $\quad$ ForEach(XElm(itl:PackageHighResolutionGrayscal

4.006- elmageRecord))

ByteCount

Length(XEIm(biom:ImageHorizontalLineLengthPi xelQuantity)) MO [2 to 5]

\}

1 M 4.007-

Length(4.007) EQ 2

ByteCount

1 M NIEM- $\quad$ ForEach(XElm(itl:PackageHighResolutionGrayscal 4.007- elmageRecord))

ByteCount

Length(XEIm(biom:ImageVerticalLineLengthPixel Quantity)) MO [2 to 5] \}

1 M 4.008-

Length(4.008) EQ 1

ByteCount

1 M NIEM- ForEach(XElm(itl:PackageHighResolutionGrayscal 4.008- elmageRecord))

ByteCount \{

Length(XEIm(biom:ImageCompressionAlgorithm Code)) EQ 1 \}

2 M 4.009-

Length(4.009) EQ $\{4.001\}-18$ 


\begin{tabular}{|c|c|c|c|c|c|c|c|c|}
\hline & & & & & ByteCount & & & \\
\hline & & & 1 & M & $\begin{array}{l}\text { NIEM- } \\
4.009- \\
\text { ByteCount }\end{array}$ & $\begin{array}{l}\text { ForEach(XEIm(itl):PackageHighResolutionGrayscal } \\
\text { elmageRecord)) } \\
\{ \\
\text { Length(XEIm(nc:BinaryBase64Object)) GTE } 1 \\
\text { \} }\end{array}$ & & $x$ \\
\hline \multirow[t]{2}{*}{$\begin{array}{l}\text { Field: } 4.001- \\
\text { Record } \\
\text { Header } \\
\text { Value }\end{array}$} & $\begin{array}{l}8.4 .1 \\
\text { Table 21, } \\
7.1\end{array}$ & $\begin{array}{l}\text { Field } 4.001 \text { Record header. In Traditional } \\
\text { encoding, this field contains the record } \\
\text { length in bytes (including all information } \\
\text { separators) }\end{array}$ & & M & $\begin{array}{l}4.001- \\
\text { Record } \\
\text { Header }\end{array}$ & $\begin{array}{l}\text { <See Requirement ID "Field: xx.001-Record } \\
\text { Header" }\end{array}$ & $\mathrm{t}-2$ & \\
\hline & $\begin{array}{l}\text { 8.4.1 } \\
\text { C.10.4 }\end{array}$ & $\begin{array}{l}\text { The XML name for the Type-4 record is } \\
<\text { itl:PackageHighResolutionGrayscalelmag } \\
\text { eRecord>, and its } \\
<\text { biom:RecordCategoryCode> element } \\
\text { shall } \\
\text { have a value of "04". }\end{array}$ & 1 & M & $\begin{array}{l}\text { NIEM- } \\
4.001- \\
\text { Record } \\
\text { Header }\end{array}$ & $\begin{array}{l}\text { ForEach(XEIm(itl:PackageHighResolutionGrayscal } \\
\text { elmageRecord ) } \\
\{ \\
\{\text { XElm(biom:RecordCategoryCode)\} EQ ASCII(04) } \\
\}\end{array}$ & & $\mathrm{x}$ \\
\hline $\begin{array}{l}\text { Field: } 4.002- \\
\text { Information } \\
\text { Designation } \\
\text { Character } \\
\quad \text { Value }\end{array}$ & $\begin{array}{c}\text { 8.4.2 } \\
\text { Table 21, } \\
\text { 7.3.1 }\end{array}$ & $\begin{array}{l}\text { This mandatory field shall be the IDC of } \\
\text { this Type- } 4 \text { record as found in the } \\
\text { information item IDC of Field } 1.003 \\
\text { Transaction content/CNT. }\end{array}$ & & M & 4.002-IDC & $\begin{array}{l}<\text { See Requirement IDs "Field: xx.002-IDC and } \\
\text { "Field: 1.003-Transaction Content Subfield } 2 \text { IDC } \\
\text { Matches" > }\end{array}$ & $\mathrm{t}-2$ & \\
\hline $\begin{array}{l}\text { Field: } 4.003- \\
\text { Impression } \\
\text { Type Value }\end{array}$ & $\begin{array}{l}\text { 8.4.3 } \\
\text { Table 21, } \\
\text { 7.7.4.1 }\end{array}$ & $\begin{array}{l}\text { This mandatory field shall indicate the } \\
\text { manner by which the fingerprint was } \\
\text { obtained. See Section 7.7.4.1 for details. }\end{array}$ & 1 & M & 4.003-IMP & $\{4.003\} \mathrm{MO}[0$ to $3,8,20$ to 29,36 to 39$]$ & & B \\
\hline $\begin{array}{l}\text { Field: 4.004- } \\
\text { Friction }\end{array}$ & $\begin{array}{l}\text { 8.4.4, } \\
\text { Table 21, }\end{array}$ & $\begin{array}{l}\text { This mandatory field shall contain the } \\
\text { decimal code number corresponding to }\end{array}$ & 1 & M & 4.004-FGP & Bytes(4.004) MO [0x00 to 0xOA, 0xFF] & & $\mathrm{T}$ \\
\hline $\begin{array}{l}\text { Ridge } \\
\text { Generalized } \\
\text { Position } \\
\text { Value }\end{array}$ & & $\begin{array}{l}\text { the finger position and shall be taken } \\
\text { from Table } 6 \text { (only finger numbers } 0-10 \\
\text { apply to Type- } 4 \text { ). Up to five additional } \\
\text { finger positions shall be referenced by } \\
\text { entering the alternate finger positions } \\
\text { using the same format. If fewer than five } \\
\text { finger position references are to be used, } \\
\text { the unused position references shall be } \\
\text { filled with } 255 \text {. Six values shall be entered } \\
\text { in each record. }\end{array}$ & 1 & M & $\begin{array}{l}\text { NIEM- } \\
4.004-F G P\end{array}$ & $\begin{array}{l}\text { ForEach(XEIm(itl:PackageHighResolutionGrayscal } \\
\text { elmageRecord ) } \\
\{ \\
\{\text { All(XEIm(biom:FingerPositionCode) in } \\
\text { XElm(biom:FingerprintlmagePosition))\} MO [0 to } \\
\text { 10, 255] } \\
\}\end{array}$ & & $\mathrm{x}$ \\
\hline $\begin{array}{l}\text { Field: } 4.005- \\
\text { Image } \\
\text { Scanning } \\
\text { Resolution } \\
\text { Value }\end{array}$ & $\begin{array}{l}\text { 8.4.5, } \\
\text { Table } 21\end{array}$ & $\begin{array}{l}\text { The mandatory ISR field relates to the } \\
\text { scanning resolution of this image. } \\
\text { Previous versions of this standard stated } \\
\text { that } 0 \text { in this field represents the } \\
\text { 'minimum scanning resolution.' The } \\
\text { minimum scanning resolution was } \\
\text { defined in ANSI/NIST-ITL } 1-2007 \text { as "19.69 } \\
\text { ppmm plus or minus } 0.20 \text { ppmm ( } 500 \text { ppi } \\
\text { plus or minus } 5 \text { ppi)." Therefore, if the } \\
\text { image scanning resolution corresponds to } \\
\text { the Appendix F certification level (See }\end{array}$ & 2 & M & 4.005-ISR & $\begin{array}{l}\text { IF }\{1.011\} \text { LTE } 19.49 \text { OR GTE } 19.89 \text { THEN } \\
\{4.005\} \text { EQ } 1 \\
\text { ELSE } \\
\{4.005\} \text { EQ } 0\end{array}$ & & B \\
\hline
\end{tabular}




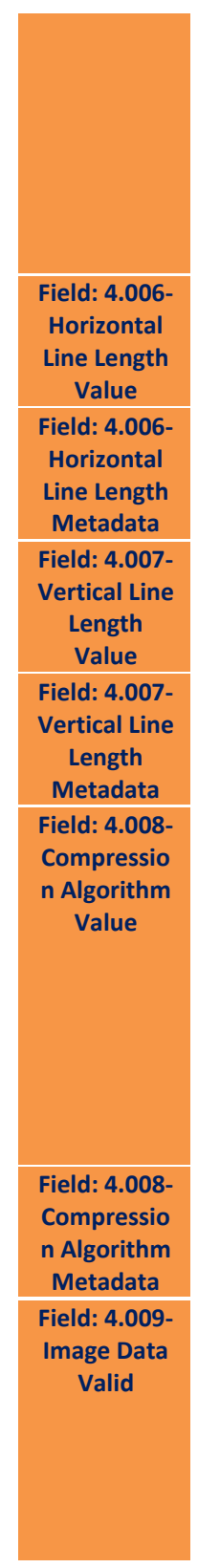

Table

11 Class resolutions with maximum

variance), a 0 shall be entered in this field.

A value of 1 is entered if the actual

scanning resolution (outside of the

Appendix $\mathrm{F}$ certification range) is

specified in Field 1.011 Native scanning resolution / NSR.

8.4.6, This mandatory field shall contain the

Table 21 number of pixels on a single horizontal line of the transmitted image.

8.4.6, <The HLL is verified by checking the image

Table 21, metadata if compression is used. $>$

2 M 4.006-HLL

WSQ

Standard

8.4.7,

This mandatory field shall contain the

Table 21

number of pixels on a single horizontal

line of the transmitted image.

8.4.7, <The VLL is verified by checking the image

Table 21 metadata if compression is used.>

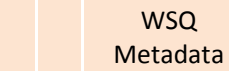

WSQ

Metadata

M 4.006-HLL

<See Requirement ID "Field: Image HLL Value">

IF $\{4.008\}$ EQ 1 THEN

\{4.006\} EQ \{Image Width-WSQ\}
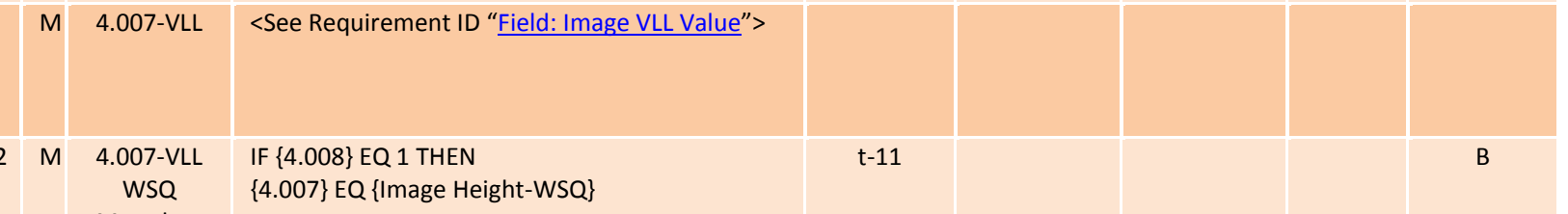

IF $\{4.008\}$ EQ 1 THEN

$\mathrm{t}-11$

4.007\} EQ \{Image Height-WSQ $\}$

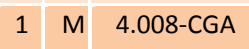

$\{4.008\}$ EQ 0 OR 1

$\mathrm{t}-98$

8.4.8, WSO

Table 21

This is a mandatory field, used to specify the type of compression algorithm used.

A zero denotes no compression.

Otherwise, the contents shall be a

number allocated to the particular

compression technique used by the

interchange parties. The specific code for

each algorithm can be found in Table 12.

8.4.8, <The CGA is verified by checking the

image metadata for the compression type

signature if compression is used.>

2 M 4.008-CGA

WSQ

Metadata

8.4.9 This is a mandatory field. Each pixel of the uncompressed grayscale image shall be quantized to eight bits (256 gray levels) contained in a single byte. For the

exchange of an uncompressed binary

image, eight pixels shall be left justified and packed into a single unsigned byte. The most significant bit of the byte shal

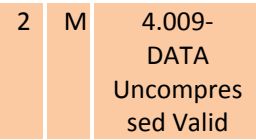

2 M 4.009DATA WSQ
Valid

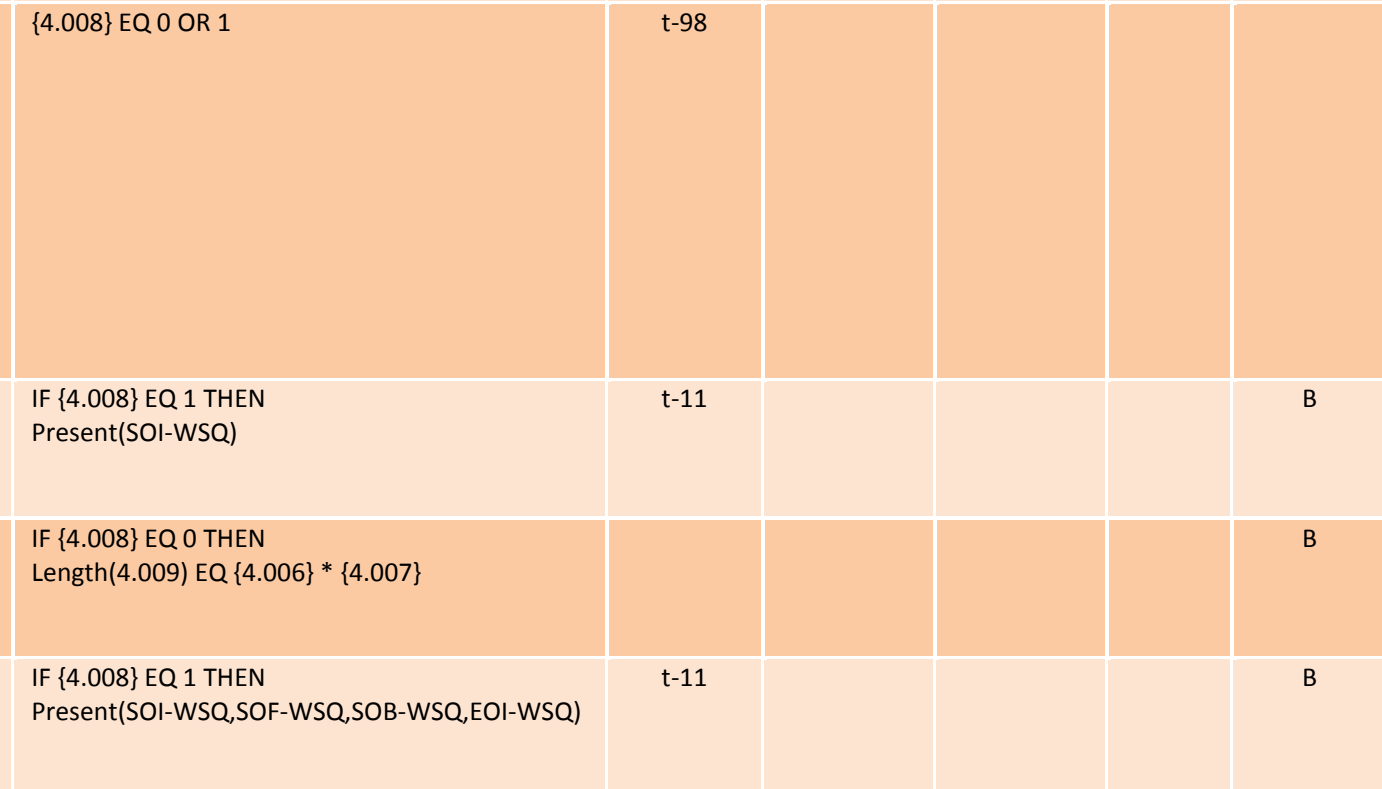




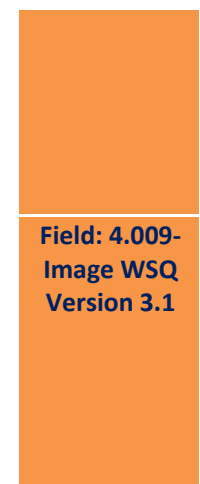

be the first of the eight pixels scanned. If compression is used, the pixel data shall be compressed in accordance with the compression technique specified in the Field 4.008: Compression algorithm /

CGA / BCA.

8.4.9, Wavelet Scalar Quantization (WSQ) shall

7.7.9.1 be used for compressing grayscale friction

ridge data at 500 ppi class. Only version

3.1 or higher shall be used for

3.1 or higher shall be used for

500 ppi class with a platen area of 2

inches or greater in height. WSQ shall not

be used for other than the 500 ppi class.

\begin{tabular}{l|l|l|l}
2 & M & $\begin{array}{c}4.009- \\
\text { DATA WSO }\end{array}$ & IF $\{4.008\}$ EQ 1 THEN \\
\{Encoder Version $\}$ EQ 2
\end{tabular}

Version

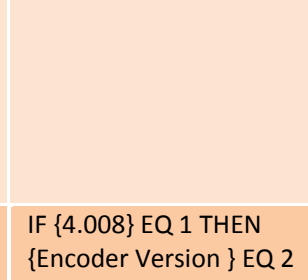

$\mathrm{t}-11$ 
Table C.7 - Assertions for Record Type 5 - Deprecated

\begin{tabular}{|c|c|c|c|c|c|c|c|c|c|c|c|}
\hline $\begin{array}{l}\text { Requireme } \\
\text { nt } \\
\text { ID }\end{array}$ & $\begin{array}{c}\text { Referen } \\
\text { ce in } \\
\text { Base } \\
\text { Standar } \\
\text { d }\end{array}$ & $\begin{array}{l}\text { Requirement } \\
\text { Summary }\end{array}$ & $\begin{array}{l}\text { L } \\
\text { e } \\
\text { v } \\
\text { e } \\
\text { I }\end{array}$ & \begin{tabular}{l|l|} 
s & \\
$t$ & \\
$a$ & \\
$t$ & \\
$u$ & \\
\end{tabular} & $\begin{array}{l}\text { Assertion } \\
\text { ID }\end{array}$ & $\begin{array}{l}\text { Test } \\
\text { Assertion }\end{array}$ & $\begin{array}{l}\text { Test } \\
\text { Note }\end{array}$ & $\begin{array}{l}\text { Implemen } \\
\text { tation } \\
\text { Support }\end{array}$ & $\begin{array}{c}\text { Supporte } \\
\text { d Range }\end{array}$ & $\begin{array}{c}\text { Test } \\
\text { Result }\end{array}$ & $\begin{array}{c}\text { Applicab } \\
\text { ility }\end{array}$ \\
\hline \multicolumn{12}{|c|}{ 8.5: Record Type-5: DEPRECATED } \\
\hline \multirow[t]{2}{*}{$\begin{array}{l}\text { Transaction: } \\
\text { Type5 Zero } \\
\text { Occurrences }\end{array}$} & \multirow[t]{2}{*}{8.5} & \multirow[t]{2}{*}{$\begin{array}{l}\text { No instances of Record Type- } 5 \text { shall be } \\
\text { included in a transaction conformant with } \\
\text { this version of the standard. }\end{array}$} & 2 & M & $\begin{array}{c}\text { Type5-Zero } \\
\text { Occurrence } \\
\text { s }\end{array}$ & $\begin{array}{l}\text { ForEach(Record in Transaction) } \\
\{ \\
\text { Type(Record) NEQ } 5 \\
\}\end{array}$ & & & & & $\mathrm{T}$ \\
\hline & & & 2 & M & $\begin{array}{l}\text { NIEM- } \\
\text { Type5-Zero } \\
\text { Occurrence } \\
\text { s }\end{array}$ & $\begin{array}{l}<\text { An invalid record type will cause a parsing error } \\
\text { in XML because no Record Element Tag is } \\
\text { defined (see Table 97).> }\end{array}$ & & & & & $x$ \\
\hline
\end{tabular}

Table C.8 - Assertions for Record Type 6 - Deprecated

\begin{tabular}{|c|c|c|c|c|c|c|c|c|c|c|c|}
\hline $\begin{array}{l}\text { Requireme } \\
\text { nt } \\
\text { ID }\end{array}$ & $\begin{array}{c}\text { Referen } \\
\text { ce in } \\
\text { Base } \\
\text { Standar } \\
\text { d }\end{array}$ & $\begin{array}{l}\text { Requirement } \\
\text { Summary }\end{array}$ & $\begin{array}{l}\text { L } \\
\text { e } \\
\text { v } \\
\text { e } \\
\text { I }\end{array}$ & $\begin{array}{l}\mathrm{S} \\
\mathrm{t} \\
\mathrm{a} \\
\mathrm{t} \\
\mathrm{u} \\
\mathrm{s}\end{array}$ & $\begin{array}{l}\text { Assertion } \\
\text { ID }\end{array}$ & $\begin{array}{l}\text { Test } \\
\text { Assertion }\end{array}$ & $\begin{array}{l}\text { Test } \\
\text { Note }\end{array}$ & $\begin{array}{l}\text { Implemen } \\
\text { tation } \\
\text { Support }\end{array}$ & $\begin{array}{l}\text { Supporte } \\
\text { d Range }\end{array}$ & $\begin{array}{c}\text { Test } \\
\text { Result }\end{array}$ & $\begin{array}{c}\text { Applicab } \\
\text { ility }\end{array}$ \\
\hline \multicolumn{12}{|c|}{ 8.6: Record Type-6: DEPRECATED } \\
\hline \multirow[t]{2}{*}{$\begin{array}{l}\text { Transaction: } \\
\text { Type6 Zero } \\
\text { Occurrences }\end{array}$} & \multirow[t]{2}{*}{8.6} & \multirow[t]{2}{*}{$\begin{array}{l}\text { No instances of Record Type- } 6 \text { shall be } \\
\text { included in a transaction conformant with } \\
\text { this version of the standard. }\end{array}$} & 2 & $M$ & $\begin{array}{l}\text { Type6-Zero } \\
\text { Occurrence } \\
\text { s }\end{array}$ & $\begin{array}{l}\text { ForEach(Record in Transaction) } \\
\{ \\
\text { Type(Record) NEQ } 6 \\
\}\end{array}$ & & & & & $\mathrm{T}$ \\
\hline & & & 2 & $M$ & $\begin{array}{l}\text { NIEM- } \\
\text { Type6-Zero } \\
\text { Occurrence } \\
\text { s }\end{array}$ & $\begin{array}{l}<\text { An invalid record type will cause a parsing error } \\
\text { in XML because no Record Element Tag is } \\
\text { defined (see Table 97).> }\end{array}$ & & & & & $x$ \\
\hline
\end{tabular}


Table C.9 - Assertions for Record Type 10 - Facial, Other Body Parts \& SMT Image Record

\begin{tabular}{|c|c|c|c|c|c|c|c|c|c|c|c|}
\hline $\begin{array}{l}\text { Requireme } \\
\text { nt } \\
\text { ID }\end{array}$ & $\begin{array}{l}\text { Referen } \\
\text { ce in } \\
\text { Base } \\
\text { Standar } \\
\quad \text { d }\end{array}$ & $\begin{array}{l}\text { Requirement } \\
\text { Summary }\end{array}$ & $\begin{array}{l}\text { L } \\
\text { e } \\
\text { v } \\
\text { e } \\
\text { I }\end{array}$ & \begin{tabular}{l|l}
$\mathrm{s}$ & \\
$\mathrm{t}$ & \\
$\mathrm{a}$ & $\mathrm{u}$ \\
$\mathrm{t}$ & $\mathrm{s}$
\end{tabular} & $\begin{array}{l}\text { Assertion } \\
\text { ID }\end{array}$ & $\begin{array}{l}\text { Test } \\
\text { Assertion }\end{array}$ & $\begin{array}{l}\text { Test } \\
\text { Note }\end{array}$ & $\begin{array}{l}\text { Implemen } \\
\text { tation } \\
\text { Support }\end{array}$ & $\begin{array}{l}\text { Supporte } \\
\text { d Range }\end{array}$ & $\begin{array}{l}\text { Test } \\
\text { Result }\end{array}$ & $\begin{array}{l}\text { Applicab } \\
\text { ility }\end{array}$ \\
\hline \multicolumn{12}{|c|}{ 8.10: Record Type-10: Facial, other body part and SMT image record } \\
\hline \multirow{11}{*}{$\begin{array}{l}\text { Field: } \\
\text { Type10- } \\
\text { Subfield } \\
\text { Occurrence }\end{array}$} & \multirow[t]{11}{*}{ Table 53} & \multirow[t]{11}{*}{$\begin{array}{l}<\text { Table } 53 \text { specifies which fields contain } \\
\text { subfields as well as the number of } \\
\text { occurrences permitted.> }\end{array}$} & 1 & M & $\begin{array}{l}\text { Type10- } \\
\text { Subfields } \\
\text { Zero }\end{array}$ & $\begin{array}{l}\text { Count(Subfields in 10.[001 to } 003,005 \text { to } 013 \text {, } \\
016,017,020,021,027,030,031,038,039,903 \text {, } \\
996,999]) \text { EQ } 0\end{array}$ & & & & & $\mathrm{~T}$ \\
\hline & & & 1 & M & $\begin{array}{l}10.004- \\
\text { Subfields }\end{array}$ & Count(US_Subfields in 10.004) EQ 1 OR 2 & & & & & $\mathrm{~T}$ \\
\hline & & & 1 & $\mathrm{D}$ & $\begin{array}{l}\text { 10.014- } \\
\text { Subfields }\end{array}$ & Count(US_Subfields in 10.014 ) EQ 4 OR 5 & & & & & $\mathrm{~T}$ \\
\hline & & & 1 & $\mathrm{D}$ & $\begin{array}{l}10.018- \\
\text { Subfields }\end{array}$ & Count(US_Subfields in 10.018 ) EQ 3 & & & & & $\mathrm{~T}$ \\
\hline & & & 1 & $\mathrm{D}$ & $\begin{array}{l}\text { 10.019- } \\
\text { Subfields }\end{array}$ & Count(US_Subfields in 10.019 ) MO [1 to 3] & & & & & $\mathrm{T}$ \\
\hline & & & 1 & $\mathrm{D}$ & $\begin{array}{l}10.023- \\
\text { Subfields }\end{array}$ & $\begin{array}{l}\text { IF \{US_Subfield:1 in 10.023\} EQ ASCII(VENDOR) } \\
\text { THEN } \\
\text { Count(US_Subfields in 10.023) EQ } 1 \text { OR } 2 \\
\text { ELSE } \\
\text { Count(US_Subfields in 10.023) EQ } 1\end{array}$ & & & & & $\mathrm{~T}$ \\
\hline & & & 1 & $\mathrm{D}$ & $\begin{array}{l}10.024- \\
\text { Subfields }\end{array}$ & $\begin{array}{l}\text { Count(RS_Subfields in } 10.024 \text { ) MO [1 to 9] } \\
\text { AND } \\
\text { ForEach(RS_Subfield in 10.024) } \\
\left\{\begin{array}{l}\text { Count(US_Subfields in RS_Subfield) EQ } 3 \\
\}\end{array}\right.\end{array}$ & & & & & $\mathrm{T}$ \\
\hline & & & 1 & $\mathrm{D}$ & $\begin{array}{l}10.025- \\
\text { Subfields }\end{array}$ & Count(US_Subfields in 10.025 ) MO [3 to 6] & & & & & $\mathrm{T}$ \\
\hline & & & 1 & $\mathrm{D}$ & $\begin{array}{l}10.026- \\
\text { Subfields }\end{array}$ & Count(US_Subfields in 10.026) MO [1 to 50] & & & & & $\mathrm{T}$ \\
\hline & & & 1 & $\mathrm{D}$ & $\begin{array}{l}10.028- \\
\text { Subfields }\end{array}$ & Count(US_Subfields in 10.028 ) EQ 1 OR 2 & & & & & $\mathrm{~T}$ \\
\hline & & & 1 & $\mathrm{D}$ & $\begin{array}{l}10.029- \\
\text { Subfields }\end{array}$ & $\begin{array}{l}\text { Count(RS_Subfields in } 10.029) \text { MO [1 to 88] } \\
\text { AND }\end{array}$ & & & & & $\mathrm{T}$ \\
\hline
\end{tabular}




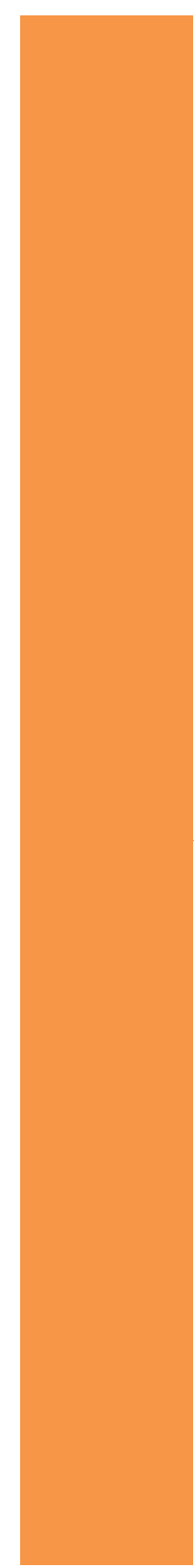

ForEach(RS_Subfield in 10.029)

\{

Count(US_Subfields in RS_Subfield) EQ 4

1 D 10.032-

Subfields

Count(RS_Subfields in 10.032 ) MO [1 to 88]

AND

ForEach(RS Subfield in 10.032)

\{

Count(US_Subfields in RS_Subfield) EQ 5

1 D 10.033-

Subfields

Count(RS_Subfields in 10.033) MO [1 to 12]

AND

ForEach(RS Subfield in 10.033)

Count(US_Subfields in RS_Subfield) EQ 2 +

$2 *\{$ US_Subfield:2 in RS_Subfield $\}$

\}

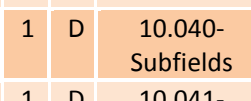

Count(US_Subfields in 10.040) MO [1 to 3]

1 D 10.041-

Count(US_Subfields in 10.041) EQ 2

2 D 10.042 Subfields

\section{AND}

ForEach(RS_Subfield in 10.042)

\{

Present(US_Subfield:2,3 in RS_Subfield)

\{US Subfield: 1 in RS Subfield\} MO

[ASCII(TATTOO, CHEMICAL, BRANDED, CUT)]

THEN

AND

IF \{US_Subfield: 1 in RS_Subfield $\}$ MO

[ASCII(TATTOO, CHEMICAL, BRANDED, CUT)]

THEN

Count(US_Subfields in RS_Subfield) MO [3,4]

ELSE

Count(US_Subfields in RS_Subfield) EQ 1 


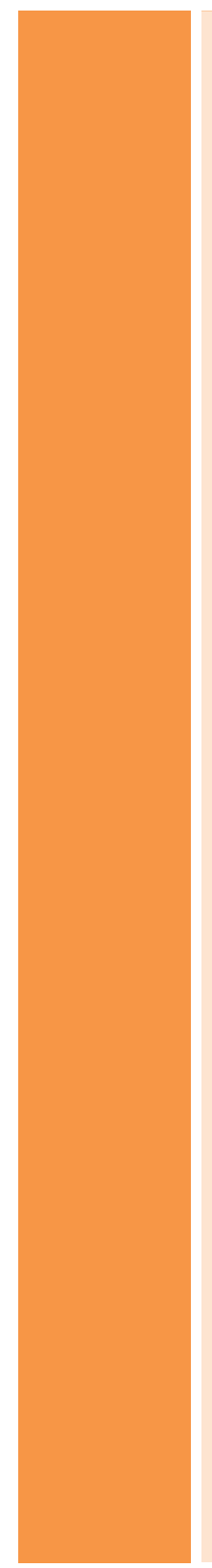

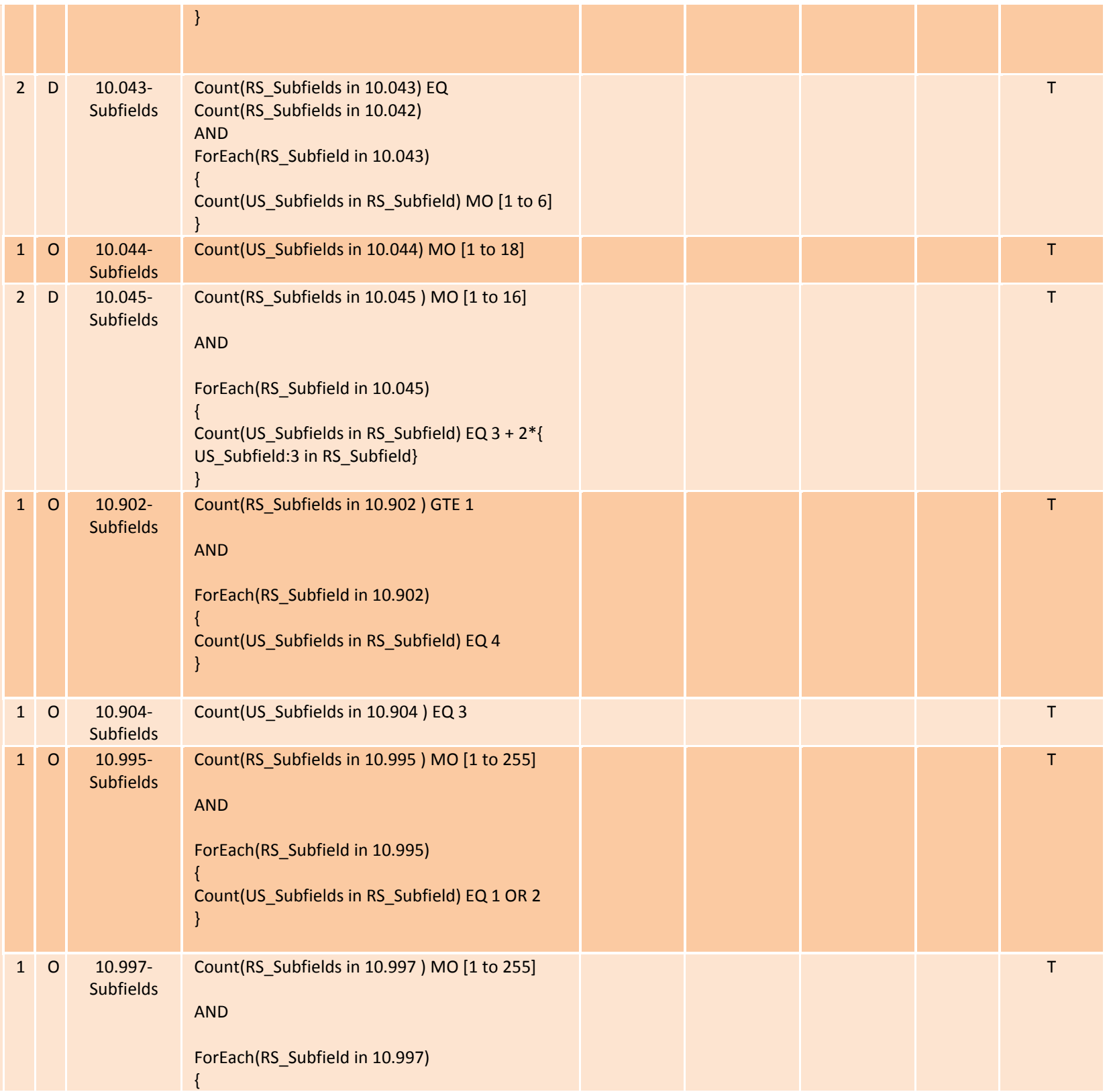




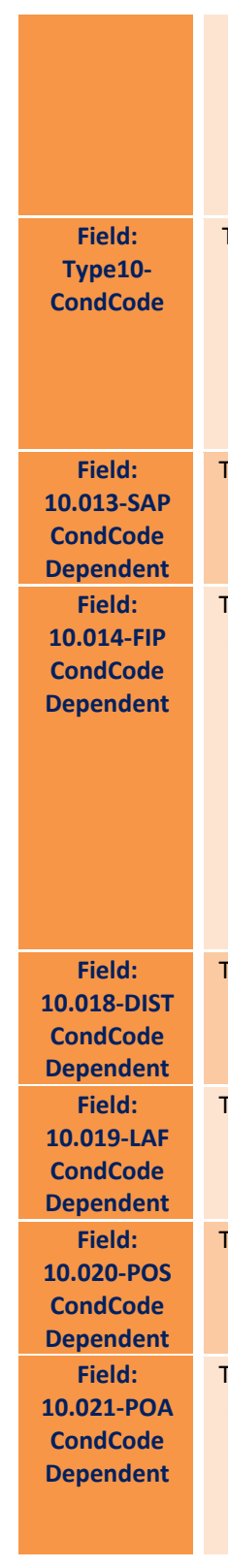

Table 53

$<$ Table 53 specifies the Condition Code for each field.>

Count(US_Subfields in RS_Subfield) EQ 1 OR 2

\}

0 10.998- <See Requirement ID: "Field: Geographic-

Subfields Conditional">

1 M Type10CondCode

Present(10.001 to $10.012,10.999)$

AND

NOT Present(10.015,10.022, 10.034 to

$10.037,10.046$ to $10.199,10.901,10.905$ to

10.994)

Table 53, The Subject Acquisition Profile (SAP) is
8.10 .13
mandatory field when Field 10.003: Im

mandatory field when Field 10.003: Image type / IMT contains "FACE". Otherwise, it shall not be entered.

Table 53, If the face image (IMT = 'FACE') contains

8.10.14 more than one face, or is not cropped to a

"head only" or "head and shoulders"

composition, this optional field contains

offsets to the location of the bounding

box of the face of the subject within a

larger image. This field is only appropriate

for images that do not comply with SAP

Levels $30,40,50$ or 51 , because those

images shall be cropped to a "head only"

or "head and shoulders" composition.

Table 53, This optional field (which can be used

only if IMT is 'FACE')...

This optional field ...is only applicable to

$10.013-$

<See Requirement ID: “Field: SAP Conditional”

CondCode

Dependent

2 D 10.014

CondCode

Dependent

IF Present(10.014) THEN

$\{10.003\}$ EQ ASCII(FACE)

AND

10.018CondCode

Dependent

8.10.18 face images (IMT = 'FACE').

10.019-

CondCode

Dependent

Table 53, This optional field is to be used for the

2 D

10.020-

CondCode

Dependent

Table 53,
8.10 .20

This shall only be used for the exchange

of facial image data (IMT = 'FACE'). It may

be used if Field 10.020: Subject pose /

2 D 10.021-

CondCode

Dependent

POS contains an " $A$ " to indicate an angled pose of the subject. The field shall not be used if the entry in POS is an "F", " $R$ ", " $L$ "

$\{10.013\}$ NOT MO $[30,40,50,51]$

\section{(10)}

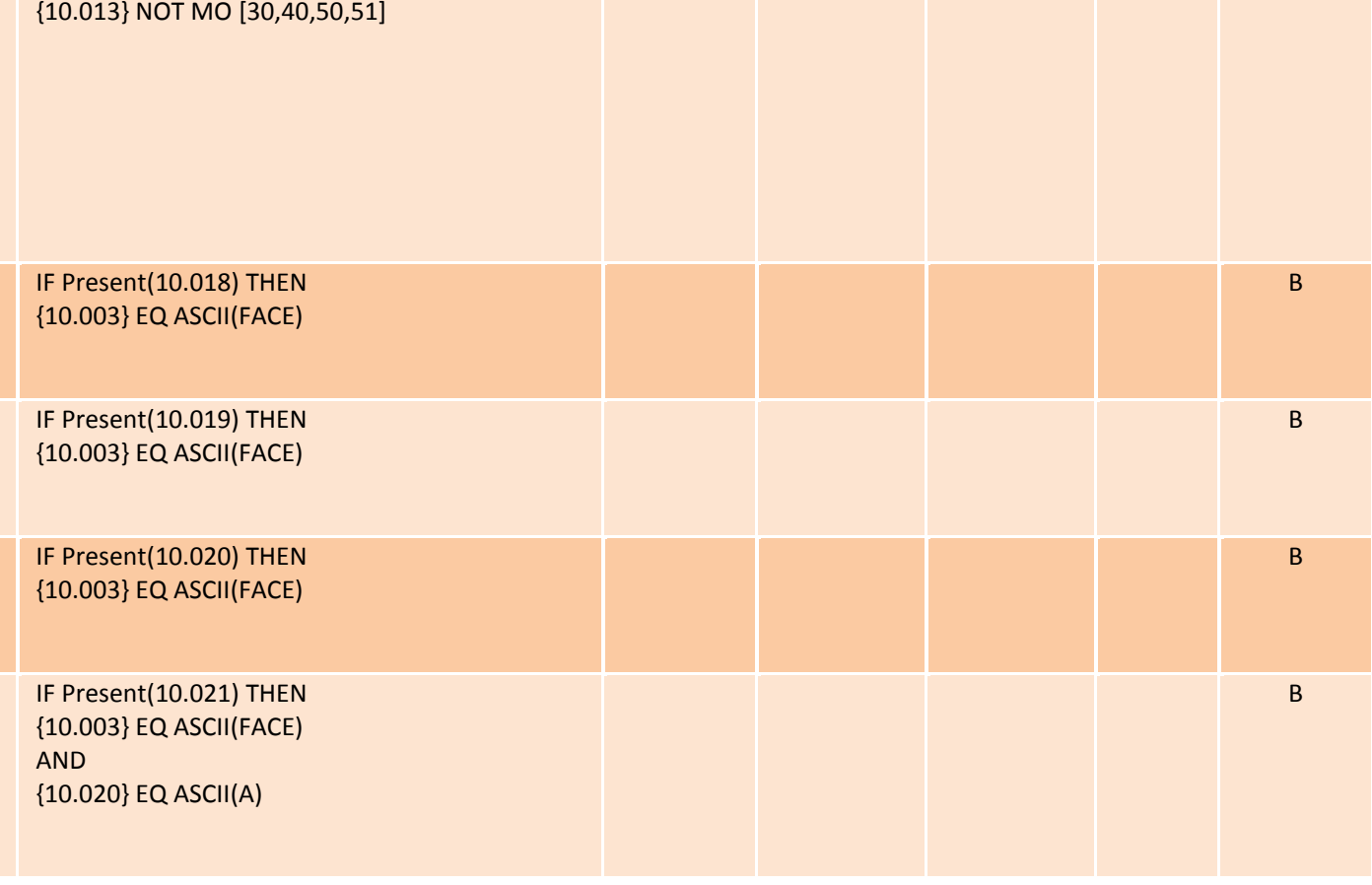


or "D".

\begin{tabular}{|c|}
\hline $\begin{array}{c}\text { Field: } \\
\text { 10.023-PAS } \\
\text { CondCode } \\
\text { Dependent }\end{array}$ \\
\hline $\begin{array}{l}\text { Field: } \\
\text { 10.024-SQS } \\
\text { CondCode } \\
\text { Dependent }\end{array}$ \\
\hline $\begin{array}{c}\text { Field: } \\
\text { 10.025-SPA } \\
\text { CondCode } \\
\text { Dependent }\end{array}$ \\
\hline $\begin{array}{c}\text { Field: } \\
\text { 10.026-SXS } \\
\text { CondCode } \\
\text { Dependent }\end{array}$ \\
\hline $\begin{array}{c}\text { Field: } \\
\text { 10.027-SEC } \\
\text { CondCode } \\
\text { Dependent }\end{array}$ \\
\hline $\begin{array}{c}\text { Field: } \\
\text { 10.028-SHC } \\
\text { CondCode } \\
\text { Dependent }\end{array}$ \\
\hline $\begin{array}{l}\text { Field: } \\
\text { 10.029-FFP } \\
\text { CondCode } \\
\text { Dependent }\end{array}$ \\
\hline $\begin{array}{c}\text { Field: } \\
\text { 10.031-TMC } \\
\text { CondCode } \\
\text { Dependent }\end{array}$ \\
\hline $\begin{array}{l}\text { Field: } \\
\text { 10.032-3DF } \\
\text { CondCode } \\
\text { Dependent }\end{array}$ \\
\hline $\begin{array}{l}\text { Field: } \\
\text { 10.033-FEC } \\
\text { CondCode }\end{array}$ \\
\hline
\end{tabular}

8.10 .27

8.10 .30

8.10 .29 \begin{tabular}{|l|l|l|l|l|}
\hline Table 53, & or “D”. & & \\
\hline
\end{tabular}

10.013: Subject acquisition profile/

SAP) is " 40 " or greater for face image

records. (IMT=FACE only).

Table 53, This optional field shall specify quality

8.10.22 score data for facial images (IMT = 'FACE')

(1)

Table 53, This field shall be present when Field

8.10.23 10.020: Subject pose / POS contains a "D"

to indicate a set of determined 3D pose

angles of the same subject for a facial

image (IMT = 'FACE'). If the entry in POS is

an " $F$ ", " $L$ ", " $R$ " or " $D$ ", this field shall not

be used

Table 53, This field is mandatory if the SAP entry for

8.10.24 a facial image (Field 10.013: Subject

acquisition profile / SAP) is 40,50 or 51 .

(IMT=FACE only). In other cases, this field

is optional for facial images.

Table 53, This field is mandatory if the SAP entry

8.10.25 (Field 10.013: Subject acquisition profile /

SAP) is " 40 " or greater. For other facial

images (IMT = 'FACE'), the field is

optional.

Table 53, This field is mandatory if the SAP entry

8.10.26 (Field 10.013: Subject acquisition profile /

SAP) is " 40 " or greater. For other facial

image $s(I M T=$ 'FACE'), it is optional.

Table 53, The optional field shall be used for the

exchange of facial image data (IMT =

'FACE') feature points or landmarks.

Table 53, This optional field describes the specific

8.10.29 facial (IMT = 'FACE') feature points

Table 53, The optional field shall describe ...facia

feature points of the captured facial

image(IMT = 'FACE').

Table 53, ...refers to a specific contour on the face

8.10.31, $\quad($ IMT = 'FACE')
CondCode

10.024-

CondCode

Dependent

2 D $10.025-$

CondCode
Dependent

D 10.026-

CondCode

Dependent

2 D 10.027-

CondCode

Dependent

2 D 10.028-

CondCode

Dependent

D 10.029-

CondCode

Dependent

2 D 10.031-

CondCode

Dependent

D 10.032-

CondCode

Dependent

2 D $10.033-$

CondCode

Dependent

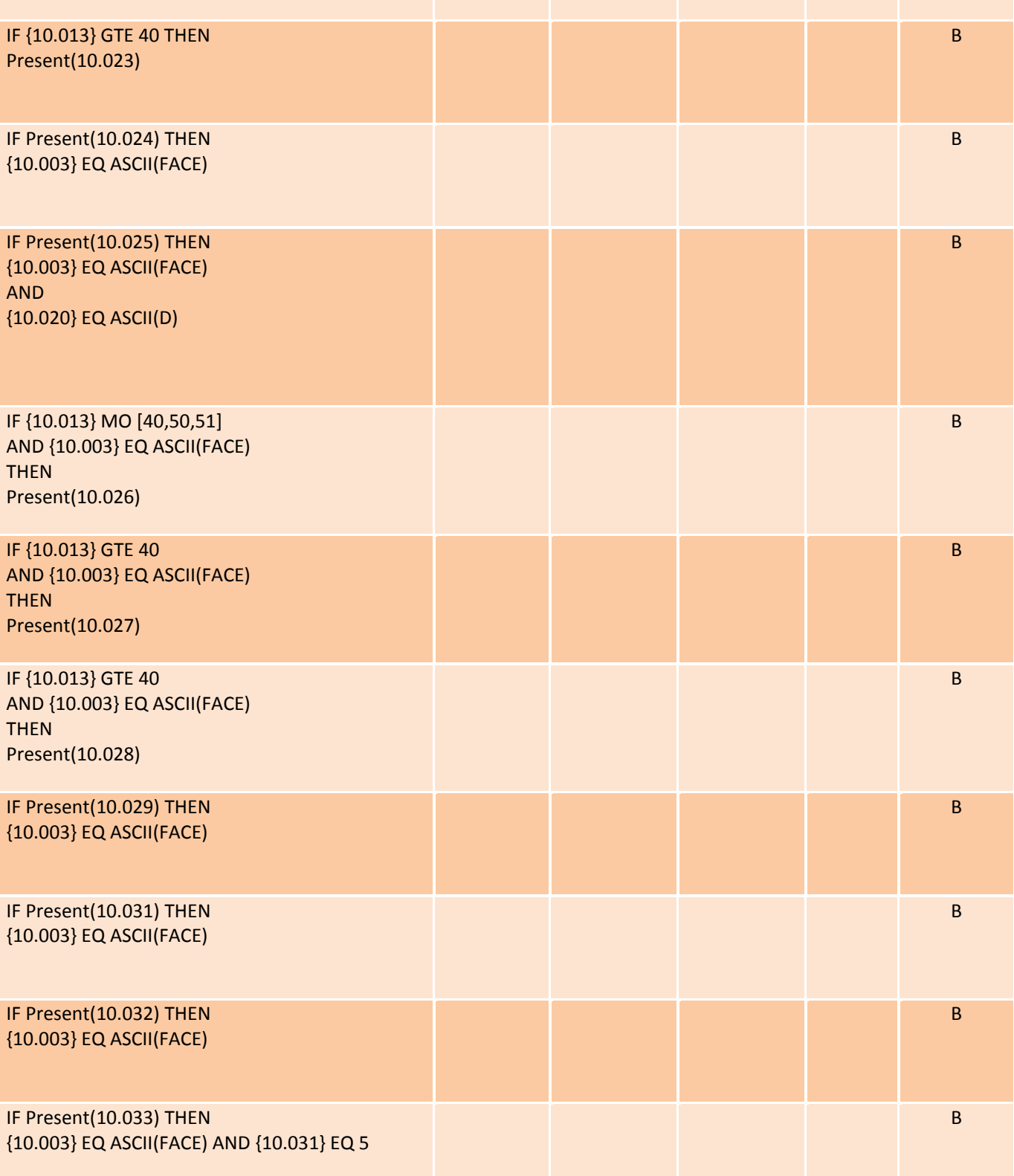




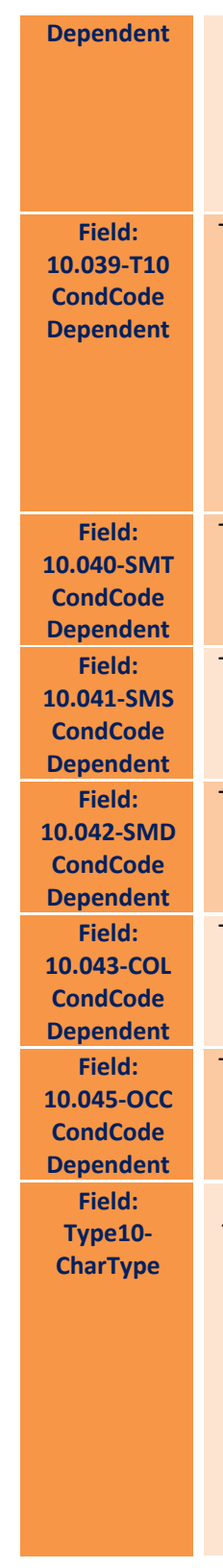

\begin{tabular}{|c|c|}
\hline & $\begin{array}{l}\text { Field 10.031: This optional field describes } \\
\text { the specific facial (IMT= 'FACE') feature } \\
\text { points contained in Field 10.029: } 2 \mathrm{~d} \text { Facial } \\
\text { feature points/ FFP and if level 5, } \\
\text { contours shall be contained in Field } \\
\text { 10.033: Feature contours/ FEC. }\end{array}$ \\
\hline $\begin{array}{l}\text { Table 53, } \\
8.10 .33\end{array}$ & $\begin{array}{l}\text { This field shall } \\
\text { not be used if there are no multiple } \\
\text { images of the same SMT or body part in } \\
\text { the transaction }\end{array}$ \\
\hline $\begin{array}{l}\text { Table 53, } \\
8.10 .34\end{array}$ & $\begin{array}{l}\text { This field shall be used only when Field } \\
\text { 10.003: Image type / IMT = "SCAR", } \\
\text { "MARK", or "TATTOO". It is not used for } \\
\text { other images }\end{array}$ \\
\hline $\begin{array}{l}\text { Table 53, } \\
8.10 .35\end{array}$ & $\begin{array}{l}\text { This field shall be used only when Field } \\
\text { 10.003: Image type / IMT ="SCAR", } \\
\text { "MARK", or "TATTOO". }\end{array}$ \\
\hline $\begin{array}{l}\text { Table 53, } \\
8.10 .36\end{array}$ & $\begin{array}{l}\text { This field shall be used only when Field } \\
\text { 10.003: Image type /IMT = "SCAR", } \\
\text { "MARK", or "TATTOO". }\end{array}$ \\
\hline $\begin{array}{l}\text { Table } 53, \\
8.10 .37\end{array}$ & $\begin{array}{l}\text { This optional field shall contain one } \\
\text { subfield corresponding to each subfield } \\
\text { contained in } \\
\text { Field 10.042: SMT descriptors / SMD }\end{array}$ \\
\hline $\begin{array}{l}\text { Table 53, } \\
8.10 .37\end{array}$ & $\begin{array}{l}\text { This optional field defines ...the image of } \\
\text { the face (IMT = 'FACE'). }\end{array}$ \\
\hline $\begin{array}{l}8.10 \\
\text { Table } 53\end{array}$ & $\begin{array}{l}<\text { Table } 53 \text { specifies the Character Type for } \\
\text { each field that contains no subfields. Note } \\
\text { that even though some Character Types } \\
\text { are listed as } U \text { (user defined), they may } \\
\text { still have character type limitations } \\
\text { defined in the standard text. > }\end{array}$ \\
\hline
\end{tabular}

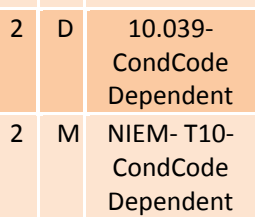

2 D $10.040-$ CondCode Dependent

2 D $10.041-$ CondCode Dependent

2 D $10.042-$ Dependent

2 D 10.043CondCode Dependent

2 D $10.045-$ CondCode Dependent

1 - Type10CharType $\mathrm{N}$

1 - Type10-

CharType A

Type10CharType

1 M 10.003CharTyp AS

1 D 10.021
IF Present(10.039) THEN

Count(Records ST Type(Record) EQ 10) GTE 2

Present(XEIm(biom:PhysicalFeatureReferencelde ntification)

THEN

Count(XEIm(itl:PackageFacialAndSMTImageReco

rd)) GTE 2

IF Present(10.040) THEN

\{1.003\} MO [ASCII(SCAR,MARK,TATTOO)]

IF Present(10.041) THEN

1.003\} MO [ASCII(SCAR,MARK,TATTOO)]

IF Present(10.042) THEN

$\{1.003\} \mathrm{MO}$ [ASCII(SCAR,MARK,TATTOO)]

IF Present(10.043) THEN

Present(10.042)

IF Present(10.045) THEN

$\{10.003\}$ EQ ASCII(FACE)

Bytes(10.[001,002,005 to 010

\begin{tabular}{|l|l|l|}
\hline 7 & B \\
\hline
\end{tabular}

$\operatorname{Bytes}(10 .[011,012,020,027,030]) \mathrm{MO}[0 \times 41$ to

$\{10.026\} \mathrm{MO}[0 \times 41$ to $0 \times 5 \mathrm{~A}, 0 \times 61$ to $0 \times 7 \mathrm{~A}]$

Bytes(10.003) MO [0x2D, 0x41 to 0x5A, 0x61 to 0x7A]

Bytes(10.021) MO [0x2B,0x2D,0x30 to 0x39] 

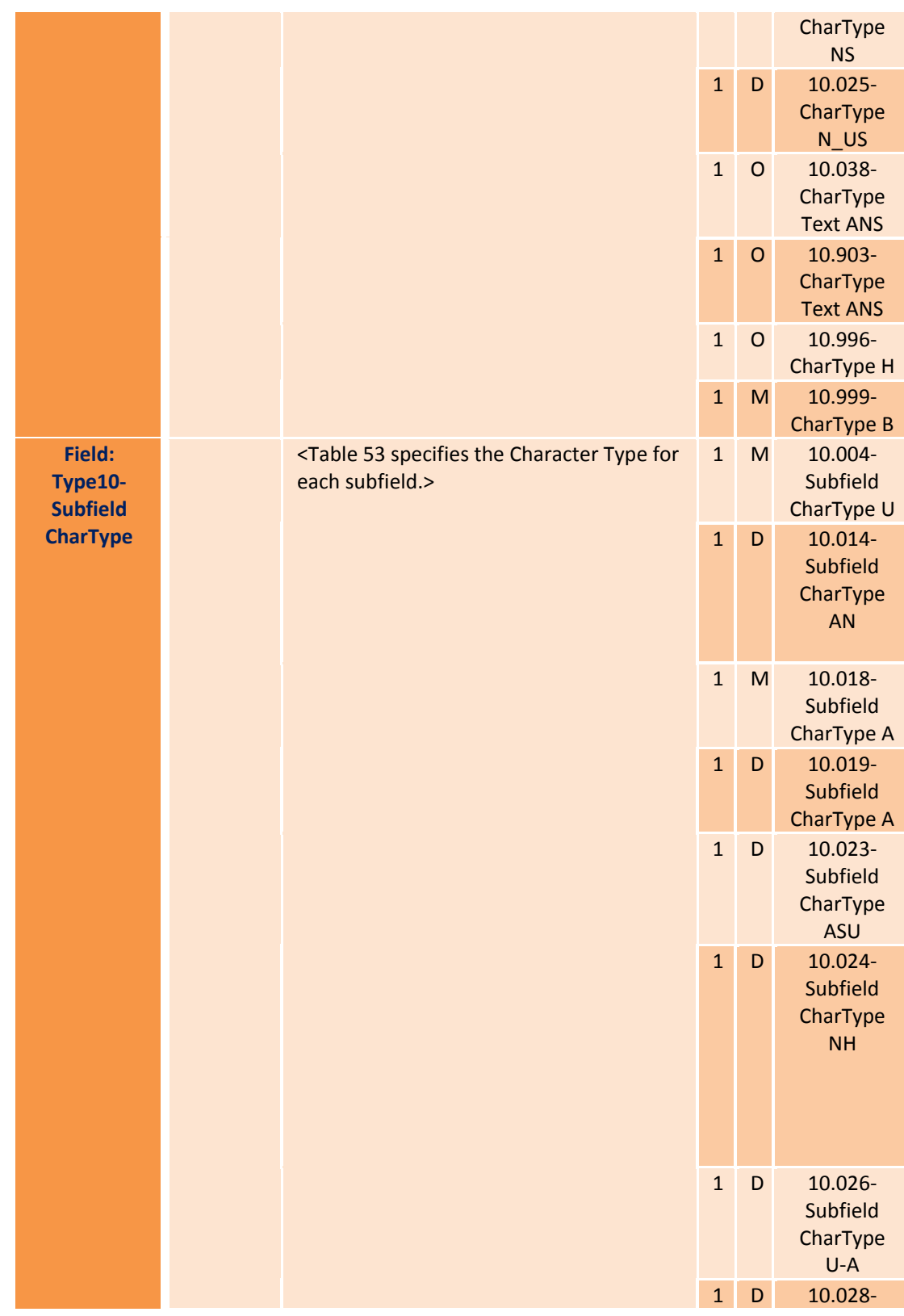

10 10.996-

CharType H

1 M $\begin{gathered}\text { 10.999- } \\ \text { CharType B }\end{gathered}$

1 M 10.004-

Subfield

CharType U

1 D 10.014- Bytes(US_Subfields:1 to 4 in 10.014) MO [0x30 to

Subfield 0x39]

CharType AN

1 M 10.018-

Subfield

CharType A

1 D $10.019-$

CharType A

1 D 10.023

Subfield

CharType

ASU

\begin{tabular}{l|l|l|}
1 & D & $10.024-$ \\
Subfield
\end{tabular}

CharType

$\mathrm{NH}$

Bytes(10.996) MO [0x30 to $0 \times 39,0 \times 41$ to $0 \times 46$,

(10.025) MO [0x1F, 0x2B, 0x2D, 0x30 to

Bytes(10.038) MO [0x20, 0x7E]

Bytes(10.903) MO [0x20, 0x7E]

Ox61 to 0x66]

Present(Bytes(10.999))

Present(Bytes(US_Subfields:1,2 in 10.004)

Bytes(US_Subfields:5 in 10.014) MO [0x41 to

0x5A, 0x61 to 0x7A]

Bytes (All(US Subfields in 10.018)) MO [0x41 to

$0 \times 5 \mathrm{~A}, 0 \times 61$ to $0 \times 7 \mathrm{~A}]$

Bytes(All(US_Subfields in 10.019)) $\mathrm{MO}$ [0x41 to

0x5A, 0x61 to 0x7A]

Bytes(US_Subfields: 1 in 10.023) MO [0×30, 0x32,

$0 \times 41$ to $0 \times 5 \mathrm{~A}, 0 \times 61$ to $0 \times 7 \mathrm{~A}$ ]

Present(Bytes(US_Subfields: 2 in 10.023))

ForEach(RS_Subfield in 10.024)

\{

(US_Subfields:1,3 in RS_Subfield) MO [0×30

to $0 \times 39$ ]

AND

Bytes(US_Subfields: 2 in RS_Subfield) MO [0×30 to $0 \times 39,0 \times 41$ to $0 \times 46,0 \times 61$ to $0 \times 66$ ]

\}

1 D 10.026- Bytes(All(US_Subfields in 10.018)) MO [0x41 to $0 \times 5 \mathrm{~A}, 0 \times 61$ to $0 \times 7 \mathrm{~A}]$

CharTyp

U-A

1 D 10.028- $\quad$ Bytes(All(US_Subfields in 10.028)) MO [0x41 to

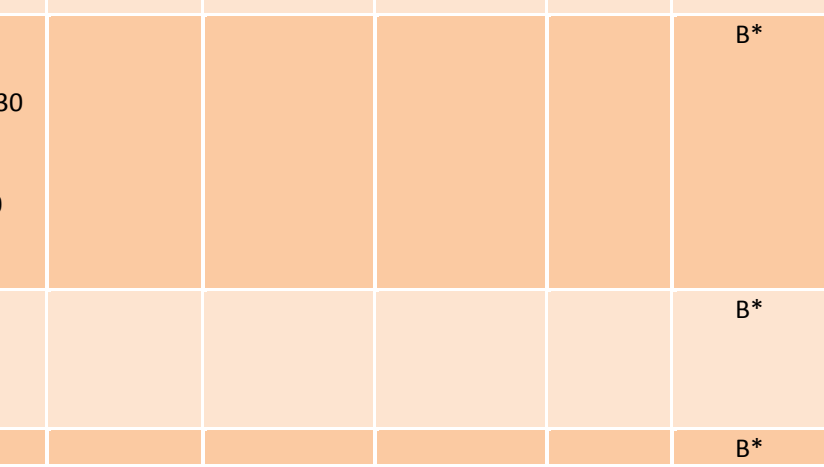



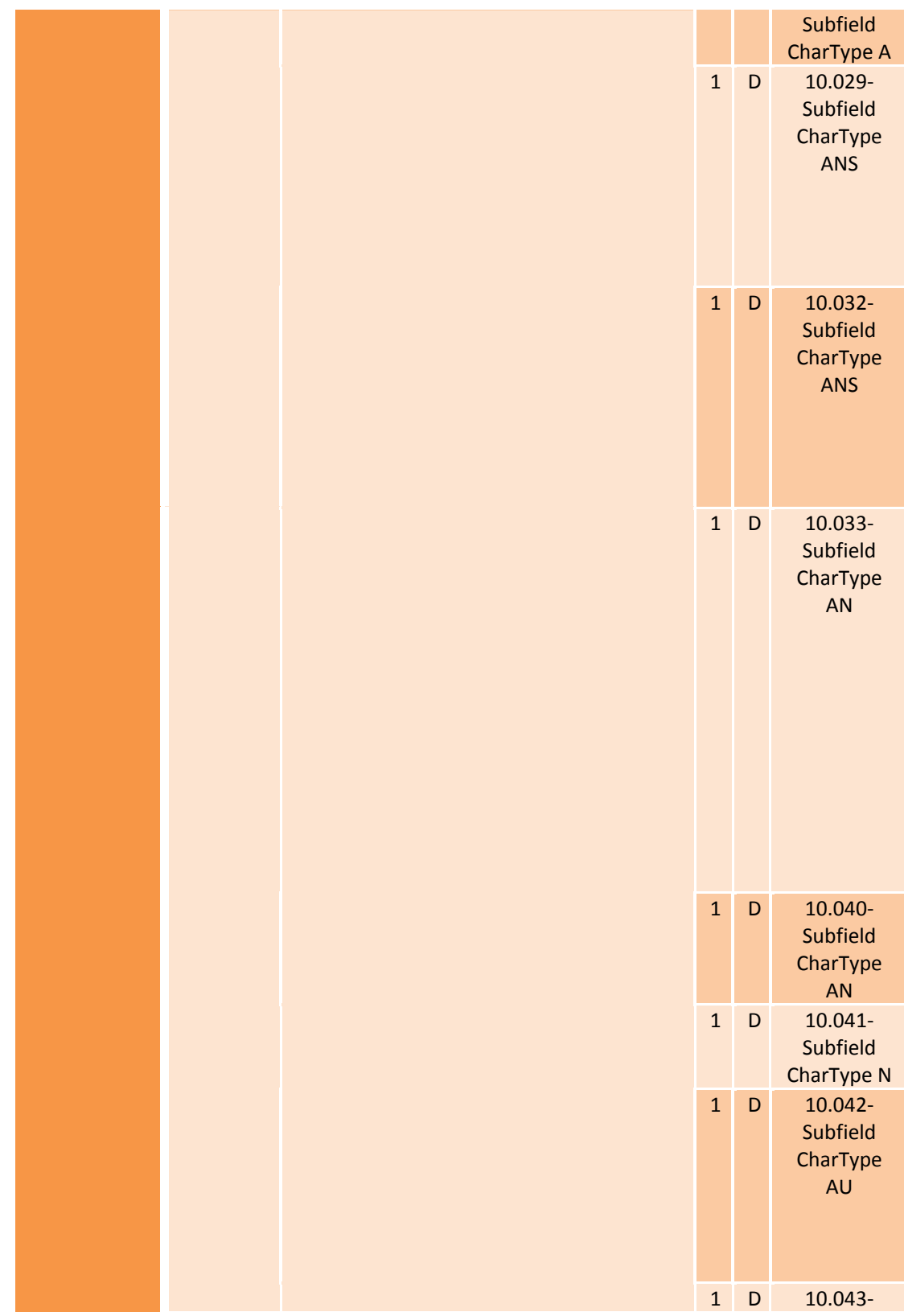

0x5A, $0 \times 61$ to $0 \times 7 \mathrm{~A}]$

ForEach(RS_Subfield in 10.029)

\{

Bytes(US_Subfields:1,3,4 in RS_Subfield) MO

[0x30 to $0 \times 39$ ]

AND

Bytes(US_Subfields: 2 in RS_Subfield) MO [0x2E,

$0 \times 30$ to $0 \times 39,0 \times 41$ to $0 \times 46,0 \times 61$ to $0 \times 66$ ]

ForEach(RS_Subfield in 10.032)

Bytes(US_Subfields:1,3,4 in RS_Subfield) MO

[0x30 to $0 \times 39$ ]

AND

Bytes(US_Subfields: 2 in RS_Subfield) MO [0x2E, $0 \times 30$ to $0 \times 39,0 \times 41$ to $0 \times 46,0 \times 61$ to $0 \times 66$ ]

ForEach(RS Subfield in 10.033)

\{

Bytes(US_Subfield:1 in RS_Subfield) MO [0x41 to

Ox5A, $0 \times 61$ to $0 \times 7 \mathrm{~A}]$

AND

Bytes(US_Subfield:2 in RS_Subfield) MO [0×30 to

0x39]

AND

ForEach(<additional US_Subfield in

RS_Subfield $>$ )

\{

Bytes(US_Subfield) MO [0×30 to 0x39] \}

Bytes(All(US_Subfields in 10.040)) MO [0x30 to $0 \times 39,0 \times 41$ to $0 \times 5 \mathrm{~A}, 0 \times 61$ to $0 \times 7 \mathrm{~A}$ ]

Bytes(All(US Subfields in 10.041)) $\mathrm{MO}$ [0x30 to 0x39]

ForEach(RS_Subfield in 10.042)

Bytes(US_Subfields: 1 to 3 in RS_Subfield) MO [0x41 to $0 \times 46,0 \times 61$ to $0 \times 66$ ]

AND

Present(Bytes(US_Subfields:4 in RS_Subfield) )

Bytes(All(US_Subfields in 10.043)) MO [0x41 to 

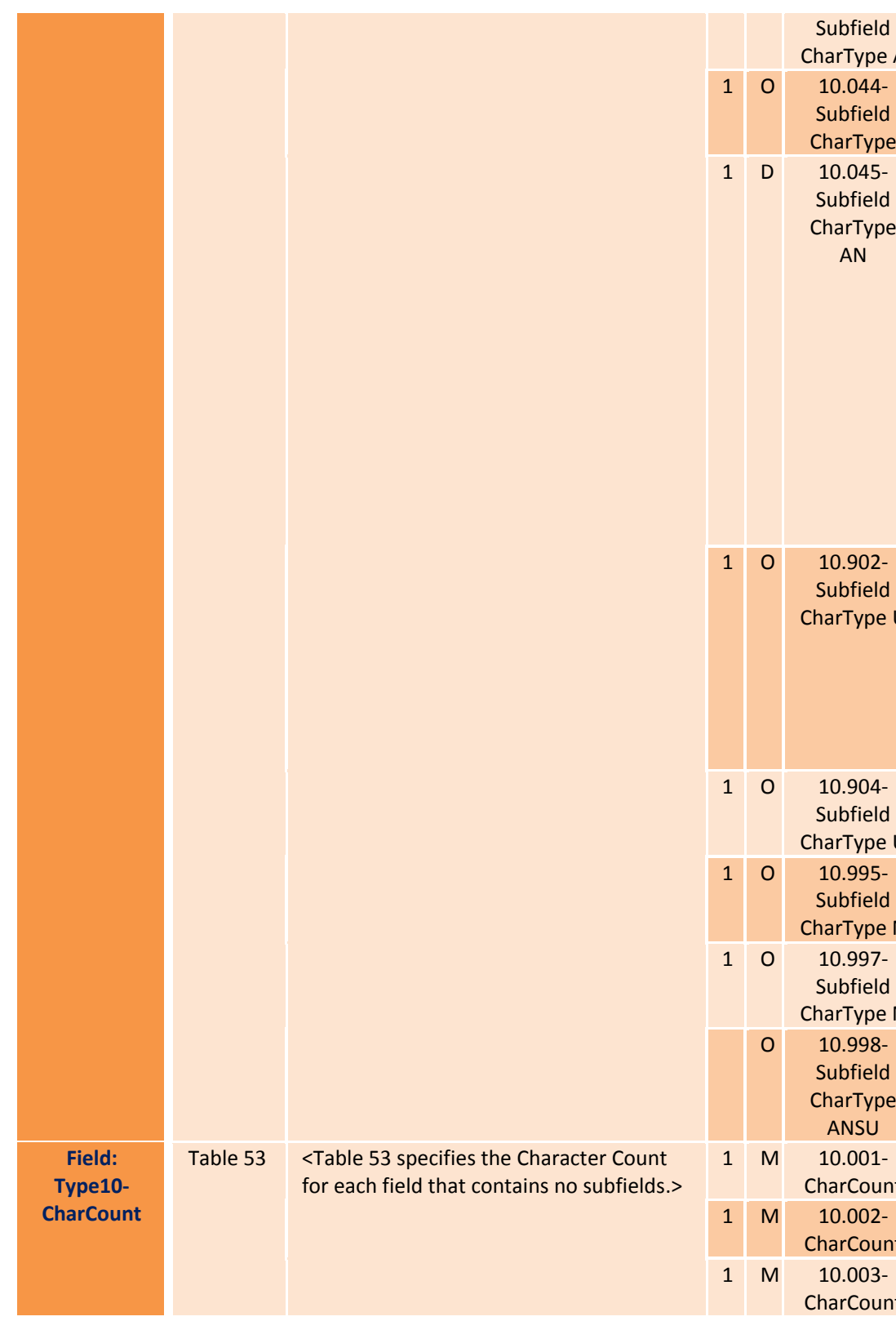

Bytes(All(US_Subfields in 10.044)) MO [0x41 to

$0 \times 46,0 \times 61$ to $0 \times 66$ ]

ForEach(RS_Subfield in 10.045)

\{

Bytes(US_Subfields:1,2 in RS_Subfield) MO [0x41

to $0 \times 5 \mathrm{~A}, 0 \times 61$ to $0 \times 7 \mathrm{~A}$ ]

AND

Bytes(US_Subfield:3 in RS_Subfield)) MO [0×30

to $0 \times 39$ ]

AND

ForEach(<additional US_Subfield in

RS_Subfield $>$ )

\{

Bytes(US_Subfield) MO [0×30 to 0x39]

\}

\begin{tabular}{|l|l|c|}
1 & 0 & $\begin{array}{c}10.902- \\
\text { Subfield } \\
\text { CharType U }\end{array}$
\end{tabular}

ForEach(RS_Subfield in 10.902)

\{

CharType U Present(Bytes(US_Subfields:2 to 4 in

RS_Subfield))

AND

Bytes(US_Subfield:1 in RS_Subfield) MO [0×30 to $0 \times 39,0 \times 5 \mathrm{~A}]$

$10 \quad 10.904-$

Subfield

Present(Bytes(All(US Subfields in 10.904)))

CharType U

10 10.995- Bytes(All(US_Subfields in 10.995)) MO [0x30 to Subfield 0x39]

CharType $N$

10.997

$$
\text { Byt }
$$

Bytes(All(US_Subfields in 10.997)) MO [0×30 to

0x39]

CharType N

O $10.998-$

Subfield

CharType

1 M $\begin{gathered}10.001- \\ \text { CharCount }\end{gathered}$

<See Requirement ID: "Field: Geographic">

DataLength(10.001) GTE 1

1 M 10.002-

CharCount

1 M $\begin{gathered}\text { 10.003- } \\ \text { CharCount }\end{gathered}$

DataLength(10.002) EQ 1 OR 2

DataLength(10.003) MO [1 to 11$]$ 


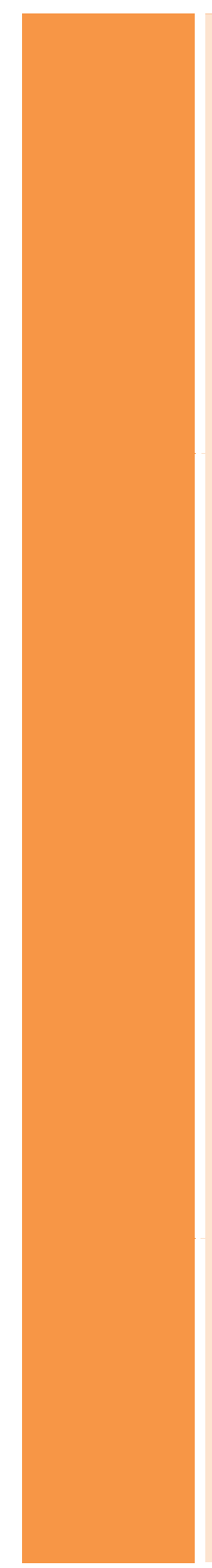

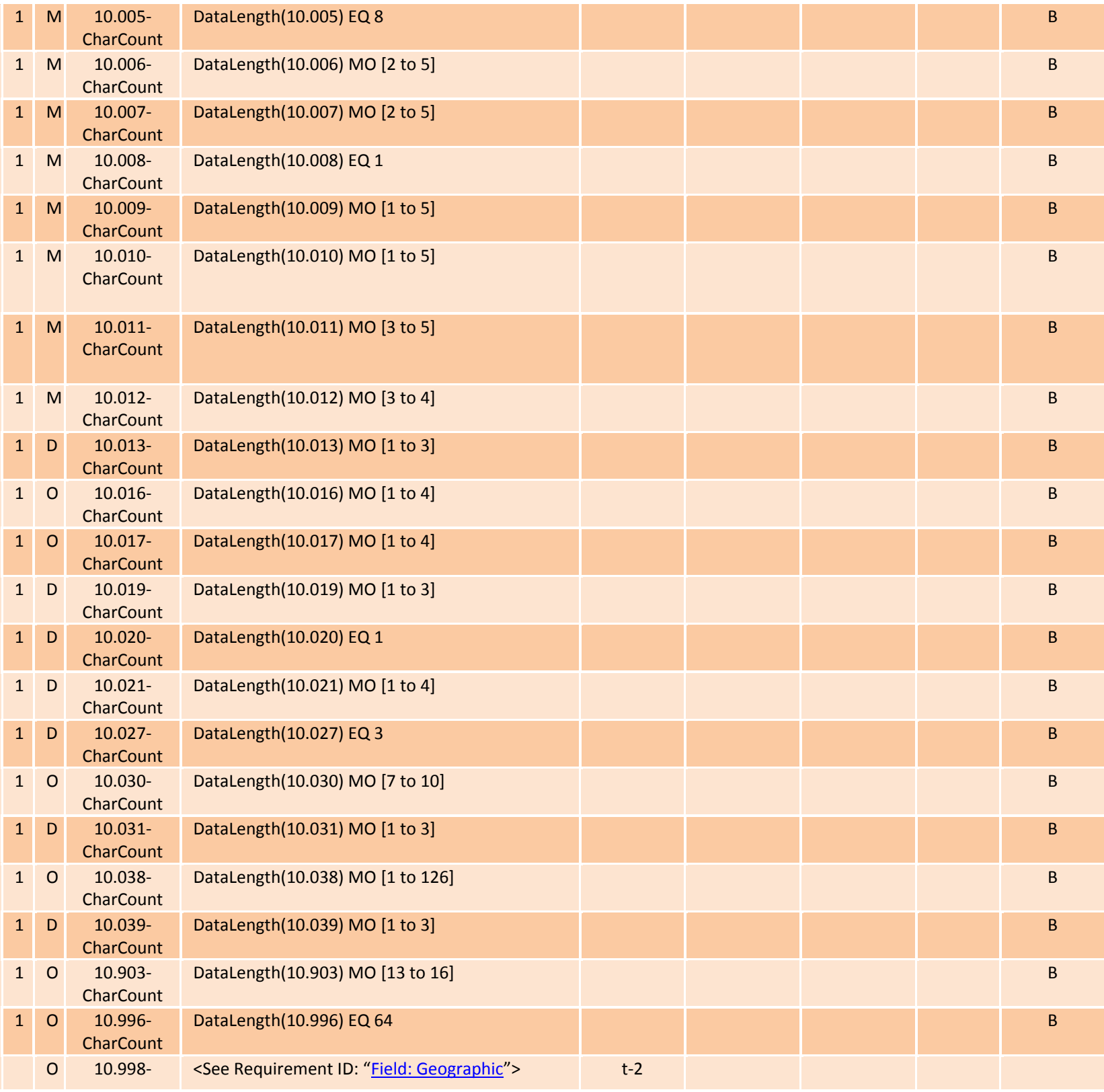




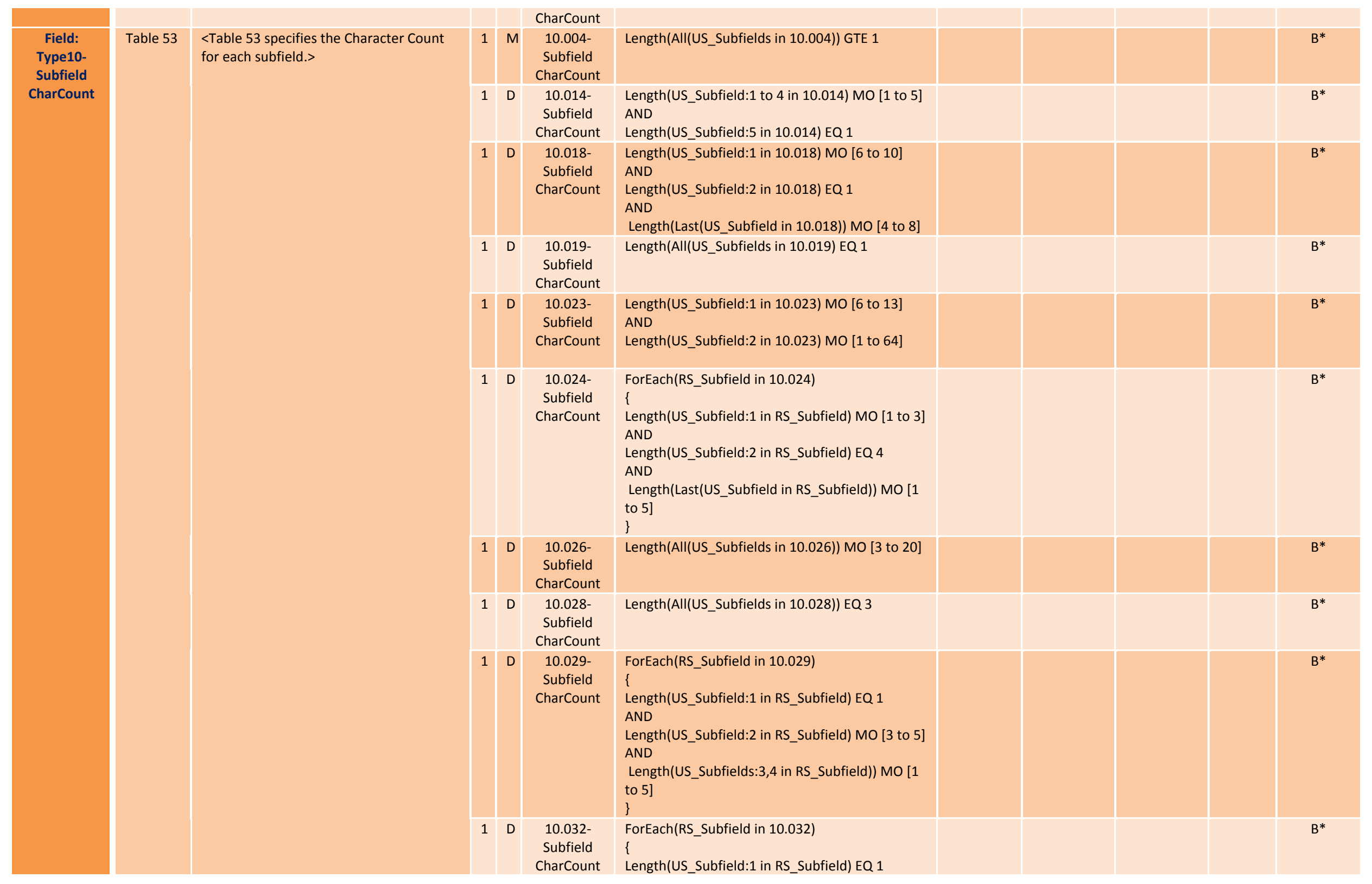




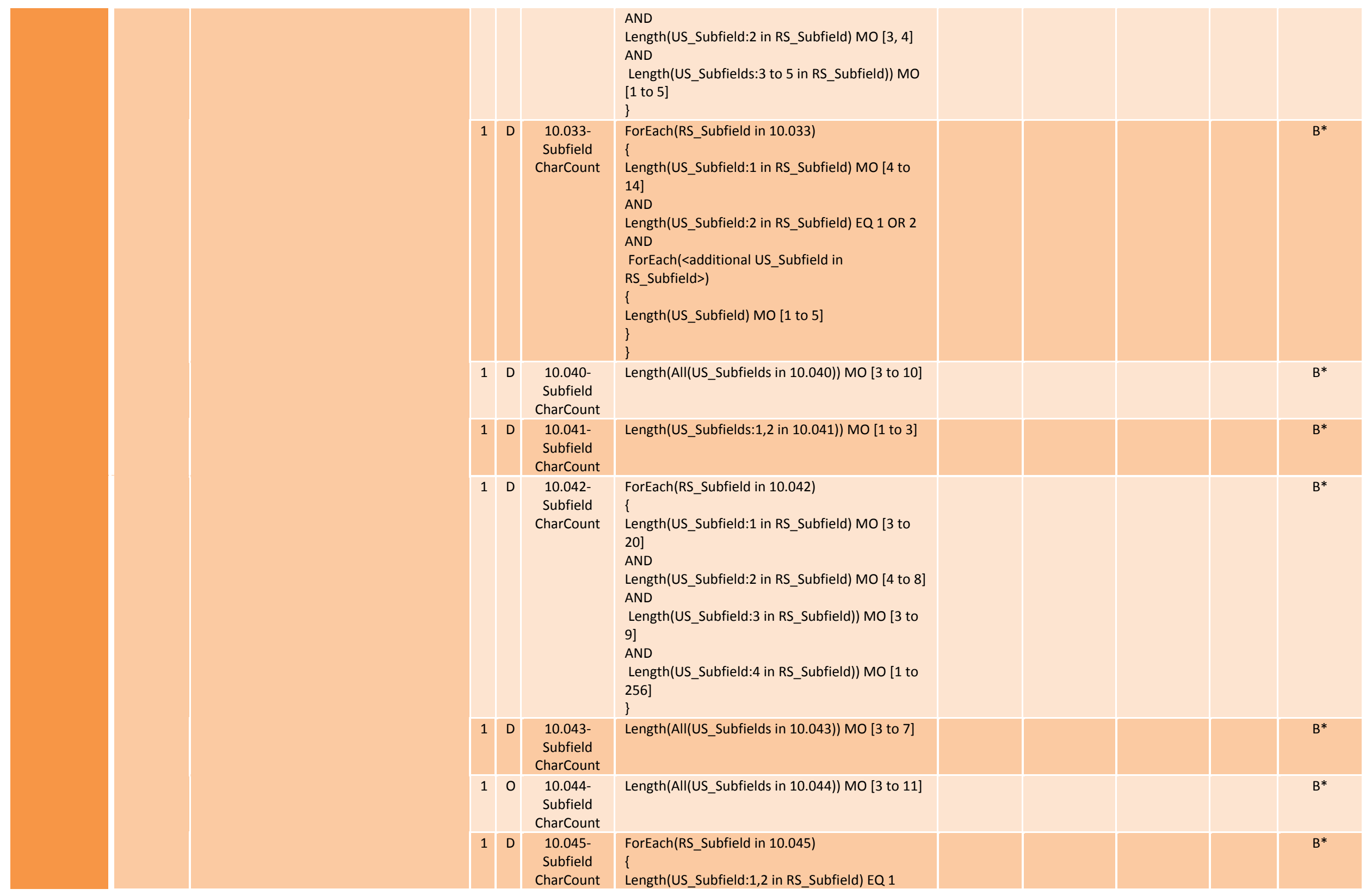




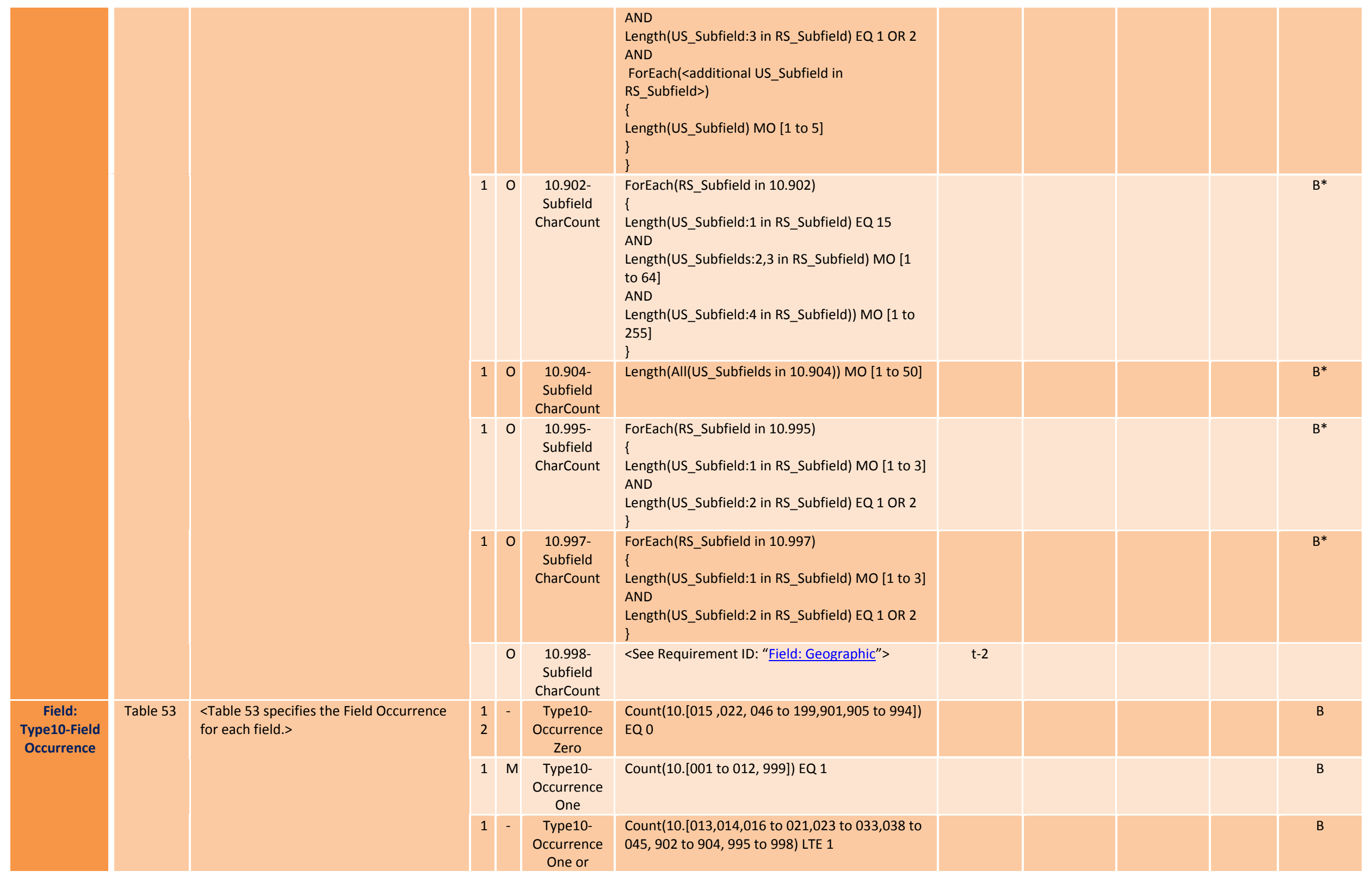




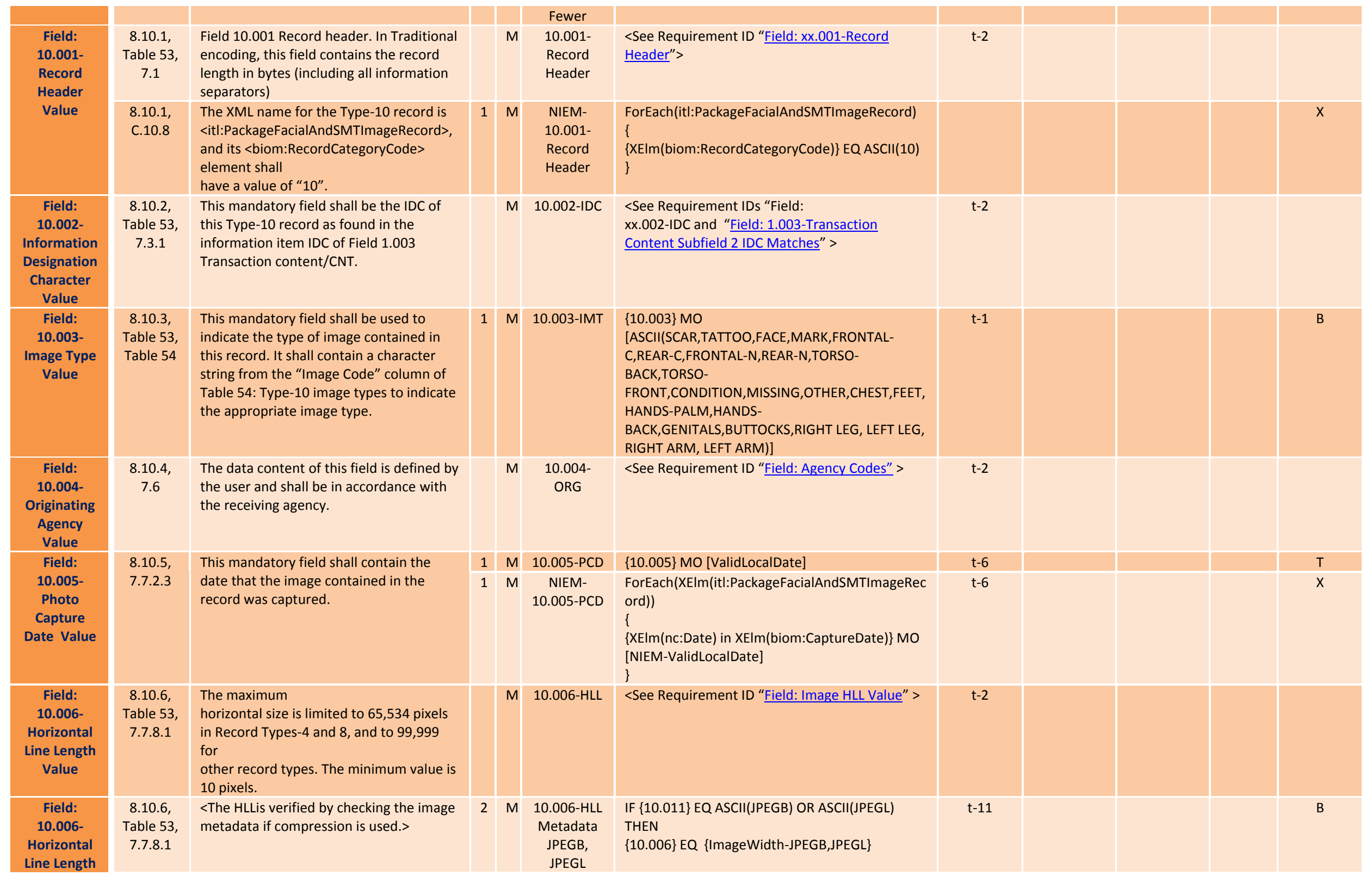




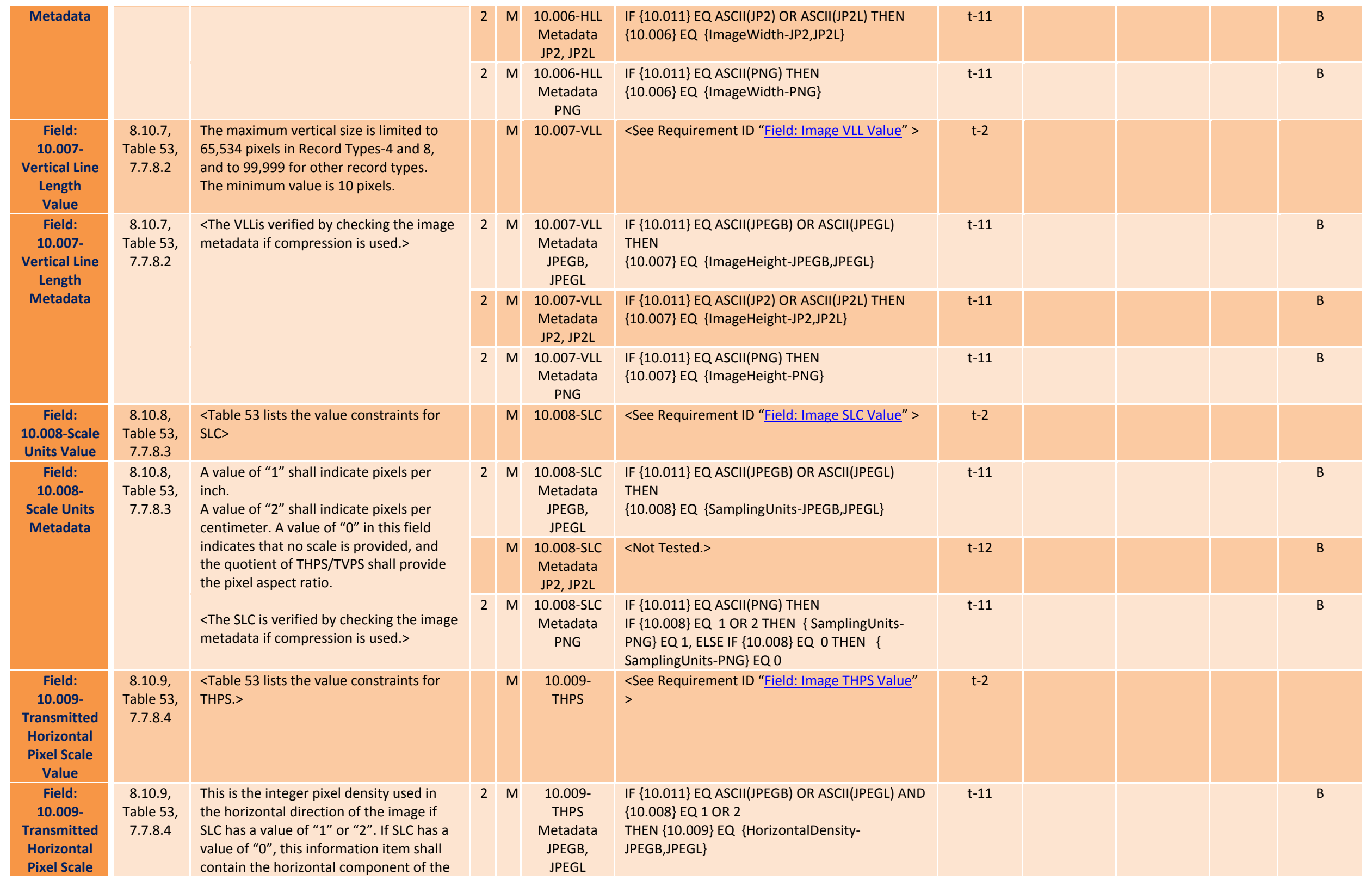




\begin{tabular}{|c|c|c|c|c|c|c|c|c|}
\hline \multirow[t]{5}{*}{ Metadata } & & $\begin{array}{l}\text { pixel aspect ratio, up to } 5 \text { digits. } \\
<\text { The THPS is verified by checking the } \\
\text { image metadata if compression is used.> }\end{array}$ & & M & $\begin{array}{l}\text { 10.009- } \\
\text { THPS } \\
\text { Metadata } \\
\text { JP2, JP2L }\end{array}$ & $<$ Not Tested. $>$ & $\mathrm{t}-12$ & B \\
\hline & & & 2 & $M$ & $\begin{array}{l}\text { 10.009- } \\
\text { THPS } \\
\text { Metadata } \\
\text { PNG }\end{array}$ & $\begin{array}{l}\text { IF }\{10.011\} \text { EQ ASCII(PNG) AND }\{10.008\} \text { EQ } 1 \\
\text { THEN }\{10.009\} \text { EQ }\{\text { HorizontalDensity-PNG }\} \text { * } \\
0.0254 \text { (meters/inch), } \\
\text { ELSE IF } 10.011\} \text { EQ ASCII(PNG) AND }\{10.008\} \text { EQ } \\
2 \\
\text { THEN }\{10.009\} \text { EQ }\{\text { HorizontalDensity-PNG }\} \text { * } \\
0.01 \text { (meters/cm) }\end{array}$ & $\mathrm{t}-11$ & B \\
\hline & & & 2 & M & $\begin{array}{l}\text { 10.009- } \\
\text { THPS } \\
\text { Aspect } \\
\text { Ratio } \\
\text { Metadata } \\
\text { JPEGB, } \\
\text { JPEGL }\end{array}$ & $\begin{array}{l}\text { IF }\{10.011\} \text { EQ ASCII(JPEGB) OR ASCII(JPEGL) } \\
\text { AND }\{10.008\} \text { NEQ } 1 \text { OR } 2 \\
\text { THEN }\{10.009\} /\{10.010\} \text { EQ \{HorizontalDensity- } \\
\text { JPEGB,JPEGL\} / \{VerticalDensity-JPEGB,JPEGL\} }\end{array}$ & $\mathrm{t}-11$ & B \\
\hline & & & & $M$ & $\begin{array}{l}\text { 10.009- } \\
\text { THPS } \\
\text { Aspect } \\
\text { Ratio } \\
\text { Metadata } \\
\text { JP2, JP2L }\end{array}$ & $<$ Not Tested. $>$ & $\mathrm{t}-12$ & B \\
\hline & & & 2 & M & $\begin{array}{l}\text { 10.009- } \\
\text { THPS } \\
\text { Aspect } \\
\text { Ratio } \\
\text { Metadata } \\
\text { PNG }\end{array}$ & $\begin{array}{l}\text { IF }\{10.011\} \text { EQ ASCII(PNG) AND }\{10.008\} \text { NEQ } 1 \\
\text { OR } 2 \\
\text { THEN }\{10.009\} /\{10.010\} \text { EQ }\{\text { HorizontalDensity- } \\
\text { PNG } /\{\text { VerticalDensity-PNG }\}\end{array}$ & $\mathrm{t}-11$ & B \\
\hline $\begin{array}{c}\text { Field: } \\
10.010- \\
\text { Transmitted } \\
\text { Vertical } \\
\text { Pixel Scale } \\
\text { Value }\end{array}$ & $\begin{array}{c}\text { 8.10.10, } \\
\text { Table 53, } \\
\text { 7.7.8.5 }\end{array}$ & $\begin{array}{l}<\text { Table } 53 \text { lists the value constraints for } \\
\text { TVPS.> }\end{array}$ & & $M$ & $\begin{array}{l}10.010- \\
\text { TVPS }\end{array}$ & $\begin{array}{l}<\text { See Requirement ID “Field: Image TVPS Value” } \\
>\end{array}$ & $t-2$ & \\
\hline \multirow[t]{2}{*}{$\begin{array}{c}\text { Field: } \\
\text { 10.010- } \\
\text { Transmitted } \\
\text { Vertical } \\
\text { Pixel Scale } \\
\text { Metadata }\end{array}$} & \multirow[t]{2}{*}{$\begin{array}{c}8.10 .10 \\
\text { Table 53, } \\
7.7 .8 .5\end{array}$} & \multirow{2}{*}{$\begin{array}{l}\text { This is the integer pixel density used in } \\
\text { the Vertical direction of the image if SLC } \\
\text { has a value of " } 1 \text { " or " } 2 \text { ". If SLC has a } \\
\text { value of " } 0 \text { ", this information item shall } \\
\text { contain the Vertical component of the } \\
\text { pixel aspect ratio, up to } 5 \text { digits. } \\
<\text { The TVPS is verified by checking the } \\
\text { image metadata if compression is used.> }\end{array}$} & 2 & M & $\begin{array}{c}\text { 10.010- } \\
\text { TVPS } \\
\text { Metadata } \\
\text { JPEGB, } \\
\text { JPEGL }\end{array}$ & $\begin{array}{l}\text { IF }\{10.011\} \text { EQ ASCII(JPEGB) OR ASCII(JPEGL) AND } \\
\{10.008\} \text { EQ } 1 \text { OR } 2 \\
\text { THEN }\{10.010\} \text { EQ }\{\text { VerticalDensity- } \\
\text { JPEGB,JPEGL }\}\end{array}$ & $\mathrm{t}-11$ & B \\
\hline & & & & & $\begin{array}{l}\text { 10.010- } \\
\text { TVPS } \\
\text { Metadata } \\
\text { JP2, JP2L }\end{array}$ & $<$ Not Tested.> & $\mathrm{t}-12$ & B \\
\hline
\end{tabular}



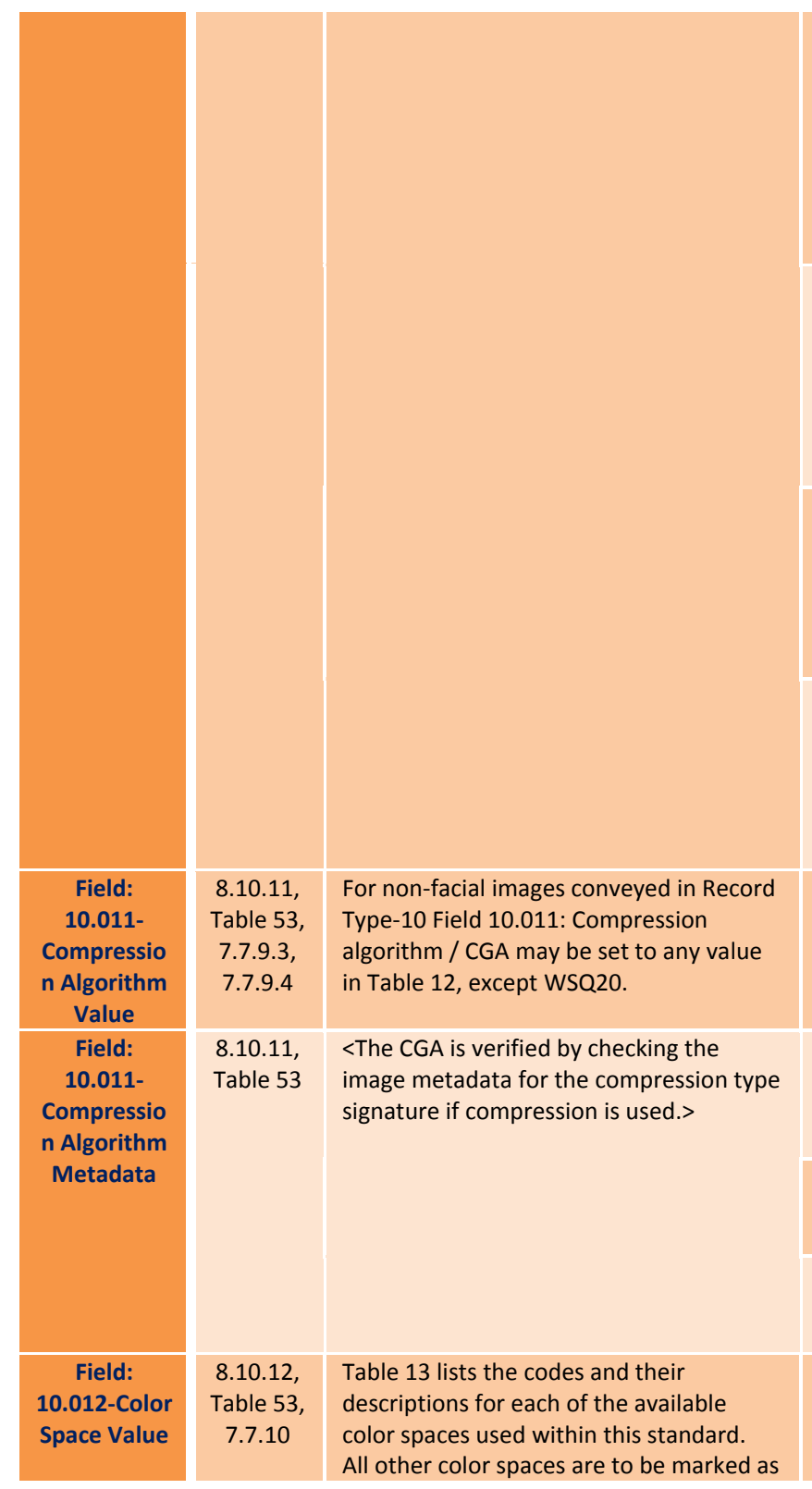

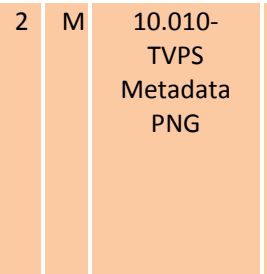

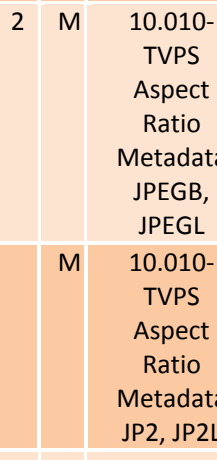

2 M 10.010-

TVPS

Aspect

Ratio

Metadata

M 10.011-CGA

2 M 10.011-

CGAMetad

ata JPEGB,

JPEGL

2 M $\begin{gathered}\text { 10.011-CGA } \\ \text { Metadata } \\ \text { JP2 JP2 }\end{gathered}$

2 M 10.011-CGA

Metadata

PNG

M 10.012-CSP
IF $\{10.011\}$ EQ ASCII(PNG) AND $\{10.008\}$ EQ 1 THEN $\{10.010\}$ EQ $\left\{\right.$ VerticalDensity-PNG ${ }^{*}$

0.0254 (meters/inch),

ELSE IF 10.011$\}$ EQ ASCII(PNG) AND $\{10.008\}$ EQ

THEN $\{10.010\}$ EQ $\{$ VerticalDensity-PNG $\}$ * 0.01 (meters/cm)

IF $\{10.011\}$ EQ ASCII(JPEGB) OR ASCII(JPEGL) AND

$\{10.008\}$ NEQ 1 OR 2

THEN $\{10.009\} /\{10.010\}$ EQ HHorizontalDensity-

JPEGB,JPEGL\} / \{VerticalDensity-JPEGB,JPEGL

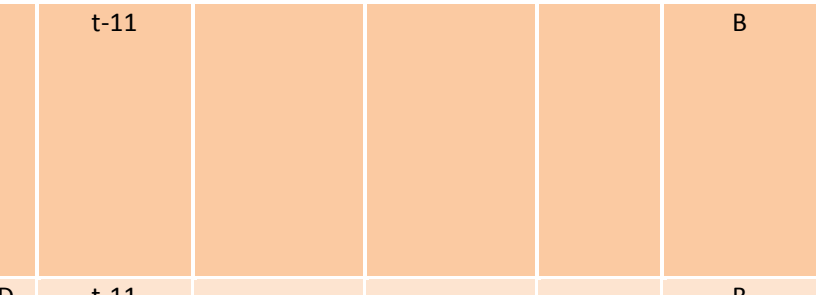

<Not Tested.>

IF $\{10.011\}$ EQ ASCII(PNG) AND $\{10.008\}$ NEQ 1

OR 2

THEN $\{10.009\} /\{10.010\}$ EQ $\{$ HorizontalDensity PNG $/$ \{ VerticalDensity-PNG $\}$

<See Requirement ID: “Field: Type10

Compression">

IF $\{10.011\}$ EQ ASCII(JPEGB) OR ASCII(JPEGL)

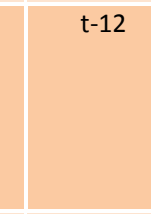

$\mathrm{t}-11$
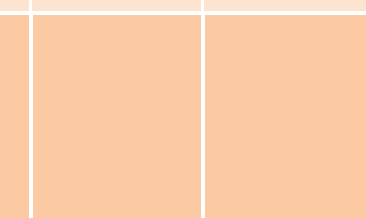

Present(SOI -JPEG,JPEGL)

IF $\{10.011\}$ EQ ASCII(JP2) OR ASCII(JP2L) THEN

Present(SigBox)

IF $\{10.011\}$ EQ ASCII(PNG) THEN

Present(PNGSig)

<See Requirement ID: “Field: Image CSP Value> 


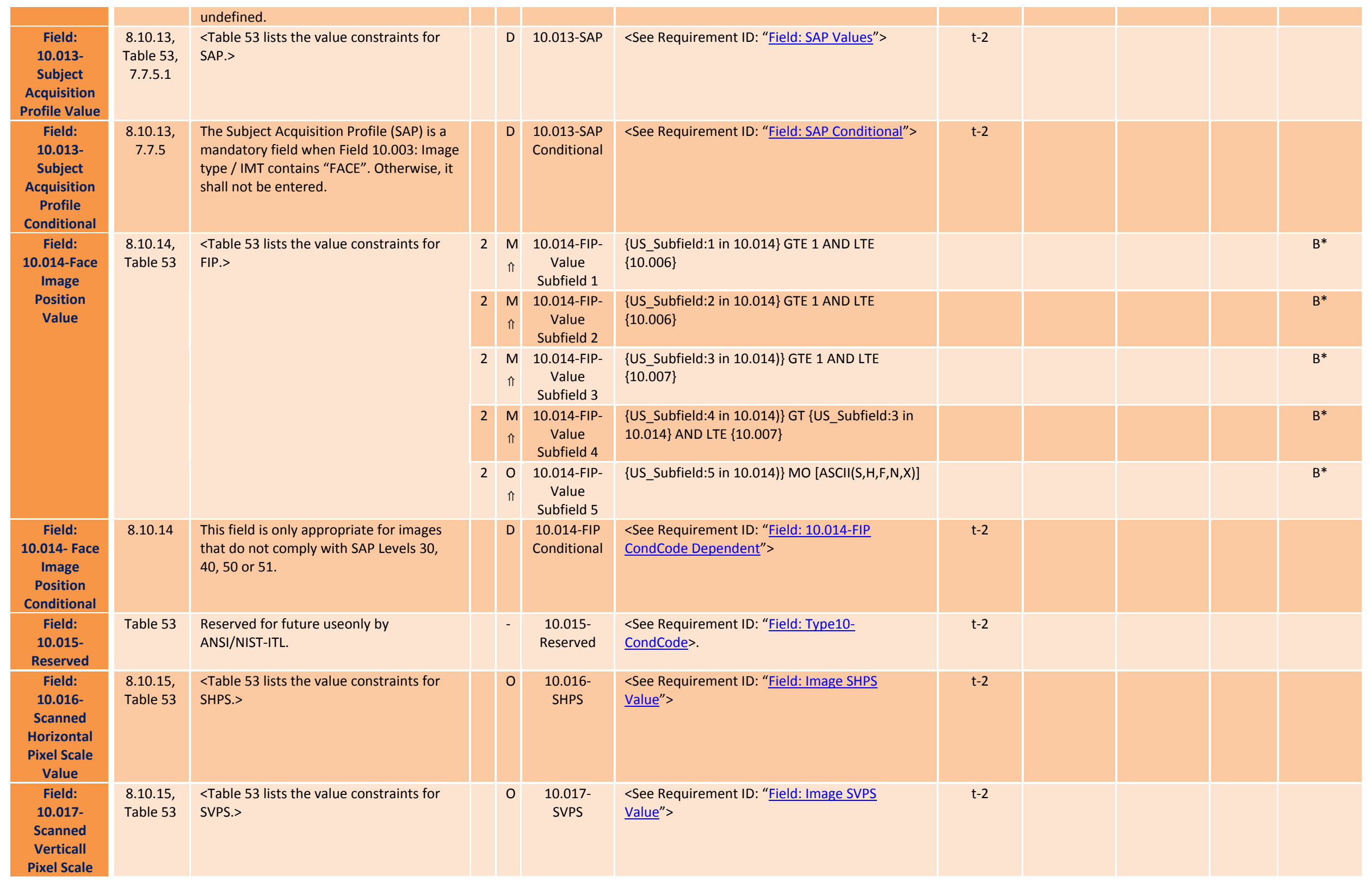




\begin{tabular}{|c|}
\hline Value \\
\hline $\begin{array}{l}\text { Field: } \\
\text { 10.018- } \\
\text { Distortion } \\
\text { Value }\end{array}$ \\
\hline $\begin{array}{l}\text { Field: } \\
\text { 10.019- } \\
\text { Lighting } \\
\text { Artifacts } \\
\text { Value }\end{array}$ \\
\hline $\begin{array}{c}\text { Field: } \\
10.020- \\
\text { Subject Pose } \\
\text { Value }\end{array}$ \\
\hline $\begin{array}{c}\text { Field: YAW } \\
\text { POA } \\
\text { Opposite }\end{array}$ \\
\hline $\begin{array}{c}\text { Field: } \\
\text { 10.021- Pose } \\
\text { Offset Angle } \\
\text { Value }\end{array}$ \\
\hline $\begin{array}{c}\text { Field: } \\
\text { 10.022- } \\
\text { Deprecated }\end{array}$ \\
\hline $\begin{array}{l}\text { Field: } \\
\text { 10.023- } \\
\text { Photo } \\
\text { Acquisition } \\
\text { Source } \\
\text { Value }\end{array}$ \\
\hline $\begin{array}{l}\text { Field: } \\
\text { 10.023- } \\
\text { Photo } \\
\text { Acquisition } \\
\text { Source } \\
\text { VENDOR }\end{array}$ \\
\hline $\begin{array}{l}\text { Field: } \\
\text { 10.023- } \\
\text { Photo } \\
\text { Acquisition }\end{array}$ \\
\hline
\end{tabular}

\begin{tabular}{|c|c|c|c|c|}
\hline \multirow[t]{3}{*}{$\begin{array}{l}8.10 .17 \\
\text { Table } 53\end{array}$} & \multirow[t]{3}{*}{$\begin{array}{l}<\text { Table } 53 \text { lists the value constraints for } \\
\text { DIST.> }\end{array}$} & 1 & $\begin{array}{c}M \\
\Uparrow\end{array}$ & $\begin{array}{l}\text { 10.018- } \\
\text { DIST-Value } \\
\text { Subfield } 1\end{array}$ \\
\hline & & 1 & $\begin{array}{c}M \\
\Uparrow\end{array}$ & $\begin{array}{l}\text { 10.018- } \\
\text { DIST- Value } \\
\text { Subfield } 2\end{array}$ \\
\hline & & 1 & $\begin{array}{l}M \\
\Uparrow\end{array}$ & $\begin{array}{l}\text { 10.018- } \\
\text { DIST- Value } \\
\text { Subfield } 3\end{array}$ \\
\hline $\begin{array}{l}8.10 .18 \\
\text { Table } 53\end{array}$ & $\begin{array}{l}<\text { Table } 53 \text { lists the value constraints for } \\
\text { LAF.> }\end{array}$ & 1 & D & 10.019-LAF \\
\hline $\begin{array}{l}\text { 8.10.19, } \\
\text { Table } 56\end{array}$ & $\begin{array}{l}\text { When included, this field shall contain } \\
\text { one character code selected from Table } \\
56 \text { to describe the pose of the subject. }\end{array}$ & 1 & D & 10.020-POS \\
\hline 8.10 .19 & $\begin{array}{l}\text { Note that the offset angle in Field } 10.021 \text { : } \\
\text { Pose offset angle / POA is opposite from } \\
\text { the yaw angle in Field } 10.025 \text { as indicated } \\
\text { by a minus sign. }\end{array}$ & 2 & $\mathrm{D}$ & $\begin{array}{l}\text { Fields- YAW } \\
\text { POA } \\
\text { Opposite }\end{array}$ \\
\hline $\begin{array}{l}8.10 .20 \\
\text { Table } 53\end{array}$ & $\begin{array}{l}\text { When included, this field shall contain } \\
\text { one character code selected from Table } \\
56 \text { to describe the pose of the subject. }\end{array}$ & 1 & D & $\begin{array}{l}10.021- \\
\text { POA }\end{array}$ \\
\hline Table 53 & Not to be used in new transactions. & & - & $\begin{array}{c}10.022- \\
\text { Deprecated }\end{array}$ \\
\hline $\begin{array}{l}8.10 .21 \\
\text { Table } 53, \\
\text { Table } 57\end{array}$ & $\begin{array}{l}\text { When included, the first information item } \\
\text { in this field shall contain an attribute code } \\
\text { selected from Table } 57 \text { to describe the } \\
\text { source of captured image data. }\end{array}$ & 1 & $\begin{array}{l}M \\
\Uparrow\end{array}$ & 10.023-PAS \\
\hline $\begin{array}{l}8.10 .21 \\
\text { Table } 53 \\
\text { Table } 57\end{array}$ & $\begin{array}{l}\text { When "VENDOR" is } \\
\text { specified, a second information item may } \\
\text { be entered with up to } 64 \text { characters to } \\
\text { describe the specific source. }\end{array}$ & & $\mathrm{D}$ & $\begin{array}{l}\text { 10.023-PAS } \\
\text { VENDOR }\end{array}$ \\
\hline $\begin{array}{l}8.10 .21 \\
\text { Table } 53, \\
\text { Table } 57\end{array}$ & $\begin{array}{l}\text { When "Type- } 20 \text { " is selected, then Field } \\
\text { 10.997: Source representation / SOR shall } \\
\text { be contained in this record, and the } \\
\text { corresponding Record Type- } 20 \text { shall be }\end{array}$ & 2 & D & $\begin{array}{c}\text { 10.023-PAS } \\
\text { Type-20 }\end{array}$ \\
\hline
\end{tabular}

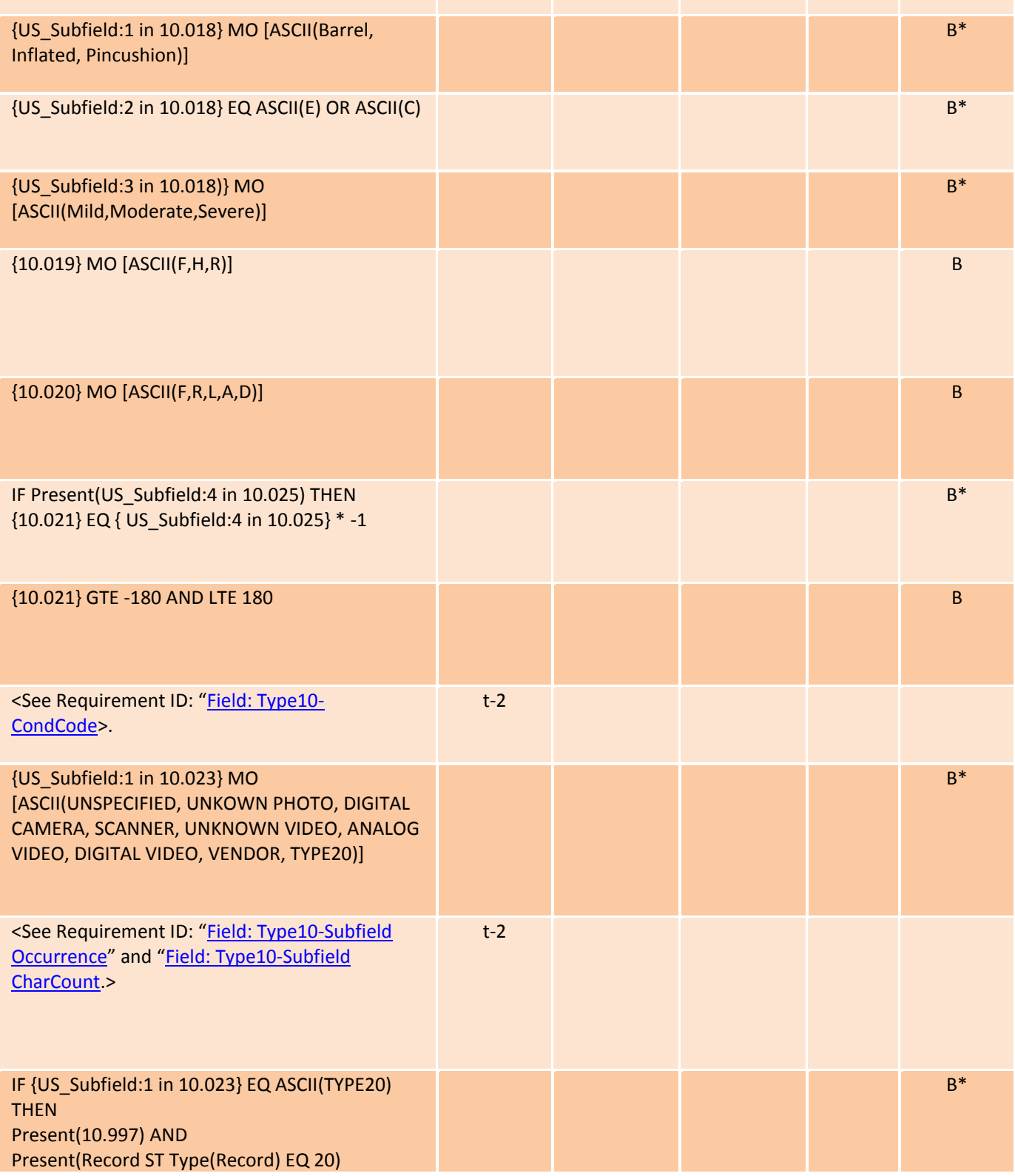




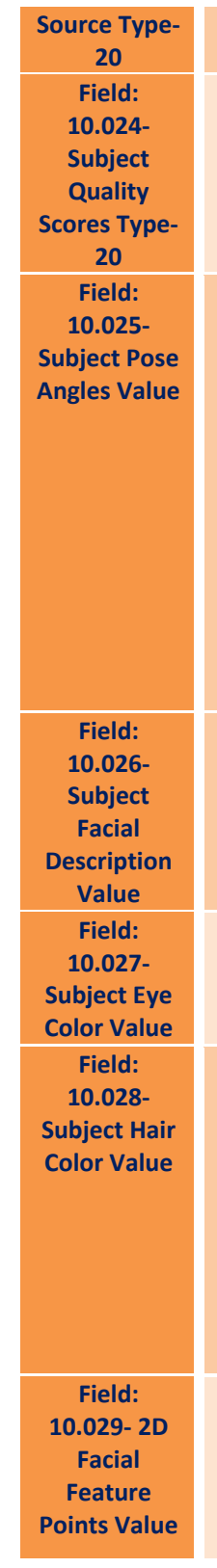

\begin{tabular}{|c|c|}
\hline & included in the transaction. \\
\hline $\begin{array}{c}\text { 8.10.22, } \\
\text { Table 53, } \\
7.7 .7\end{array}$ & $\begin{array}{l}<\text { Table } 53 \text { lists the value constraints for } \\
\text { SQS.> }\end{array}$ \\
\hline $\begin{array}{l}8.10 .23 \\
\text { Table } 53\end{array}$ & $\begin{array}{l}<\text { Table } 53 \text { lists the value constraints for } \\
\text { SPA.> }\end{array}$ \\
\hline $\begin{array}{l}8.10 .24, \\
\text { Table 53, } \\
\text { Table 58 }\end{array}$ & $\begin{array}{l}\text { The value should be selected from the } \\
\text { "Attribute code" column of Table } 58 \text {. }\end{array}$ \\
\hline $\begin{array}{l}8.10 .25, \\
\text { Table 53, } \\
\text { Table } 14\end{array}$ & $\begin{array}{l}<\text { Table } 53 \text { lists the value constraints for } \\
\text { SEC. }>\end{array}$ \\
\hline $\begin{array}{l}8.10 .26 \\
\text { Table 53, } \\
\text { Table 59 }\end{array}$ & $\begin{array}{l}<\text { Table } 53 \text { lists the value constraints for } \\
\text { SHC.> } \\
\text { When the subject is predominantly bald, } \\
\text { but hair color is discernible, then the } \\
\text { appropriate hair color attribute code shall } \\
\text { follow "BAL" in a second entry. } \\
\text { For streaked hair, use "STR" in the first } \\
\text { entry; use the second entry to describe } \\
\text { the principal color of the hair. }\end{array}$ \\
\hline $\begin{array}{l}8.10 .27 \\
\text { Table } 53\end{array}$ & $\begin{array}{l}<\text { Table } 53 \text { lists the value constraints for } \\
\text { FFP.> } \\
\text { The first information item, feature point } \\
\text { type / FPT is a one character value. It is }\end{array}$ \\
\hline
\end{tabular}

D $10.024-S Q S$

<See Requirement ID: "Field: Sample Quality Subfield 1" and "Field: Sample Quality Subfield 2" and "Field: Sample Quality Subfield 3".>

1 M 10.025$\Uparrow$ SPA- Value

1 M 10.025-

$\Uparrow$ SPA-Value Subfield 2

1 M 10.025$\Uparrow \quad$ SPA- Value

10 10.025$\Uparrow$ SPA- Value Subfield 4

to 6

D $\quad 10.026-S X S$

D $10.027-S E C$

1 M 10.028-SHC $\Uparrow$

M 10.029-FFP- ForEach(RS_Subfield in 10.029)

Value

Subfield 1 \{US_Subfield:1 in RS_Subfield\} EQ 1 OR 2 \}

M 10.029-FFP- ForEach(RS_Subfield in 10.029)
\{US Subfield:1 in 10.025\} GTE -180 AND LTE 180

US Subfield:2 in 10.025\} GTE -90 AND LTE 90

US_Subfield:3 in 10.025)\} GTE -180 AND LTE 180

\section{\{US Subfields:4 to 6 in 10.025)\} GTE 0 AND LTE} 90

$<$ Cannot check for values because the standard allows user-defined Alphabetic Text. See Requirement ID: "Field: Type10-Subfield

CharType" and "Field: Type10-Subfield

CharCount">

<See Requirement ID: “Field: Image ECL Value”>.

$\mathrm{t}-2$

\{US_Subfield:1 in 10.028\} MO [ASCII(XXX, BAL, BLK, BLN, BRO, GRY, RED, SDY, WHI, BLU, GRN, ONG, PNK, PLE, STR)]

AND

\{US_Subfield:2 in 10.028\} MO [ASCII(XXX, BLK, BLN, BRO, GRY, RED, SDY, WHI, BLU, GRN, ONG, PNK, PLE)] 


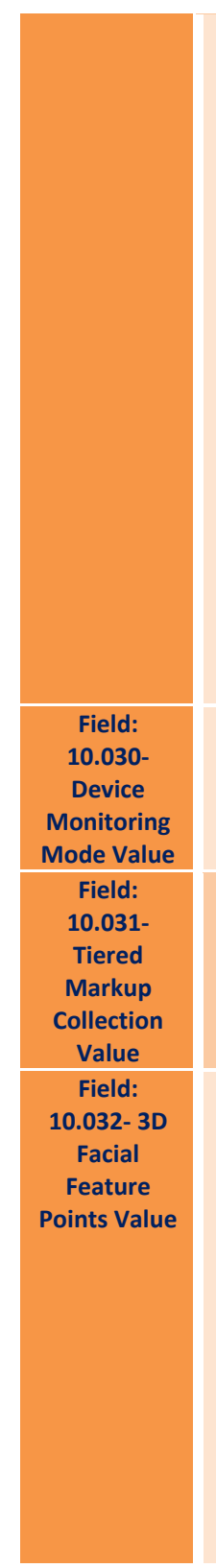

mandatory. It shall be either

$1=$ Denoting an MPEG4 Feature point. 2 = Anthropometric landmark. (This is new to this version).

The second information item, feature point code / FPC is 3 to 5 characters. If FPT is 1, this information item shall be "A.B" with $A$ and $B$ defined in

Section 8.10.27.1 and illustrated in Figure 12. If FPT is 2 , the codes are entered as shown in the "Feature Point ID" column of Table 61 . This is one to four alphabetic characters.

8.10.28, <Table 53 lists the value constraints for Table 53, DMM.>

8.10.29, <Table 53 lists the value constraints for

TMC.>

$<$ Table 53 lists the value constraints for 3DF.>

The first information item, feature point type / FPT is a one character value. It is mandatory. It shall be either

1 = Denoting an MPEG4 Feature point,

but using a $Z$ coordinate

2 = Anthropometric landmark, with a Z coordinate.

The second information item, feature point code / FPC is 3 to 5 characters. If FPT is 1 , this information item shall be "A.B" with $A$ and $B$ defined in

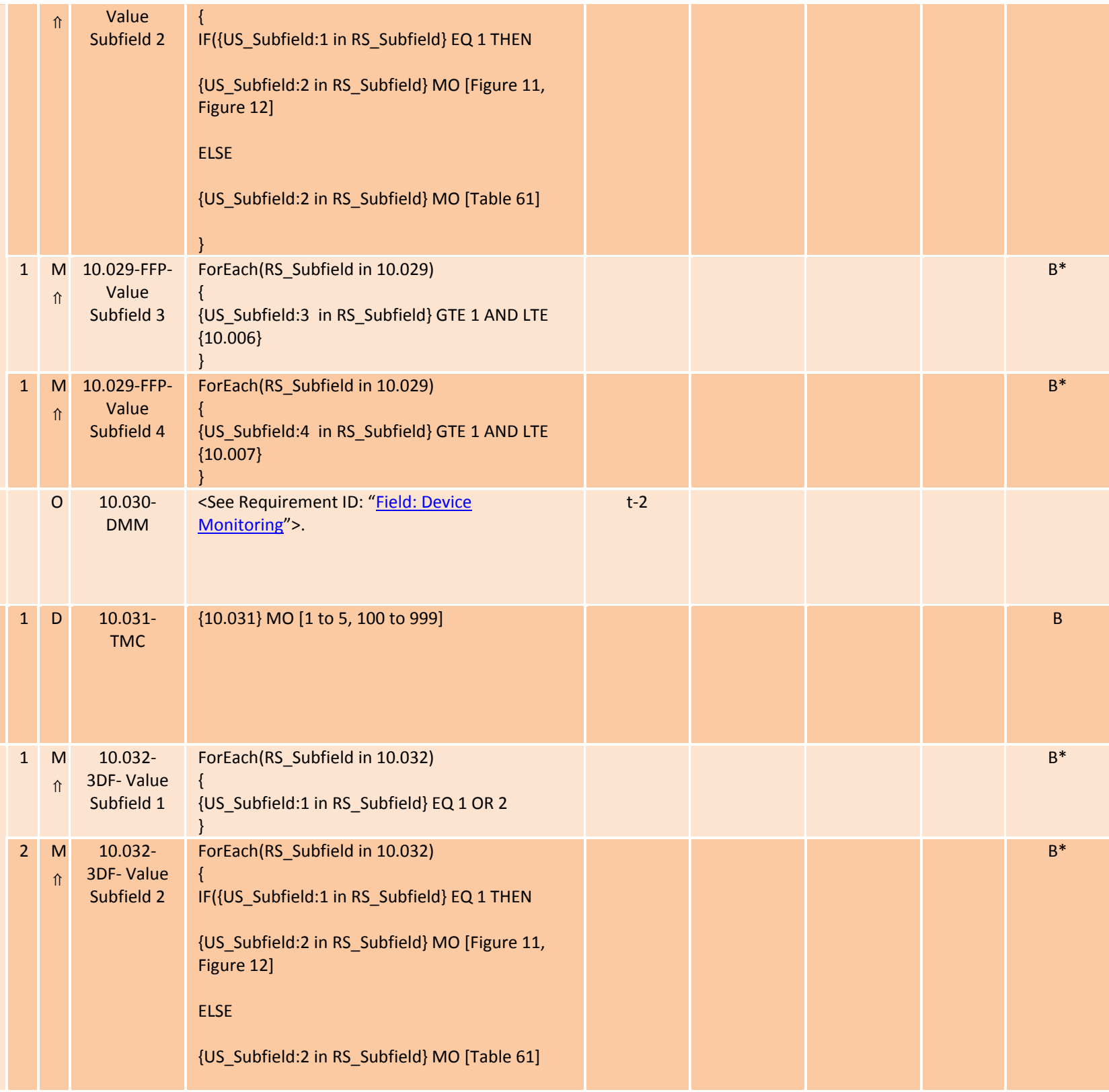




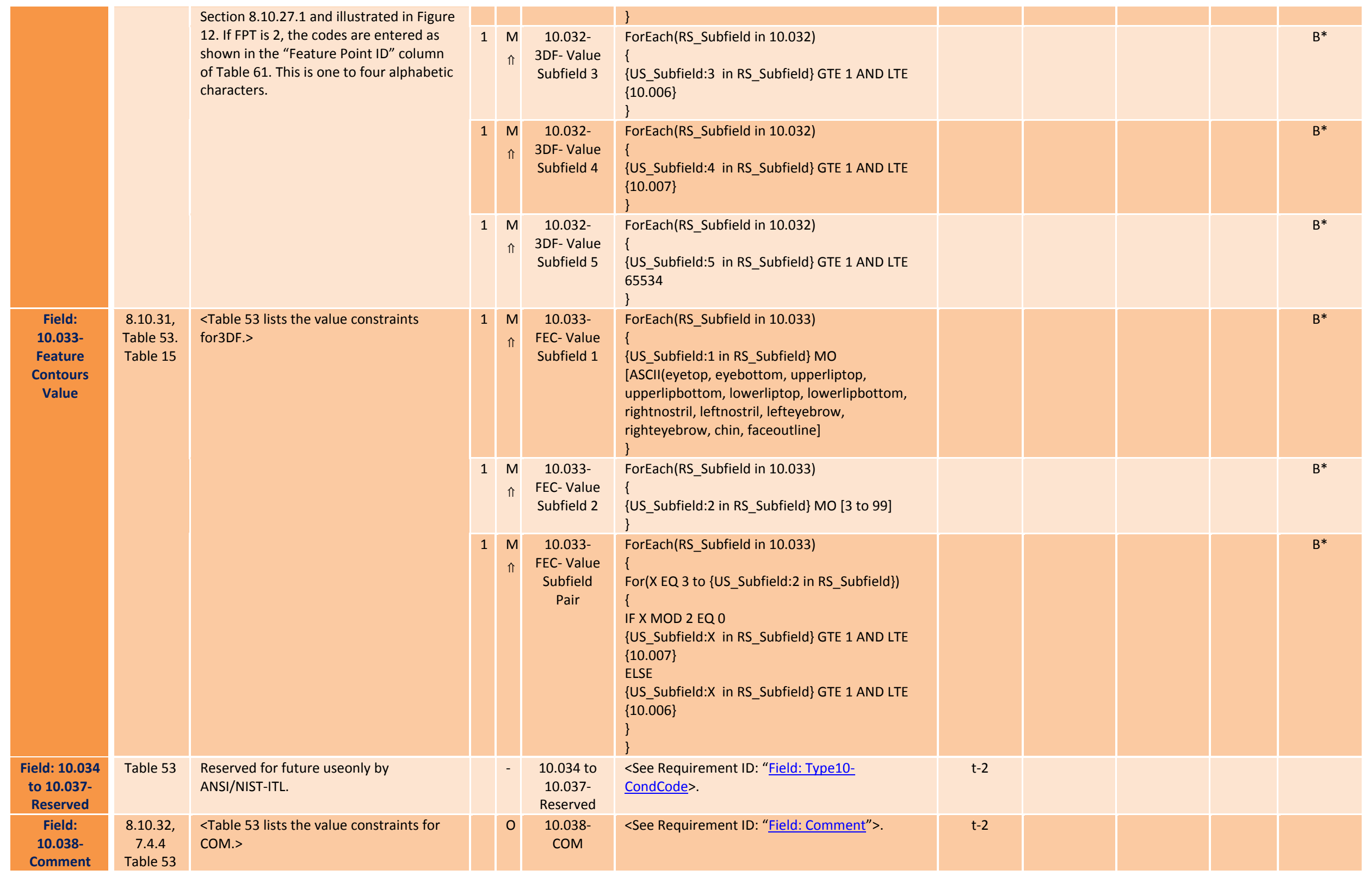




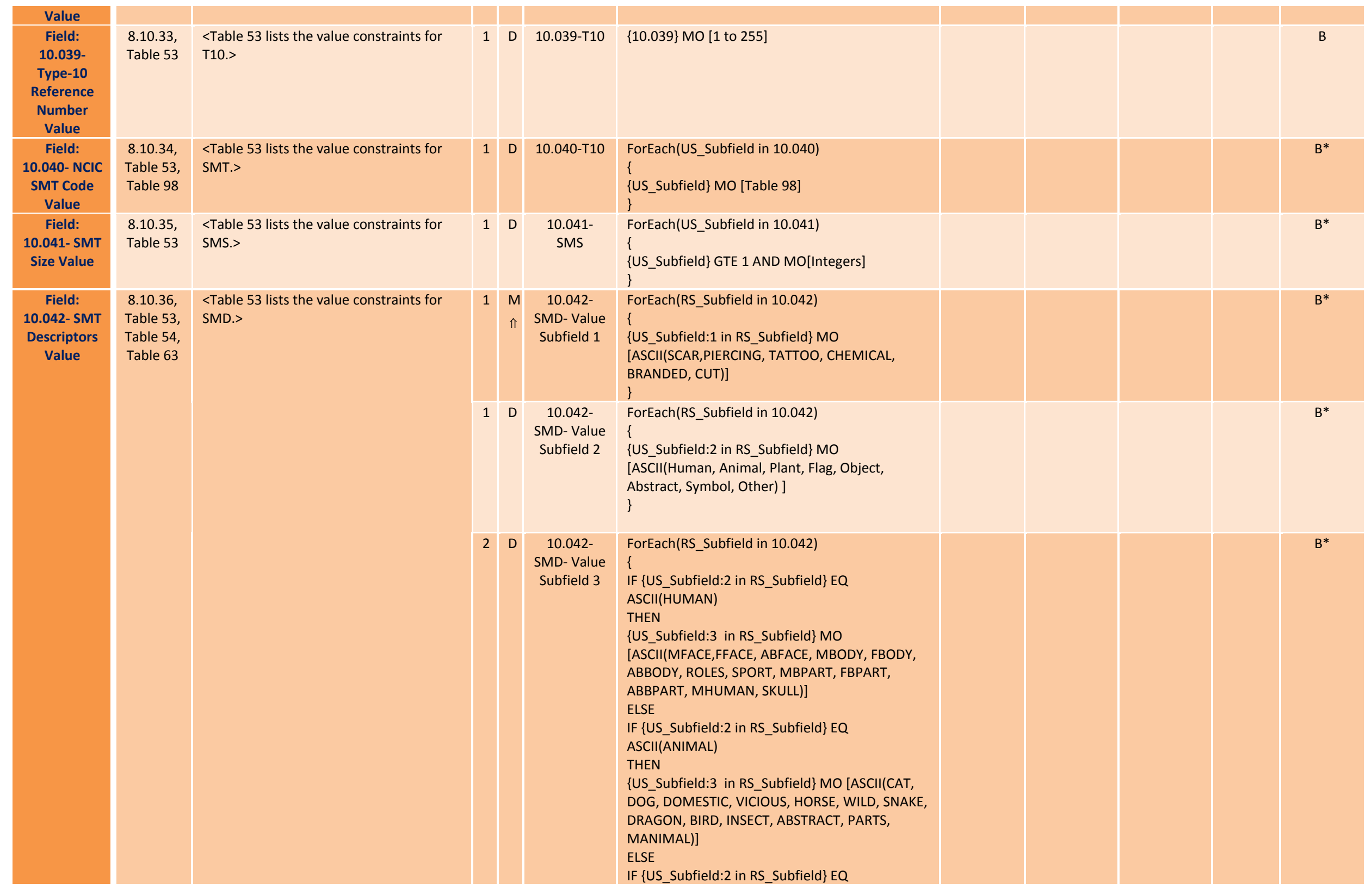




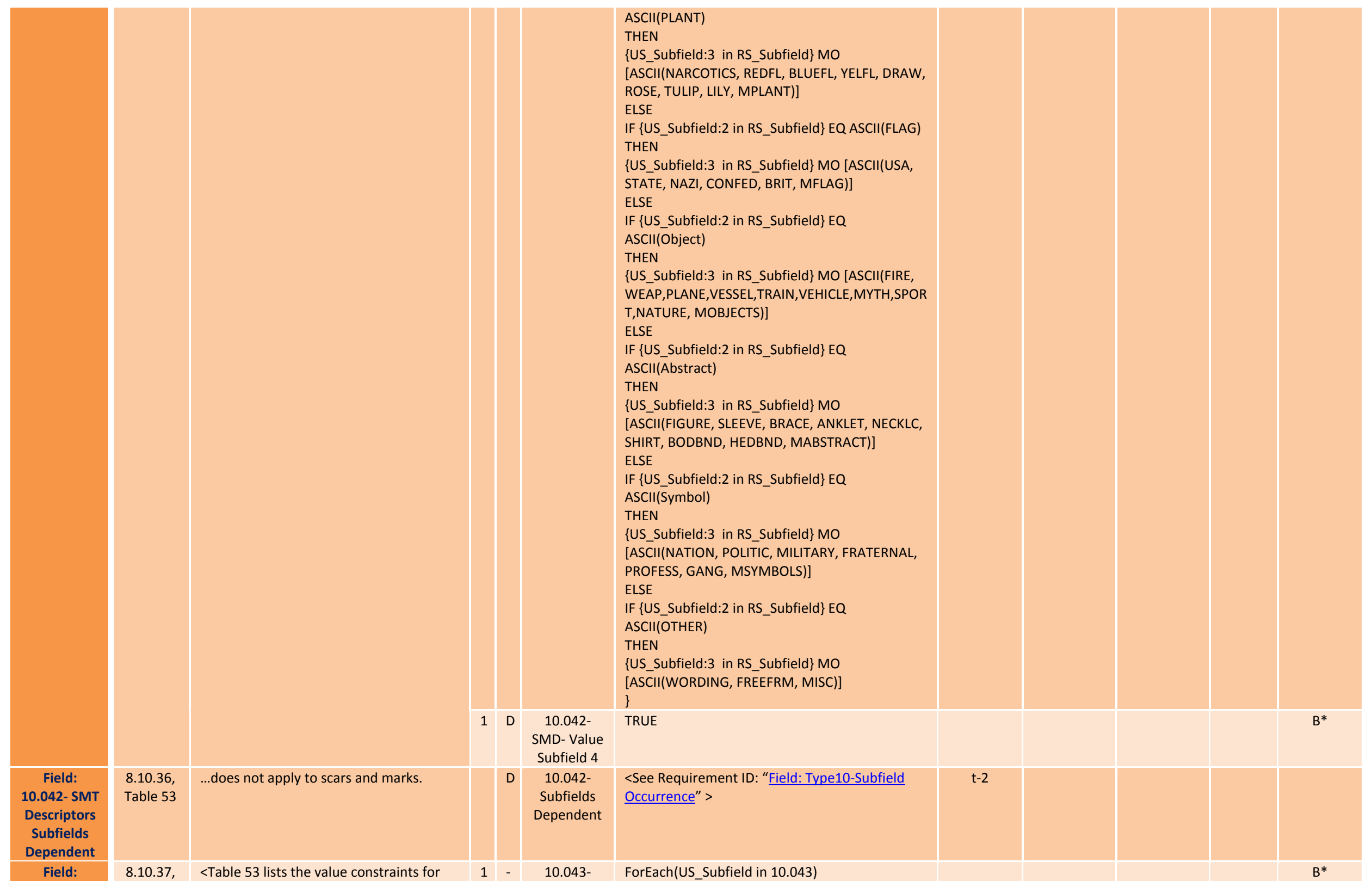




\begin{tabular}{|c|c|c|c|c|c|c|c|c|}
\hline $\begin{array}{l}\text { 10.043- } \\
\text { Tattoo Color } \\
\text { Value }\end{array}$ & Table 53 & COL.> & & & COL-Value & $\begin{array}{l}\{ \\
\{\text { US_Subfield }\} \text { MO [BLACK, BROWN, GRAY, BLUE, } \\
\text { GREEN, ORANGE, PURPLE, RED, YELLOW, WHITE, } \\
\text { MULTI, OUTLINE] } \\
\}\end{array}$ & & \\
\hline $\begin{array}{l}\text { Field: } \\
\text { 10.044- } \\
\text { Image } \\
\text { Transform } \\
\text { Value }\end{array}$ & $\begin{array}{l}8.10 .38, \\
\text { Table 53, } \\
\text { Table } 65\end{array}$ & $\begin{array}{l}<\text { Table } 53 \text { lists the value constraints for } \\
\text { ITX.> }\end{array}$ & 1 & $\begin{array}{l}M \\
\Uparrow\end{array}$ & $\begin{array}{l}\text { 10.044-ITX- } \\
\text { Value }\end{array}$ & $\begin{array}{l}\text { ForEach(US_Subfield in 10.044) } \\
\{ \\
\text { \{US_Subfield\} MO [AGE, AXIS, COLORSHIFT, } \\
\text { CONTRAST, CROP, DIST, DOWNSAMPLE, GRAY, } \\
\text { ILLUM, IMGFUSE, INTERPOLATE, MULTCOMP, } \\
\text { MULTIVIEW, POSE, ROTATE, SNIR, SUPERRES, } \\
\text { WHITE] } \\
\text { \} }\end{array}$ & & $\mathrm{B}^{*}$ \\
\hline \multirow[t]{4}{*}{$\begin{array}{l}\text { Field: } \\
\text { 10.045- } \\
\text { Occlusions } \\
\text { Value }\end{array}$} & \multirow[t]{4}{*}{$\begin{array}{l}8.10 .30 \\
\text { Table 17, } \\
\text { Table } 18\end{array}$} & \multirow[t]{4}{*}{$\begin{array}{l}<\text { Table } 53 \text { lists the value constraints for } \\
\text { OCC.> }\end{array}$} & 1 & $\begin{array}{l}\mathrm{M} \\
\Uparrow\end{array}$ & $\begin{array}{l}10.045- \\
\text { OCC- Value } \\
\text { Subfield } 1\end{array}$ & $\begin{array}{l}\text { ForEach(RS_Subfield in 10.045) } \\
\{ \\
\{\text { US_Subfield:1 in RS_Subfield }\} \text { MO [ASCII(T, I, L, } \\
\text { S)] } \\
\}\end{array}$ & & $\mathrm{B}^{*}$ \\
\hline & & & 1 & $\begin{array}{c}M \\
\Uparrow\end{array}$ & $\begin{array}{l}10.045- \\
\text { OCC- Value } \\
\text { Subfield } 2\end{array}$ & $\begin{array}{l}\text { ForEach(RS_Subfield in 10.045) } \\
\{ \\
\{\text { US_Subfield:2 in RS_Subfield }\} \text { MO } \\
{[\text { ASCII(H,S,C,R,O)] }} \\
\}\end{array}$ & & $\mathrm{B}^{*}$ \\
\hline & & & 1 & $\begin{array}{c}M \\
\Uparrow\end{array}$ & $\begin{array}{l}10.045- \\
\text { OcC- Value } \\
\text { Subfield } 3\end{array}$ & $\begin{array}{l}\text { ForEach(RS_Subfield in 10.045) } \\
\{ \\
\{\text { US_Subfield:3 in RS_Subfield }\} \text { GTE } 2 \text { AND LTE } 99 \\
\}\end{array}$ & & $\mathrm{B}^{*}$ \\
\hline & & & 1 & $\begin{array}{l}M \\
\Uparrow\end{array}$ & $\begin{array}{l}\text { 10.045- } \\
\text { OCC- Value } \\
\text { Subfield } \\
\text { Pairs }\end{array}$ & $\begin{array}{l}\text { ForEach(RS_Subfield in 10.045) } \\
\{ \\
\text { For(X EQ } 1 \text { to (US_Subfield:3 in RS_Subfield }\}) \\
\{ \\
\text { IF X MOD } 2 \text { EQ } 0 \\
\{\text { US_Subfield:X in RS_Subfield }\} \text { GTE } 1 \text { AND LTE } \\
\{10.007\} \\
\text { ELSE } \\
\{\text { US_Subfield:X in RS_Subfield }\} \text { GTE } 1 \text { AND LTE } \\
\{10.006\} \\
\} \\
\}\end{array}$ & & $\mathrm{B}^{*}$ \\
\hline $\begin{array}{l}\text { Field: } 10.046 \\
\text { to } 10.199- \\
\text { Reserved }\end{array}$ & Table 53 & $\begin{array}{l}\text { Reserved for future useonly by } \\
\text { ANSI/NIST-ITL. }\end{array}$ & & - & $\begin{array}{l}10.046 \text { to } \\
10.199- \\
\text { Reserved }\end{array}$ & $\begin{array}{l}\text { <See Requirement ID: "Field: Type10- } \\
\text { CondCode>. }\end{array}$ & $\mathrm{t}-2$ & \\
\hline $\begin{array}{l}\text { Field: } 10.200 \\
\text { to } 10.900- \\
\text { User } \\
\text { Defined }\end{array}$ & Table 53 & User Defined Fields & - & - & $\begin{array}{l}10.200 \text { to } \\
10.900- \\
\text { User } \\
\text { Defined }\end{array}$ & TRUE & & B \\
\hline
\end{tabular}




\begin{tabular}{|c|}
\hline Field: 10.901 \\
\hline Reserved \\
\hline Field: \\
10.902- \\
Annotated \\
Information \\
Value \\
\hline Field: \\
\hline $10.903-$ \\
\hline Device \\
Unique \\
Identifier \\
Value \\
\hline Field: \\
\hline $10.904-$ \\
\hline Make/Mode \\
I/Serial \\
Number \\
Value \\
\hline Field: 10.905 \\
to 10.994- \\
Reserved \\
\hline Field: \\
\hline $10.995-$ \\
\hline Associated \\
Context \\
Value \\
\hline Field: \\
10.996- \\
Hash Value \\
\hline Field: \\
10.997- \\
Source \\
Representati \\
on Value \\
\hline Field: \\
10.998- \\
Geographic \\
Sample \\
Acquisition \\
Location \\
Value \\
\hline Field: \\
10.999- \\
Image Data \\
Valid \\
\hline
\end{tabular}

10.901-

Reserved

O 10.902 -

ANN-Value

operations performed on the original

source in order

to prepare it for inclusion in a biometric

record type. See Section 7.4.1.

8.10.42, This is an optional field. See Section

7.7.1.1.

o 10.903-DUI

Value

8.10.43,

Table 53

This is an optional field. See Section

7.7.1.2.

Table 53

Reserved for future useonly by

ANSI/NIST-ITL.

8.10.44, See Section 7.3.3

Table 53

8.45

8.10.45, See Section 7.5.2

Table 53

8.10.46,

Table 53

See Section 7.3.2

8.10.47, See Section 7.7.3

Table 53

.

8.10.48, This is a mandatory field contains the

7.7.9.4, image.

Table 53

For non-facial images conveyed in Record

O $10.904-$ MMS Value

10.905 to

10.994-

10.995-ASC

Value

O 10.996-HAS

10.998-

GEO Value

Uncompres

sed Valid
<See Requirement ID: "Field: Type10CondCode>.

<See Requirement ID: “Field: xx.902-ANN” >.

<See Requirement ID: "Field: Device ID" >.

$\mathrm{t}-2$

quirement ID: "Field: $x \times 902-A N{ }^{\prime \prime}>$.

"Fier

<See Requirement IDs: "Field: xx.995-ASC" and

"Field: xx.995-ASC-ACN" and

"Field: xx.995-ASC-ASP">.

<See Requirement ID: "Field: HAS">

$-2$

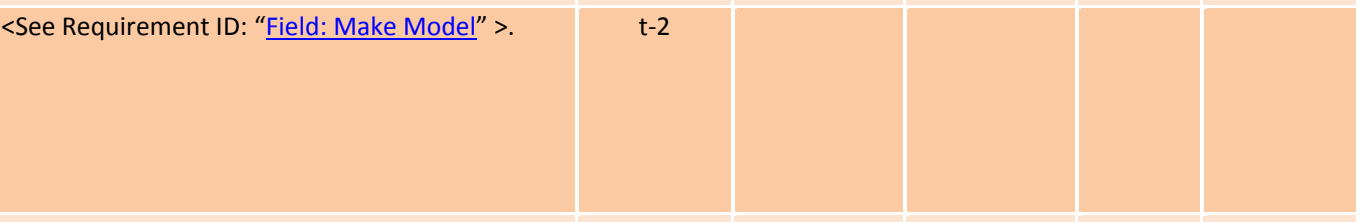

<See Requirement ID: “Field: Type10-

$\mathrm{t}-2$

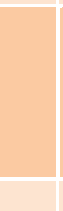

<See Requirement IDs: “Field: xx.997-SOR" and t-2

"Field: xx.997-SOR-SRN" and

"Field: XX.997-SOR-RSP">.

<See Requirement IDs: “Field: Geographic",

"Field: Geographic-Conditional", "Field:

Geographic-Subfield 1" through "Field:

Geographic-Values-SubField 15" >.

2 M 10.999- IF $\{10.011\}$ EQ ASCII(NONE) THEN

DATA Length(10.999) EQ 10.006 $\}$ \{10.007 $\}$ 
2 M 10.999DATA JPEGDATA JPEGJPEGL Valid

IF $\{10.011\}$ EQ ASCII(JPEGB) OR ASCII(JPEGL) THEN

Present(JFIF,

SOI-JPEGB,JPEGL,

SOF-JPEGB,JPEGL,

EOI-JPEG, JPEGL)

2 M 10.999- IF $\{10.011\}$ EQ ASCII(JP2) OR ASCII(JP2L) THEN

DATA JP2-

JP2L Valid

2 M 10.999-

DATA PNG

Valid

HeadBox,

ImgBox)

IF $\{10.011\}$ EQ ASCII(PNG) THEN

Present(PNGSig,

IHDR,

IDAT,

IEND) 
Table C.10 - Assertions for Record Type 11 - Reserved for Voice

\begin{tabular}{|c|c|c|c|c|c|c|c|c|c|c|c|}
\hline $\begin{array}{c}\text { Requireme } \\
\text { nt } \\
\text { ID }\end{array}$ & $\begin{array}{l}\text { Referen } \\
\text { ce in } \\
\text { Base } \\
\text { Standar } \\
\quad \text { d }\end{array}$ & $\begin{array}{l}\text { Requirement } \\
\text { Summary }\end{array}$ & $\begin{array}{l}\text { L } \\
\text { e } \\
\text { v } \\
\text { e } \\
\text { I }\end{array}$ & $\begin{array}{l}\mathrm{s} \\
\mathrm{t} \\
\mathrm{a} \\
\mathrm{t} \\
\mathrm{u} \\
\mathrm{s}\end{array}$ & $\begin{array}{l}\text { Assertion } \\
\text { ID }\end{array}$ & $\begin{array}{l}\text { Test } \\
\text { Assertion }\end{array}$ & $\begin{array}{l}\text { Test } \\
\text { Note }\end{array}$ & $\begin{array}{l}\text { Implemen } \\
\text { tation } \\
\text { Support }\end{array}$ & $\begin{array}{l}\text { Supporte } \\
\text { d Range }\end{array}$ & $\begin{array}{c}\text { Test } \\
\text { Result }\end{array}$ & $\begin{array}{l}\text { Applicab } \\
\text { ility }\end{array}$ \\
\hline \multicolumn{12}{|c|}{ 8.11: Record Type-11: Reserved for voice } \\
\hline $\begin{array}{l}\text { Transaction: } \\
\text { Type11 Zero } \\
\text { Occurrences }\end{array}$ & 8.11 & $\begin{array}{l}\text { Reserved for voice. A committee was } \\
\text { established at the second Workshop for } \\
\text { this version of the standard, } \\
\text { held March 1-3, } 2011 \text { to develop } \\
\text { specifications for this record type. }\end{array}$ & & $M$ & $\begin{array}{c}\text { Type11- } \\
\text { Zero } \\
\text { Occurrence } \\
\text { s }\end{array}$ & $\begin{array}{l}\text { <See Requirement ID "Transaction: Reserved } \\
\text { Records"> }\end{array}$ & $t-2$ & & & & \\
\hline
\end{tabular}

Table C.11 - Assertions for Record Type 12 - Reserved for Dental Records

\begin{tabular}{|c|c|c|c|c|c|c|c|c|c|c|c|}
\hline $\begin{array}{c}\text { Requireme } \\
\text { nt } \\
\text { ID }\end{array}$ & $\begin{array}{l}\text { Referen } \\
\text { ce in } \\
\text { Base } \\
\text { Standar } \\
\text { d }\end{array}$ & $\begin{array}{l}\text { Requirement } \\
\text { Summary }\end{array}$ & $\begin{array}{l}\text { L } \\
\text { e } \\
\text { v } \\
\text { e } \\
\text { I }\end{array}$ & $\begin{array}{l}\mathrm{s} \\
\mathrm{t} \\
\mathrm{a} \\
\mathrm{t} \\
\mathrm{u} \\
\mathrm{s}\end{array}$ & $\begin{array}{l}\text { Assertion } \\
\text { ID }\end{array}$ & $\begin{array}{l}\text { Test } \\
\text { Assertion }\end{array}$ & $\begin{array}{l}\text { Test } \\
\text { Note }\end{array}$ & $\begin{array}{l}\text { Implemen } \\
\text { tation } \\
\text { Support }\end{array}$ & $\begin{array}{c}\text { Supporte } \\
\text { d Range }\end{array}$ & $\begin{array}{c}\text { Test } \\
\text { Result }\end{array}$ & $\begin{array}{c}\text { Applicab } \\
\text { ility }\end{array}$ \\
\hline \multicolumn{12}{|c|}{ 8.12: Record Type-12: Reserved for dental records } \\
\hline $\begin{array}{l}\text { Transaction: } \\
\text { Type12 Zero } \\
\text { Occurrences }\end{array}$ & 8.12 & $\begin{array}{l}\text { Reserved for dental records. A committee } \\
\text { was established at the second Workshop } \\
\text { for this version of the standard, } \\
\text { held March 1-3, } 2011 \text { to develop } \\
\text { specifications for this record type. }\end{array}$ & & $M$ & $\begin{array}{c}\text { Type12- } \\
\text { Zero } \\
\text { Occurrence } \\
\text { s }\end{array}$ & $\begin{array}{l}\text { <See Requirement ID "Transaction: Reserved } \\
\text { Records" }\end{array}$ & $t-2$ & & & & \\
\hline
\end{tabular}


Table C.12 - Assertions for Record Type 13 - Friction-Ridge Latent Image Record

\begin{tabular}{|c|c|c|c|c|c|c|c|c|c|c|c|}
\hline $\begin{array}{l}\text { Requireme } \\
\text { nt } \\
\text { ID }\end{array}$ & $\begin{array}{c}\text { Referen } \\
\text { ce in } \\
\text { Base } \\
\text { Standar } \\
\text { d }\end{array}$ & $\begin{array}{l}\text { Requirement } \\
\text { Summary }\end{array}$ & $\begin{array}{l}\text { L } \\
\text { e } \\
\text { v } \\
\text { e } \\
\text { I }\end{array}$ & $\begin{array}{l}\mathrm{s} \\
\mathrm{t} \\
\mathrm{a} \\
\mathrm{t} \\
\mathrm{u} \\
\mathrm{s}\end{array}$ & $\begin{array}{l}\text { Assertion } \\
\text { ID }\end{array}$ & $\begin{array}{l}\text { Test } \\
\text { Assertion }\end{array}$ & $\begin{array}{l}\text { Test } \\
\text { Note }\end{array}$ & $\begin{array}{l}\text { Implemen } \\
\text { tation } \\
\text { Support }\end{array}$ & $\begin{array}{l}\text { Supporte } \\
\text { d Range }\end{array}$ & $\begin{array}{l}\text { Test } \\
\text { Result }\end{array}$ & $\begin{array}{l}\text { Applicab } \\
\text { ility }\end{array}$ \\
\hline \multicolumn{12}{|c|}{ 8.13: Record Type-13: Friction-ridge latent image record } \\
\hline \multirow{8}{*}{$\begin{array}{l}\text { Field: } \\
\text { Type13- } \\
\text { Subfield } \\
\text { Occurenece }\end{array}$} & \multirow[t]{8}{*}{ Table 66} & \multirow[t]{8}{*}{$\begin{array}{l}<\text { Table } 66 \text { specifies which fields contain } \\
\text { subfields as well as the number of } \\
\text { occurrences permitted.> }\end{array}$} & 1 & - & $\begin{array}{l}\text { Type13- } \\
\text { Subfields } \\
\text { Zero }\end{array}$ & $\begin{array}{l}\text { Count(Subfields in } 13 .[001 \text { to } 003,005 \text { to } 012 \text {, } \\
016,017,020,903,996,999]) \text { EQ } 0\end{array}$ & & & & & $\mathrm{~T}$ \\
\hline & & & 1 & M & $\begin{array}{l}\text { 13.004- } \\
\text { Subfields }\end{array}$ & Count(US_Subfields in 13.004) EQ 1 OR 2 & & & & & T \\
\hline & & & 1 & M & $\begin{array}{l}\text { 13.013- } \\
\text { Subfields }\end{array}$ & Count(US_Subfields in 13.013 ) MO [1 to 6] & & & & & T \\
\hline & & & 1 & D & $\begin{array}{l}\text { 13.014- } \\
\text { Subfields }\end{array}$ & $\begin{array}{l}\text { Count(RS_Subfields in 13.014) MO [1 to 9] } \\
\text { AND } \\
\text { ForEach(RS_Subfield in 13.014) } \\
\{ \\
\text { Count(US_Subfields in RS_Subfield) EQ } 2 \\
\}\end{array}$ & & & & & $\mathrm{T}$ \\
\hline & & & & D & $\begin{array}{l}\text { 13.015- } \\
\text { Subfields }\end{array}$ & $\begin{array}{l}\text { ¿See Requirement ID: “Field: PPC-Subfield } \\
\text { Occurrences"> }\end{array}$ & $\mathrm{t}-2$ & & & & \\
\hline & & & 1 & 0 & $\begin{array}{l}\text { 13.024- } \\
\text { Subfields }\end{array}$ & $\begin{array}{l}\text { Count(RS_Subfields in 13.024) MO [1 to 9] } \\
\text { AND } \\
\text { ForEach(RS_Subfield in 13.024) } \\
\{ \\
\text { Count(US_Subfields in RS_Subfield) EQ } 4 \\
\}\end{array}$ & & & & & T \\
\hline & & & 1 & 0 & $\begin{array}{l}13.902- \\
\text { Subfields }\end{array}$ & $\begin{array}{l}\text { Count (RS_Subfields in 13.902) GTE } 1 \\
\text { AND } \\
\text { ForEach(RS_Subfield in 13.902) } \\
\left\{\begin{array}{l}\text { Count(US_Subfields in RS_Subfield) EQ } 4 \\
\}\end{array}\right.\end{array}$ & & & & & $\mathrm{T}$ \\
\hline & & & 1 & 0 & 13.904- & Count(US_Subfields in 13.904) EQ 3 & & & & & $\mathrm{~T}$ \\
\hline
\end{tabular}



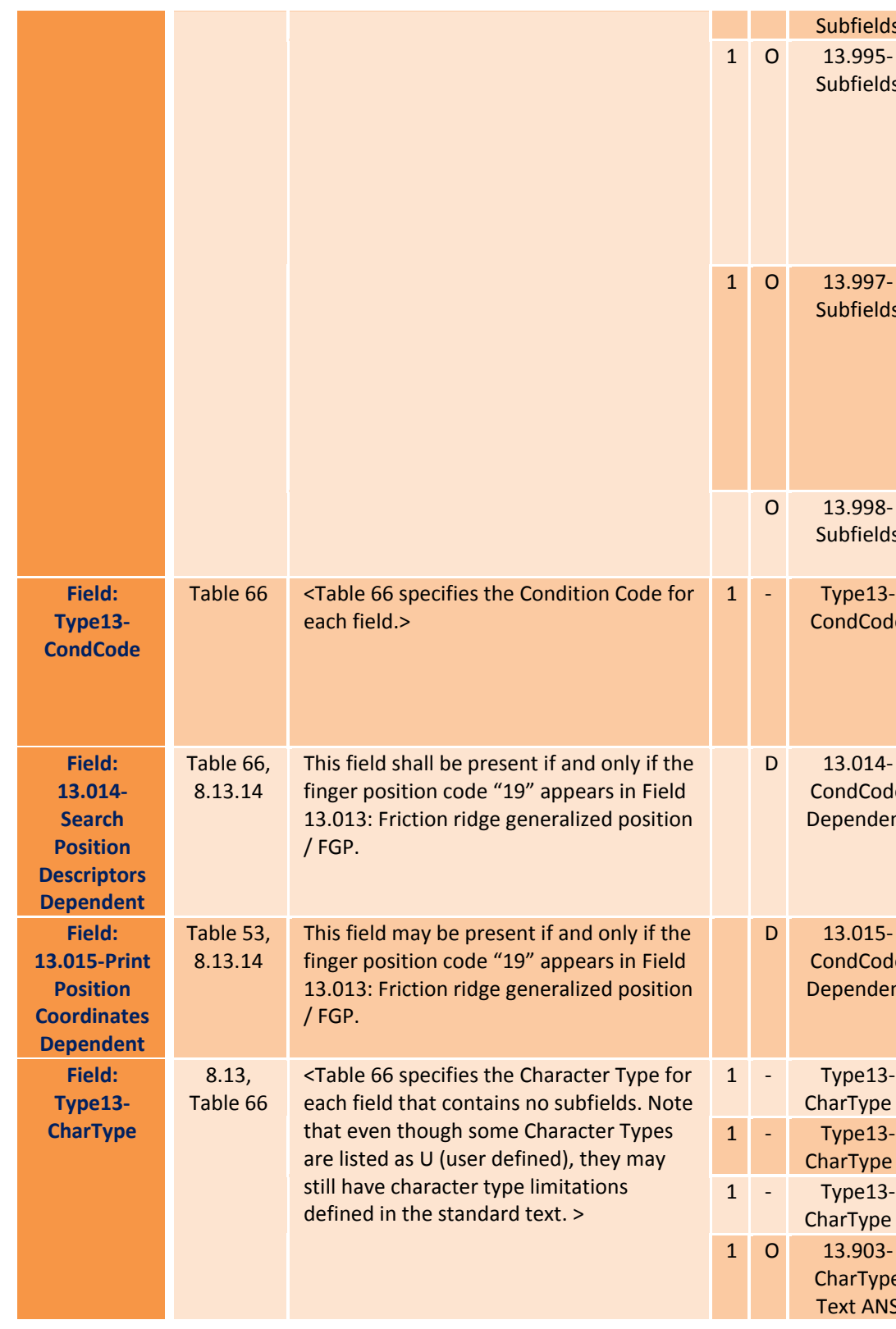

Count(RS_Subfields in 13.995) MO [1 to 255]

AND

ForEach(RS_Subfield in 13.995)

\{

Count(US_Subfields in RS_Subfield) EQ 1 OR 2

\begin{tabular}{l|l|r}
1 & 0 & $13.997-$
\end{tabular}

Subfields

AND

ForEach(RS_Subfield in 13.997)

\{

Count(US_Subfields in RS_Subfield) EQ 1 OR 2 \}

O $\quad 13.998-$

Subfields

<See Requirement ID: "Field: Geographic-

Conditional">

1 - Type13-

CondCode

AND

NOT Present(13.018, 13.019, 13.021 to 13.023

13.025 to $13.199,13.901,13.905$ to 13.994$)$

<See Requirement ID: "Field: SPD,PPC

D $\quad 13.014-$

CondCode

Dependent

Conditional">

D 13.015-

CondCode

<See Requirement ID: “Field: SPD,PPC

Conditional">

5]

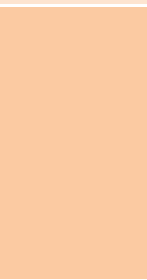

$\mathrm{t}-2$

Dependent

1 - Type13-

Byt

Bytes(13.[001,002,003, 005 to 010, 012, 016

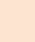

1 - Type13-

1 - CharType A

$\mathrm{MO}[0 \times 30$ to $0 \times 39]$

are listed as U (user defined), they may

defined in the standard text. >

CharType U

Bytes(13.011) MO [0x41 to $0 \times 5 \mathrm{~A}, 0 \times 61$ to $0 \times 7 \mathrm{~A}]$

1 O $13.903-\quad$ Bytes(10.903) MO [0x20, 0x7E]

\begin{tabular}{|l|l|l|l|l|}
\hline & CharType \\
Text ANS
\end{tabular}

Present(Bytes(13.020) 


\begin{tabular}{|c|c|c|c|c|c|c|c|}
\hline & & & 1 & 0 & $\begin{array}{l}\text { 13.996- } \\
\text { CharType H }\end{array}$ & $\begin{array}{l}\text { Bytes(10.996) MO [0x30 to } 0 \times 39,0 \times 41 \text { to } 0 \times 46 \text {, } \\
0 \times 61 \text { to } 0 \times 66]\end{array}$ & B \\
\hline \multirow{8}{*}{$\begin{array}{c}\text { Field: } \\
\text { Type13- } \\
\text { Subfield } \\
\text { CharType }\end{array}$} & \multirow[t]{8}{*}{$\begin{array}{l}8.13 \\
\text { Table } 66\end{array}$} & \multirow[t]{8}{*}{$\begin{array}{l}<\text { Table } 66 \text { specifies the Character Type for } \\
\text { each subfield.> }\end{array}$} & 1 & M & $\begin{array}{c}\text { 13.004- } \\
\text { Subfield } \\
\text { CharType U }\end{array}$ & Present( Bytes( US_Subfields:1,2 in 13.004 ) & $\mathrm{B}^{*}$ \\
\hline & & & 1 & M & $\begin{array}{c}13.013- \\
\text { Subfield } \\
\text { CharType N }\end{array}$ & $\begin{array}{l}\text { Bytes(All(US_Subfields in 13.013)) MO [0x30 to } \\
\text { 0x39] }\end{array}$ & $\mathrm{B}^{*}$ \\
\hline & & & 1 & D & $\begin{array}{c}\text { 13.014- } \\
\text { Subfield } \\
\text { CharType } \\
\text { AN }\end{array}$ & 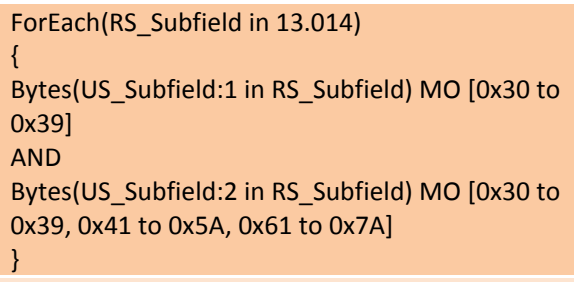 & $\mathrm{B}^{*}$ \\
\hline & & & 1 & $\mathrm{D}$ & $\begin{array}{c}13.015- \\
\text { Subfield } \\
\text { CharType } \\
\text { AN }\end{array}$ & 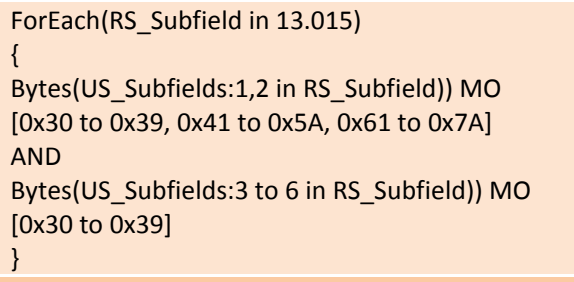 & $\mathrm{B}^{*}$ \\
\hline & & & 1 & 0 & $\begin{array}{c}\text { 13.024- } \\
\text { Subfield } \\
\text { CharType } \\
\text { HN }\end{array}$ & $\begin{array}{l}\text { ForEach(RS_Subfield in } 13.024 \text { ) } \\
\{ \\
\text { Bytes(US_Subfields:1,2,4 in RS_Subfield)) MO } \\
\text { [0x30 to } 0 \times 39] \\
\text { AND } \\
\text { Bytes(US_Subfields: } 3 \text { in RS_Subfield)) MO [0×30 } \\
\text { to } 0 \times 39,0 \times 41 \text { to } 0 \times 46,0 \times 61 \text { to } 0 \times 66] \\
\text { \} }\end{array}$ & $\mathrm{B}^{*}$ \\
\hline & & & 1 & 0 & $\begin{array}{c}\text { 13.902- } \\
\text { Subfield } \\
\text { CharType } \\
\text { ANU }\end{array}$ & $\begin{array}{l}\text { ForEach(RS_Subfield in 13.902) } \\
\{ \\
\text { Present(Bytes(US_Subfields: } 2 \text { to } 4 \text { in } \\
\text { RS_Subfield)) } \\
\text { AND } \\
\text { Bytes(US_Subfield:1 in RS_Subfield) MO [0×30 to } \\
\text { 0x39, 0x5A] } \\
\}\end{array}$ & $\mathrm{B}^{*}$ \\
\hline & & & 1 & 0 & $\begin{array}{c}\text { 13.904- } \\
\text { Subfield } \\
\text { CharType U }\end{array}$ & Present(Bytes(All(US_Subfields in 13.904))) & $\mathrm{B}^{*}$ \\
\hline & & & 1 & 0 & $\begin{array}{c}13.995- \\
\text { Subfield } \\
\text { CharType N }\end{array}$ & $\begin{array}{l}\text { Bytes(All(US_Subfields:1,2 in 13.995)) MO [0x30 } \\
\text { to 0x39] }\end{array}$ & $\mathrm{B}^{*}$ \\
\hline
\end{tabular}



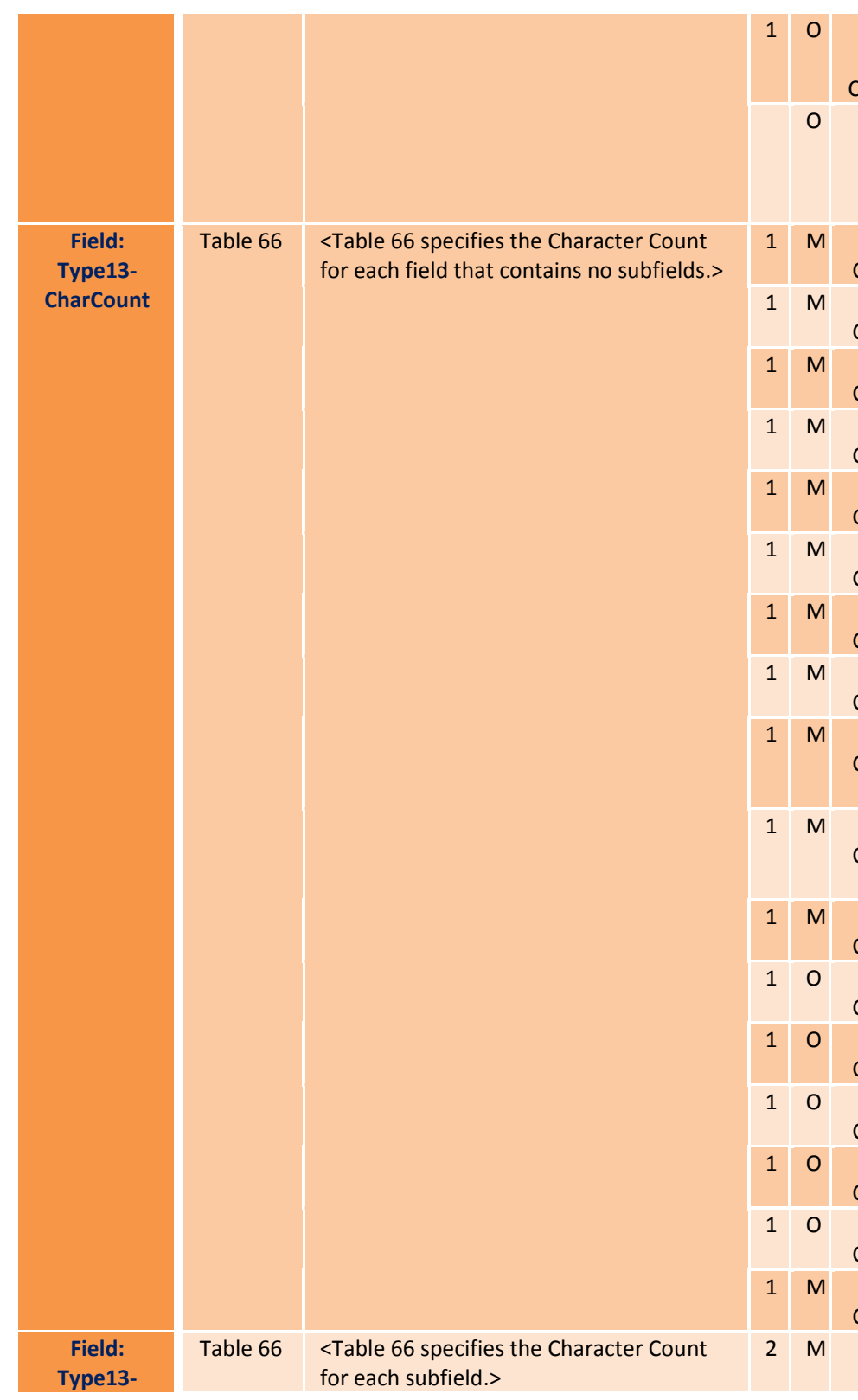

13.997-
Subfield CharType N

13.998Subfield CharType ANSU

1 M $\begin{gathered}13.001- \\ \text { CharCount }\end{gathered}$

1 M $\begin{gathered}13.002- \\ \text { CharCount }\end{gathered}$

1 M 13.003-

CharCount

1 M $\begin{gathered}13.005- \\ \text { CharCount }\end{gathered}$

1 M 13.006-

CharCount

1 M 13.007-

1 M 13.008-

CharCount

1 M 13.009-

1 M 13.010 CharCount

1 M 13.011CharCount

1 M 13.012-

10 13.016CharCount

10 13.017-

10 13.020CharCount

10 13.903-

CharCount

10 13.996-

1 M 13.999-

CharCount

2 M 13.004-

(All(US Subfields:1,2 in 13.997)) MO [0×30 to $0 \times 39$

<See Requirement ID: "Field: Geographic">

DataLength(13.001) GTE 1

Datalength(13.002) EQ 1 OR 2

DataLength(13.003) EQ 1 OR 2

DataLength(13.005) EQ 8

DataLength(13.006) MO [2 to 5]

DataLength(13.007) MO [2 to 5]

DataLength(13.008) EQ 1

DataLength(13.009) MO [1 to 5]

DataLength(13.010) MO [1 to 5]

DataLength(13.011) MO [3 to 5]

DataLength(13.012) EQ 1 OR 2

Datalength(13.016) MO [1 to 4]

DataLength(13.017) MO [1 to 4]

Datalength(13.020) MO [1 to 126]

DataLength(13.903) MO [13 to 16$]$

DataLength(13.995) EQ 64

DataLength(13.999) GTE 1

Length(All(US_Subfields in 13.004)) GTE 1
$\mathrm{B}^{*}$

$\mathrm{t}-2$

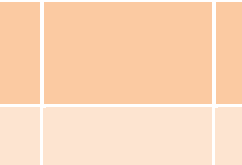

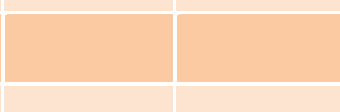

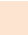

B

B

B




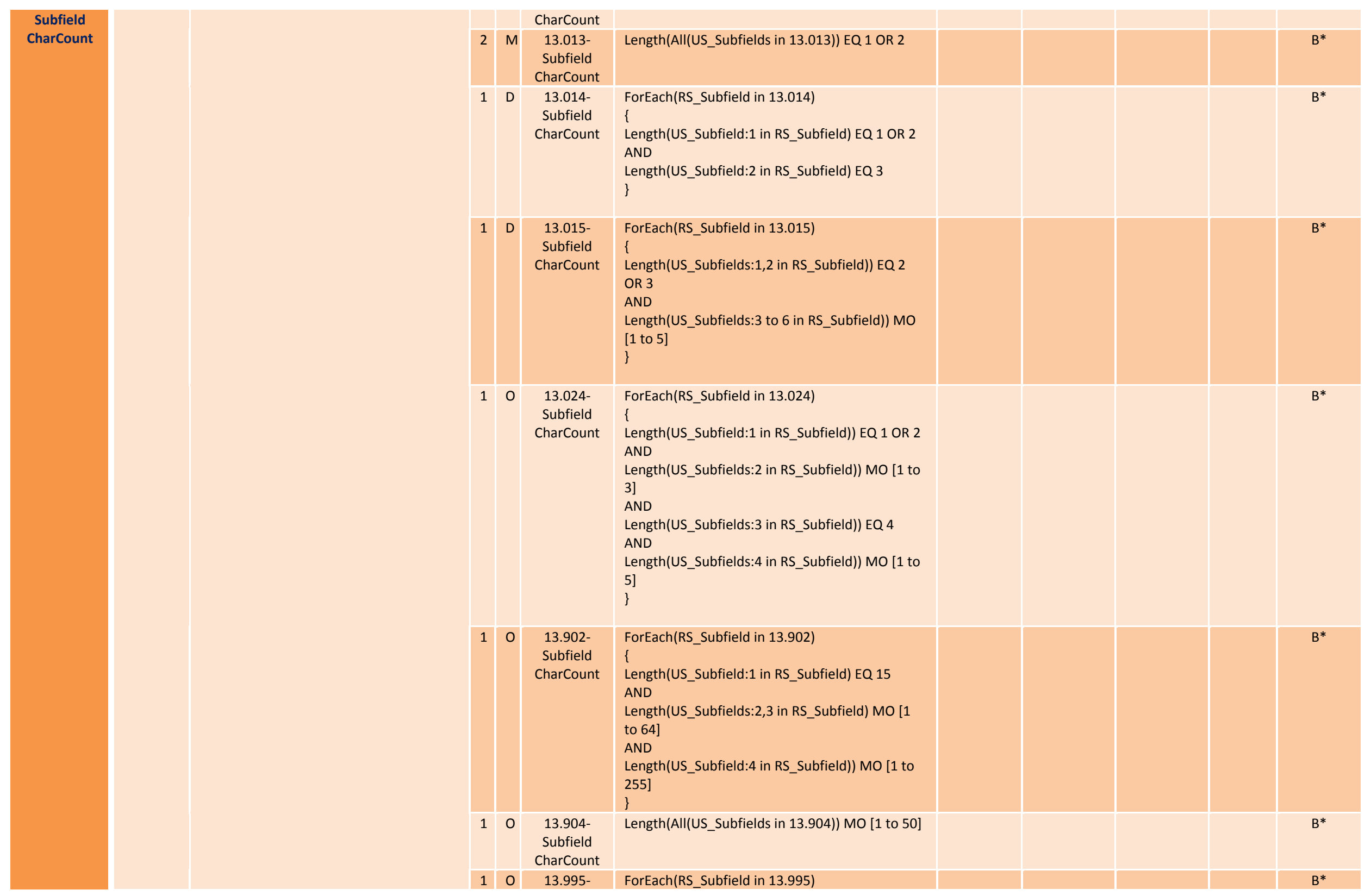




\begin{tabular}{|c|c|c|c|c|c|c|c|c|}
\hline & & & & & $\begin{array}{l}\text { Subfield } \\
\text { CharCount }\end{array}$ & $\begin{array}{l}\text { \{ } \\
\text { Length(US_Subfield: } 1 \text { in RS_Subfield) MO [1 to } 3] \\
\text { AND } \\
\text { Length(US_Subfield: } 2 \text { in RS_Subfield) EQ } 1 \text { OR } 2 \\
\}\end{array}$ & & \\
\hline & & & 1 & 0 & $\begin{array}{l}\text { 13.997- } \\
\text { Subfield } \\
\text { CharCount }\end{array}$ & $\begin{array}{l}\text { ForEach(RS_Subfield in 13.997) } \\
\{ \\
\text { Length(US_Subfield:2 in RS_Subfield) MO [1 to 3] } \\
\text { AND } \\
\text { Length(US_Subfield:2 in RS_Subfield) EQ } 1 \text { OR } 2 \\
\}\end{array}$ & & $\mathrm{B}^{*}$ \\
\hline & & & & 0 & $\begin{array}{l}\text { 13.998- } \\
\text { Subfield } \\
\text { CharCount }\end{array}$ & <See Requirement ID: "Field: Geographic"> & $t-2$ & \\
\hline \multirow[t]{3}{*}{$\begin{array}{l}\text { Field: } \\
\text { Type13-Field } \\
\text { Occurrence }\end{array}$} & \multirow[t]{3}{*}{ Table 66} & \multirow[t]{3}{*}{$\begin{array}{l}<\text { Table } 66 \text { specifies the Field Occurrence } \\
\text { for each field.> }\end{array}$} & 1 & - & $\begin{array}{l}\text { Type13- } \\
\text { Occurrence } \\
\text { Zero }\end{array}$ & $\begin{array}{l}\text { Count(13.[016, } 017,021 \text { to } 023,025 \text { to } \\
199,901,905 \text { to } 994]) \text { EQ } 0\end{array}$ & & B \\
\hline & & & 1 & M & $\begin{array}{l}\text { Type13- } \\
\text { Occurrence } \\
\text { One }\end{array}$ & Count(13.[001 to 013, 999]) EQ 1 & & B \\
\hline & & & 1 & - & $\begin{array}{l}\text { Type13- } \\
\text { Occurrence } \\
\text { One or } \\
\text { Fewer }\end{array}$ & $\begin{array}{l}\text { Count(13. [ } 014 \text { to } 017,020,024,902 \text { to } 904,995 \\
\text { to } 998) \text { LTE } 1\end{array}$ & & B \\
\hline \multirow{2}{*}{$\begin{array}{l}\text { Field: } \\
\text { 13.001- } \\
\text { Record } \\
\text { Header } \\
\text { Value }\end{array}$} & $\begin{array}{c}\text { 8.13.1, } \\
\text { Table 66, } \\
7.1\end{array}$ & $\begin{array}{l}\text { Field } 13.001 \text { Record header. In Traditional } \\
\text { encoding, this field contains the record } \\
\text { length in bytes (including all information } \\
\text { separators) }\end{array}$ & & M & $\begin{array}{l}13.001- \\
\text { Record } \\
\text { Header }\end{array}$ & $\begin{array}{l}<\text { See Requirement ID “Field: xx.001-Record } \\
\text { Header"> }\end{array}$ & $t-2$ & \\
\hline & $\begin{array}{l}\text { 8.13.1 } \\
\text { C.10.11 }\end{array}$ & $\begin{array}{l}\text { The XML name for the Type- } 13 \text { record is } \\
<\text { itl:PackageLatentImageRecord>, and its } \\
<\text { biom:RecordCategoryCode> element } \\
\text { shall have a value of " } 13 \text { ". }\end{array}$ & 1 & M & $\begin{array}{l}\text { NIEM- } \\
13.001- \\
\text { Record } \\
\text { Header }\end{array}$ & $\begin{array}{l}\text { ForEach(itl:PackageLatentImageRecord) } \\
\{ \\
\{\text { XEIm(biom:RecordCategoryCode)\} EQ ASCII(13) } \\
\}\end{array}$ & & $\mathrm{x}$ \\
\hline $\begin{array}{l}\text { Field: } \\
\text { 13.002- } \\
\text { Information } \\
\text { Designation } \\
\text { Character } \\
\text { Value }\end{array}$ & $\begin{array}{c}\text { 8.13.2, } \\
\text { Table 66, } \\
7.3 .1\end{array}$ & $\begin{array}{l}\text { This mandatory field shall be the IDC of } \\
\text { this Type- } 13 \text { record as found in the } \\
\text { information item IDC of Field } 1.003 \\
\text { Transaction content/CNT. }\end{array}$ & & M & 13.002-IDC & $\begin{array}{l}\text { <See Requirement IDs "Field: } \\
\text { xx.002-IDC and "Field: } 1.003-\text { Transaction } \\
\text { Content Subfield } 2 \text { IDC Matches" }>\end{array}$ & $\mathrm{t}-2$ & \\
\hline $\begin{array}{l}\text { Field: } \\
\text { 13.003- } \\
\text { Impression } \\
\text { Type } \\
\text { Value }\end{array}$ & $\begin{array}{c}\text { 8.13.3, } \\
\text { Table 66, } \\
\text { 7.7.4.1 }\end{array}$ & $\begin{array}{l}\text { This mandatory field shall indicate the } \\
\text { manner by which the latent print was } \\
\text { obtained. } \\
\text { See Section } 7.7 .4 .1 \text { for details. Valid } \\
\text { values are } 4 \text { through } 7,12 \text { through } 15 \text { and } \\
32 \text { through } 39 \text {. }\end{array}$ & 1 & M & 13.003-IMP & $\{13.003\} \mathrm{MO}[4$ to 7,12 to 15,32 to 39$]$ & & B \\
\hline $\begin{array}{l}\text { Field: } \\
13.004-\end{array}$ & $\begin{array}{l}\text { 8.13.4 } \\
7.6\end{array}$ & $\begin{array}{l}\text { This is a mandatory field. See Section } 7.6 \\
\text { for details. }\end{array}$ & & M & $\begin{array}{l}\text { 13.004- } \\
\text { ORG }\end{array}$ & <See Requirement ID “Field: Agency Codes" > & $\mathrm{t}-2$ & \\
\hline
\end{tabular}




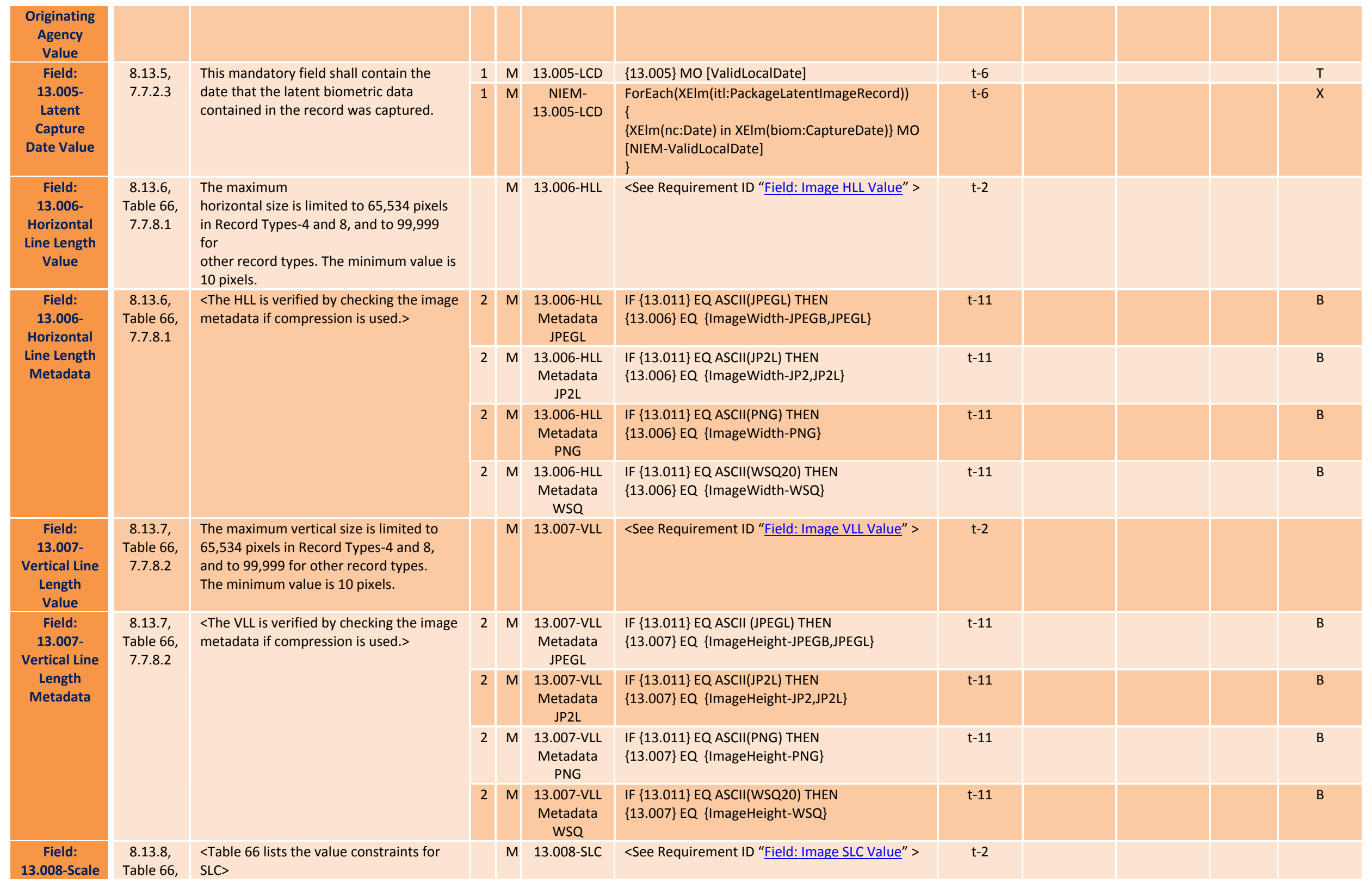




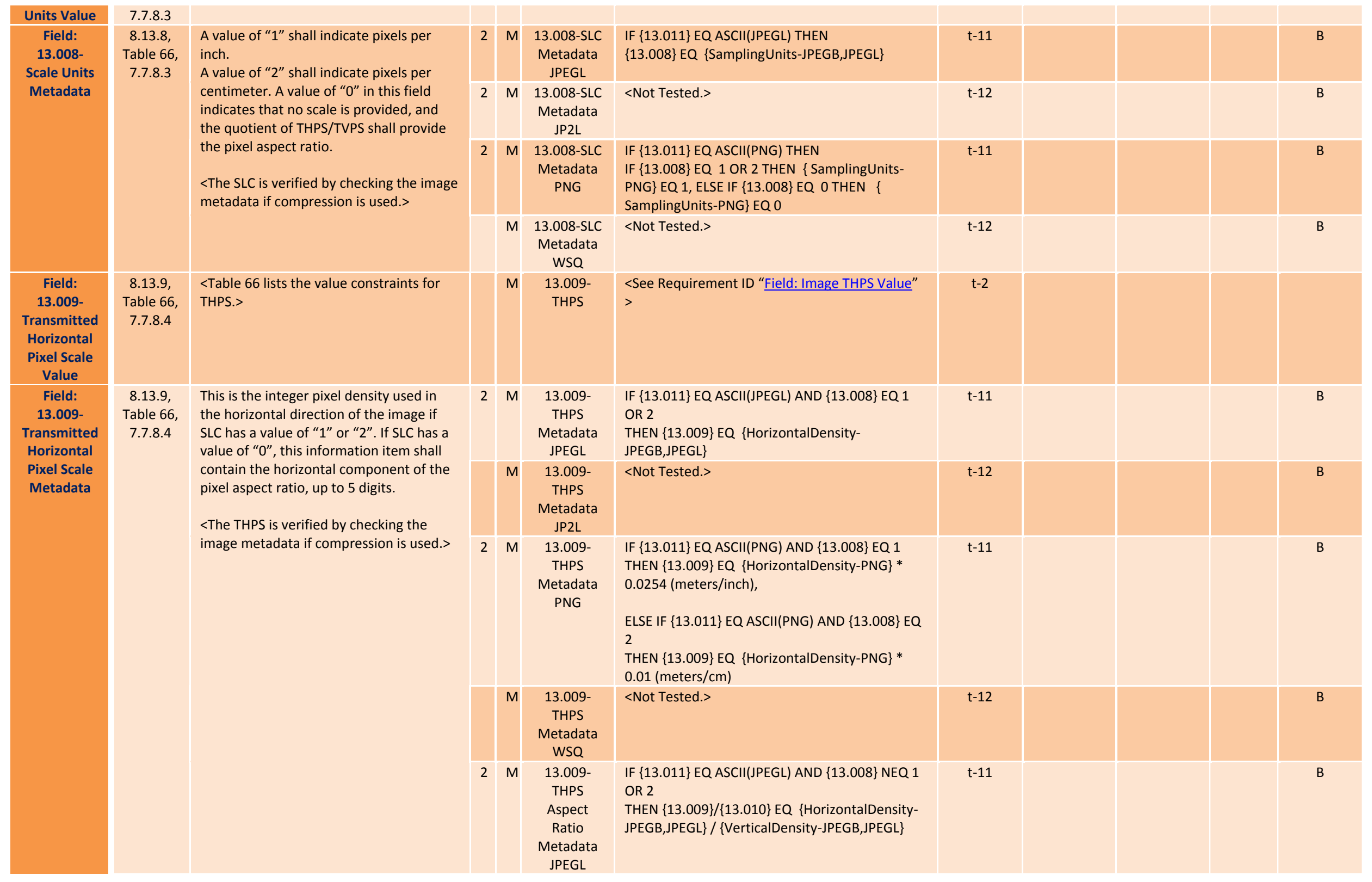




\begin{tabular}{|c|c|c|c|c|c|c|c|c|}
\hline & & & & M & $\begin{array}{l}\text { 13.009- } \\
\text { THPS } \\
\text { Aspect } \\
\text { Ratio } \\
\text { Metadata } \\
\text { JP2L }\end{array}$ & $<$ Not Tested. $>$ & $\mathrm{t}-12$ & B \\
\hline & & & 2 & $M$ & $\begin{array}{l}\text { 13.009- } \\
\text { THPS } \\
\text { Aspect } \\
\text { Ratio } \\
\text { Metadata } \\
\text { PNG }\end{array}$ & $\begin{array}{l}\text { IF }\{13.011\} \text { EQ ASCII(PNG) AND }\{13.008\} \text { NEQ } 1 \\
\text { OR } 2 \\
\text { THEN }\{13.009\} /\{13.010\} \text { EQ }\{\text { HorizontalDensity- } \\
\text { PNG } /\{\text { VerticalDensity-PNG }\}\end{array}$ & $\mathrm{t}-11$ & B \\
\hline & & & & M & $\begin{array}{l}\text { 13.009- } \\
\text { THPS } \\
\text { Aspect } \\
\text { Ratio } \\
\text { Metadata } \\
\text { WSQ }\end{array}$ & $<$ Not Tested. $>$ & $t-12$ & B \\
\hline $\begin{array}{l}\text { Field: } \\
\text { 13.010- } \\
\text { Transmitted } \\
\text { Vertical } \\
\text { Pixel Scale } \\
\text { Value }\end{array}$ & $\begin{array}{l}\text { 8.13.10, } \\
\text { Table 66, } \\
\text { 7.7.8.5 }\end{array}$ & $\begin{array}{l}<\text { Table } 66 \text { lists the value constraints for } \\
\text { TVPS.> }\end{array}$ & & $M$ & $\begin{array}{l}\text { 13.010- } \\
\text { TVPS }\end{array}$ & $\begin{array}{l}<\text { See Requirement ID “Field: Image TVPS Value" } \\
>\end{array}$ & $t-2$ & \\
\hline \multirow{5}{*}{$\begin{array}{c}\text { Field: } \\
\text { 13.010- } \\
\text { Transmitted } \\
\text { Vertical } \\
\text { Pixel Scale } \\
\text { Metadata }\end{array}$} & \multirow[t]{5}{*}{$\begin{array}{l}\text { 8.13.10, } \\
\text { Table } 66, \\
7.7 .8 .5\end{array}$} & \multirow{5}{*}{$\begin{array}{l}\text { This is the integer pixel density used in } \\
\text { the Vertical direction of the image if SLC } \\
\text { has a value of " } 1 \text { " or " } 2 \text { ". If SLC has a } \\
\text { value of " } 0 \text { ", this information item shall } \\
\text { contain the Vertical component of the } \\
\text { pixel aspect ratio, up to } 5 \text { digits. } \\
\text { <The TVPS is verified by checking the } \\
\text { image metadata if compression is used.> }\end{array}$} & 2 & M & $\begin{array}{l}\text { 13.010- } \\
\text { TVPS } \\
\text { Metadata } \\
\text { JPEGL }\end{array}$ & $\begin{array}{l}\text { IF }\{13.011\} \text { EQ ASCII(JPEGL) AND }\{13.008\} \text { EQ } 1 \\
\text { OR } 2 \\
\text { THEN }\{13.010\} \text { EQ }\{\text { VerticalDensity-JPEGB,JPEGL }\}\end{array}$ & $\mathrm{t}-11$ & B \\
\hline & & & & $M$ & $\begin{array}{l}\text { 13.010- } \\
\text { TVPS } \\
\text { Metadata } \\
\text { JP2L }\end{array}$ & $<$ Not Tested. $>$ & $\mathrm{t}-12$ & B \\
\hline & & & 2 & M & $\begin{array}{l}\text { 13.010- } \\
\text { TVPS } \\
\text { Metadata } \\
\text { PNG }\end{array}$ & $\begin{array}{l}\text { IF }\{13.011\} \text { EQ ASCII(PNG) AND }\{13.008\} \text { EQ } 1 \\
\text { THEN }\{13.010\} \text { EQ }\{\text { VerticalDensity-PNG }\} \text { * } \\
0.0254 \text { (meters/inch), } \\
\text { ELSE IF }\{13.011\} \text { EQ ASCII(PNG) AND }\{13.008\} \text { EQ } \\
2 \\
\text { THEN }\{13.010\} \text { EQ }\{\text { VerticalDensity-PNG }\} * 0.01 \\
\text { (meters/cm) }\end{array}$ & $\mathrm{t}-11$ & B \\
\hline & & & & $M$ & $\begin{array}{l}\text { 13.010- } \\
\text { TVPS } \\
\text { Metadata } \\
\text { WSQ }\end{array}$ & $<$ Not Tested. $>$ & $\mathrm{t}-12$ & B \\
\hline & & & 2 & M & $\begin{array}{l}\text { 13.010- } \\
\text { TVPS }\end{array}$ & $\begin{array}{l}\text { IF }\{13.011\} \text { EQ ASCII(JPEGL) AND }\{13.008\} \text { NEQ } 1 \\
\text { OR } 2\end{array}$ & $\mathrm{t}-11$ & B \\
\hline
\end{tabular}




\begin{tabular}{|c|c|c|c|c|c|c|c|c|}
\hline & & & & & $\begin{array}{l}\text { Aspect } \\
\text { Ratio } \\
\text { Metadata } \\
\text { JPEGL }\end{array}$ & $\begin{array}{l}\text { THEN }\{13.009\} /\{13.010\} \text { EQ }\{\text { HorizontalDensity- } \\
\text { JPEGB,JPEGL } /\{\text { VerticalDensity-JPEGB,JPEGL\} }\end{array}$ & & \\
\hline & & & & M & $\begin{array}{l}\text { 13.010- } \\
\text { TVPS } \\
\text { Aspect } \\
\text { Ratio } \\
\text { Metadata } \\
\text { JP2L }\end{array}$ & $<$ Not Tested. $>$ & $\mathrm{t}-12$ & B \\
\hline & & & 2 & M & $\begin{array}{c}\text { 13.010- } \\
\text { TVPS } \\
\text { Aspect } \\
\text { Ratio } \\
\text { Metadata } \\
\text { PNG }\end{array}$ & $\begin{array}{l}\text { IF }\{13.011\} \text { EQ ASCII(PNG) AND }\{13.008\} \text { NEQ } 1 \\
\text { OR } 2 \\
\text { THEN }\{13.009\} /\{13.010\} \text { EQ }\{\text { HorizontalDensity - } \\
\text { PNG } /\{\text { VerticalDensity-PNG }\}\end{array}$ & $\mathrm{t}-11$ & B \\
\hline & & & & M & $\begin{array}{l}\text { 13.010- } \\
\text { TVPS } \\
\text { Aspect } \\
\text { Ratio } \\
\text { Metadata } \\
\text { WSQ }\end{array}$ & $<$ Not Tested. $>$ & $\mathrm{t}-12$ & B \\
\hline $\begin{array}{c}\text { Field: } \\
\text { 13.011- } \\
\text { Compressio } \\
\text { n Algorithm } \\
\text { Value }\end{array}$ & $\begin{array}{l}\text { 8.13.11, } \\
\text { Table 66, } \\
\text { 7.7.9.1, } \\
\text { 5.3.13 }\end{array}$ & $\begin{array}{l}\text { For each of these fields, the entry } \\
\text { corresponds to the appropriate Label } \\
\text { entry in Table 12: Field 13.011: } \\
\text { Compression algorithm / CGA. } \\
\text { The variable-resolution for latent image } \\
\text { data contained in the Type-13 record shall } \\
\text { be uncompressed or may be the output } \\
\text { from a lossless compression algorithm. }\end{array}$ & 1 & M & 13.011-CGA & $\begin{array}{l}\{13.011\} \mathrm{MO} \text { [ASCII(NONE, JPEGL, JP2L, PNG, } \\
\text { WSQ)] }\end{array}$ & $\mathrm{t}-98$ & B \\
\hline \multirow{4}{*}{$\begin{array}{c}\text { Field: } \\
\text { 13.011- } \\
\text { Compressio } \\
\text { n Algorithm } \\
\text { Metadata }\end{array}$} & \multirow[t]{4}{*}{$\begin{array}{l}8.13 .11 \\
\text { Table } 66\end{array}$} & \multirow[t]{4}{*}{$\begin{array}{l}\text { <The CGA is verified by checking the } \\
\text { image metadata for the compression type } \\
\text { signature if compression is used.> }\end{array}$} & 2 & M & $\begin{array}{l}13.011- \\
\text { CGAMetad } \\
\text { ata JPEGL }\end{array}$ & $\begin{array}{l}\text { IF }\{13.011\} \text { EQ ASCII(JPEGL) THEN } \\
\text { Present(SOI -JPEG,JPEGL) }\end{array}$ & $\mathrm{t}-11$ & B \\
\hline & & & 2 & M & $\begin{array}{l}\text { 13.011-CGA } \\
\text { Metadata } \\
\text { JP2L }\end{array}$ & $\begin{array}{l}\text { IF }\{13.011\} \text { EQ ASCII(JP2L) THEN } \\
\text { Present(SigBox) }\end{array}$ & $\mathrm{t}-11$ & B \\
\hline & & & 2 & M & $\begin{array}{l}\text { 13.011-CGA } \\
\text { Metadata } \\
\text { PNG }\end{array}$ & $\begin{array}{l}\text { IF }\{13.011\} \text { EQ ASCII(PNG) THEN } \\
\text { Present(PNGSig) }\end{array}$ & $\mathrm{t}-11$ & B \\
\hline & & & 2 & M & $\begin{array}{l}\text { 13.011-CGA } \\
\text { Metadata } \\
\text { WSQ }\end{array}$ & $\begin{array}{l}\text { IF }\{13.011\} \text { EQ ASCII(WSQ20) THEN } \\
\text { Present(SOI-WSQ) }\end{array}$ & $\mathrm{t}-11$ & B \\
\hline $\begin{array}{l}\text { Field: } \\
\text { 13.012-Bits } \\
\text { Per Pixel }\end{array}$ & $\begin{array}{l}\text { 8.13.12, } \\
\text { Table 66, } \\
\text { 7.7.8.6 }\end{array}$ & $\begin{array}{l}\text { This field shall contain an entry of " } 8 \text { " for } \\
\text { normal grayscale values of " } 0 \text { " to " } 255 \text { ". } \\
\text { Any entry in this field greater than " } 8 \text { " }\end{array}$ & & M & 13.012-BPX & <See Requirement ID “Field: Image BPX Value” > & $t-2$ & \\
\hline
\end{tabular}




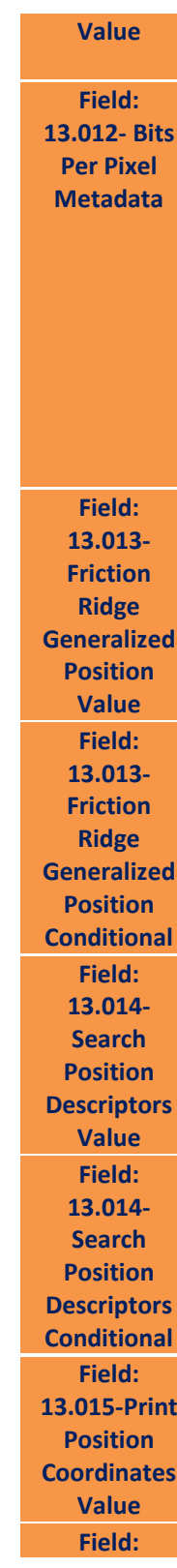

shall represent a grayscale pixel with

increased proportion.

8.13.12, <The BPX is verified by checking the

Table 66 image metadata for the compression type

signature if compression is used.>

2 M 13.012-BPX

Metadata

JPEGL

2 M $\begin{gathered}\text { 13.012-BPX } \\ \text { Metadata }\end{gathered}$

JP2L

2 M 13.012-BPX

Metadata

PNG

M 13.012-BPX

Metadata

WSQ

8.13.13, See Section 7.7.4.2 and Table 6 for

1 M 13.013-FGP

details.

Value

$\{13.012\}$ EQ $\{B P X-J P E G, J P E G L\}$

$\{13.012\}$ EQ \{BPX-JP2,JP2L\}

S

13.012\} $E Q\{B P X-P N G\}$

$\mathrm{t}-11$

(1)

$<$ Not Tested. $>$

$t-11$

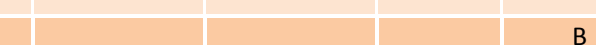

$\{13.013\} \mathrm{MO}[0$ to 38,40 to 50,60 to 79,81 to

84]

Table 6

(n)

8.13.13, If code 19 is used, fields 13.014 and

13.015 shall be used.

M 13.013-FGP

Conditional

Conditiona"> ID: "Field: SPD,PPC

Conditional">

$\mathrm{t}-12$

B

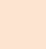

\begin{tabular}{|l|l|l|l|l|l|}
\hline & B \\
\hline & \\
\hline
\end{tabular}

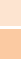

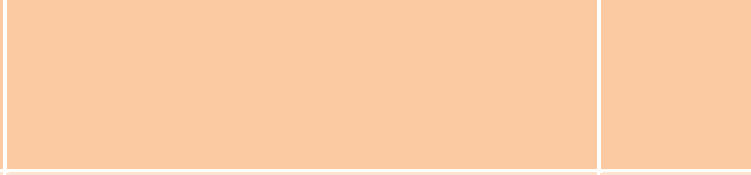

$\mathrm{t}-2$

8.13.14,

...described in Section 7.7.4.3

Table 66,

7.7.4.3

8.13.14,

Table 66

This field shall be present if and only if the

finger position code "19" appears in Field

13.013: Friction ridge generalized position

/ FGP.

D $13.014-S P D$ Conditional

Conditional">

D $13.014-S P D$

Value

<See Requirement ID: “Field: SPD,PPD Values”>
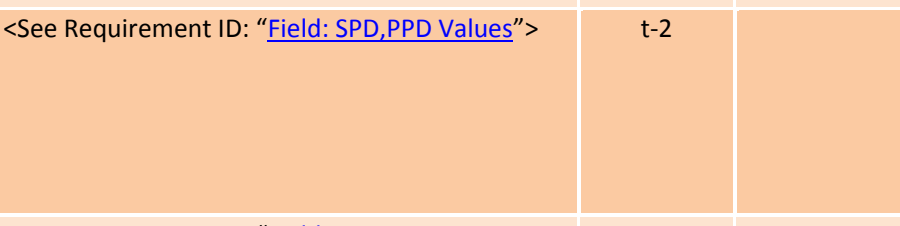

$\mathrm{t}-2$

8.13.15, $\quad$ See section 7.7.4.4

Table 66,

7.7.4.4

8.13.15, This field may be present if and only if the

D $13.015-P P C$

<See Requirement ID: “Field: SPD,PPC

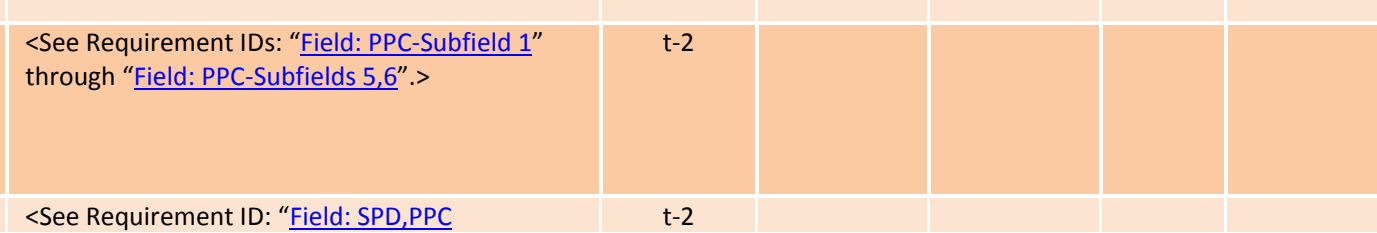




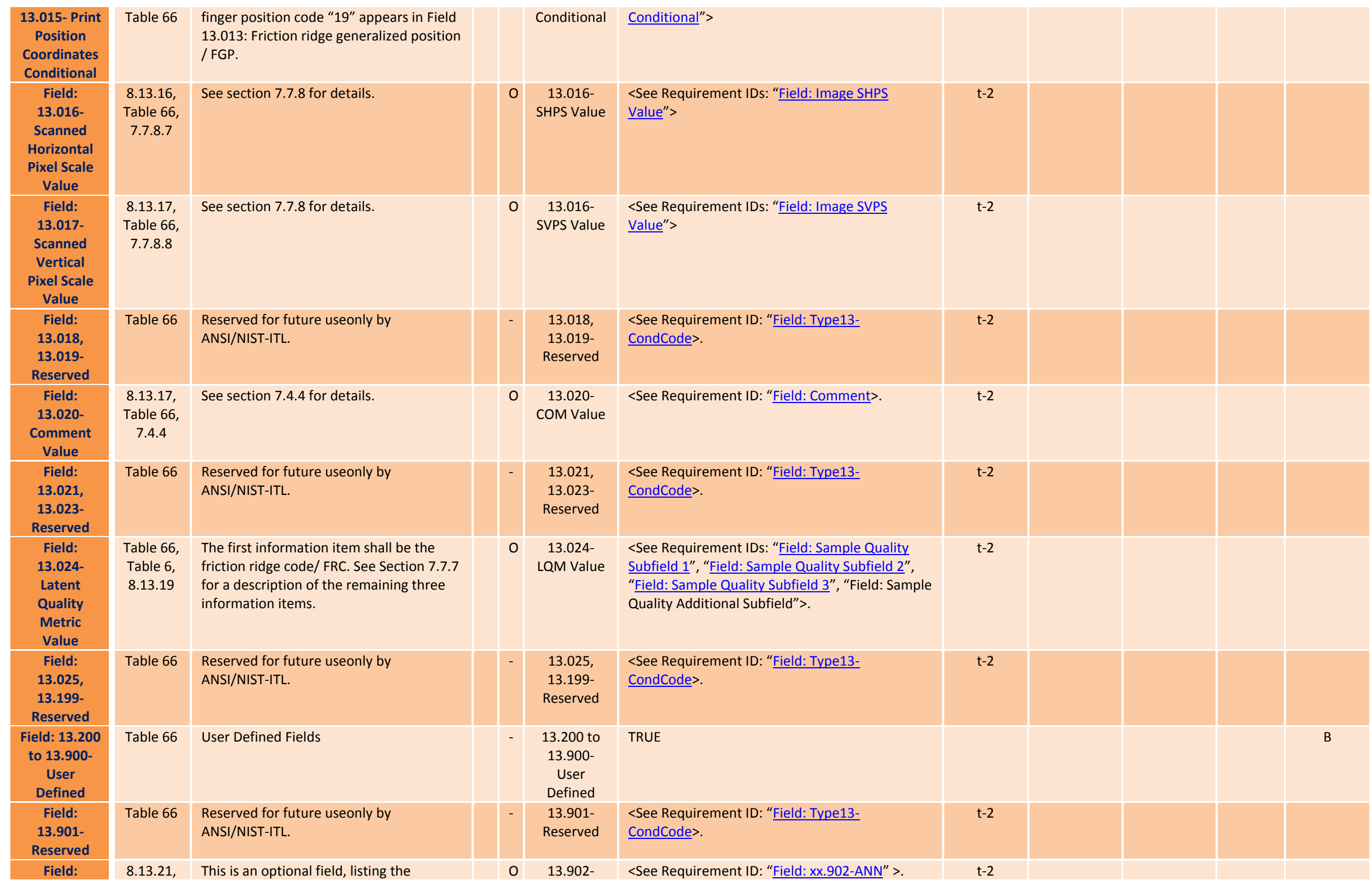




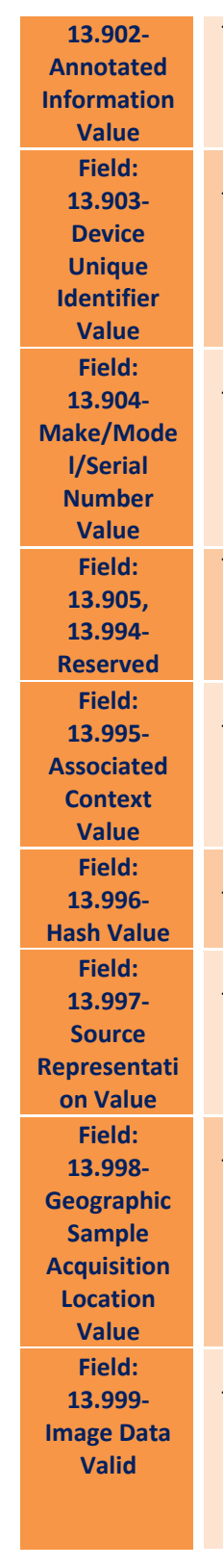

Table 66 operations performed on the original

source in order to prepare it for inclusion

in a biometric record type. See Section

7.4.1.

8.13.22, This is an optional field. See Section

Table 66 7.7.1.1.

8.13.23, This is an optional field. See Section

Table 66 7.7.1.2.

Table 66

Reserved for future useonly by

ANSI/NIST-ITL.

8.13.24,

Table 66

See Section 7.3.3

8.13.25,

Table 66

8.13.26,

Table 66

8.13.27,

Table 66

See Section 7.7.3

O $13.998-$

GEO Value

(1)

This is a mandatory field contains the

image.

$<$ The image metadata is checked for validity.>

ANN-Value

O 13.903-DUI Value

O $\quad 13.904-$ MMS Value

Value

O $13.997-S O R$

Value

Uncompres

sed Valid
<See Requirement ID: "Field: Make Model" >

$\mathrm{t}-2$

<See Requirement ID: "Field: Type13-

CondCode>.

<See Requirement IDs: "Field: xx.995-ASC" and

"Field: xx.995-ASC-ACN" and

“Field: xx.995-ASC-ASP">

0 13.996-HAS <See Requirement ID: "Field: HAS">

<See Requirement IDs: "Field: xx.997-SOR" and

"Field: xx.997-SOR-SRN" and

“Field: xx.997-SOR-RSP">

<See Requirement IDs: "Field: Geographic",

"Field: Geographic-Conditional", "Field:

Geographic-Subfield 1" through "Field:

Geographic-Values-SubField 15" $>$.

2 M 13.999- IF $\{13.011\}$ EQ ASCII(NONE) THEN

DATA Length(13.999) EQ 13.006 $\} *\{13.007\}$

2 M 13.999- IF $\{13.011\}$ EQ ASCII(JPEGL) THEN

DATA Present(JFIF, 

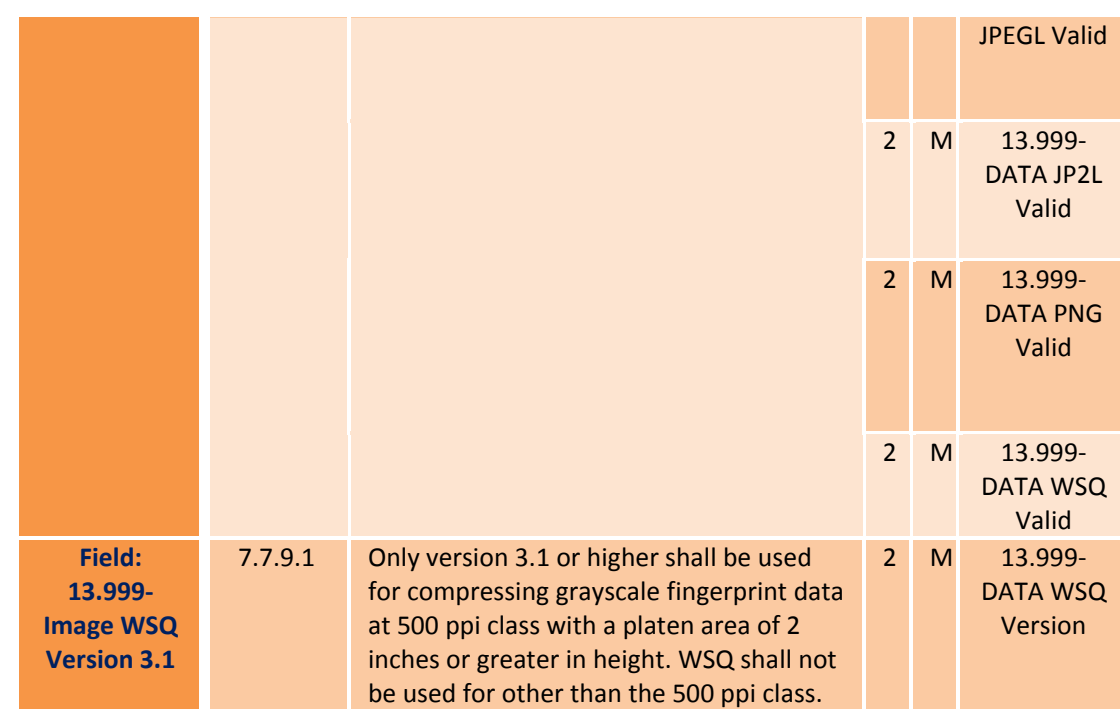

SOI-JPEGB,JPEGL,

SOF-JPEGB,JPEGL,

EOI-JPEG, JPEGL)

IF $\{13.011\}$ EQ ASCII(JP2L) THEN

DATA JP2

Present(SigBox

HeadBox
2 M 13.999-
DATA PNG
Valid

IF $\{13.011\}$ EQ ASCII(PNG) THEN

Present(PNGSig,

IHDR

IDAT,

IEND)

2 M 13.999-

IF $\{13.999\}$ EQ ASCII(WSQ20) THEN

DATA WSQ Present(SOI-WSQ,SOF-WSQ,SOB-WSQ,EOI-WSQ)

Valid

2 M 13.999- IF $\{13.011\}$ EQ ASCII(WSQ20) THEN

DATA WSQ \{Encoder Version $\}$ EQ 2

inches or greater in height. WSQ shall not

be used for other than the 500 ppi class. 
Table C.13 - Assertions for Record Type 14 - Fingerprint Image Record

\begin{tabular}{|c|c|c|c|c|c|c|c|c|c|c|c|}
\hline $\begin{array}{l}\text { Requireme } \\
\text { nt } \\
\text { ID }\end{array}$ & $\begin{array}{c}\text { Referen } \\
\text { ce in } \\
\text { Base } \\
\text { Standar } \\
\text { d }\end{array}$ & $\begin{array}{l}\text { Requirement } \\
\text { Summary }\end{array}$ & $\begin{array}{l}\text { L } \\
\text { e } \\
\text { v } \\
\text { e } \\
\text { I }\end{array}$ & $\begin{array}{l}\mathrm{S} \\
\mathrm{t} \\
\mathrm{a} \\
\mathrm{t} \\
\mathrm{u} \\
\mathrm{s}\end{array}$ & $\begin{array}{l}\text { Assertion } \\
\text { ID }\end{array}$ & $\begin{array}{l}\text { Test } \\
\text { Assertion }\end{array}$ & $\begin{array}{l}\text { Test } \\
\text { Note }\end{array}$ & $\begin{array}{l}\text { Implemen } \\
\text { tation } \\
\text { Support }\end{array}$ & $\begin{array}{l}\text { Supporte } \\
\text { d Range }\end{array}$ & $\begin{array}{l}\text { Test } \\
\text { Result }\end{array}$ & $\begin{array}{l}\text { Applicab } \\
\text { ility }\end{array}$ \\
\hline \multicolumn{12}{|c|}{ 8.14: Record Type-14: Fingerprint image record } \\
\hline $\begin{array}{l}\text { Record: } \\
\text { Type14- } \\
\text { Fingerprint } \\
\text { Type }\end{array}$ & 8.14 & $\begin{array}{l}\text { The Type-14 record shall contain and be } \\
\text { used to exchange exemplar fingerprint } \\
\text { image data, such as a rolled tenprint, an } \\
\text { identification flat, or a complete friction } \\
\text { ridge exemplar. All fingerprint } \\
\text { impressions shall be acquired from a card, } \\
\text { a single or multiple-finger flat-capture } \\
\text { device, contactless fingerprint sensor that } \\
\text { outputs 2D fingerprint images, or a live- } \\
\text { scan device. Captured images may be } \\
\text { transmitted to agencies that will } \\
\text { automatically extract the desired feature } \\
\text { information from the images for matching } \\
\text { purposes. }\end{array}$ & 3 & M & $\begin{array}{l}\text { Type14- } \\
\text { Fingerprint } \\
\text { Type }\end{array}$ & $\begin{array}{l}<\text { Not Tested. It is not feasible to test if the image } \\
\text { represents an exemplar fingerprint or how the } \\
\text { image was acquired.> }\end{array}$ & $\mathrm{t}-1$ & & & & B \\
\hline \multirow{7}{*}{$\begin{array}{l}\text { Field: } \\
\text { Type14- } \\
\text { Subfield } \\
\text { Occurrence }\end{array}$} & \multirow[t]{7}{*}{ Table 67} & \multirow[t]{7}{*}{$\begin{array}{l}<\text { Table } 67 \text { specifies which fields contain } \\
\text { subfields as well as the number of } \\
\text { occurrences permitted.> }\end{array}$} & 1 & - & $\begin{array}{l}\text { Type14- } \\
\text { Subfields } \\
\text { Zero }\end{array}$ & $\begin{array}{l}\text { Count(Subfields in } 14 .[001 \text { to } 003,005 \text { to } 012 \text {, } \\
\text { 016, 017, 020, 026, 027, 030, 031, 903, 996, } \\
\text { 999]) EQ } 0\end{array}$ & & & & & $\mathrm{~T}$ \\
\hline & & & 1 & M & $\begin{array}{l}14.004- \\
\text { Subfields }\end{array}$ & Count(US_Subfields in 14.004) EQ 1 OR 2 & & & & & $\mathrm{~T}$ \\
\hline & & & 1 & M & $\begin{array}{l}14.013- \\
\text { Subfields }\end{array}$ & Count(US_Subfields in 14.013 ) EQ 1 & & & & & $\mathrm{~T}$ \\
\hline & & & 1 & D & $\begin{array}{l}\text { 14.014- } \\
\text { Subfields }\end{array}$ & Count(US_Subfields in 14.014) EQ 2 & & & & & T \\
\hline & & & & D & $\begin{array}{l}\text { 14.015- } \\
\text { Subfields }\end{array}$ & $\begin{array}{l}\text { <See Requirement ID: “Field: PPC-Subfield } \\
\text { Occurrences"> }\end{array}$ & $\mathrm{t}-2$ & & & & \\
\hline & & & 1 & 0 & $\begin{array}{l}\text { 14.018- } \\
\text { Subfields }\end{array}$ & $\begin{array}{l}\text { Count(RS_Subfields in 14.018) MO [1 to 4] } \\
\text { AND } \\
\text { ForEach(RS_Subfield in 14.018) } \\
\left\{\begin{array}{l}\text { Count(US_Subfields in RS_Subfield) EQ } 2 \\
\}\end{array}\right.\end{array}$ & & & & & $\mathrm{T}$ \\
\hline & & & 1 & D & $14.021-$ & Count(RS_Subfields in 14.021) MO [1 to 4] & & & & & $\mathrm{T}$ \\
\hline
\end{tabular}



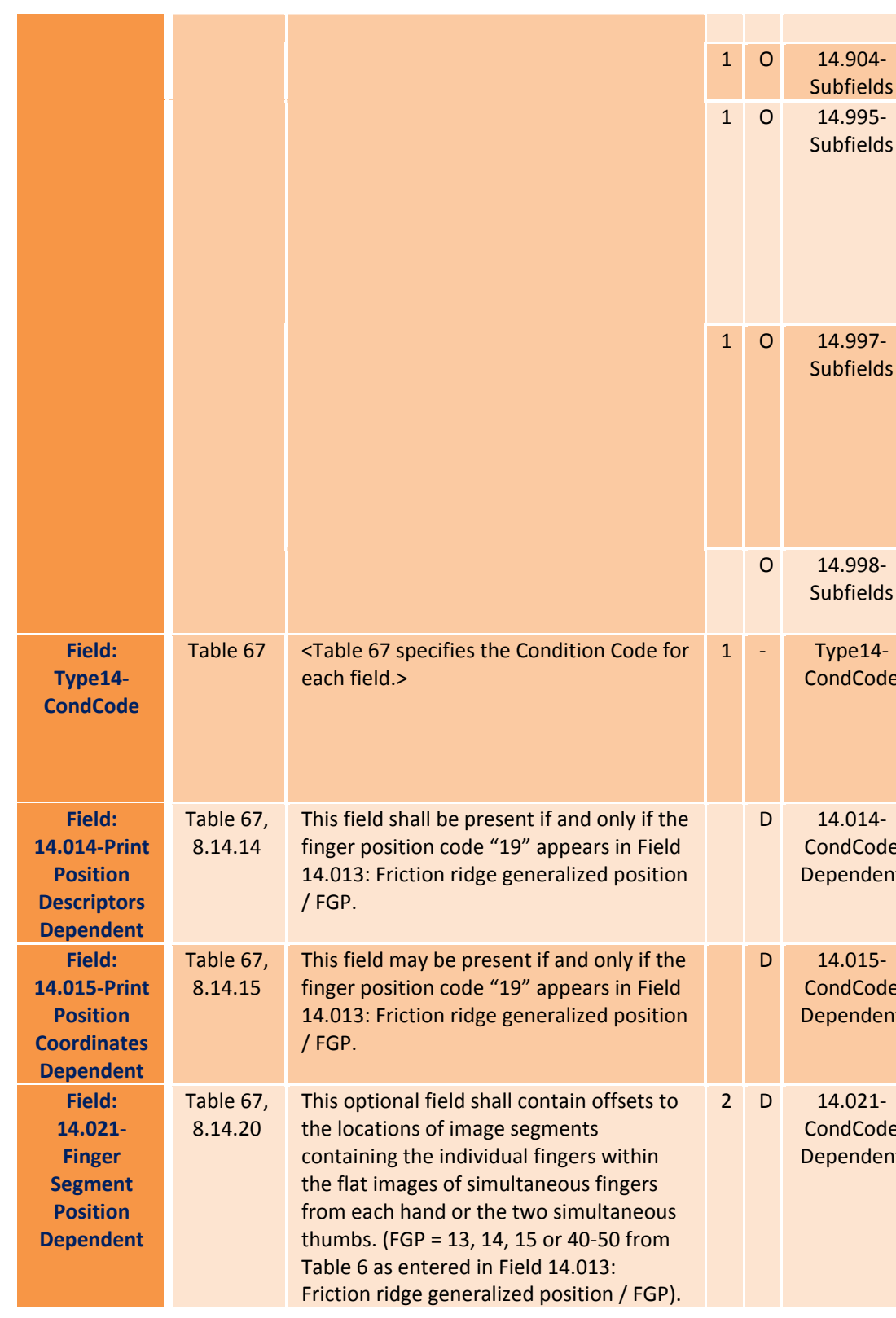

\}

14.995-

Subfields

Table $67 \quad<$ Table 67 specifies the Condition Code for each field.>

$1 \quad 0 \quad 14.997-$

Subfields

Count(RS_Subfields in 14.995) MO [1 to 255]

AND

ForEach(RS Subfield in 14.995)

unt(US_Subfields in RS_Subfield) EQ 1 OR 2

Count(RS_Subfields in 14.997) MO [1 to 255]

AND

ForEach(RS_Subfield in 14.997)

\{

Count(US Subfields in RS Subfield) EQ 1 OR 2

$0 \quad 14.998-$ <See Requirement ID: “Field: GeographicSubfields Conditional">

\section{Present(14.001 to $14.013,14.999)$}

AND

NOT Present $(14.019,14.028,14.029,14.032$ to 14.199, 14.901, 14.905 to 14.994$)$

Table 67, This field shall be present if and only if the 8.14.14 finger position code "19" appears in Field 14.013: Friction ridge generalized position

D 14.014-

CondCode

Dependent / FGP.

Table 67, This field may be present if and only if the 8.14 .15 finger position code " 19 " appears in Field 14.013: Friction ridge generalized position / FGP.

D $14.015-$ CondCode Dependent

This optional field shall contain offsets to the locations of image segments

containing the individual fingers within the flat images of simultaneous fingers

from each hand or the two simultaneous

thumbs. (FGP $=13,14,15$ or $40-50$ from

Table 6 as entered in Field 14.013

Friction ridge generalized position / FGP).

\section{D 14.021- \\ IF \{US_Subfield: 1 in RS Subfield: 1 in 14.013\} MO}

CondCode

Dependent

\begin{tabular}{|l|l|l|l|}
\hline & & \\
\hline & & $T$ \\
\hline
\end{tabular}

<See Requirement ID: “Field: PPD Conditional”>

t-2

<See Requirement ID: “Field: PPD Conditional”

$\mathrm{t}-2$

[3 to 15,40 to 50 ] THEN

Present(14.021) 


\begin{tabular}{|c|c|c|c|c|c|c|c|c|}
\hline $\begin{array}{l}\text { Field: } \\
\text { 14.027- } \\
\text { Stitched } \\
\text { Image Flag } \\
\text { Dependent }\end{array}$ & $\begin{array}{l}\text { Table 67, } \\
8.14 .20\end{array}$ & $\begin{array}{l}\text { This field signifies that images captured } \\
\text { separately were stitched together to form } \\
\text { a single image. This field is mandatory if } \\
\text { an image has been stitched, and the value } \\
\text { shall be set to 'Y'. Otherwise, this field } \\
\text { shall not appear in the record. }\end{array}$ & 3 & $\mathrm{D}$ & $\begin{array}{l}\text { 14.027- } \\
\text { CondCode } \\
\text { Dependent }\end{array}$ & $\begin{array}{l}<\text { Not Tested. It is not feasible to detect if the } \\
\text { image was stitched. }>\end{array}$ & $\mathrm{t}-1$ & B \\
\hline \multirow{5}{*}{$\begin{array}{l}\text { Field: } \\
\text { Type14- } \\
\text { CharType }\end{array}$} & \multirow[t]{5}{*}{$\begin{array}{l}\text { 8.14, } \\
\text { Table } 67\end{array}$} & \multirow[t]{5}{*}{$\begin{array}{l}<\text { Table } 67 \text { specifies the Character Type for } \\
\text { each field that contains no subfields.> }\end{array}$} & 1 & - & $\begin{array}{l}\text { Type14- } \\
\text { CharType N }\end{array}$ & $\begin{array}{l}\text { Bytes }(14 .[001,002,003,005 \text { to } 010,012,016 \\
017,026,031]) \mathrm{MO}[0 \times 30 \text { to } 0 \times 39]\end{array}$ & & B \\
\hline & & & 1 & - & $\begin{array}{l}\text { Type14- } \\
\text { CharType A }\end{array}$ & $\begin{array}{l}\text { Bytes(14.[011, 027, 030]) [0x41 to } 0 \times 5 \mathrm{~A}, 0 \times 61 \text { to } \\
0 \times 7 \mathrm{~A}]\end{array}$ & & B \\
\hline & & & 1 & 0 & $\begin{array}{l}\text { 14.020- } \\
\text { CharType } \\
\text { ANS }\end{array}$ & Bytes(14.020) MO [0x20, 0x7E] & & B \\
\hline & & & 1 & 0 & $\begin{array}{l}\text { 14.903- } \\
\text { CharType } \\
\text { Text ANS }\end{array}$ & Bytes $\{14.903\} \mathrm{MO}[0 \times 20,0 x 7 \mathrm{E}]$ & & B \\
\hline & & & 1 & 0 & $\begin{array}{l}\text { 14.996- } \\
\text { CharType H }\end{array}$ & $\begin{array}{l}\text { Bytes(10.996) MO [0x30 to } 0 \times 39,0 \times 41 \text { to } 0 \times 46 \text {, } \\
\text { 0x61 to } 0 \times 66 \text { ] }\end{array}$ & & B \\
\hline \multirow{5}{*}{$\begin{array}{l}\text { Field: } \\
\text { Type14- } \\
\text { Subfield } \\
\text { CharType }\end{array}$} & \multirow[t]{5}{*}{$\begin{array}{c}\text { 8.14, } \\
\text { Table } 67\end{array}$} & \multirow[t]{5}{*}{$\begin{array}{l}<\text { Table } 67 \text { specifies the Character Type for } \\
\text { each subfield.> }\end{array}$} & 1 & M & $\begin{array}{l}\text { 14.004- } \\
\text { Subfield } \\
\text { CharType U }\end{array}$ & Present( Bytes( US_Subfields:1,2 in 14.004) & & $\mathrm{B}^{*}$ \\
\hline & & & 1 & M & $\begin{array}{l}\text { 14.013- } \\
\text { Subfield } \\
\text { CharType N }\end{array}$ & $\begin{array}{l}\text { Bytes(All(US_Subfields in 14.013)) MO [0x30 to } \\
\text { 0x39] }\end{array}$ & & $\mathrm{B}^{*}$ \\
\hline & & & 1 & $\mathrm{D}$ & $\begin{array}{l}\text { 14.014- } \\
\text { Subfield } \\
\text { CharType } \\
\text { AN }\end{array}$ & 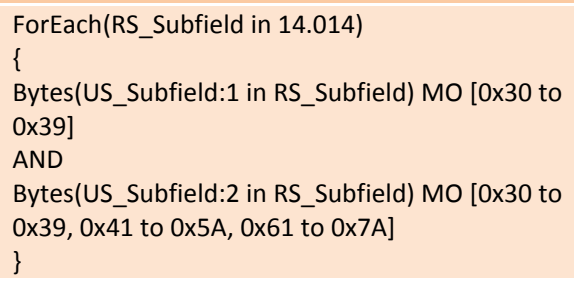 & & $\mathrm{B}^{*}$ \\
\hline & & & 1 & $\mathrm{D}$ & $\begin{array}{c}14.015- \\
\text { Subfield } \\
\text { CharType } \\
\text { AN }\end{array}$ & 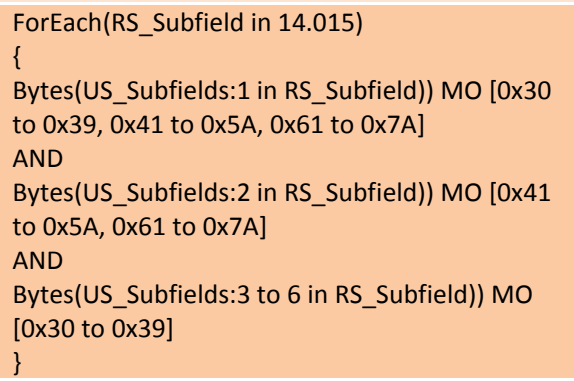 & & $\mathrm{B}^{*}$ \\
\hline & & & 1 & 0 & 14.018- & ForEach(RS_Subfield in 14.018) & & $\mathrm{B}^{*}$ \\
\hline
\end{tabular}




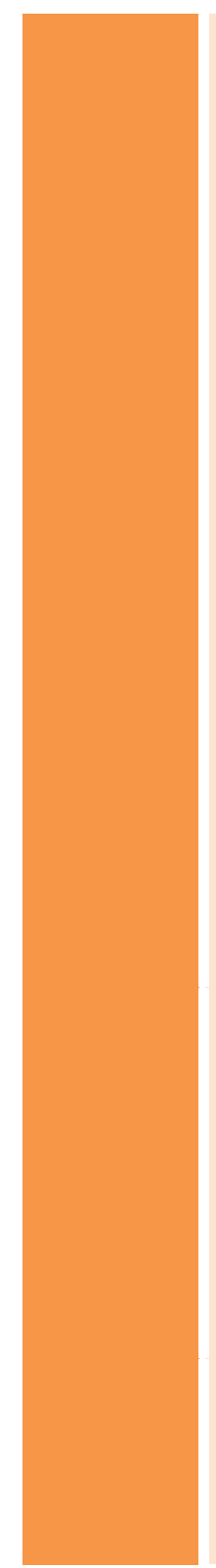

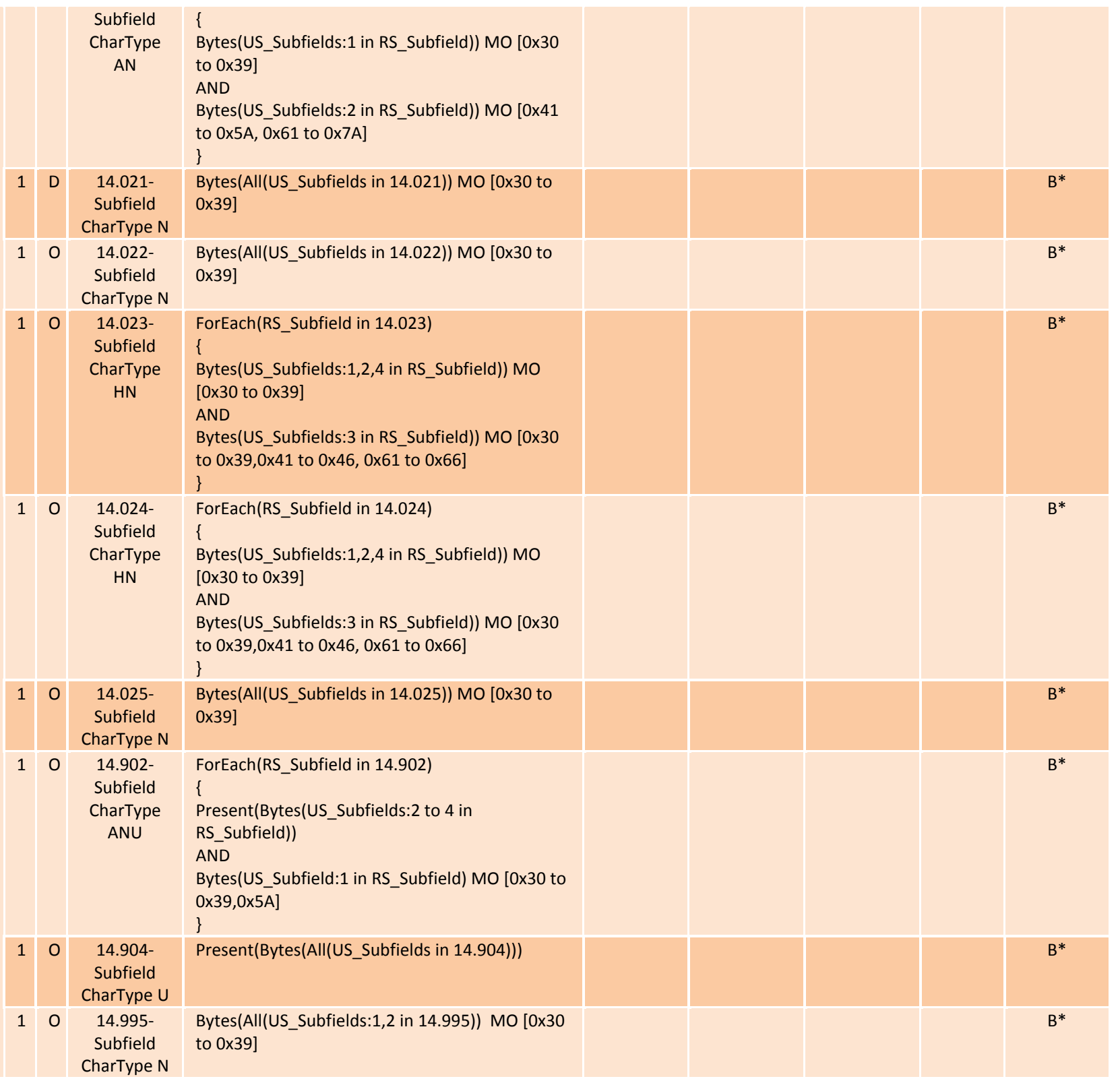



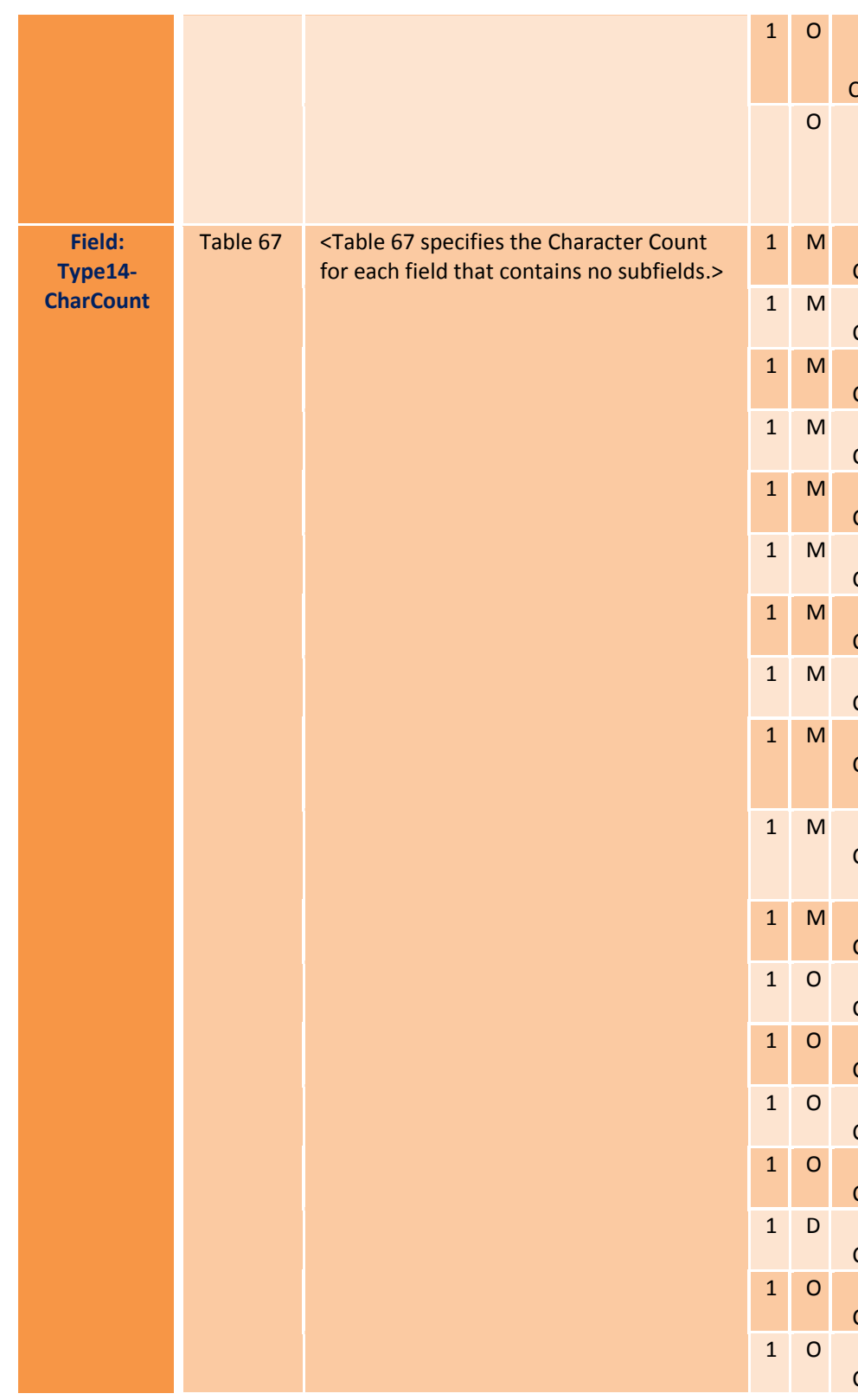

$14.997-$
Subfield CharType N

14.998-

Subfield

CharType

ANSU

1 M $\begin{gathered}14.001- \\ \text { CharCount }\end{gathered}$

1 M $\begin{gathered}14.002- \\ \text { CharCount }\end{gathered}$

1 M 14.003-

CharCount

1 M $\begin{gathered}14.005- \\ \text { CharCount }\end{gathered}$

1 M 14.006-

CharCount

1 M 14.007-

1 M 14.008-

CharCount

1 M 14.009-

1 M 14.010CharCount

1 M 14.011CharCount

$1 \mathrm{M} \quad 14.012-$

10 14.016CharCount

10 14.017-

10 14.020CharCount

10 14.026-

1 D $14.027-$ CharCount

10 14.030-

CharCount

10 14.031-

(All(US Subfields:1,2 in 14.997)) MO [0×30 to $0 \times 39$

<See Requirement ID: "Field: Geographic">

DataLength(14.001) GTE 1

Datalength(14.002) EQ 1 OR 2

DataLength(14.003) EQ 1 OR 2

DataLength(14.005) EQ 8

DataLength(14.006) MO [2 to 5]

DataLength(14.007) MO [2 to 5]

DataLength(14.008) EQ 1

DataLength(14.009) MO [1 to 5]

DataLength(14.010) MO [1 to 5]

DataLength(14.011) MO [3 to 5]

DataLength(14.012) EQ 1 OR 2

DataLength(14.016) MO [1 to 4]

DataLength(14.017) MO [1 to 4]

Datalength(14.020) MO [1 to 126]

DataLength(14.026) MO [1 to 3]

DataLength(14.027) EQ

DataLength(14.030) MO [8 to 10$]$

DataLength(14.031) EQ 2 


\begin{tabular}{|c|c|c|c|c|c|c|c|}
\hline & & & 1 & 0 & $\begin{array}{l}\text { 14.903- } \\
\text { CharCount }\end{array}$ & DataLength(14.903) MO [13 to 16$]$ & B \\
\hline & & & 1 & 0 & $\begin{array}{l}\text { 14.996- } \\
\text { CharCount }\end{array}$ & DataLength(14.995) EQ 64 & B \\
\hline & & & 1 & M & $\begin{array}{l}\text { 14.999- } \\
\text { CharCount }\end{array}$ & DataLength(14.999) GTE 1 & B \\
\hline \multirow{7}{*}{$\begin{array}{l}\text { Field: } \\
\text { Type14- } \\
\text { Subfield } \\
\text { CharCount }\end{array}$} & \multirow[t]{7}{*}{ Table 67} & \multirow[t]{7}{*}{$\begin{array}{l}<\text { Table } 67 \text { specifies the Character Count } \\
\text { for each subfield.> }\end{array}$} & 1 & M & $\begin{array}{l}\text { 14.004- } \\
\text { Subfield } \\
\text { CharCount }\end{array}$ & Length(All(US_Subfields in 14.004)) GTE 1 & $B^{*}$ \\
\hline & & & 1 & M & $\begin{array}{l}\text { 14.013- } \\
\text { Subfield } \\
\text { CharCount }\end{array}$ & Length(All(US_Subfields in 14.013)) EQ 1 OR 2 & $B^{*}$ \\
\hline & & & 1 & D & $\begin{array}{l}\text { 14.014- } \\
\text { Subfield } \\
\text { CharCount }\end{array}$ & $\begin{array}{l}\text { Length(US_Subfield:1 in 14.014) EQ } 1 \text { OR } 2 \\
\text { AND } \\
\text { Length(US_Subfield:2 in 14.014) EQ } 3\end{array}$ & $\mathrm{~B}^{*}$ \\
\hline & & & 1 & D & $\begin{array}{l}\text { 14.015- } \\
\text { Subfield } \\
\text { CharCount }\end{array}$ & $\begin{array}{l}\text { ForEach(RS_Subfield in 14.015) } \\
\{ \\
\text { Length(US_Subfields: } 1 \text { in RS_Subfield) EQ } 2 \text { OR } 3 \\
\text { AND } \\
\text { Length(US_Subfields: } 2 \text { in RS_Subfield) EQ } 3 \\
\text { AND } \\
\text { Length(US_Subfields: } 3 \text { to } 6 \text { in RS_Subfield) MO } \\
\text { [1 to 5] } \\
\text { \} }\end{array}$ & $\mathrm{B}^{*}$ \\
\hline & & & 1 & 0 & $\begin{array}{l}\text { 14.018- } \\
\text { Subfield } \\
\text { CharCount }\end{array}$ & $\begin{array}{l}\text { ForEach(RS_Subfield in 14.018) } \\
\{ \\
\text { Length(US_Subfields: } 1 \text { in RS_Subfield) EQ } 1 \text { OR } 2 \\
\text { AND } \\
\text { Length(US_Subfields:2 in RS_Subfield) EQ } 2 \\
\}\end{array}$ & $\mathrm{B}^{*}$ \\
\hline & & & 1 & D & $\begin{array}{l}\text { 14.021- } \\
\text { Subfield } \\
\text { CharCount }\end{array}$ & $\begin{array}{l}\text { ForEach(RS_Subfield in 14.021) } \\
\{ \\
\text { Length(US_Subfields: } 1 \text { in RS_Subfield) EQ } 1 \text { OR } 2 \\
\text { AND } \\
\text { Length(US_Subfields: } 2 \text { to } 5 \text { in RS_Subfield) MO } \\
\text { [1 to 5] } \\
\}\end{array}$ & $B^{*}$ \\
\hline & & & 1 & 0 & $\begin{array}{l}\text { 14.022- } \\
\text { Subfield } \\
\text { CharCount }\end{array}$ & $\begin{array}{l}\text { ForEach(RS_Subfield in 14.022) } \\
\{ \\
\text { Length(US_Subfields:1 in RS_Subfield) EQ } 1 \text { OR } 2 \\
\text { AND }\end{array}$ & $B^{*}$ \\
\hline
\end{tabular}



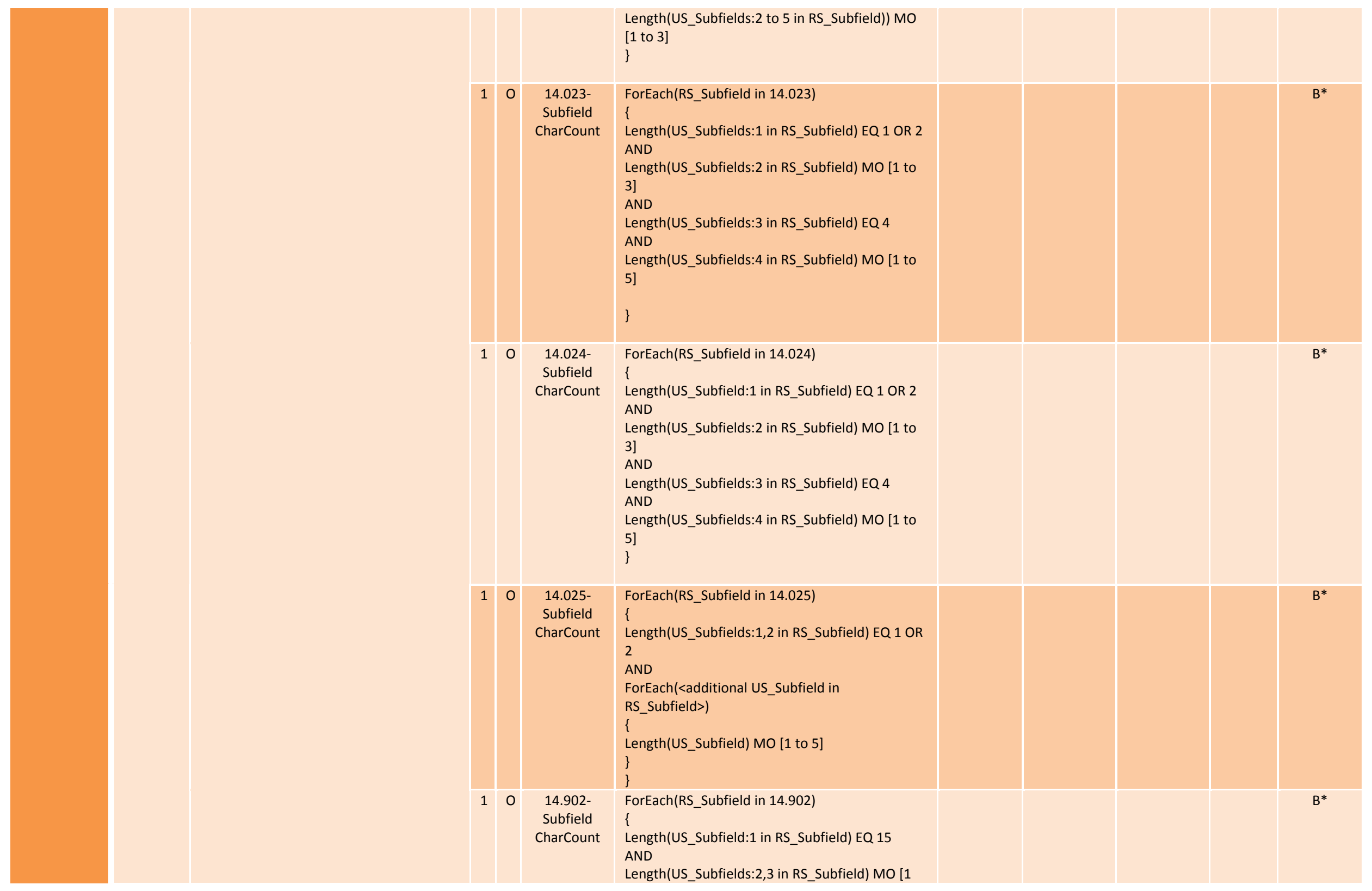


\begin{tabular}{|c|c|c|c|c|c|c|c|c|}
\hline & & & & & & $\begin{array}{l}\text { to } 64] \\
\text { AND } \\
\text { Length(US_Subfield:4 in RS_Subfield) MO [ } 1 \text { to } \\
255] \\
\}\end{array}$ & & \\
\hline & & & 1 & 0 & $\begin{array}{l}\text { 14.904- } \\
\text { Subfield } \\
\text { CharCount }\end{array}$ & Length(All(US_Subfields in 14.904) MO [1 to 50] & & $B^{*}$ \\
\hline & & & 1 & 0 & $\begin{array}{l}\text { 14.995- } \\
\text { Subfield } \\
\text { CharCount }\end{array}$ & 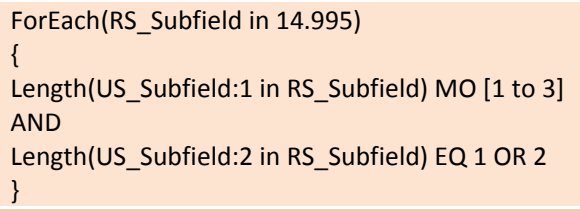 & & $B^{*}$ \\
\hline & & & 1 & 0 & $\begin{array}{l}\text { 14.997- } \\
\text { Subfield } \\
\text { CharCount }\end{array}$ & 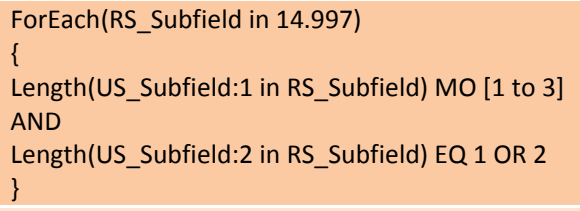 & & $B^{*}$ \\
\hline & & & & 0 & $\begin{array}{l}\text { 14.998- } \\
\text { Subfield } \\
\text { CharCount }\end{array}$ & <See Requirement ID: “Field: Geographic"> & $\mathrm{t}-2$ & \\
\hline $\begin{array}{l}\text { Field: } \\
\text { Type14-Field } \\
\text { Occurrence }\end{array}$ & Table 67 & $\begin{array}{l}<\text { Table } 67 \text { specifies the Field Occurrence } \\
\text { for each field.> }\end{array}$ & 1 & - & $\begin{array}{l}\text { Type14- } \\
\text { Occurrence } \\
\text { Zero }\end{array}$ & $\begin{array}{l}\text { Count(14. [019, } 028,029,032 \text { to } 199,901,905 \text { to } \\
\text { 994]) EQ } 0\end{array}$ & & B \\
\hline & & & 1 & M & $\begin{array}{l}\text { Type14- } \\
\text { Occurrence } \\
\text { One }\end{array}$ & Count(14.[001 to 013, 999]) EQ 1 & & B \\
\hline & & & 1 & - & $\begin{array}{l}\text { Type14- } \\
\text { Occurrence } \\
\text { One or } \\
\text { Fewer }\end{array}$ & $\begin{array}{l}\text { Count(14.[014 to } 018,020 \text { to } 027,030,031,902 \\
\text { to } 904,995 \text { to } 998) \text { LTE } 1\end{array}$ & & B \\
\hline $\begin{array}{l}\text { Field: } \\
\text { 14.001- } \\
\text { Record } \\
\text { Header }\end{array}$ & $\begin{array}{c}\text { 8.14.1, } \\
\text { Table 67, } \\
7.1\end{array}$ & $\begin{array}{l}\text { Field } 14.001 \text { Record header. In Traditional } \\
\text { encoding, this field contains the record } \\
\text { length in bytes (including all information } \\
\text { separators) }\end{array}$ & & M & $\begin{array}{l}\text { 14.001- } \\
\text { Record } \\
\text { Header }\end{array}$ & $\begin{array}{l}<\text { See Requirement ID "Field: xx.001-Record } \\
\text { Header"> }\end{array}$ & $\mathrm{t}-2$ & \\
\hline Value & $\begin{array}{l}8.14 .1 \\
\text { C.10.12 }\end{array}$ & $\begin{array}{l}\text { The XML name for the Type- } 14 \text { record is } \\
<i t l: P a c k a g e F i n g e r p r i n t / m a g e \text { Record }>\text {, } \\
\text { and its <biom:RecordCategoryCode> } \\
\text { element shall } \\
\text { have a value of "14". }\end{array}$ & 1 & M & $\begin{array}{l}\text { NIEM- } \\
14.001- \\
\text { Record } \\
\text { Header }\end{array}$ & 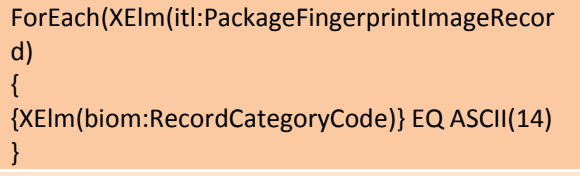 & & $\mathrm{x}$ \\
\hline $\begin{array}{l}\text { Field: } \\
\text { 14.002- } \\
\text { Information } \\
\text { Designation }\end{array}$ & $\begin{array}{l}\text { 8.14.2 } \\
\text { Table } 67 \\
7.3 .1\end{array}$ & $\begin{array}{l}\text { This mandatory field shall be the IDC of } \\
\text { this Type-14 record as found in the } \\
\text { information item IDC of Field } 1.003 \\
\text { Transaction content/CNT. }\end{array}$ & & M & 14.002-IDC & $\begin{array}{l}\text { <See Requirement IDs "Field: xx.002-IDC "and } \\
\text { "Field: 1.003-Transaction Content Subfield } 2 \text { IDC } \\
\text { Matches" > }\end{array}$ & $\mathrm{t}-2$ & \\
\hline
\end{tabular}




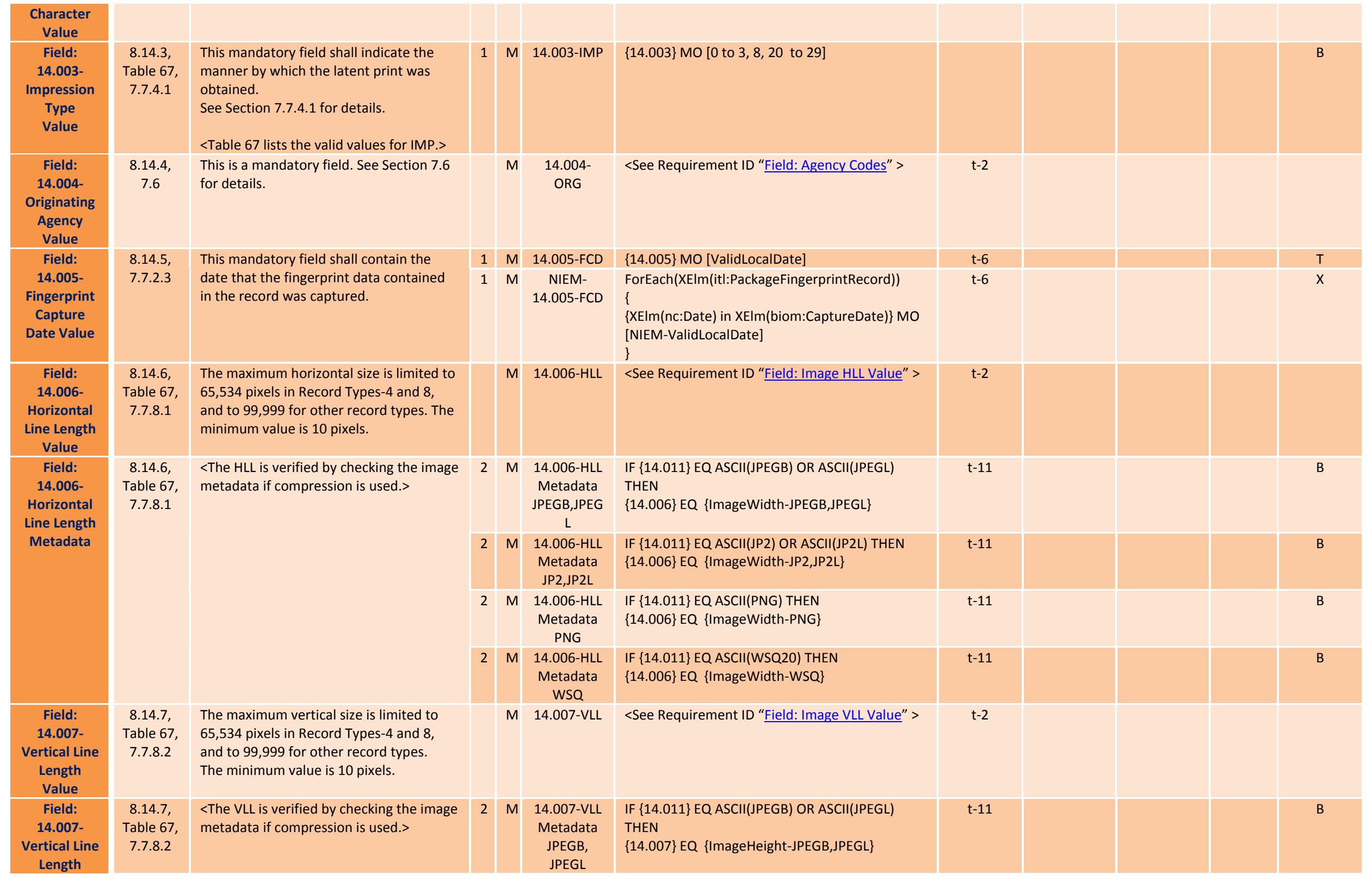




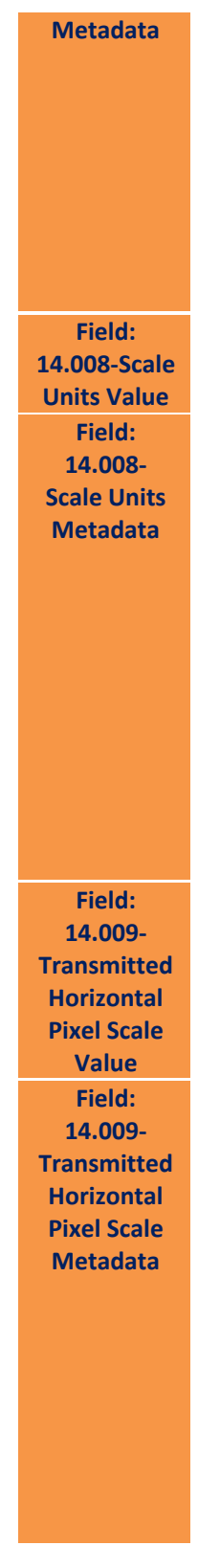

\begin{tabular}{|c|c|}
\hline $\begin{array}{c}\text { 8.14.8, } \\
\text { Table 67, } \\
\text { 7.7.8.3 }\end{array}$ & $\begin{array}{l}<\text { Table } 67 \text { lists the value constraints for } \\
\text { SLC> }\end{array}$ \\
\hline $\begin{array}{c}\text { 8.14.8, } \\
\text { Table 67, } \\
\text { 7.7.8.3 }\end{array}$ & $\begin{array}{l}\text { A value of " } 1 \text { " shall indicate pixels per } \\
\text { inch. } \\
\text { A value of " } 2 \text { " shall indicate pixels per } \\
\text { centimeter. A value of "0" in this field } \\
\text { indicates that no scale is provided, and } \\
\text { the quotient of THPS/TVPS shall provide } \\
\text { the pixel aspect ratio. } \\
\text { <The SLC is verified by checking the image } \\
\text { metadata if compression is used.> }\end{array}$ \\
\hline $\begin{array}{c}\text { 8.14.9, } \\
\text { Table 67, } \\
7.7 .8 .4\end{array}$ & $\begin{array}{l}<\text { Table } 67 \text { lists the value constraints for } \\
\text { THPS.> }\end{array}$ \\
\hline $\begin{array}{c}\text { 8.14.9, } \\
\text { Table 67, } \\
\text { 7.7.8.4 }\end{array}$ & $\begin{array}{l}\text { This is the integer pixel density used in } \\
\text { the horizontal direction of the image if } \\
S L C \text { has a value of " } 1 \text { " or " } 2 \text { ". If SLC has a } \\
\text { value of " } 0 \text { ", this information item shall } \\
\text { contain the horizontal component of the } \\
\text { pixel aspect ratio, up to } 5 \text { digits. } \\
<\text { The THPS is verified by checking the } \\
\text { image metadata if compression is used.> }\end{array}$ \\
\hline
\end{tabular}
2 M 14.007-VLL Metadata
JP2, JP2L
2 M 14.007-VLL Metadat PNG

2 M 14.006-VLL Metadata

WSO

M 14.008-SLC

2 M 14.008-SLC Metadata JPEGB,JPEG

$$
\mathrm{L}
$$

14.008-SLC Metadata
JP2,JP2L

2 M 14.008-SLC Metadata PNG

\subsection{8-SLC Metadata \\ WSQ}

M 14.009THPS

IF $\{14.011\}$ EQ ASCII(JP2) OR ASCII(JP2L) THEN \{14.007\} EQ \{ImageHeight-JP2,JP2L\}

IF $\{14.011\}$ EQ ASCII(PNG) THEN $\{14.007\}$ EQ \{ImageHeight-PNG

IF $\{14.011\}$ EQ ASCII(WSQ20) THEN

\{14.007\} EQ \{ImageHeight-WSQ\}

<Se Requirement ID "Field: Image SLCV Value" >

IF $\{14.011\}$ EQ ASCII(JPEGB) OR ASCII(JPEGL)

THEN $\{14.008\}$ EQ \{SamplingUnits-JPEGB,JPEGL\}

$\mathrm{t}-11$

t-11

$<$ Not Tested.>

IF $\{14.011\}$ EQ ASCII(PNG) THEN

IF $\{14.008\}$ EQ 1 OR 2 THEN \{ SamplingUnits-

PNG EQ 1, ELSE IF $\{14.008\}$ EQ 0 THEN \{

SamplingUnits-PNG EQ 0

$<$ Not Tested.>

$>$ Se

2 M 14.009-

THPS

Metadata

JPEGB,JPEG

L

14.009-

$14.009-$
THPS

Metadata

JP2, JP2L

2 M 14.009-

THPS

Metadata

PNG

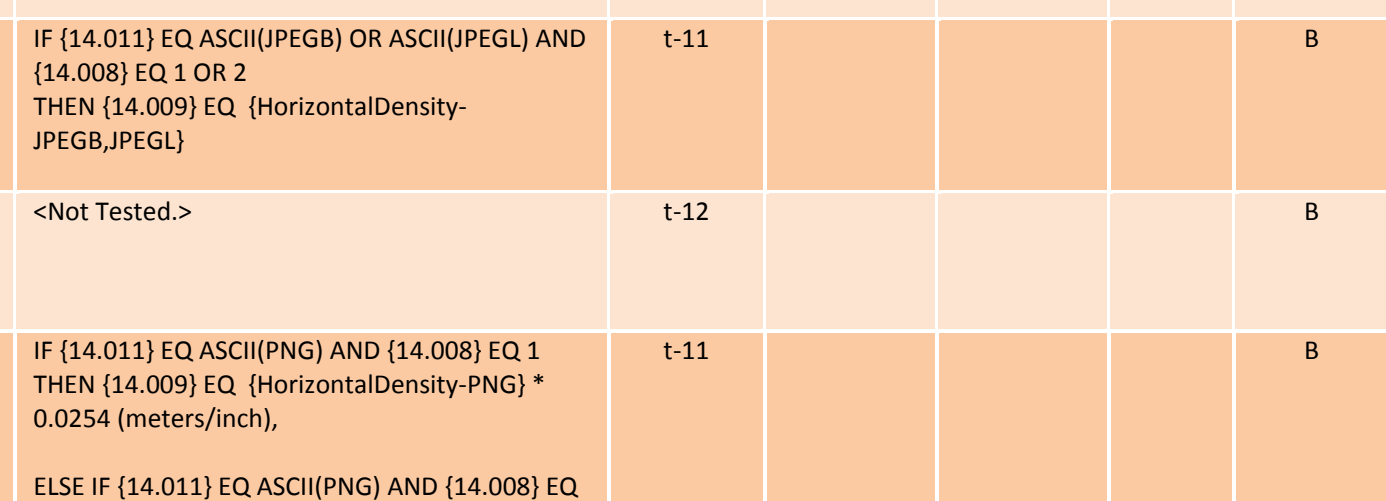




\begin{tabular}{|c|c|c|c|c|c|c|c|c|}
\hline & & & & & & $\begin{array}{l}2 \\
\text { THEN }\{14.009\} \text { EQ }\{\text { HorizontalDensity-PNG }\} \text { * } \\
0.01 \text { (meters/cm) }\end{array}$ & & \\
\hline & & & & & $\begin{array}{l}\text { 14.009- } \\
\text { THPS } \\
\text { Metadata } \\
\text { WSQ }\end{array}$ & $<$ Not Tested. $>$ & $\mathrm{t}-12$ & B \\
\hline & & & 2 & M & $\begin{array}{c}\text { 14.009- } \\
\text { THPS } \\
\text { Aspect } \\
\text { Ratio } \\
\text { Metadata } \\
\text { JPEGB,JPEG } \\
\text { L }\end{array}$ & $\begin{array}{l}\text { IF }\{14.011\} \text { EQ ASCII(JPEGB) OR ASCII(JPEGL) AND } \\
\{14.008\} \text { NEQ } 1 \text { OR } 2 \\
\text { THEN }\{14.009\} /\{14.010\} \text { EQ \{HorizontalDensity- } \\
\text { JPEGB,JPEGL\} / \{VerticalDensity-JPEGB,JPEGL\} }\end{array}$ & $\mathrm{t}-11$ & B \\
\hline & & & & & $\begin{array}{l}\text { 14.009- } \\
\text { THPS } \\
\text { Aspect } \\
\text { Ratio } \\
\text { Metadata } \\
\text { JP2, JP2L }\end{array}$ & $<$ Not Tested. $>$ & $\mathrm{t}-12$ & B \\
\hline & & & 2 & M & $\begin{array}{l}\text { 14.009- } \\
\text { THPS } \\
\text { Aspect } \\
\text { Ratio } \\
\text { Metadata } \\
\text { PNG }\end{array}$ & $\begin{array}{l}\text { IF }\{14.011\} \text { EQ ASCII(PNG) AND }\{14.008\} \text { NEQ } 1 \\
\text { OR } 2 \\
\text { THEN }\{14.009\} /\{14.010\} \text { EQ }\{\text { HorizontalDensity- } \\
\text { PNG } / \text { / }\{\text { VerticalDensity-PNG }\}\end{array}$ & $\mathrm{t}-11$ & B \\
\hline & & & & & $\begin{array}{l}\text { 14.009- } \\
\text { THPS } \\
\text { Aspect } \\
\text { Ratio } \\
\text { Metadata } \\
\text { WSQ }\end{array}$ & $<$ Not Tested. $>$ & $\mathrm{t}-12$ & B \\
\hline $\begin{array}{l}\text { Field: } \\
\text { 14.010- } \\
\text { Transmitted } \\
\text { Vertical } \\
\text { Pixel Scale } \\
\text { Value }\end{array}$ & $\begin{array}{l}\text { 8.14.10, } \\
\text { Table } 67, \\
7.7 .8 .5\end{array}$ & $\begin{array}{l}<\text { Table } 67 \text { lists the value constraints for } \\
\text { TVPS.> }\end{array}$ & & M & $\begin{array}{l}\text { 14.010- } \\
\text { TVPS }\end{array}$ & $\begin{array}{l}<\text { See Requirement ID "Field: Image TVPS Value" } \\
>\end{array}$ & $t-2$ & \\
\hline $\begin{array}{l}\text { Field: } \\
\text { 14.010- } \\
\text { Transmitted } \\
\text { Vertical } \\
\text { Pixel Scale }\end{array}$ & $\begin{array}{l}\text { 8.14.10, } \\
\text { Table } 67, \\
7.7 .8 .5\end{array}$ & $\begin{array}{l}\text { This is the integer pixel density used in } \\
\text { the Vertical direction of the image if SLC } \\
\text { has a value of " } 1 \text { " or " } 2 \text { ". If SLC has a } \\
\text { value of " } 0 \text { ", this information item shall } \\
\text { contain the Vertical component of the }\end{array}$ & 2 & M & $\begin{array}{l}\text { 14.010- } \\
\text { TVPS } \\
\text { Metadata } \\
\text { JPEGB,JPEG } \\
\text { L }\end{array}$ & $\begin{array}{l}\text { IF }\{14.011\} \text { EQ ASCII(JPEGB) OR ASCII(JPEGL) } \\
\text { AND }\{14.008\} \text { EQ } 1 \text { OR2 } \\
\text { THEN } \\
\{14.010\} \text { EQ }\{\text { VerticalDensity-JPEGB,JPEGL }\}\end{array}$ & $\mathrm{t}-11$ & B \\
\hline Metadata & & $\begin{array}{l}\text { pixel aspect ratio, up to } 5 \text { digits. } \\
<\text { The TVPS is verified by checking the }\end{array}$ & & & $\begin{array}{l}\text { 14.010- } \\
\text { TVPS } \\
\text { Metadata }\end{array}$ & $<$ Not Tested.> & $\mathrm{t}-12$ & B \\
\hline
\end{tabular}




\begin{tabular}{|c|c|c|c|c|c|c|c|c|}
\hline & & image metadata if compression is used.> & & & $J P 2, J P 2 L$ & & & \\
\hline & & & 2 & M & $\begin{array}{l}\text { 14.010- } \\
\text { TVPS } \\
\text { Metadata } \\
\text { PNG }\end{array}$ & $\begin{array}{l}\text { IF }\{14.011\} \text { EQ ASCII(PNG)) AND }\{14.008\} \text { EQ } 1 \\
\text { THEN }\{14.010\} \text { EQ }\{\text { VerticalDensity-PNG } * \\
0.0254 \text { (meters/inch), } \\
\text { ELSE IF }\{14.011\} \text { EQ ASCII(PNG)) AND }\{14.008\} \text { EQ } \\
2 \\
\text { THEN }\{14.010\} \text { EQ }\{\text { VerticalDensity-PNG }\} * 0.01 \\
\text { (meters/cm) }\end{array}$ & $\mathrm{t}-11$ & B \\
\hline & & & & & $\begin{array}{l}\text { 14.010- } \\
\text { TVPS } \\
\text { Metadata } \\
\text { WSQ }\end{array}$ & $<$ Not Tested. $>$ & $\mathrm{t}-12$ & B \\
\hline & & & 2 & M & $\begin{array}{l}\text { 14.010- } \\
\text { TVPS } \\
\text { Aspect } \\
\text { Ratio } \\
\text { Metadata } \\
\text { JPEGB,JPEG } \\
\text { L }\end{array}$ & $\begin{array}{l}\text { IF }\{14.011\} \text { EQ ASCII(JPEGB) OR ASCII(JPEGL) AND } \\
\{14.008\} \text { NEQ } 1 \text { OR } 2 \\
\text { THEN }\{14.009\} /\{14.010\} \text { EQ \{HorizontalDensity- } \\
\text { JPEGB,JPEGL } / \text { \{VerticalDensity-JPEGB,JPEGL\} }\end{array}$ & $\mathrm{t}-11$ & B \\
\hline & & & & & $\begin{array}{c}\text { 14.010- } \\
\text { TVPS } \\
\text { Aspect } \\
\text { Ratio } \\
\text { Metadata } \\
\text { JP2, JP2L }\end{array}$ & $<$ Not Tested.> & $\mathrm{t}-12$ & B \\
\hline & & & 2 & M & $\begin{array}{c}\text { 14.010- } \\
\text { TVPS } \\
\text { Aspect } \\
\text { Ratio } \\
\text { Metadata } \\
\text { PNG }\end{array}$ & $\begin{array}{l}\text { IF }\{14.011\} \text { EQ ASCII(PNG) AND }\{14.008\} \text { NEQ } 1 \\
\text { OR } 2 \\
\text { THEN }\{14.009\} /\{14.010\} \text { EQ }\{\text { HorizontalDensity - } \\
\text { PNG } /\{\text { VerticalDensity-PNG }\}\end{array}$ & $\mathrm{t}-11$ & B \\
\hline & & & & & $\begin{array}{l}\text { 14.010- } \\
\text { TVPS } \\
\text { Aspect } \\
\text { Ratio } \\
\text { Metadata } \\
\text { WSQ }\end{array}$ & $<$ Not Tested. $>$ & $\mathrm{t}-12$ & B \\
\hline $\begin{array}{l}\text { Field: } \\
\text { 14.011- } \\
\text { Compressio } \\
\text { n Algorithm } \\
\text { Value }\end{array}$ & $\begin{array}{c}\text { 8.14.11, } \\
\text { Table 67, } \\
\text { 7.7.9.1 }\end{array}$ & $\begin{array}{l}\text { For each of these fields, the entry } \\
\text { corresponds to the appropriate Label } \\
\text { entry in Table 12: Field 14.011: } \\
\text { Compression algorithm / CGA. }\end{array}$ & 1 & M & 14.011-CGA & $\begin{array}{l}\{14.011\} \mathrm{MO}[\mathrm{ASCII}(\mathrm{NONE}, \mathrm{JPEGB}, \mathrm{JPEGL}, \mathrm{JP2} \\
\text { JP2L, PNG, WSQ)] }\end{array}$ & $\mathrm{t}-98$ & B \\
\hline $\begin{array}{l}\text { Field: } \\
\text { 14.011- } \\
\text { Compressio }\end{array}$ & $\begin{array}{l}\text { 8.14.11, } \\
\text { Table } 67\end{array}$ & $\begin{array}{l}<\text { The CGA is verified by checking the } \\
\text { image metadata for the compression type } \\
\text { signature if compression is used.> }\end{array}$ & 2 & M & $\begin{array}{l}\text { 14.011- } \\
\text { CGAMetad } \\
\text { ata }\end{array}$ & $\begin{array}{l}\text { IF }\{14.011\} \text { EQ ASCII(JPEGB) OR ASCII(JPEGL) } \\
\text { THEN } \\
\text { Present(SOI -JPEG,JPEGL) }\end{array}$ & $\mathrm{t}-11$ & B \\
\hline
\end{tabular}




\begin{tabular}{|c|c|c|c|c|c|c|c|c|}
\hline \multirow[t]{4}{*}{$\begin{array}{l}\text { n Algorithm } \\
\text { Metadata }\end{array}$} & & & & & $\begin{array}{l}\text { JPEGB,JPEG } \\
\text { L }\end{array}$ & & & \\
\hline & & & 2 & M & $\begin{array}{c}\text { 14.011-CGA } \\
\text { Metadata } \\
\text { JP2, JP2L }\end{array}$ & $\begin{array}{l}\text { IF }\{14.011\} \text { EQ ASCII(JP2) OR ASCII(JP2L) THEN } \\
\text { Present(SigBox) }\end{array}$ & $\mathrm{t}-11$ & B \\
\hline & & & 2 & M & $\begin{array}{c}\text { 14.011-CGA } \\
\text { Metadata } \\
\text { PNG }\end{array}$ & $\begin{array}{l}\text { IF }\{14.011\} \text { EQ ASCII(PNG) THEN } \\
\text { Present(PNGSig) }\end{array}$ & $\mathrm{t}-11$ & B \\
\hline & & & 2 & M & $\begin{array}{c}\text { 14.011-CGA } \\
\text { Metadata } \\
\text { WSQ }\end{array}$ & $\begin{array}{l}\text { IF }\{14.011\} \text { EQ ASCII(WSQ20) THEN } \\
\text { Present(SOI-WSQ) }\end{array}$ & $\mathrm{t}-11$ & B \\
\hline $\begin{array}{l}\text { Field: } \\
\text { 14.012-Bits } \\
\text { Per Pixel } \\
\text { Value }\end{array}$ & $\begin{array}{c}\text { 8.14.12, } \\
\text { Table 67, } \\
\text { 7.7.8.6 }\end{array}$ & $\begin{array}{l}\text { This field shall contain an entry of " } 8 \text { " for } \\
\text { normal grayscale values of " } 0 \text { " to " } 255 \text { ". } \\
\text { Any entry in this field greater than " } 8 \text { " } \\
\text { shall represent a grayscale pixel with } \\
\text { increased proportion. }\end{array}$ & & M & 14.012-BPX & <See Requirement ID “Field: Image BPX Value" > & $\mathrm{t}-2$ & \\
\hline \multirow[t]{4}{*}{$\begin{array}{l}\text { Field: } \\
\text { 14.012- Bits } \\
\text { Per Pixel } \\
\text { Metadata }\end{array}$} & \multirow[t]{4}{*}{$\begin{array}{l}\text { 8.14.12, } \\
\text { Table } 67\end{array}$} & \multirow[t]{4}{*}{$\begin{array}{l}<\text { The BPX is verified by checking the } \\
\text { image metadata for the compression type } \\
\text { signature if compression is used.> }\end{array}$} & 2 & M & $\begin{array}{c}\text { 14.012-BPX } \\
\text { Metadata } \\
\text { JPEGB,JPEG } \\
\text { L }\end{array}$ & $\{14.012\}$ EQ $\{B P X-J P E G, J P E G L\}$ & $\mathrm{t}-11$ & B \\
\hline & & & 2 & M & $\begin{array}{l}\text { 14.012-BPX } \\
\text { Metadata } \\
\text { JP2, JP2L }\end{array}$ & $\{14.012\}$ EQ $\{$ BPX-JP2,JP2L $\}$ & $\mathrm{t}-11$ & B \\
\hline & & & 2 & M & $\begin{array}{c}\text { 14.012-BPX } \\
\text { Metadata } \\
\text { PNG }\end{array}$ & $\{14.012\} \mathrm{EQ}\{\mathrm{BPX}-\mathrm{PNG}\}$ & $\mathrm{t}-11$ & B \\
\hline & & & & & $\begin{array}{c}\text { 14.012-BPX } \\
\text { Metadata } \\
\text { WSQ }\end{array}$ & $<$ Not Tested. $>$ & $\mathrm{t}-12$ & B \\
\hline $\begin{array}{l}\text { Field: } \\
\text { 14.013- } \\
\text { Friction } \\
\text { Ridge } \\
\text { Generalized } \\
\text { Position } \\
\text { Value }\end{array}$ & $\begin{array}{c}\text { 8.14.13, } \\
\text { Table 67, } \\
\text { 7.7.4.2, } \\
\text { Table } 6\end{array}$ & See Section 7.7.4.2 for details. & 1 & M & $\begin{array}{l}\text { 14.013-FGP } \\
\text { Value }\end{array}$ & $\{14.013\} \mathrm{MO}[1$ to 19,33 to 36,40 to 50$]$ & & B \\
\hline $\begin{array}{l}\text { Field: } \\
\text { 14.014- } \\
\text { Search } \\
\text { Position } \\
\text { Descriptors } \\
\text { Value }\end{array}$ & $\begin{array}{c}\text { 8.14.14, } \\
\text { Table 67, } \\
\text { 7.7.4.3 }\end{array}$ & ...described in Section 7.7.4.3 & & $\mathrm{D}$ & $\begin{array}{l}\text { 14.014-PPD } \\
\text { Value }\end{array}$ & <See Requirement ID: “Field: SPD,PPD Values”> & $\mathrm{t}-2$ & \\
\hline $\begin{array}{l}\text { Field: } \\
\text { 14.014- } \\
\text { Search } \\
\text { Position }\end{array}$ & $\begin{array}{l}\text { 8.14.14, } \\
\text { Table } 67\end{array}$ & $\begin{array}{l}\text { This field shall be present if and only if the } \\
\text { finger position code " } 19 \text { " appears in Field } \\
\text { 14.013: Friction ridge generalized position } \\
\text { / FGP. }\end{array}$ & & $\mathrm{D}$ & $\begin{array}{l}\text { 14.014-PPD } \\
\text { Conditional }\end{array}$ & <See Requirement ID: “Field: PPD Conditional"> & $t-2$ & \\
\hline
\end{tabular}




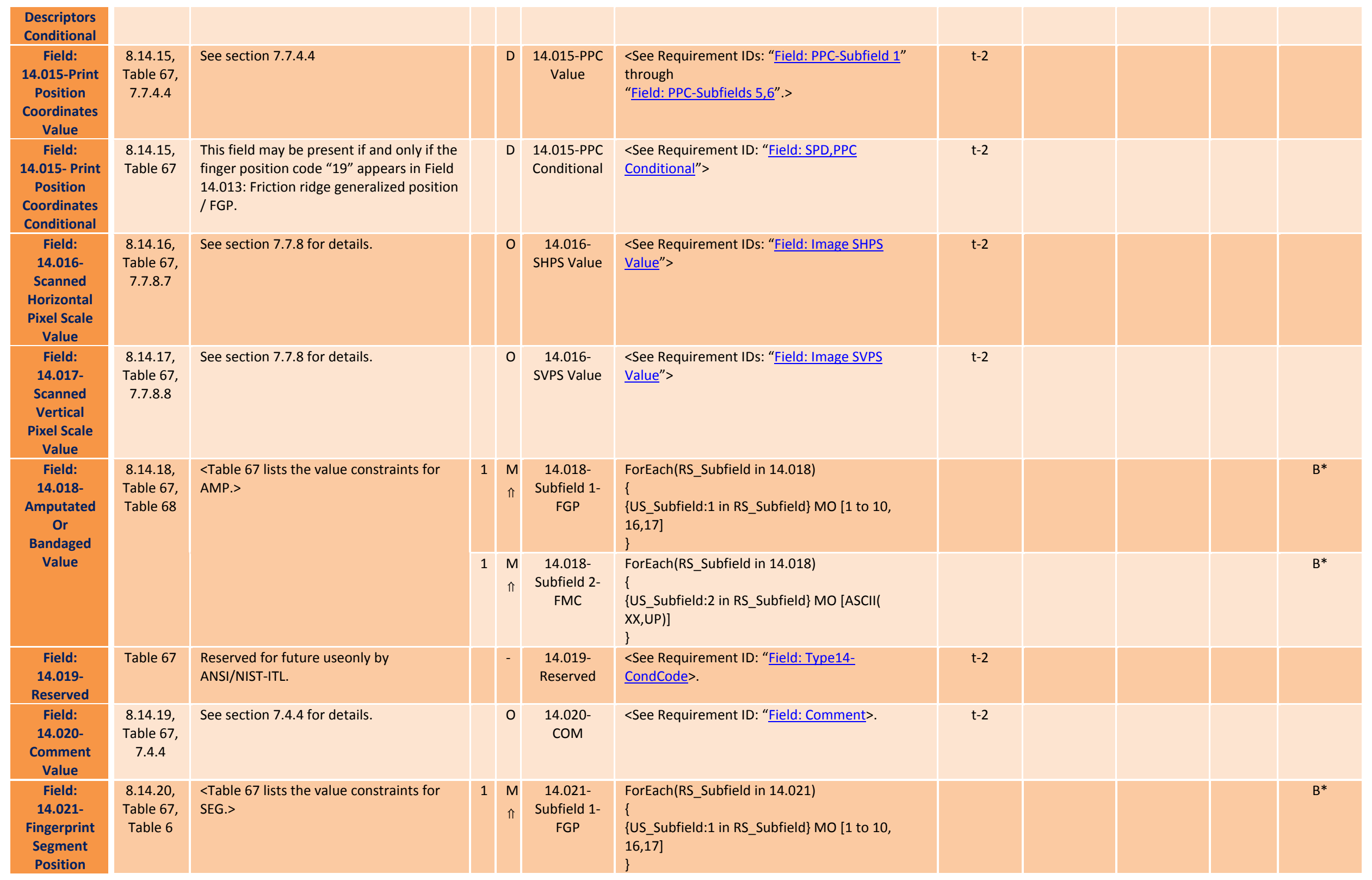




\begin{tabular}{|c|c|c|c|c|c|c|c|c|}
\hline \multirow[t]{4}{*}{ Value } & & & 2 & $\begin{array}{l}M \\
\Uparrow\end{array}$ & $\begin{array}{l}\text { 14.021- } \\
\text { Subfield 2- } \\
\text { LHC }\end{array}$ & $\begin{array}{l}\text { ForEach(RS_Subfield in 14.021) } \\
\{ \\
\{\text { US_Subfield:2 in RS_Subfield }\} \text { LTE }\{14.006\} \\
\}\end{array}$ & & $\mathrm{B}^{*}$ \\
\hline & & & 2 & $\begin{array}{l}\mathrm{M} \\
\Uparrow\end{array}$ & $\begin{array}{l}\text { 14.021- } \\
\text { Subfield 3- } \\
\quad \text { LHC }\end{array}$ & $\begin{array}{l}\text { ForEach(RS_Subfield in 14.021) } \\
\{ \\
\{\text { US_Subfield: } 3 \text { in RS_Subfield }\} \text { LTE }\{14.006\} \text { AND } \\
\text { GTE }\{\text { US_Subfield: } 2 \text { in } 14.021\} \\
\}\end{array}$ & & $\mathrm{B}^{*}$ \\
\hline & & & 2 & $\begin{array}{l}M \\
\Uparrow\end{array}$ & $\begin{array}{l}\text { 14.021- } \\
\text { Subfield 4- } \\
\quad \text { LHC }\end{array}$ & $\begin{array}{l}\text { ForEach(RS_Subfield in 14.021) } \\
\{ \\
\{\text { US_Subfield:4 in RS_Subfield }\} \text { LTE }\{14.007\} \\
\}\end{array}$ & & $\mathrm{B}^{*}$ \\
\hline & & & 2 & $\begin{array}{l}M \\
\Uparrow\end{array}$ & $\begin{array}{l}\text { 14.021- } \\
\text { Subfield 5- } \\
\text { LHC }\end{array}$ & 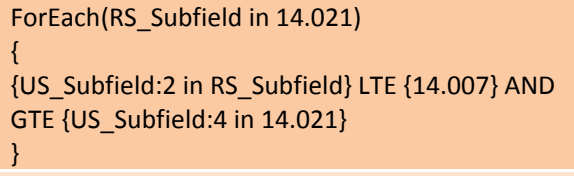 & & $\mathrm{B}^{*}$ \\
\hline $\begin{array}{l}\text { Field: } \\
\text { 14.021- } \\
\text { Fingerprint } \\
\text { Segment } \\
\text { Position } \\
\text { Conditional }\end{array}$ & $\begin{array}{l}\text { 8.14.15, } \\
\text { Table } 67\end{array}$ & $\begin{array}{l}\text { This optional field shall contain offsets to } \\
\text { the locations of image segments } \\
\text { containing the individual fingers within } \\
\text { the flat images of simultaneous fingers } \\
\text { from each hand or the two simultaneous } \\
\text { thumbs. (FGP }=13,14,15 \text { or } 40-50 \text { from } \\
\text { Table } 6 \text { as entered in Field } 14.013 \text { : } \\
\text { Friction ridge generalized position / FGP). }\end{array}$ & & D & $\begin{array}{l}\text { 14.021-SEG } \\
\text { Conditional }\end{array}$ & $\begin{array}{l}<\text { See Requirement ID: "Field: 14.021-Finger } \\
\text { Segment Position Dependent"> }\end{array}$ & $\mathrm{t}-2$ & \\
\hline \multirow[t]{2}{*}{$\begin{array}{l}\text { Field: } \\
\text { 14.022-NIST } \\
\text { Quality } \\
\text { Metric } \\
\text { Value }\end{array}$} & $\begin{array}{c}\text { 8.14.21, } \\
\text { Table 67, } \\
\text { Table } 6\end{array}$ & $\begin{array}{l}<\text { Table } 67 \text { lists the value constraints for } \\
\text { NQM.> }\end{array}$ & 1 & $\begin{array}{c}M \\
\Uparrow\end{array}$ & $\begin{array}{l}\text { 14.022- } \\
\text { Subfield 1- } \\
\text { FGP }\end{array}$ & $\begin{array}{l}\text { ForEach(RS_Subfield in 14.022) } \\
\{ \\
\{\text { US_Subfield:1 in RS_Subfield }\} \text { MO [1 to 10, } \\
16,17] \\
\}\end{array}$ & & $\mathrm{B}^{*}$ \\
\hline & & & 1 & $\begin{array}{l}M \\
\Uparrow\end{array}$ & $\begin{array}{l}\text { 14.022- } \\
\text { Subfield 2- } \\
\text { IQS }\end{array}$ & $\begin{array}{l}\text { ForEach(RS_Subfield in 14.022) } \\
\{ \\
\{\text { US_Subfield:2 in RS_Subfield }\} \text { MO [1 to 5, 254, } \\
255] \\
\}\end{array}$ & & $\mathrm{B}^{*}$ \\
\hline $\begin{array}{l}\text { Field: } \\
\text { 14.023- } \\
\text { Segmentatio } \\
\text { n Qualtiy } \\
\text { Metric } \\
\text { Value }\end{array}$ & $\begin{array}{c}\text { 8.14.22, } \\
\text { Table 67, } \\
\text { Table } 6\end{array}$ & $\begin{array}{l}<\text { Table } 67 \text { lists the value constraints for } \\
\text { SQM.> }\end{array}$ & & $\begin{array}{l}M \\
\Uparrow\end{array}$ & $\begin{array}{l}14.023- \\
\text { SQM }\end{array}$ & $\begin{array}{l}\text { <See Requirement ID: “Field: Sample Quality } \\
\text { Occurrences", “Field: Sample Quality Subfield 1", } \\
\text { "Field: Sample Quality Subfield 2", and "Field: } \\
\text { Sample Quality Subfield 3".> }\end{array}$ & $\mathrm{t}-2$ & \\
\hline $\begin{array}{l}\text { Field: } \\
\text { 14.024- } \\
\text { Finger } \\
\text { Quality }\end{array}$ & $\begin{array}{c}\text { 8.14.23, } \\
\text { Table 67, } \\
\text { Table } 6\end{array}$ & $\begin{array}{l}<\text { Table } 67 \text { lists the value constraints for } \\
\text { FQM.> }\end{array}$ & & 0 & $\begin{array}{l}14.024- \\
\text { FQM }\end{array}$ & $\begin{array}{l}\text { <See Requirement ID: “Field: Sample Quality } \\
\text { Occurrences", “Field: Sample Quality Subfield 1", } \\
\text { "Field: Sample Quality Subfield 2", and "Field: } \\
\text { Sample Quality Subfield 3".> }\end{array}$ & $t-2$ & \\
\hline
\end{tabular}




\begin{tabular}{|c|c|c|c|c|c|c|c|c|}
\hline $\begin{array}{l}\text { Metric } \\
\text { Value }\end{array}$ & & & & & & & & \\
\hline \multirow{3}{*}{$\begin{array}{l}\text { Field: } \\
\text { 14.025- } \\
\text { Alternate } \\
\text { Finger } \\
\text { Segment } \\
\text { Position(s) } \\
\text { Value }\end{array}$} & \multirow[t]{3}{*}{$\begin{array}{l}8.14 .24, \\
\text { Table } 67, \\
\text { Table } 6\end{array}$} & \multirow[t]{3}{*}{$\begin{array}{l}<\text { Table } 67 \text { lists the value constraints for } \\
\text { ASEG.> }\end{array}$} & 1 & $\begin{array}{l}\mathrm{M} \\
\Uparrow\end{array}$ & $\begin{array}{l}14.025- \\
\text { Subfield } 1 \text { - } \\
\text { FGP }\end{array}$ & $\begin{array}{l}\text { ForEach(RS_Subfield in 14.025) } \\
\{ \\
\{\text { US_Subfield:1 in RS_Subfield\} MO [1 to 10, 16, } \\
\text { 17] } \\
\}\end{array}$ & & $B^{*}$ \\
\hline & & & 1 & $\begin{array}{l}M \\
\Uparrow\end{array}$ & $\begin{array}{l}14.025- \\
\text { Subfield 2- } \\
\text { NOP }\end{array}$ & $\begin{array}{l}\text { ForEach(RS_Subfield in } 14.025) \\
\{ \\
\{\text { US_Subfield:2 in RS_Subfield }\} \text { MO [3 to 99] } \\
\}\end{array}$ & & $\mathrm{B}^{*}$ \\
\hline & & & 2 & $\begin{array}{l}\mathrm{M} \\
\Uparrow\end{array}$ & $\begin{array}{l}\text { 14.025- } \\
\text { Subfield } \\
\text { Pair }\end{array}$ & $\begin{array}{l}\text { ForEach(RS_Subfield in 14.025) } \\
\{ \\
\text { For(X EQ } 3 \text { to }\{\text { US_Subfield: } 2 \text { in RS_Subfield }\}) \\
\{ \\
\text { IF X MOD } 2 \text { EQ } 0 \\
\{\text { US_Subfield:X in RS_Subfield }\} \text { GTE } 1 \text { AND LTE } \\
\{14.007\} \\
\text { ELSE } \\
\{\text { US_Subfield:X in RS_Subfield }\} \text { GTE } 1 \text { AND LTE } \\
\{14.006\} \\
\} \\
\}\end{array}$ & & $\mathrm{B}^{*}$ \\
\hline \multirow[t]{3}{*}{$\begin{array}{l}\text { Field: } \\
\text { 14.025- } \\
\text { Alternate } \\
\text { Finger } \\
\text { Segment } \\
\text { Position(s) } \\
\text { Polygon }\end{array}$} & \multirow[t]{3}{*}{$\begin{array}{l}8.14 .24, \\
\text { Table } 67, \\
\text { Section } \\
7.8\end{array}$} & $\begin{array}{l}\text { The order of the vertices shall be in their } \\
\text { consecutive order around the perimeter } \\
\text { of the polygon, either clockwise or } \\
\text { counterclockwise. }\end{array}$ & 2 & 0 & $\begin{array}{l}\text { 14.025- } \\
\text { ASEG Order }\end{array}$ & $\begin{array}{l}<\text { Angle.Direction.First EQ ((X,Y).1 To } \\
(\mathrm{X}, \mathrm{Y}) .2) \text {.Angle.Direction; }((\mathrm{X}, \mathrm{Y}) .2 \text { To N- } \\
1 \text { to }(\mathrm{X}, \mathrm{Y}) .3 \text { To N).Angle.Direction EQ } \\
\text { Angle.Direction.First; ((X,Y).N To } \\
(\mathrm{X}, \mathrm{Y}) .1 \text { ).Angle.Direction EQ } \\
\text { Angle.Direction.First.> }\end{array}$ & & $B^{*}$ \\
\hline & & $\begin{array}{l}\text { No two vertices may occupy the same } \\
\text { location. }\end{array}$ & 2 & $\mathrm{O}$ & $\begin{array}{l}14.025- \\
\text { ASEG } \\
\text { Polygon }\end{array}$ & $<$ Each Vertex $(\mathrm{X}, \mathrm{Y})$ is unique $>$ & & $B^{*}$ \\
\hline & & $\begin{array}{l}\text { The polygon side defined by the last } \\
\text { vertex and the first vertex shall complete } \\
\text { the polygon. } \\
\text { The polygon shall be a simple, plane } \\
\text { figure with no sides crossing and no } \\
\text { interior holes. }\end{array}$ & 2 & 0 & $\begin{array}{l}\text { 14.025- } \\
\text { ASEG } \\
\text { Polygon }\end{array}$ & $<$ Not Tested.> & $t-14$ & \\
\hline $\begin{array}{l}\text { Field: } \\
\text { 14.026- } \\
\text { Simultaneou } \\
\text { s Capture } \\
\text { Value }\end{array}$ & $\begin{array}{l}8.14 .25 \\
\text { Table } 67\end{array}$ & $\begin{array}{l}<\text { Table } 67 \text { lists the value constraints for } \\
\text { SCF.> }\end{array}$ & 1 & 0 & 14.026-SCF & $\{14.026\} \mathrm{MO}$ [1 to 255$]$ & & B \\
\hline $\begin{array}{l}\text { Field: } \\
\text { 14.027- } \\
\text { Stitched }\end{array}$ & $\begin{array}{l}\text { 8.14.26, } \\
\text { Table } 67\end{array}$ & $\begin{array}{l}<\text { Table } 67 \text { lists the value constraints for } \\
\text { SCF.> }\end{array}$ & 1 & D & 14.027-SIF & $\{14.027\}$ EQ ASCII(Y) & & B \\
\hline
\end{tabular}




\begin{tabular}{|c|}
\hline $\begin{array}{c}\text { Image Flag } \\
\text { Value }\end{array}$ \\
\hline $\begin{array}{l}\text { Field: } \\
\text { 14.027- } \\
\text { Stitched } \\
\text { Image Flag } \\
\text { Conditional }\end{array}$ \\
\hline $\begin{array}{c}\text { Field: } \\
\text { 14.028, } \\
\text { 14.029- } \\
\text { Reserved }\end{array}$ \\
\hline $\begin{array}{l}\text { Field: } \\
14.030- \\
\text { Device } \\
\text { Monitoring } \\
\text { Mode Value }\end{array}$ \\
\hline $\begin{array}{l}\text { Field: } \\
\text { 14.031- } \\
\text { Subject } \\
\text { Acquisition } \\
\text { Profile- } \\
\text { Fingerprint } \\
\text { Value }\end{array}$ \\
\hline $\begin{array}{c}\text { Field: } 14.032 \\
\text { to } 14.199- \\
\text { Reserved }\end{array}$ \\
\hline $\begin{array}{c}\text { Field: } 14.200 \\
\text { to } 14.900- \\
\text { User } \\
\text { Defined }\end{array}$ \\
\hline $\begin{array}{c}\text { Field: } \\
\text { 14.901- } \\
\text { Reserved }\end{array}$ \\
\hline $\begin{array}{c}\text { Field: } \\
\text { 14.902- } \\
\text { Annotated } \\
\text { Information } \\
\text { Value }\end{array}$ \\
\hline $\begin{array}{c}\text { Field: } \\
\text { 14.903- } \\
\text { Device } \\
\text { Unique } \\
\text { Identifier } \\
\text { Value }\end{array}$ \\
\hline Field: \\
\hline
\end{tabular}

\begin{tabular}{|c|c|c|c|c|}
\hline $\begin{array}{l}8.14 .26 \\
\text { Table } 67\end{array}$ & $\begin{array}{l}\text { This field signifies that images captured } \\
\text { separately were stitched together to form } \\
\text { a single image. This field is mandatory if } \\
\text { an image has been stitched, and the value } \\
\text { shall be set to 'Y'. Otherwise, this field } \\
\text { shall not appear in the record. }\end{array}$ & & D & $\begin{array}{l}\text { 14.027-SIF } \\
\text { Conditional }\end{array}$ \\
\hline Table 67 & $\begin{array}{l}\text { Reserved for future useonly by } \\
\text { ANSI/NIST-ITL. }\end{array}$ & & - & $\begin{array}{c}14.028 \\
14.029 \\
\text { Reserved }\end{array}$ \\
\hline $\begin{array}{l}8.14 .27 \\
\text { Table } 67\end{array}$ & $\begin{array}{l}<\text { Table } 67 \text { lists the value constraints for } \\
\text { DMM.> }\end{array}$ & 1 & 0 & $\begin{array}{l}14.030- \\
\text { DMM }\end{array}$ \\
\hline $\begin{array}{l}8.14 .28 \\
\text { Table } 67\end{array}$ & $\begin{array}{l}<\text { Table } 67 \text { lists the value constraints for } \\
\text { FAP.> }\end{array}$ & 1 & 0 & 14.031-FAP \\
\hline Table 67 & $\begin{array}{l}\text { Reserved for future useonly by } \\
\text { ANSI/NIST-ITL. }\end{array}$ & & - & $\begin{array}{c}14.032 \text { to } \\
14.199 \\
\text { Reserved }\end{array}$ \\
\hline Table 67 & User Defined Fields & & - & $\begin{array}{c}14.200 \text { to } \\
14.900- \\
\text { User } \\
\text { Defined }\end{array}$ \\
\hline Table 67 & $\begin{array}{l}\text { Reserved for future useonly by } \\
\text { ANSI/NIST-ITL. }\end{array}$ & & - & $\begin{array}{l}\text { 14.901- } \\
\text { Reserved }\end{array}$ \\
\hline $\begin{array}{l}8.14 .30 \\
\text { Table } 67\end{array}$ & $\begin{array}{l}\text { This is an optional field, listing the } \\
\text { operations performed on the original } \\
\text { source in order to prepare it for inclusion } \\
\text { in a biometric record type. See Section } \\
\text { 7.4.1. }\end{array}$ & & 0 & $\begin{array}{l}\text { 14.902- } \\
\text { ANN-Value }\end{array}$ \\
\hline $\begin{array}{l}8.14 .31 \\
\text { Table } 67\end{array}$ & $\begin{array}{l}\text { This is an optional field. See Section } \\
\text { 7.7.1.1. }\end{array}$ & & 0 & $\begin{array}{l}\text { 14.903-DUI } \\
\text { Value }\end{array}$ \\
\hline
\end{tabular}

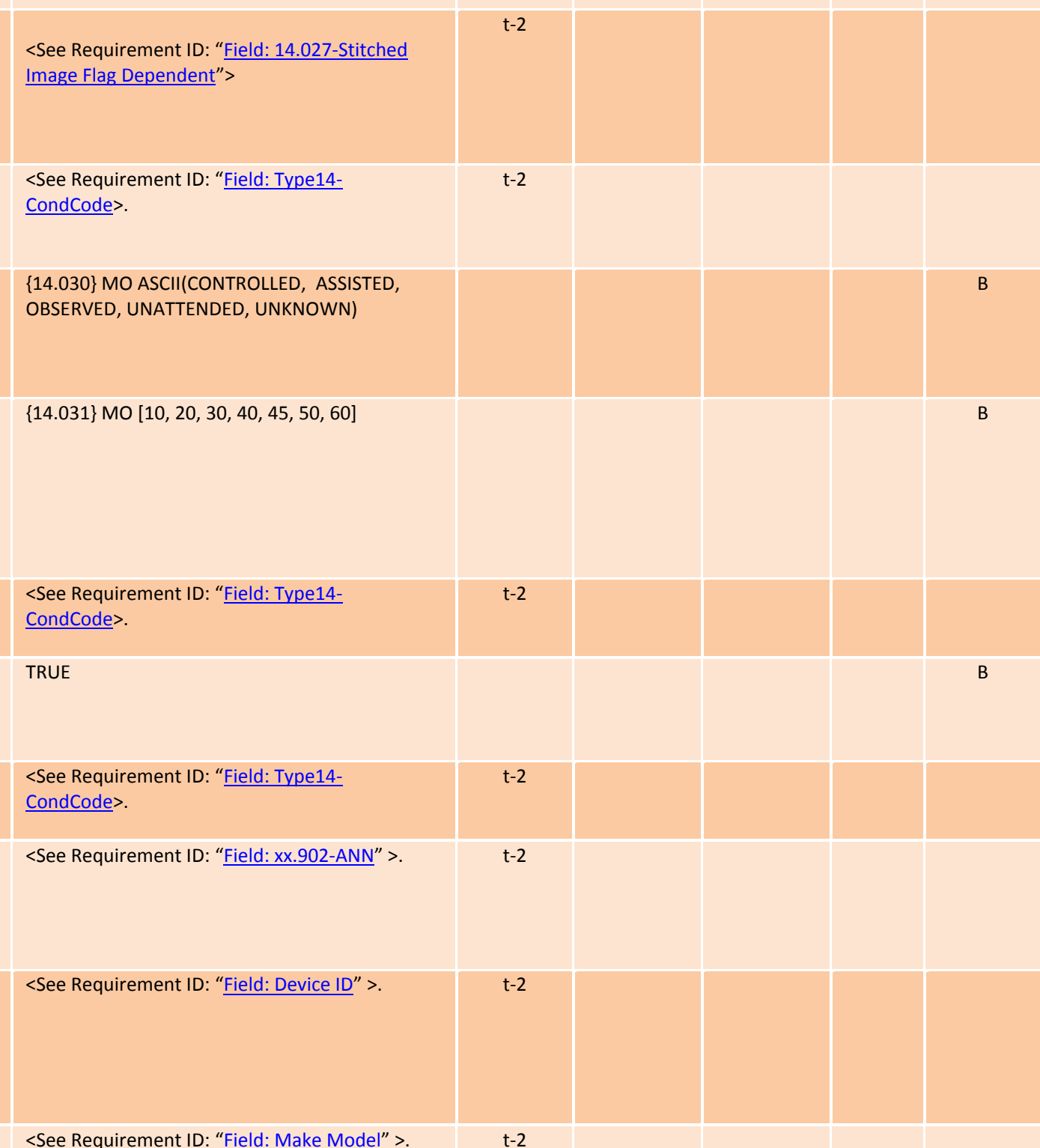




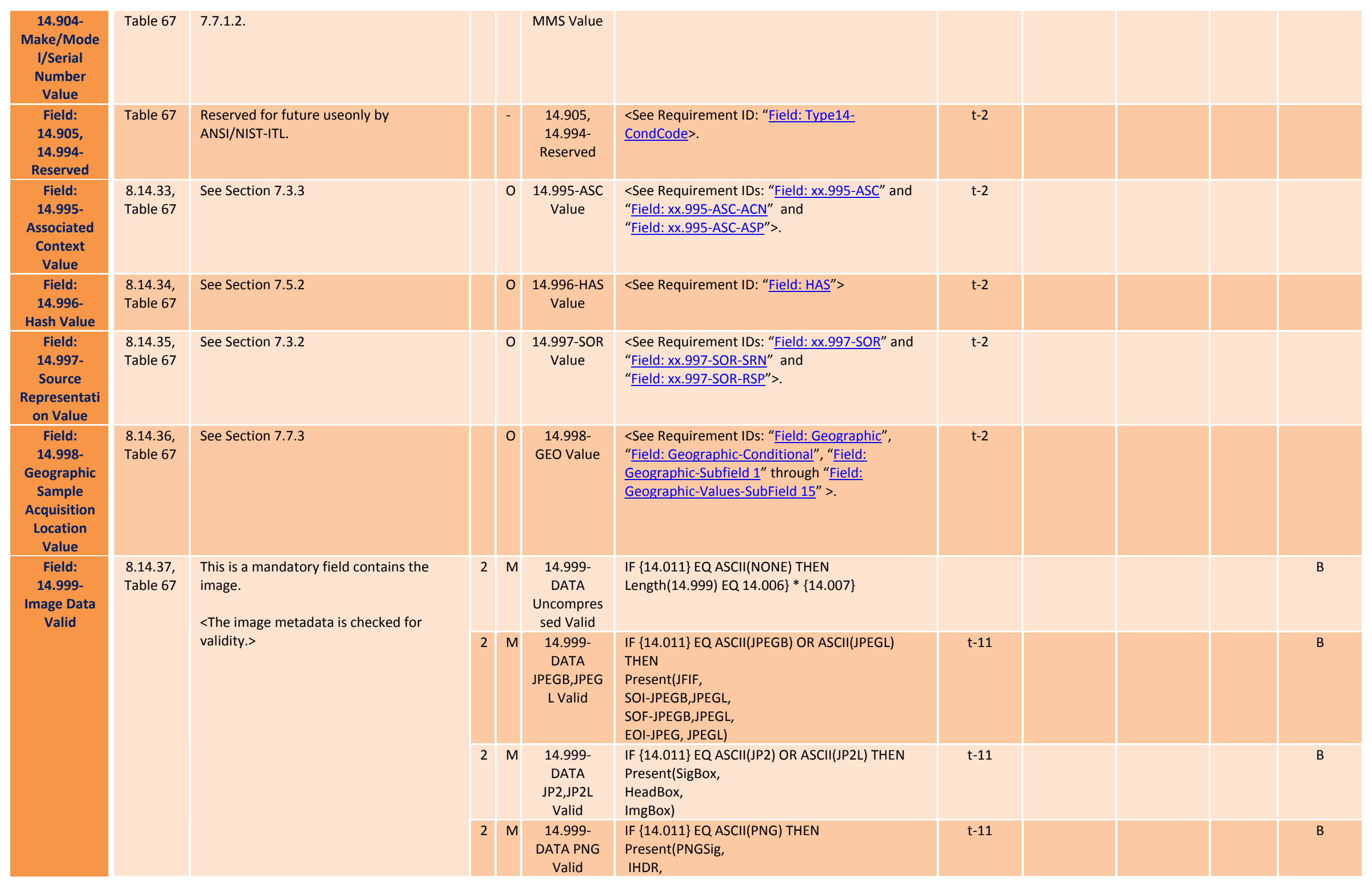



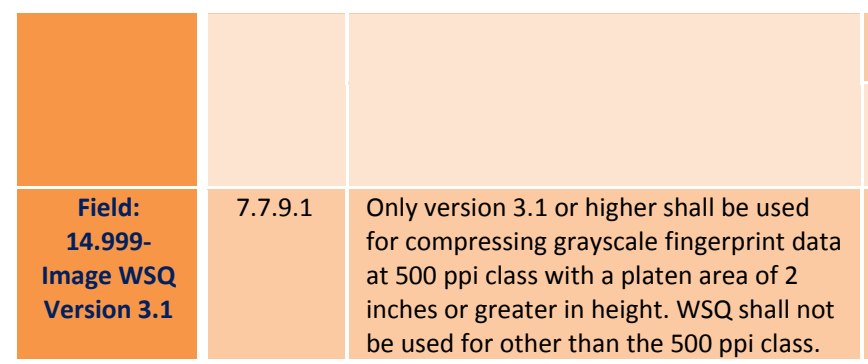

\begin{tabular}{|c|c|c|c|}
\hline 2 & M & $\begin{array}{c}14.999- \\
\text { DATA WSQ } \\
\text { Valid }\end{array}$ \\
\hline & M & $\begin{array}{c}\text { 14.999- } \\
\text { DATA WSQ } \\
\text { Version }\end{array}$ \\
\hline & & \\
\end{tabular}

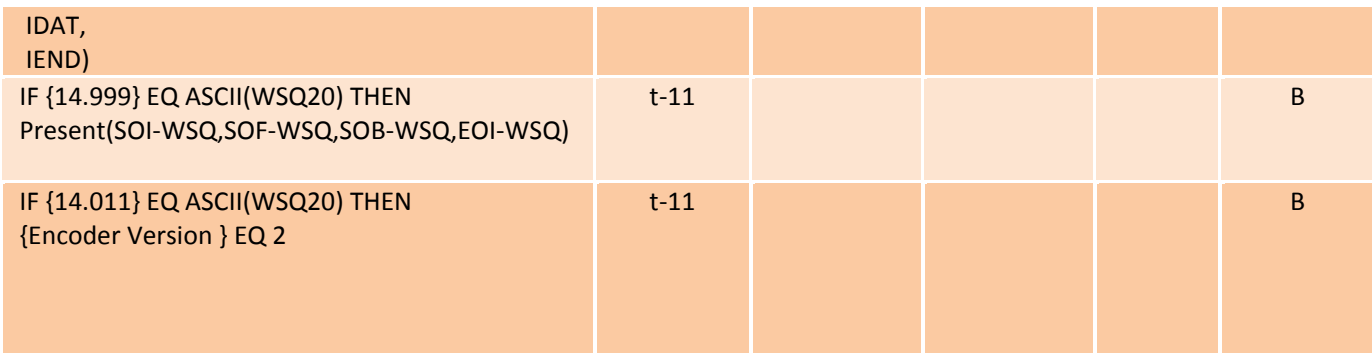

\section{Table C.14 - Assertions for Record Type 15 - Palm Print Image Record}

\begin{tabular}{|c|c|c|c|c|c|c|c|c|c|c|c|}
\hline $\begin{array}{l}\text { Requireme } \\
\text { nt } \\
\text { ID }\end{array}$ & $\begin{array}{l}\text { Referen } \\
\text { ce in } \\
\text { Base } \\
\text { Standar } \\
\quad \text { d }\end{array}$ & $\begin{array}{l}\text { Requirement } \\
\text { Summary }\end{array}$ & $\begin{array}{l}\text { L } \\
\text { e } \\
\text { v } \\
\text { e } \\
\text { I }\end{array}$ & $\begin{array}{l}\mathrm{S} \\
\mathrm{t} \\
\mathrm{a} \\
\mathrm{t} \\
\mathrm{u} \\
\mathrm{s}\end{array}$ & $\begin{array}{l}\text { Assertion } \\
\text { ID }\end{array}$ & $\begin{array}{l}\text { Test } \\
\text { Assertion }\end{array}$ & $\begin{array}{l}\text { Test } \\
\text { Note }\end{array}$ & $\begin{array}{l}\text { Implemen } \\
\text { tation } \\
\text { Support }\end{array}$ & $\begin{array}{c}\text { Supporte } \\
\text { d Range }\end{array}$ & $\begin{array}{c}\text { Test } \\
\text { Result }\end{array}$ & $\begin{array}{l}\text { Applicab } \\
\text { ility }\end{array}$ \\
\hline \multicolumn{12}{|c|}{ 8.15: Record Type-15: Palm print image record } \\
\hline $\begin{array}{l}\text { Record: } \\
\text { Type15- } \\
\text { Palm Print } \\
\text { Image }\end{array}$ & 8.15 & $\begin{array}{l}\text { The Type- } 15 \text { record shall contain and be } \\
\text { used to exchange palm print image data } \\
\text { together with fixed and user-defined } \\
\text { textual information fields pertinent to the } \\
\text { digitized image. } \\
\text { The image data shall be acquired directly } \\
\text { from a subject using a live-scan device, a } \\
\text { palmprint card, or other media that } \\
\text { contains the subject using a live-scan } \\
\text { device, aag }\end{array}$ & 3 & $M$ & $\begin{array}{l}\text { Type15- } \\
\text { Palm Print } \\
\text { Image }\end{array}$ & $\begin{array}{l}<\text { Not Tested. It is not feasible to test if the image } \\
\text { represents a palm print or how the image was } \\
\text { captured.> }\end{array}$ & $\mathrm{t}-1$ & & & & B \\
\hline $\begin{array}{l}\text { Record: } \\
\text { Type15- } \\
\text { Palm Print } \\
\text { Area }\end{array}$ & 8.15 & $\begin{array}{l}\text { Any method used to acquire the palm } \\
\text { print images shall be capable of capturing } \\
\text { a set of images for each hand. This set } \\
\text { may include the writerl be capable of } \\
\text { capturing a set of }\end{array}$ & 3 & $M$ & $\begin{array}{l}\text { Type15- } \\
\text { Palm Print } \\
\text { Area }\end{array}$ & $\begin{array}{l}<\text { Not Tested. It is not feasible to test which area } \\
\text { of the palm is represented in the image. }>\end{array}$ & $\mathrm{t}-1$ & & & & B \\
\hline
\end{tabular}




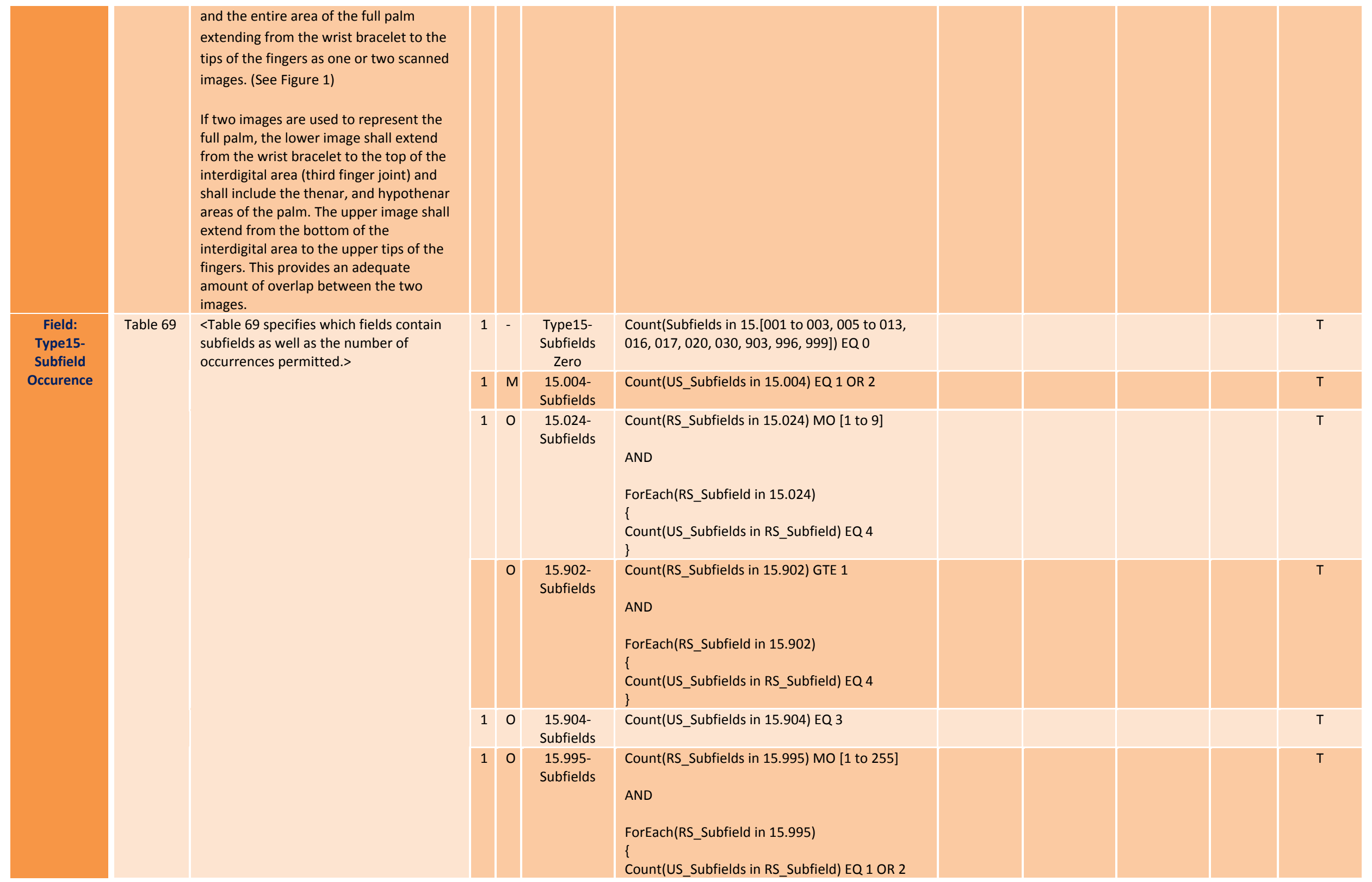




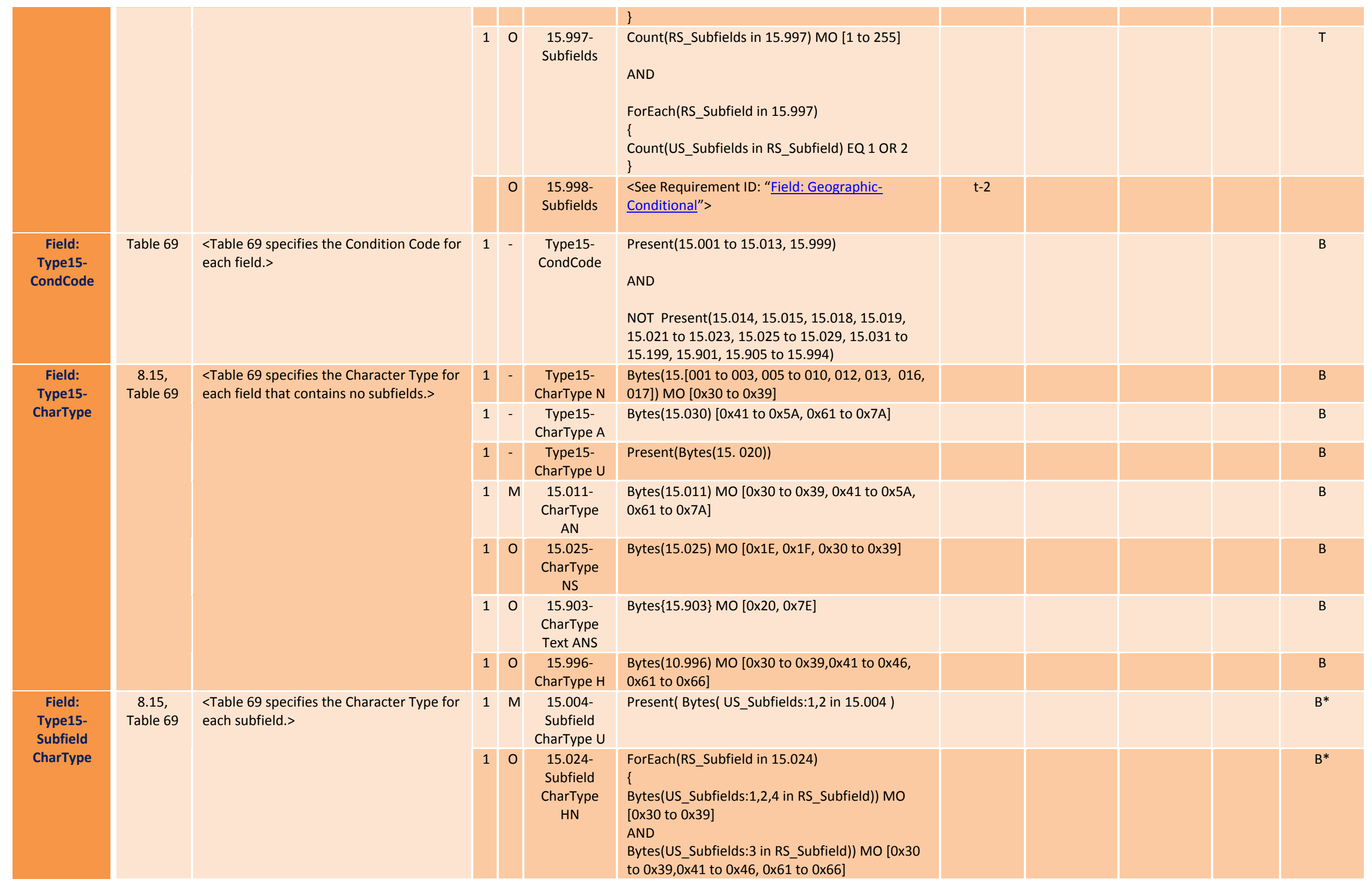



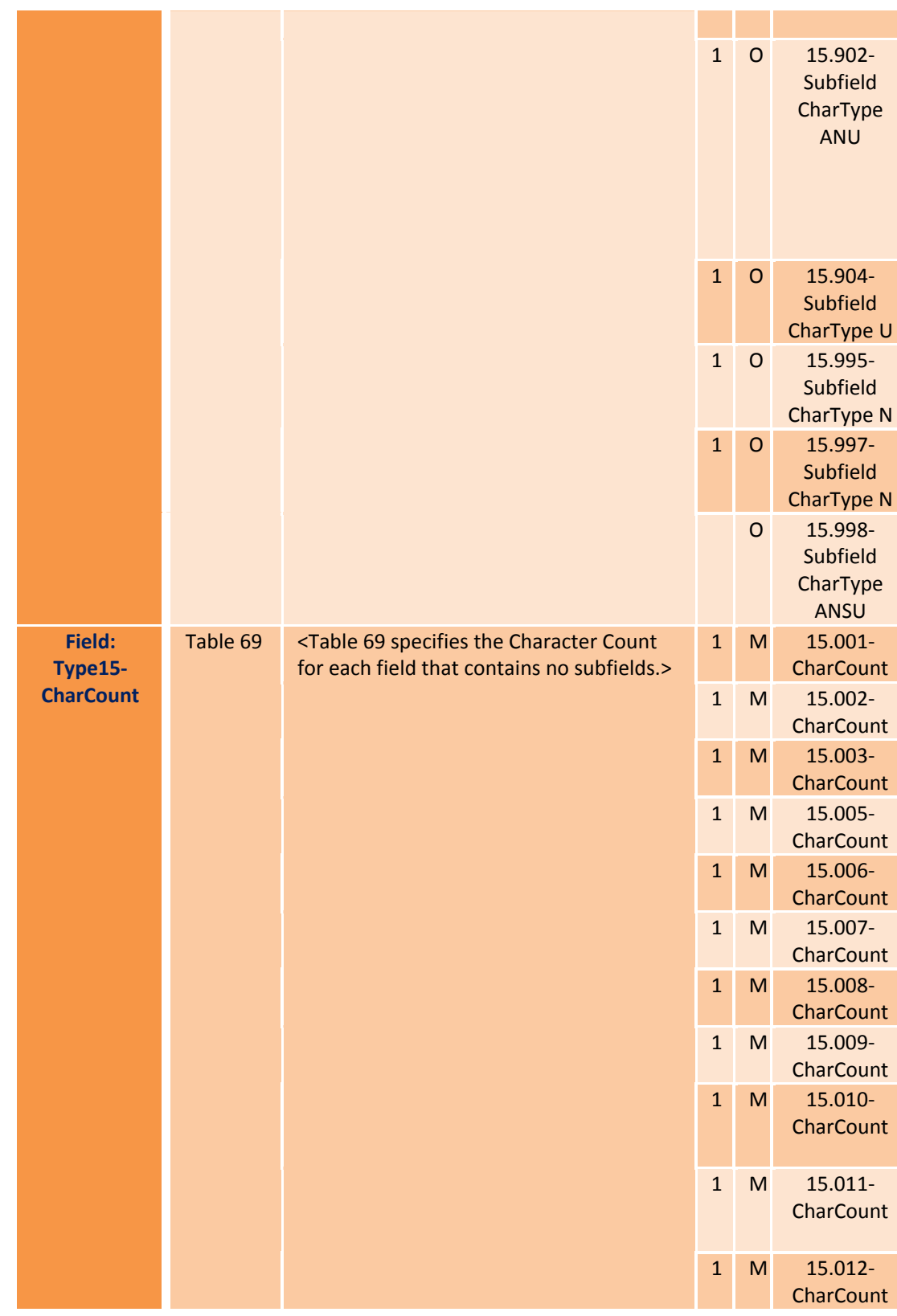

ForEach(RS_Subfield in 15.902)

(US Subfields: 2 to 4 in

RS_Subfield)

Bytes(US_Subfield:1 in RS_Subfield) MO [0×30 to $0 \times 39,0 \times 5 \mathrm{~A}]$

\begin{tabular}{|c|c|c|}
\hline 1 & 0 & $\begin{array}{c}15.904- \\
\text { Subfield } \\
\text { CharType U }\end{array}$ \\
\hline 1 & 0 & $15.995-$ \\
\hline
\end{tabular}

1 O $\begin{array}{ll}15.995- \\ \text { Subfield }\end{array}$ CharType N

$1 \quad 0 \quad 15.997-$ Subfield
CharType $\mathrm{N}$

O 15.998Subfield

CharType

Present(Bytes(All(US_Subfields in 15.904)))

Bytes(All(US_Subfields:1,2 in 15.995)) MO [0x30 to $0 \times 39$ ]

Bytes(All(US_Subfields:1,2 in 15.997)) MO [0x30 to $0 \times 39$ ]

<See Requirement ID: "Field: Geographic">

$\mathrm{t}-2$

1 M $\begin{gathered}15.001- \\ \text { CharCount }\end{gathered}$

1 M 15.002-

CharCount

1 M 15.003-

1 M 15.005CharCount

1 M 15.006-

1 M 15.007CharCount

1 M 15.008-

1 M 15.009CharCount

1 M 15.010CharCount

1 M 15.011-

DataLength(15.011) MO [3 to 5]

DataLength(15.001) GTE 1

DataLength(15.002) EQ 1 OR 2

DataLength(15.003) EQ 2

DataLength(15.005) EQ 8

DataLength(15.006) MO [2 to 5]

Datalength(15.007) MO [2 to 5]

DataLength(15.008) EQ 1

Datalength(15.009) MO [1 to 5]

DataLength(15.010) MO [1 to 5]

CharCount

1 M 15.012-

DataLength(15.012) EQ 1 OR 2 

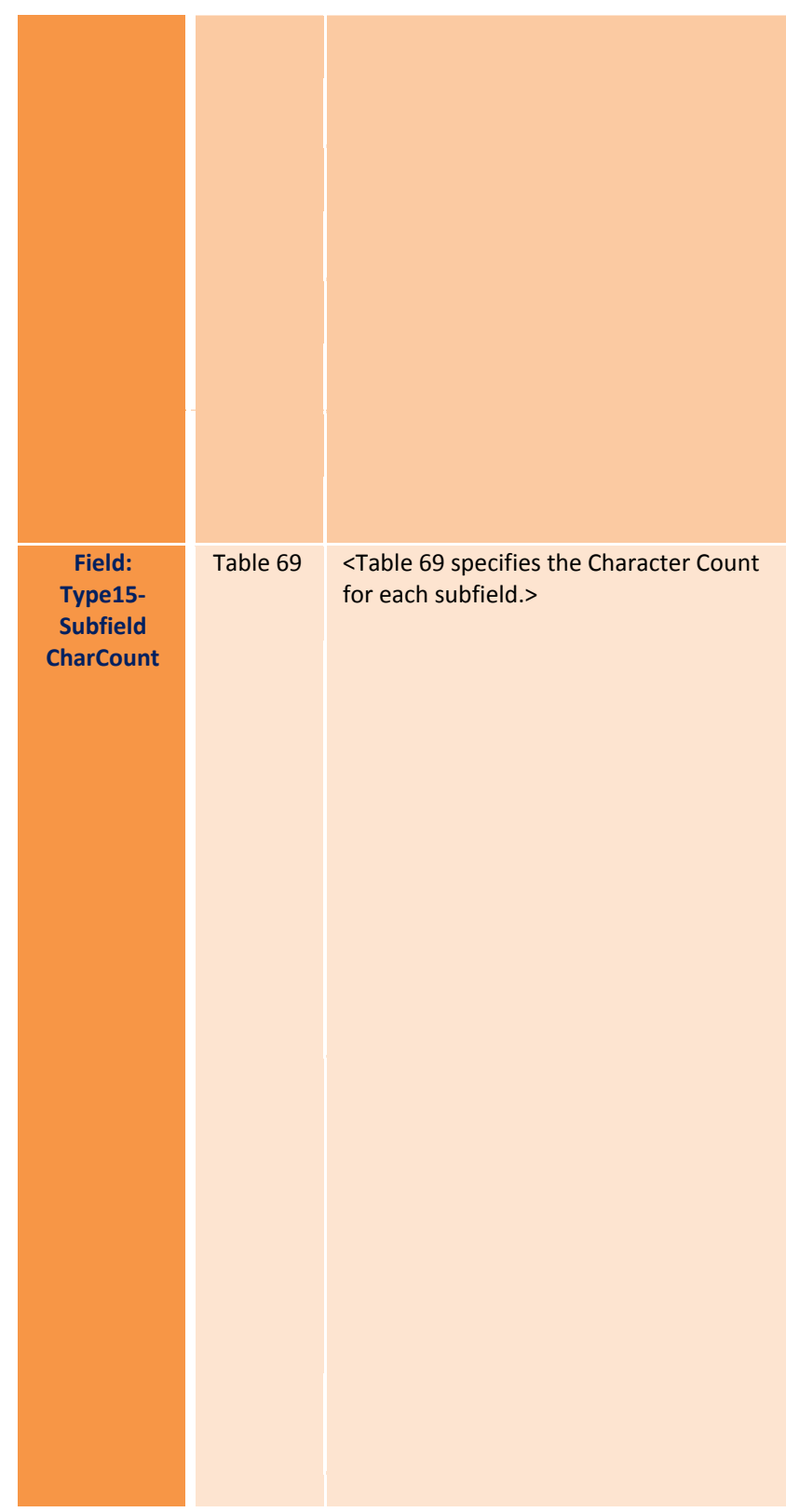

1 M 15.013CharCount

10 15.016-

10 15.017CharCount

10 15.020-

O 15.030 CharCount

10 15.903-

CharCount

1 M 15.999-

1 M 15.004CharCount

$1 \quad 0 \quad 15.024-$

Subfield

CharCount

Length

Length(US Subfields:2 in RS Subfield)) MO [1 to

3]

AND

Length(US_Subfields:3 in RS_Subfield)) EQ 4

AND

Length(US_Subfields:4 in RS_Subfield)) MO [1 to

5]

\}

$10 \quad 15.902-\quad$ ForEach(RS_Subfield in 15.902)

Subfield

CharCount

Len

AND

Length(US_Subfields:2,3 in RS_Subfield) MO [1

to 64

AND

Length(US_Subfield:4 in RS_Subfield)) MO [1 to 255]

1 O 15.904- Length(All(US_Subfields in 15.904)) MO [1 to 50]

Subfield

CharCount

10 15.995-

ForEach(RS_Subfield in 15.995)
B

B

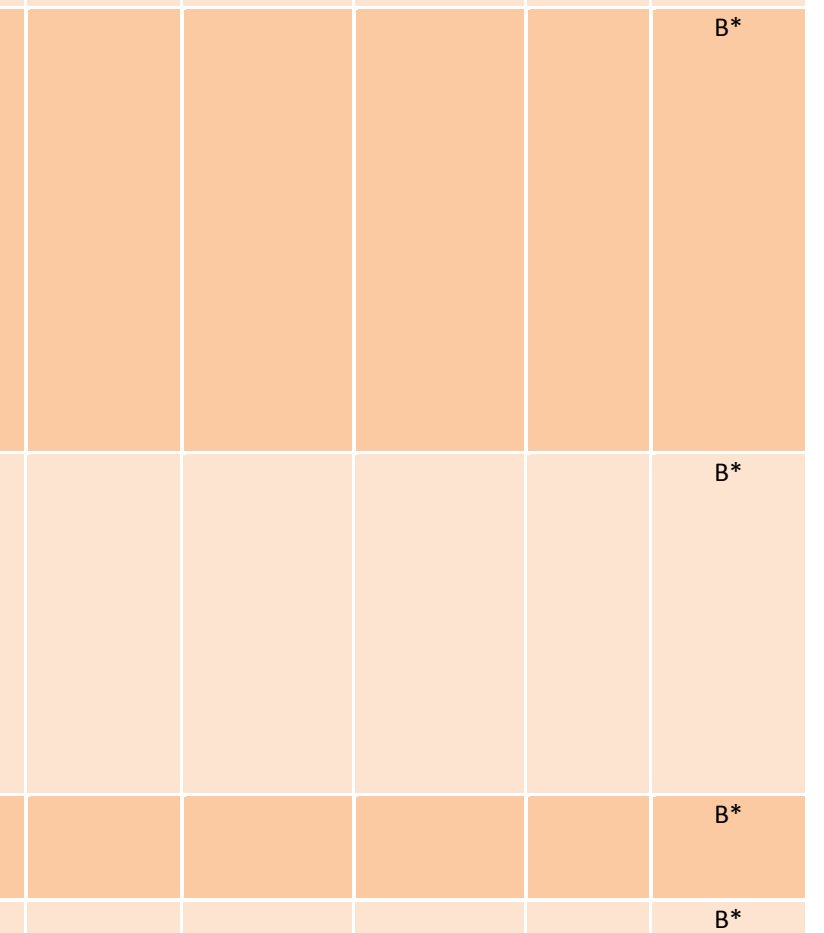




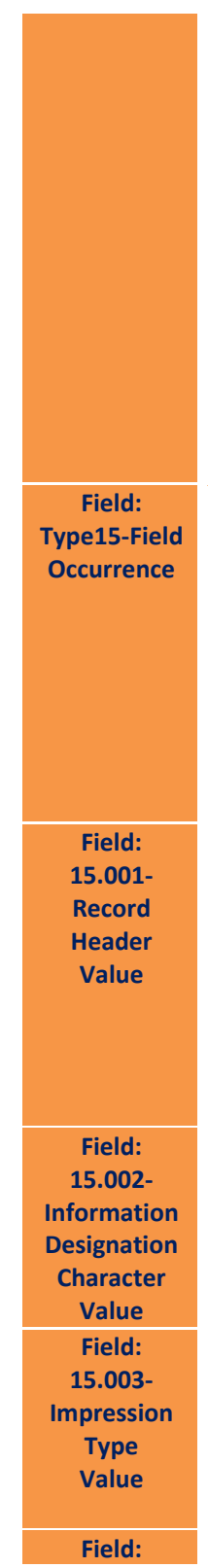

Table 69

$<$ Table 69 specifies the Field Occurrence for each field.>

8.15.1,

Field 15.001 Record header. In Traditional

Table 69, encoding, this field contains the record

7.1 length in bytes (including all information separators)

8.15.1, The XML name for the Type-15 record is

C.10.13 <itl:PackagePalmpprint/mageRecord>,

and its <biom:RecordCategoryCode>

element shall

have a value of " 15 ".

8.15.2, This mandatory field shall be the IDC of

Table 69, this Type-15 record as found in the

7.3.1 information item IDC of Field 1.003

Transaction content/CNT.

8.15.3, This mandatory field shall indicate the

Table 69, manner by which the latent print was

7.7.4.1, obtained.

Table 5 See Section 7.7.4.1 for details.

$<$ Table 69 lists the valid values for IMP.>

8.15.4, This is a mandatory field. See Section 7.6
Subfield

CharCount

- 1 (n)

\begin{tabular}{l|l|c|}
1 & 0 & $\begin{array}{c}15.997- \\
\text { Subfield }\end{array}$ \\
& & CharCount
\end{tabular}

CharCount

O 15.998-

Subfield

CharCount

1 - $\begin{gathered}\text { Type15- } \\ \text { Occurrence }\end{gathered}$

Zero

1 M Type15Occurrence One

1 - $\quad$ Type15- $\quad$ Count(15.[016, 017, 020, 024, 030, 902 to 904 ,

Occurrence

One or

Fewer

M 15.001-

Record

Header

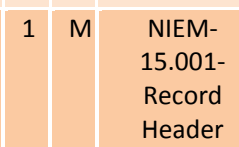

M 15.002-IDC

995 to 998$)$ LTE 1

$<$ See Requirement ID “Field: xx.001-Record

Header">

ForEach(XEIm(itl:PackagePalmprintImageRecord)

\{XEIm(biom:RecordCategoryCode) EQ ASCII(15) \}

<See Requirement IDs "Field: xx.002-IDC "and "Field: 1.003-Transaction Content Subfield 2 IDC Matches" >

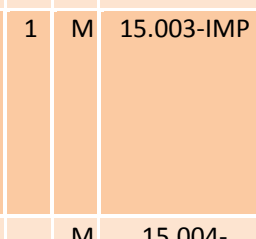

<See Requirement ID "Field: Agency Codes" > $\mathrm{t}-2$
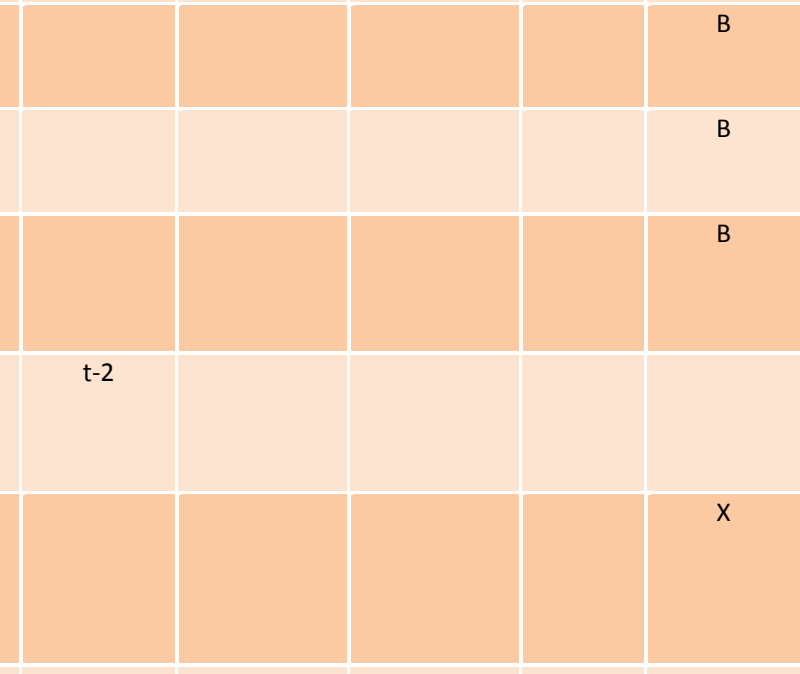

$\mathrm{t}-2$

B

$\mathrm{t}-2$ 


\begin{tabular}{|c|c|c|c|c|c|c|c|c|}
\hline $\begin{array}{l}\text { 15.004- } \\
\text { Originating } \\
\text { Agency } \\
\text { Value }\end{array}$ & 7.6 & for details. & & & ORG & & & \\
\hline \multirow[b]{2}{*}{$\begin{array}{l}\text { Field: } \\
\text { 15.005- } \\
\text { Palmprint } \\
\text { Capture } \\
\text { Date Value }\end{array}$} & \multirow{2}{*}{$\begin{array}{l}\text { 8.15.5 } \\
7.7 .2 .3\end{array}$} & \multirow{2}{*}{$\begin{array}{l}\text { This mandatory field shall contain the } \\
\text { date that the fingerprint data contained } \\
\text { in the record was captured. }\end{array}$} & 1 & M & 15.005-PCD & $\{15.005\}$ MO [ValidLocalDate] & $t-6$ & $\mathrm{~T}$ \\
\hline & & & 1 & M & $\begin{array}{l}\text { NIEM- } \\
15.005-P C D\end{array}$ & $\begin{array}{l}\text { ForEach(XEIm(itl:PackagePalmprintRecord)) } \\
\{ \\
\{\text { XEIm(nc:Date) in XEIm(biom:CaptureDate)\} MO } \\
\text { [NIEM-ValidLocalDate] } \\
\}\end{array}$ & $t-6$ & $x$ \\
\hline $\begin{array}{l}\text { Field: } \\
\text { 15.006- } \\
\text { Horizontal } \\
\text { Line Length } \\
\text { Value }\end{array}$ & $\begin{array}{c}\text { 8.15.6, } \\
\text { Table 69, } \\
7.7 .8 .1\end{array}$ & $\begin{array}{l}\text { The maximum horizontal size is limited to } \\
65,534 \text { pixels in Record Types- } 4 \text { and } 8 \text {, } \\
\text { and to } 99,999 \text { for other record types. The } \\
\text { minimum value is } 10 \text { pixels. }\end{array}$ & & M & 15.006-HLL & <See Requirement ID “Field: Image HLL Value” > & $t-2$ & \\
\hline \multirow{4}{*}{$\begin{array}{l}\text { Field: } \\
\text { 15.006- } \\
\text { Horizontal } \\
\text { Line Length } \\
\text { Metadata }\end{array}$} & \multirow[t]{4}{*}{$\begin{array}{c}\text { 8.15.6, } \\
\text { Table 69, } \\
7.7 .8 .1\end{array}$} & \multirow[t]{4}{*}{$\begin{array}{l}<\text { The HLL is verified by checking the image } \\
\text { metadata if compression is used.> }\end{array}$} & 2 & M & $\begin{array}{c}\text { 15.006-HLL } \\
\text { Metadata } \\
\text { JPEGB,JPEG } \\
\text { L }\end{array}$ & $\begin{array}{l}\text { IF }\{15.011\} \text { EQ ASCII(JPEGB) OR ASCII(JPEGL) } \\
\text { THEN } \\
\{15.006\} \text { EQ }\{\text { ImageWidth-JPEGB,JPEGL }\}\end{array}$ & $\mathrm{t}-11$ & B \\
\hline & & & 2 & M & $\begin{array}{l}\text { 15.006-HLL } \\
\text { Metadata } \\
\text { JP2,JP2L }\end{array}$ & $\begin{array}{l}\text { IF }\{15.011\} \text { EQ ASCII(JP2) OR ASCII(JP2L) THEN } \\
\{15.006\} \text { EQ }\{\text { ImageWidth-JP2,JP2L }\}\end{array}$ & $\mathrm{t}-11$ & B \\
\hline & & & 2 & M & $\begin{array}{l}\text { 15.006-HLL } \\
\text { Metadata } \\
\text { PNG }\end{array}$ & $\begin{array}{l}\text { IF }\{15.011\} \text { EQ ASCII(PNG) THEN } \\
\{15.006\} \text { EQ \{ImageWidth-PNG }\}\end{array}$ & $\mathrm{t}-11$ & B \\
\hline & & & 2 & M & $\begin{array}{l}\text { 15.006-HLL } \\
\text { Metadata } \\
\text { WSQ }\end{array}$ & $\begin{array}{l}\text { IF }\{15.011\} \text { EQ ASCII(WSQ20) THEN } \\
\{15.006\} \text { EQ \{ImageWidth-WSQ }\}\end{array}$ & $\mathrm{t}-11$ & B \\
\hline $\begin{array}{l}\text { Field: } \\
\text { 15.007- } \\
\text { Vertical Line } \\
\text { Length } \\
\text { Value }\end{array}$ & $\begin{array}{c}\text { 8.15.7, } \\
\text { Table 69, } \\
7.7 .8 .2\end{array}$ & $\begin{array}{l}\text { The maximum vertical size is limited to } \\
65,534 \text { pixels in Record Types- } 4 \text { and } 8 \text {, } \\
\text { and to } 99,999 \text { for other record types. } \\
\text { The minimum value is } 10 \text { pixels. }\end{array}$ & & M & 15.007-VLL & <See Requirement ID “Field: Image VLL Value” > & $t-2$ & \\
\hline \multirow[t]{4}{*}{$\begin{array}{l}\text { Field: } \\
\text { 15.007- } \\
\text { Vertical Line } \\
\text { Length } \\
\text { Metadata }\end{array}$} & \multirow[t]{4}{*}{$\begin{array}{l}\text { 8.15.7, } \\
\text { Table } 69 \\
\text { 7.7.8.2 }\end{array}$} & \multirow[t]{4}{*}{$\begin{array}{l}<\text { The VLL is verified by checking the image } \\
\text { metadata if compression is used.> }\end{array}$} & 2 & M & $\begin{array}{l}\text { 15.007-VLL } \\
\text { Metadata } \\
\text { JPEGB, } \\
\text { JPEGL }\end{array}$ & $\begin{array}{l}\text { IF }\{15.011\} \text { EQ ASCII(JPEGB) OR ASCII(JPEGL) } \\
\text { THEN } \\
\{15.007\} \text { EQ }\{\text { ImageHeight-JPEGB,JPEGL }\}\end{array}$ & $\mathrm{t}-11$ & B \\
\hline & & & 2 & M & $\begin{array}{l}\text { 15.007-VLL } \\
\text { Metadata } \\
\text { JP2, JP2L }\end{array}$ & $\begin{array}{l}\text { IF }\{15.011\} \text { EQ ASCII(JP2) OR ASCII(JP2L) THEN } \\
\{15.007\} \text { EQ }\{\text { ImageHeight-JP2,JP2L\} }\end{array}$ & $\mathrm{t}-11$ & B \\
\hline & & & 2 & M & $\begin{array}{l}\text { 15.007-VLL } \\
\text { Metadata } \\
\text { PNG }\end{array}$ & $\begin{array}{l}\text { IF }\{15.011\} \text { EQ ASCII(PNG) THEN } \\
\{15.007\} \text { EQ \{ImageHeight-PNG }\}\end{array}$ & $\mathrm{t}-11$ & B \\
\hline & & & 2 & $M$ & $\begin{array}{l}\text { 15.006-VLL } \\
\text { Metadata } \\
\text { WSQ }\end{array}$ & $\begin{array}{l}\text { IF }\{15.011\} \text { EQ ASCII(WSQ20) THEN } \\
\{15.007\} \text { EQ \{ImageHeight-WSO }\}\end{array}$ & $\mathrm{t}-11$ & B \\
\hline
\end{tabular}




\begin{tabular}{|c|c|c|c|c|c|c|c|c|}
\hline $\begin{array}{c}\text { Field: } \\
\text { 15.008-Scale } \\
\text { Units Value }\end{array}$ & $\begin{array}{c}\text { 8.15.8, } \\
\text { Table 69, } \\
\text { 7.7.8.3 }\end{array}$ & $\begin{array}{l}<\text { Table } 69 \text { lists the value constraints for } \\
\text { SLC }>\end{array}$ & & M & 15.008-SLC & <See Requirement ID “Field: Image SLC Value" > & $\mathrm{t}-2$ & \\
\hline \multirow[t]{4}{*}{$\begin{array}{l}\text { Field: } \\
\text { 15.008- } \\
\text { Scale Units } \\
\text { Metadata }\end{array}$} & \multirow[t]{4}{*}{$\begin{array}{c}\text { 8.15.8, } \\
\text { Table 69, } \\
\text { 7.7.8.3 }\end{array}$} & \multirow{4}{*}{$\begin{array}{l}\text { A value of " } 1 \text { " shall indicate pixels per } \\
\text { inch. } \\
\text { A value of " } 2 \text { " shall indicate pixels per } \\
\text { centimeter. A value of " } 0 \text { " in this field } \\
\text { indicates that no scale is provided, and } \\
\text { the quotient of THPS/TVPS shall provide } \\
\text { the pixel aspect ratio. } \\
<\text { The SLC is verified by checking the image } \\
\text { metadata if compression is used.> }\end{array}$} & 2 & M & $\begin{array}{l}\text { 15.008-SLC } \\
\text { Metadata } \\
\text { JPEGB,JPEG } \\
\text { L }\end{array}$ & $\begin{array}{l}\text { IF }\{15.011\} \text { EQ ASCII(JPEGB) OR ASCII(JPEGL) } \\
\text { THEN }\{15.008\} \text { EQ \{SamplingUnits-JPEGB,JPEGL\} }\end{array}$ & $\mathrm{t}-11$ & B \\
\hline & & & & & $\begin{array}{c}\text { 15.008-SLC } \\
\text { Metadata } \\
\text { JP2,JP2L }\end{array}$ & $<$ Not Tested. $>$ & $\mathrm{t}-12$ & B \\
\hline & & & 2 & M & $\begin{array}{c}\text { 15.008-SLC } \\
\text { Metadata } \\
\text { PNG }\end{array}$ & $\begin{array}{l}\text { IF }\{15.011\} \text { EQ ASCII(PNG) THEN } \\
\text { IF }\{15.008\} \text { EQ } 1 \text { OR } 2 \text { THEN \{ SamplingUnits- } \\
\text { PNG } \text { EQ 1, ELSE IF }\{15.008\} \text { EQ O THEN } \\
\text { SamplingUnits-PNG }\} \text { EQ } 0\end{array}$ & $\mathrm{t}-11$ & B \\
\hline & & & & & $\begin{array}{c}\text { 15.008-SLC } \\
\text { Metadata } \\
\text { WSQ }\end{array}$ & $<$ Not Tested.> & $\mathrm{t}-12$ & B \\
\hline $\begin{array}{c}\text { Field: } \\
\text { 15.009- } \\
\text { Transmitted } \\
\text { Horizontal } \\
\text { Pixel Scale } \\
\text { Value }\end{array}$ & $\begin{array}{c}\text { 8.15.9, } \\
\text { Table 69, } \\
\text { 7.7.8.4 }\end{array}$ & $\begin{array}{l}<\text { Table } 69 \text { lists the value constraints for } \\
\text { THPS.> }\end{array}$ & & M & $\begin{array}{l}15.009- \\
\text { THPS }\end{array}$ & $\begin{array}{l}<\text { See Requirement ID "Field: Image THPS Value" } \\
>\end{array}$ & $t-2$ & \\
\hline \multirow[t]{5}{*}{$\begin{array}{l}\text { Field: } \\
\text { 15.009- } \\
\text { Transmitted } \\
\text { Horizontal } \\
\text { Pixel Scale } \\
\text { Metadata }\end{array}$} & \multirow[t]{5}{*}{$\begin{array}{c}\text { 8.15.9, } \\
\text { Table 69, } \\
7.7 .8 .4\end{array}$} & \multirow{5}{*}{$\begin{array}{l}\text { This is the integer pixel density used in } \\
\text { the horizontal direction of the image if } \\
\text { SLC has a value of " } 1 \text { " or " } 2 \text { ". If SLC has a } \\
\text { value of " } 0 \text { ", this information item shall } \\
\text { contain the horizontal component of the } \\
\text { pixel aspect ratio, up to } 5 \text { digits. } \\
\text { <The THPS is verified by checking the } \\
\text { image metadata if compression is used.> }\end{array}$} & 2 & M & $\begin{array}{c}\text { 15.009- } \\
\text { THPS } \\
\text { Metadata } \\
\text { JPEGB,JPEG } \\
\text { L }\end{array}$ & $\begin{array}{l}\text { IF }\{15.011\} \text { EQ ASCII(JPEGB) OR ASCII(JPEGL) AND } \\
\{15.008\} \text { EQ } 1 \text { OR } 2 \\
\text { THEN }\{15.009\} \text { EQ }\{\text { HorizontalDensity- } \\
\text { JPEGB,JPEGL\} }\end{array}$ & $\mathrm{t}-11$ & B \\
\hline & & & & & $\begin{array}{l}\text { 15.009- } \\
\text { THPS } \\
\text { Metadata } \\
\text { JP2, JP2L }\end{array}$ & $<$ Not Tested. $>$ & $\mathrm{t}-12$ & B \\
\hline & & & 2 & M & $\begin{array}{l}\text { 15.009- } \\
\text { THPS } \\
\text { Metadata } \\
\text { PNG }\end{array}$ & $\begin{array}{l}\text { IF }\{15.011\} \text { EQ ASCII(PNG) AND }\{15.008\} \text { EQ } 1 \\
\text { THEN }\{15.009\} \text { EQ }\left\{\text { HorizontalDensity-PNG }{ }^{*}\right. \\
0.0254 \text { (meters/inch), } \\
\text { ELSE IF }\{15.011\} \text { EQ ASCII(PNG) AND }\{15.008\} \text { EQ } \\
2 \\
\text { THEN }\{15.009\} \text { EQ }\left\{\text { HorizontalDensity-PNG }{ }^{*}\right. \\
0.01 \text { (meters/cm) }\end{array}$ & $\mathrm{t}-11$ & B \\
\hline & & & & & $\begin{array}{l}\text { 15.009- } \\
\text { THPS } \\
\text { Metadata } \\
\text { WSQ }\end{array}$ & $<$ Not Tested.> & $\mathrm{t}-12$ & B \\
\hline & & & 2 & M & $\begin{array}{l}\text { 15.009- } \\
\text { THPS }\end{array}$ & $\begin{array}{l}\text { IF }\{15.011\} \text { EQ ASCII(JPEGB) OR ASCII(JPEGL) AND } \\
\{15.008\} \text { NEQ } 1 \text { OR } 2\end{array}$ & $\mathrm{t}-11$ & B \\
\hline
\end{tabular}




\begin{tabular}{|c|c|c|c|c|c|c|c|c|}
\hline & & & & & $\begin{array}{c}\text { Aspect } \\
\text { Ratio } \\
\text { Metadata } \\
\text { JPEGB,JPEG } \\
\text { L }\end{array}$ & $\begin{array}{l}\text { THEN }\{15.009\} /\{15.010\} \text { EQ }\{\text { HorizontalDensity- } \\
\text { JPEGB,JPEGL } /\{\text { VerticalDensity-JPEGB,JPEGL }\}\end{array}$ & & \\
\hline & & & & & $\begin{array}{l}\text { 15.009- } \\
\text { THPS } \\
\text { Aspect } \\
\text { Ratio } \\
\text { Metadata } \\
\text { JP2, JP2L }\end{array}$ & $<$ Not Tested. $>$ & $t-12$ & B \\
\hline & & & 2 & M & $\begin{array}{l}\text { 15.009- } \\
\text { THPS } \\
\text { Aspect } \\
\text { Ratio } \\
\text { Metadata } \\
\text { PNG }\end{array}$ & $\begin{array}{l}\text { IF }\{15.011\} \text { EQ ASCII(PNG) AND }\{15.008\} \text { NEQ } 1 \\
\text { OR } 2 \\
\text { THEN }\{15.009\} /\{15.010\} \text { EQ }\{\text { HorizontalDensity- } \\
\text { PNG } /\{\text { VerticalDensity-PNG }\}\end{array}$ & $t-11$ & B \\
\hline & & & & & $\begin{array}{l}\text { 15.009- } \\
\text { THPS } \\
\text { Aspect } \\
\text { Ratio } \\
\text { Metadata } \\
\text { WSQ }\end{array}$ & $<$ Not Tested. $>$ & $t-12$ & B \\
\hline $\begin{array}{c}\text { Field: } \\
\text { 15.010- } \\
\text { Transmitted } \\
\text { Vertical } \\
\text { Pixel Scale } \\
\text { Value }\end{array}$ & $\begin{array}{l}\text { 8.15.10, } \\
\text { Table 69, } \\
\text { 7.7.8.5 }\end{array}$ & $\begin{array}{l}\text { <Table } 69 \text { lists the value constraints for } \\
\text { TVPS.> }\end{array}$ & & M & $\begin{array}{l}\text { 15.010- } \\
\text { TVPS }\end{array}$ & $\begin{array}{l}<\text { See Requirement ID “Field: Image TVPS Value" } \\
>\end{array}$ & $t-2$ & \\
\hline \multirow[t]{3}{*}{$\begin{array}{c}\text { Field: } \\
\text { 15.010- } \\
\text { Transmitted } \\
\text { Vertical } \\
\text { Pixel Scale } \\
\text { Metadata }\end{array}$} & \multirow[t]{3}{*}{$\begin{array}{c}\text { 8.15.10, } \\
\text { Table 69, } \\
7.7 .8 .5\end{array}$} & \multirow{3}{*}{$\begin{array}{l}\text { This is the integer pixel density used in } \\
\text { the Vertical direction of the image if SLC } \\
\text { has a value of " } 1 \text { " or " } 2 \text { ". If SLC has a } \\
\text { value of "0", this information item shall } \\
\text { contain the Vertical component of the } \\
\text { pixel aspect ratio, up to } 5 \text { digits. } \\
\text { <The TVPS is verified by checking the } \\
\text { image metadata if compression is used.> }\end{array}$} & 2 & M & $\begin{array}{c}\text { 15.010- } \\
\text { TVPS } \\
\text { Metadata } \\
\text { JPEGB,JPEG } \\
\text { L }\end{array}$ & $\begin{array}{l}\text { IF }\{15.011\} \text { EQ ASCII(JPEGB) OR ASCII(JPEGL) AND } \\
\{15.008\} \text { EQ } 1 \text { OR } 2 \\
\text { THEN }\{15.010\} \text { EQ }\{\text { VerticalDensity-JPEGB,JPEGL }\}\end{array}$ & $t-11$ & B \\
\hline & & & & & $\begin{array}{l}\text { 15.010- } \\
\text { TVPS } \\
\text { Metadata } \\
\text { JP2, JP2L }\end{array}$ & $<$ Not Tested. $>$ & $t-12$ & B \\
\hline & & & 2 & M & $\begin{array}{l}\text { 15.010- } \\
\text { TVPS } \\
\text { Metadata } \\
\text { PNG }\end{array}$ & $\begin{array}{l}\text { IF }\{15.011\} \text { EQ ASCII(PNG) AND }\{15.008\} \text { EQ } 1 \\
\text { THEN }\{15.010\} \text { EQ }\{\text { VerticalDensity-PNG }\} \\
0.0254 \text { (meters/inch), } \\
\text { ELSE IF }\{15.011\} \text { EQ ASCII(PNG) AND }\{15.008\} \text { EQ } \\
2 \\
\text { THEN }\{15.010\} \text { EQ }\{\text { VerticalDensity-PNG }\} * 0.01 \\
\text { (meters/cm) }\end{array}$ & $t-11$ & B \\
\hline
\end{tabular}




\begin{tabular}{|c|c|c|c|c|c|c|c|c|}
\hline & & & & & $\begin{array}{l}\text { 15.010- } \\
\text { TVPS } \\
\text { Metadata } \\
\text { WSQ }\end{array}$ & $<$ Not Tested. $>$ & $\mathrm{t}-12$ & B \\
\hline & & & 2 & M & $\begin{array}{c}\text { 15.010- } \\
\text { TVPS } \\
\text { Aspect } \\
\text { Ratio } \\
\text { Metadata } \\
\text { JPEGB,JPEG } \\
\text { L }\end{array}$ & $\begin{array}{l}\text { IF }\{15.011\} \text { EQ ASCII(JPEGB) OR ASCII(JPEGL) AND } \\
\{15.008\} \text { NEQ } 1 \text { OR } 2 \\
\text { THEN }\{15.009\} /\{15.010\} \text { EQ \{HorizontalDensity- } \\
\text { JPEGB,JPEGL\} / \{VerticalDensity-JPEGB,JPEGL\} }\end{array}$ & $\mathrm{t}-11$ & B \\
\hline & & & & & $\begin{array}{c}\text { 15.010- } \\
\text { TVPS } \\
\text { Aspect } \\
\text { Ratio } \\
\text { Metadata } \\
\text { JP2, JP2L }\end{array}$ & $<$ Not Tested. $>$ & $\mathrm{t}-12$ & B \\
\hline & & & 2 & M & $\begin{array}{l}\text { 15.010- } \\
\text { TVPS } \\
\text { Aspect } \\
\text { Ratio } \\
\text { Metadata } \\
\text { PNG }\end{array}$ & $\begin{array}{l}\text { IF }\{15.011\} \text { EQ ASCII(PNG) AND }\{15.008\} \text { NEQ } 1 \\
\text { OR } 2 \\
\text { THEN }\{15.009\} /\{15.010\} \text { EQ }\{\text { HorizontalDensity - } \\
\text { PNG } /\{\text { VerticalDensity-PNG }\}\end{array}$ & $\mathrm{t}-11$ & B \\
\hline & & & & & $\begin{array}{c}\text { 15.010- } \\
\text { TVPS } \\
\text { Aspect } \\
\text { Ratio } \\
\text { Metadata } \\
\text { WSQ }\end{array}$ & $<$ Not Tested. $>$ & $\mathrm{t}-12$ & B \\
\hline $\begin{array}{l}\text { Field: } \\
\text { 15.011- } \\
\text { Compressio } \\
\text { n Algorithm } \\
\text { Value }\end{array}$ & $\begin{array}{l}\text { 8.15.11, } \\
\text { Table 69, } \\
\text { 7.7.9.1 }\end{array}$ & $\begin{array}{l}\text { For each of these fields, the entry } \\
\text { corresponds to the appropriate Label } \\
\text { entry in Table 12: Field 15.011: } \\
\text { Compression algorithm / CGA. }\end{array}$ & 1 & M & 15.011-CGA & $\begin{array}{l}\{15.011\} \mathrm{MO}[\mathrm{ASCII}(\mathrm{NONE}, \mathrm{JPEGB}, \mathrm{JPEGL}, \mathrm{JP2} \\
\text { JP2L, PNG, WSQ)] }\end{array}$ & $\mathrm{t}-98$ & B \\
\hline \multirow[t]{4}{*}{$\begin{array}{c}\text { Field: } \\
\text { 15.011- } \\
\text { Compressio } \\
\text { n Algorithm } \\
\text { Metadata }\end{array}$} & \multirow[t]{4}{*}{$\begin{array}{l}\text { 8.15.11, } \\
\text { Table } 69\end{array}$} & \multirow[t]{4}{*}{$\begin{array}{l}<\text { The CGA is verified by checking the } \\
\text { image metadata for the compression type } \\
\text { signature if compression is used.> }\end{array}$} & 2 & M & $\begin{array}{c}15.011- \\
\text { CGAMetad } \\
\text { ata } \\
\text { JPEGB,JPEG } \\
\text { L }\end{array}$ & $\begin{array}{l}\text { IF }\{15.011\} \text { EQ ASCII(JPEGB) OR ASCII(JPEGL) } \\
\text { THEN } \\
\text { Present(SOI -JPEG,JPEGL) }\end{array}$ & $\mathrm{t}-11$ & B \\
\hline & & & 2 & M & $\begin{array}{l}\text { 15.011-CGA } \\
\text { Metadata } \\
\text { JP2, JP2L }\end{array}$ & $\begin{array}{l}\text { IF }\{15.011\} \text { EQ ASCII(JP2) OR ASCII(JP2L) THEN } \\
\text { Present(SigBox) }\end{array}$ & $\mathrm{t}-11$ & B \\
\hline & & & 2 & M & $\begin{array}{l}\text { 15.011-CGA } \\
\text { Metadata } \\
\text { PNG }\end{array}$ & $\begin{array}{l}\text { IF }\{15.011\} \text { EQ ASCII(PNG) THEN } \\
\text { Present(PNGSig) }\end{array}$ & $\mathrm{t}-11$ & B \\
\hline & & & 2 & M & 15.011-CGA & IF $\{15.011\}$ EQ ASCII(WSQ20) THEN & $t-11$ & B \\
\hline
\end{tabular}




\begin{tabular}{|c|c|c|c|c|c|c|c|c|}
\hline & & & & & $\begin{array}{l}\text { Metadata } \\
\text { WSQ }\end{array}$ & Present(SOI-WSQ) & & \\
\hline $\begin{array}{l}\text { Field: } \\
\text { 15.012-Bits } \\
\text { Per Pixel } \\
\text { Value }\end{array}$ & $\begin{array}{c}\text { 8.15.12, } \\
\text { Table 69, } \\
\text { 7.7.8.6 }\end{array}$ & $\begin{array}{l}\text { This field shall contain an entry of " } 8 \text { " for } \\
\text { normal grayscale values of "0" to " } 255 \text { ". } \\
\text { Any entry in this field greater than " } 8 \text { " } \\
\text { shall represent a grayscale pixel with } \\
\text { increased proportion. }\end{array}$ & & M & 15.012-BPX & <See Requirement ID “Field: Image BPX Value” > & $\mathrm{t}-2$ & \\
\hline \multirow[t]{4}{*}{$\begin{array}{l}\text { Field: } \\
\text { 15.012- Bits } \\
\text { Per Pixel } \\
\text { Metadata }\end{array}$} & \multirow[t]{4}{*}{$\begin{array}{l}8.15 .12 \\
\text { Table } 69\end{array}$} & \multirow[t]{4}{*}{$\begin{array}{l}<\text { The BPX is verified by checking the } \\
\text { image metadata for the compression type } \\
\text { signature if compression is used.> }\end{array}$} & 2 & M & $\begin{array}{l}\text { 15.012-BPX } \\
\text { Metadata } \\
\text { JPEGB,JPEG } \\
\text { L }\end{array}$ & $\{15.012\}$ EQ $\{$ BPX-JPEG, JPEGL $\}$ & $t-11$ & B \\
\hline & & & 2 & M & $\begin{array}{c}\text { 15.012-BPX } \\
\text { Metadata } \\
\text { JP2, JP2L }\end{array}$ & $\{15.012\}$ EQ $\{$ BPX-JP2,JP2L $\}$ & $t-11$ & B \\
\hline & & & 2 & M & $\begin{array}{c}\text { 15.012-BPX } \\
\text { Metadata } \\
\text { PNG }\end{array}$ & $\{15.012\}$ EQ $\{B P X-P N G\}$ & $t-11$ & B \\
\hline & & & & & $\begin{array}{c}\text { 15.012-BPX } \\
\text { Metadata } \\
\text { WSQ }\end{array}$ & $<$ Not Tested. $>$ & $t-12$ & B \\
\hline $\begin{array}{l}\text { Field: } \\
\text { 15.013- } \\
\text { Friction } \\
\text { Ridge } \\
\text { Generalized } \\
\text { Position } \\
\text { Value }\end{array}$ & $\begin{array}{l}\text { 8.15.13, } \\
\text { Table 69, } \\
\text { 7.7.4.2, } \\
\text { Table } 6\end{array}$ & See Section 7.7.4.2 for details. & 1 & M & $\begin{array}{l}\text { 15.013-FGP } \\
\text { Value }\end{array}$ & $\{15.013\} \mathrm{MO}[20$ to 38,81 to 84$]$ & & B \\
\hline $\begin{array}{l}\text { Field: } \\
\text { 15.014, } \\
\text { 15.015- } \\
\text { Reserved }\end{array}$ & Table 69 & $\begin{array}{l}\text { Reserved for future useonly by } \\
\text { ANSI/NIST-ITL. }\end{array}$ & & - & $\begin{array}{c}15.014 \\
15.015 \\
\text { Reserved }\end{array}$ & $\begin{array}{l}\text { <See Requirement ID: "Field: Type15- } \\
\text { CondCode>. }\end{array}$ & $\mathrm{t}-2$ & \\
\hline $\begin{array}{l}\text { Field: } \\
\text { 15.016- } \\
\text { Scanned } \\
\text { Horizontal } \\
\text { Pixel Scale } \\
\quad \text { Value }\end{array}$ & $\begin{array}{c}\text { 8.15.14, } \\
\text { Table 69, } \\
\text { 7.7.8.7 }\end{array}$ & See section 7.7 .8 for details. & & 0 & $\begin{array}{l}15.016- \\
\text { SHPS Value }\end{array}$ & $\begin{array}{l}\text { <See Requirement IDs: "Field: Image SHPS } \\
\underline{\text { Value" }}\end{array}$ & $\mathrm{t}-2$ & \\
\hline $\begin{array}{l}\text { Field: } \\
\text { 15.017- } \\
\text { Scanned } \\
\text { Vertical } \\
\text { Pixel Scale } \\
\text { Value }\end{array}$ & $\begin{array}{c}\text { 8.15.15, } \\
\text { Table 69, } \\
7.7 .8 .8\end{array}$ & See section 7.7 .8 for details. & & 0 & $\begin{array}{l}15.016- \\
\text { SVPS Value }\end{array}$ & $\begin{array}{l}\text { <See Requirement IDs: "Field: Image SVPS } \\
\text { Value"> }\end{array}$ & $\mathrm{t}-2$ & \\
\hline $\begin{array}{l}\text { Field: } \\
15.018, \\
15.019-\end{array}$ & Table 69 & $\begin{array}{l}\text { Reserved for future useonly by } \\
\text { ANSI/NIST-ITL. }\end{array}$ & & - & $\begin{array}{c}15.018 \\
15.019 \\
\text { Reserved }\end{array}$ & $\begin{array}{l}\text { <See Requirement ID: "Field: Type15- } \\
\text { CondCode>. }\end{array}$ & $\mathrm{t}-2$ & \\
\hline
\end{tabular}




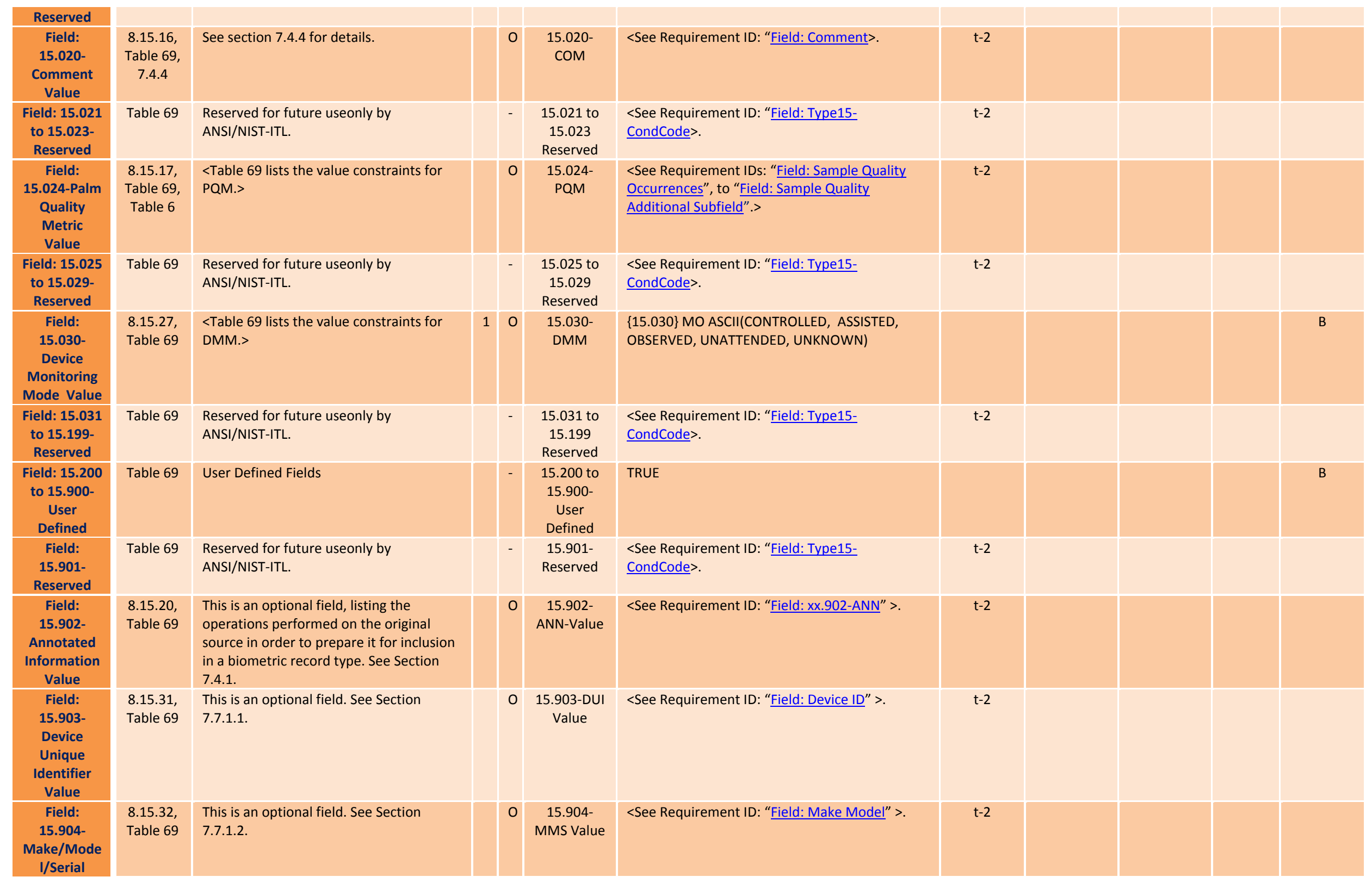




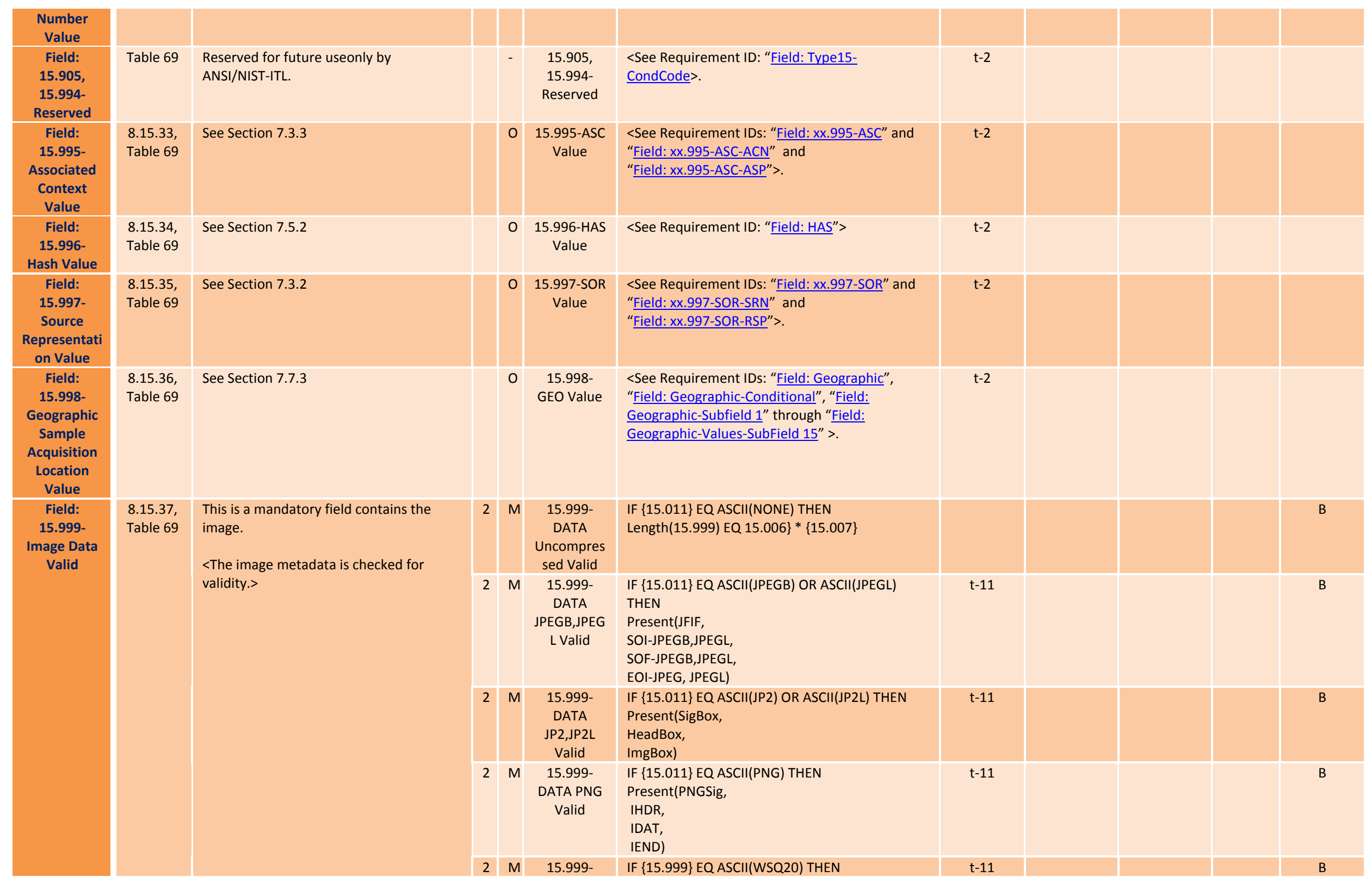




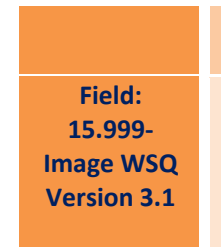

7.7.9.1

Only version 3.1 or higher shall be used

for compressing grayscale fingerprint data

at 500 ppi class with a platen area of 2

inches or greater in height. WSQ shall not

be used for other than the 500 ppi class.
DATA WSQ Present(SOI-WSO,SOF-WSQ,SOB-WSO,EOI-WSO)

Valid

2 M 15.999-

DATA WSQ

IF $\{15.011\}$ EQ ASCII(WSQ20) THEN

\{Encoder Version \} EQ 2

Version 
Table C.15 - Assertions for Record Type 17 - Iris Image Record

\begin{tabular}{|c|c|c|c|c|c|c|c|c|c|c|c|}
\hline $\begin{array}{l}\text { Requireme } \\
\text { nt } \\
\text { ID }\end{array}$ & $\begin{array}{l}\text { Referen } \\
\text { ce in } \\
\text { Base } \\
\text { Standar } \\
\quad \text { d }\end{array}$ & $\begin{array}{l}\text { Requirement } \\
\text { Summary }\end{array}$ & $\begin{array}{l}\text { L } \\
\text { e } \\
\text { v } \\
\text { e } \\
\text { I }\end{array}$ & $\begin{array}{l}\mathrm{S} \\
\mathrm{t} \\
\mathrm{a} \\
\mathrm{t} \\
\mathrm{u} \\
\mathrm{s}\end{array}$ & $\begin{array}{l}\text { Assertion } \\
\text { ID }\end{array}$ & $\begin{array}{l}\text { Test } \\
\text { Assertion }\end{array}$ & $\begin{array}{l}\text { Test } \\
\text { Note }\end{array}$ & $\begin{array}{l}\text { Implemen } \\
\text { tation } \\
\text { Support }\end{array}$ & $\begin{array}{l}\text { Supporte } \\
\text { d Range }\end{array}$ & $\begin{array}{l}\text { Test } \\
\text { Result }\end{array}$ & $\begin{array}{l}\text { Applicab } \\
\text { ility }\end{array}$ \\
\hline \multicolumn{12}{|c|}{ 8.17: Record Type-17: Iris image record } \\
\hline \multirow{11}{*}{$\begin{array}{l}\text { Field: } \\
\text { Type17- } \\
\text { Subfield } \\
\text { Occurrence }\end{array}$} & \multirow[t]{11}{*}{ Table 71} & \multirow[t]{11}{*}{$\begin{array}{l}<\text { Table } 71 \text { specifies which fields contain } \\
\text { subfields as well as the number of } \\
\text { occurrences permitted.> }\end{array}$} & 1 & - & $\begin{array}{l}\text { Type17- } \\
\text { Subfields } \\
\text { Zero }\end{array}$ & $\begin{array}{l}\text { Count(Subfields in } 17 .[001 \text { to } 003,005 \text { to } 015 \text {, } \\
017,020 \text { to } 023,026,030 \text { to } 032,040,041,996] \text { ) } \\
\text { EQ } 0\end{array}$ & & & & & $\mathrm{~T}$ \\
\hline & & & 1 & M & $\begin{array}{l}17.004- \\
\text { Subfields }\end{array}$ & Count(US_Subfields in 17.004) EQ 1 OR 2 & & & & & $\mathrm{~T}$ \\
\hline & & & 1 & 0 & $\begin{array}{l}\text { 17.016- } \\
\text { Subfields }\end{array}$ & Count(US_Subfields in 17.016) EQ 3 & & & & & $\mathrm{~T}$ \\
\hline & & & 1 & 0 & $\begin{array}{l}\text { 17.019- } \\
\text { Subfields }\end{array}$ & Count(US_Subfields in 17.019) EQ 3 & & & & & $\mathrm{~T}$ \\
\hline & & & 1 & 0 & $\begin{array}{l}17.024- \\
\text { Subfields }\end{array}$ & $\begin{array}{l}\text { Count(RS_Subfields in 17.024) MO [1 to 9] } \\
\text { AND } \\
\text { ForEach(RS_Subfield in 17.024) } \\
\{ \\
\text { Count(US_Subfields in RS_Subfield) EQ } 3 \\
\}\end{array}$ & & & & & $\mathrm{T}$ \\
\hline & & & 1 & M & $\begin{array}{l}17.025- \\
\text { Subfields }\end{array}$ & $\begin{array}{l}\text { IF \{US_Subfield:1 in } 17.025\} \text { EQ ASCII(DEFINED) } \\
\text { THEN } \\
\text { Count(US_Subfields in 17.025) EQ } 3 \\
\text { ELSE } \\
\text { Count(US_Subfields in 17.025) EQ } 1 \\
\}\end{array}$ & & & & & $\mathrm{T}$ \\
\hline & & & 1 & 0 & $\begin{array}{l}\text { 17.033- } \\
\text { Subfields }\end{array}$ & $\begin{array}{l}\text { Count(US_Subfields in 17.033) EQ } 2+ \\
2^{*}\{\text { US_Subfield:2 in } 17.033\} \\
\}\end{array}$ & & & & & $\mathrm{T}$ \\
\hline & & & 1 & 0 & $\begin{array}{l}17.034- \\
\text { Subfields }\end{array}$ & $\begin{array}{l}\text { Count(US_Subfields in 17.034) EQ } 2+ \\
2 *\{\text { US_Subfield: } 2 \text { in } 17.034\} \\
\}\end{array}$ & & & & & $\mathrm{T}$ \\
\hline & & & 1 & 0 & $\begin{array}{l}\text { 17.035- } \\
\text { Subfields }\end{array}$ & $\begin{array}{l}\text { Count(US_Subfields in 17.035) EQ } 2+2 *\{ \\
\text { US_Subfield: } 2 \text { in } 17.035\} \\
\}\end{array}$ & & & & & $\mathrm{T}$ \\
\hline & & & 1 & 0 & $\begin{array}{l}17.036- \\
\text { Subfields }\end{array}$ & $\begin{array}{l}\text { Count(US_Subfields in 17.036) EQ } 2+2 *\{ \\
\text { US_Subfield: } 2 \text { in } 17.036\} \\
\}\end{array}$ & & & & & $\mathrm{T}$ \\
\hline & & & 1 & 0 & 17.037- & Count(US_Subfields in 17.037) EQ $3+$ & & & & & $\mathrm{T}$ \\
\hline
\end{tabular}




\begin{tabular}{|c|c|c|c|c|c|c|c|c|}
\hline & & & & & Subfields & $\begin{array}{l}2 *\{\text { US_Subfield: } 3 \text { in } 17.037)\} \\
\}\end{array}$ & & \\
\hline & & & 1 & 0 & $\begin{array}{l}17.902- \\
\text { Subfields }\end{array}$ & $\begin{array}{l}\text { Count(RS_Subfields in 17.902) GTE } 1 \\
\text { AND } \\
\text { ForEach(RS_Subfield in 17.902) } \\
\{ \\
\text { Count(US_Subfields in RS_Subfield) EQ } 4 \\
\}\end{array}$ & & $\mathrm{T}$ \\
\hline & & & 1 & 0 & $\begin{array}{l}17.995- \\
\text { Subfields }\end{array}$ & $\begin{array}{l}\text { Count(RS_Subfields in 17.995) MO [1 to 255] } \\
\text { AND } \\
\text { ForEach(RS_Subfield in 17.995) } \\
\{ \\
\text { Count(US_Subfields in RS_Subfield) EQ 2OR } 3 \\
\text { \} }\end{array}$ & & $\mathrm{T}$ \\
\hline & & & 1 & $\mathrm{O}$ & $\begin{array}{l}\text { 17.997- } \\
\text { Subfields }\end{array}$ & $\begin{array}{l}\text { Count(RS_Subfields in 17.997) MO [1 to 255] } \\
\text { AND } \\
\text { ForEach(RS_Subfield in 17.997) } \\
\left\{\begin{array}{l}\text { Count(US_Subfields in RS_Subfield) EQ } 1 \text { OR } 2 \\
\}\end{array}\right.\end{array}$ & & $\mathrm{T}$ \\
\hline & & & & $\mathrm{O}$ & $\begin{array}{l}17.998- \\
\text { Subfields }\end{array}$ & $\begin{array}{l}\text { <See Requirement ID: "Field: Geographic- } \\
\text { Conditional"> }\end{array}$ & $\mathrm{t}-2$ & \\
\hline $\begin{array}{l}\text { Field: } \\
\text { Type17- } \\
\text { CondCode }\end{array}$ & Table 71 & $\begin{array}{l}<\text { Table } 71 \text { specifies the Condition Code for } \\
\text { each field.> }\end{array}$ & 1 & - & $\begin{array}{l}\text { Type17- } \\
\text { CondCode }\end{array}$ & $\begin{array}{l}\text { Present(17.001 to } 17.013,17.025,17.032 \text {, } \\
17.999) \\
\text { AND } \\
\text { NOT Present(17.018, } 17.027 \text { to } 17.029,17.038 \text {, } \\
17.039,17.042 \text { to } 17.199,17.901,17.903 \text { to } \\
17.994)\end{array}$ & & B \\
\hline $\begin{array}{l}\text { Field: } \\
\text { 17.015- } \\
\text { Rotation } \\
\text { Uncertainty } \\
\text { Dependent }\end{array}$ & $\begin{array}{l}\text { Table 71, } \\
8.17 .15\end{array}$ & $\begin{array}{l}\text { This field is mandatory if Field 17.014: } \\
\text { Rotation angle of eye / RAE is present. }\end{array}$ & 2 & $\mathrm{D}$ & $\begin{array}{l}\text { 17.015- } \\
\text { CondCode } \\
\text { Dependent }\end{array}$ & IF Present(17.014) THEN Present(17.015) & & B \\
\hline \multirow{2}{*}{$\begin{array}{c}\text { Field: } \\
\text { Type17- } \\
\text { CharType }\end{array}$} & \multirow[t]{2}{*}{$\begin{array}{l}8.17 \\
\text { Table } 71\end{array}$} & \multirow[t]{2}{*}{$\begin{array}{l}<\text { Table } 71 \text { specifies the Character Type for } \\
\text { each field that contains no subfields.> }\end{array}$} & 1 & - & $\begin{array}{l}\text { Type17- } \\
\text { CharType N }\end{array}$ & $\begin{array}{l}\text { Bytes }(17 .[001,002,003,005 \text { to } 010,012,022, \\
023,026,031,032,040,041]) \text { MO [0×30 to } 0 \times 39]\end{array}$ & & B \\
\hline & & & 1 & - & $\begin{array}{l}\text { Type17- } \\
\text { CharType A }\end{array}$ & $\begin{array}{l}\text { Bytes }(17 .[013,020,030]) \mathrm{MO}[0 \times 41 \text { to } 0 \times 5 \mathrm{~A} \text {, } \\
\text { 0x61 to } 0 \times 7 \mathrm{~A}]\end{array}$ & & B \\
\hline
\end{tabular}




\begin{tabular}{|c|c|c|c|c|c|c|c|}
\hline & & & 1 & - & $\begin{array}{l}\text { Type17- } \\
\text { CharType } \\
\text { AN }\end{array}$ & $\begin{array}{l}\text { Bytes }(17 .[011,014,015])[0 \times 30 \text { to } 0 \times 39,0 \times 41 \text { to } \\
0 \times 5 A, 0 \times 61 \text { to } 0 \times 7 A]\end{array}$ & B \\
\hline & & & 1 & 0 & $\begin{array}{c}\text { 17.017- } \\
\text { CharType } \\
\text { ANS }\end{array}$ & Bytes(17.017) MO [0x20, 0x7E] & B \\
\hline & & & 1 & 0 & $\begin{array}{l}\text { 17.996- } \\
\text { CharType H }\end{array}$ & $\begin{array}{l}\text { Bytes(10.996) MO [0x30 to } 0 \times 39,0 \times 41 \text { to } 0 \times 46 \text {, } \\
0 \times 61 \text { to } 0 \times 66]\end{array}$ & B \\
\hline \multirow{7}{*}{$\begin{array}{l}\text { Field: } \\
\text { Type17- } \\
\text { Subfield } \\
\text { CharType }\end{array}$} & \multirow[t]{7}{*}{$\begin{array}{c}\text { 8.17, } \\
\text { Table } 71\end{array}$} & \multirow[t]{7}{*}{$\begin{array}{l}<\text { Table } 71 \text { specifies the Character Type for } \\
\text { each subfield.> }\end{array}$} & 1 & M & $\begin{array}{c}\text { 17.004- } \\
\text { Subfield } \\
\text { CharType U }\end{array}$ & Present( Bytes( US_Subfields:1,2 in 17.004 ) & $\mathrm{B}^{*}$ \\
\hline & & & 1 & 0 & $\begin{array}{c}\text { 17.016- } \\
\text { Subfield } \\
\text { CharType N }\end{array}$ & $\begin{array}{l}\text { Bytes(All(US_Subfields in 17.016)) MO [0x30 to } \\
\text { 0x39] }\end{array}$ & $\mathrm{B}^{*}$ \\
\hline & & & 1 & 0 & $\begin{array}{l}\text { 17.019- } \\
\text { Subfield } \\
\text { CharType U }\end{array}$ & Present( Bytes( US_Subfields:1 to 3 in 17.019) & $\mathrm{B}^{*}$ \\
\hline & & & 1 & 0 & $\begin{array}{c}\text { 17.024- } \\
\text { Subfield } \\
\text { CharType } \\
\text { HN }\end{array}$ & $\begin{array}{l}\text { ForEach(RS_Subfield in } 17.024) \\
\{ \\
\text { Bytes(US_Subfields: } 1,3 \text { in RS_Subfield)) MO } \\
\text { [0x30 to } 0 \times 39 \text { ] } \\
\text { AND } \\
\text { Bytes(US_Subfields: } 2 \text { in RS_Subfield)) MO [0×30 } \\
\text { to } 0 \times 39,0 \times 41 \text { to } 0 \times 46,0 \times 61 \text { to } 0 \times 66] \\
\text { \} }\end{array}$ & $\mathrm{B}^{*}$ \\
\hline & & & 1 & M & $\begin{array}{c}17.025- \\
\text { Subfield } \\
\text { CharType } \\
\text { AN }\end{array}$ & $\begin{array}{l}\text { Bytes(US_Subfields: } 1 \text { in } 17.025) \text { ) MO [0x41 to } \\
\text { Ox5A, } 0 \times 61 \text { to } 0 \times 7 A]] \\
\text { AND } \\
\text { Bytes(US_Subfields: } 2,3 \text { in } 17.025) \text { ) MO [0x30 to } \\
\text { 0x39] }\end{array}$ & $\mathrm{B}^{*}$ \\
\hline & & & 1 & M & $\begin{array}{c}17.033- \\
\text { Subfield } \\
\text { CharType } \\
\text { AN }\end{array}$ & 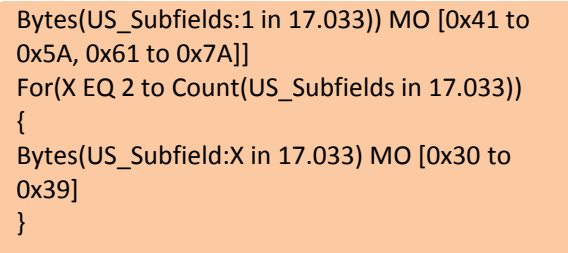 & $\mathrm{B}^{*}$ \\
\hline & & & 1 & 0 & $\begin{array}{c}\text { 17.034- } \\
\text { Subfield } \\
\text { CharType } \\
\text { AN }\end{array}$ & 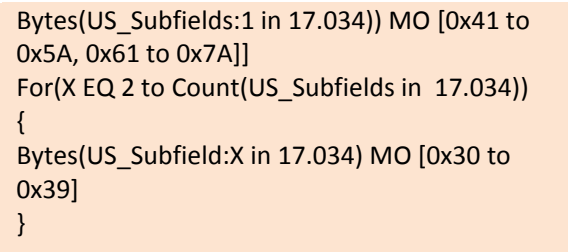 & $\mathrm{B}^{*}$ \\
\hline
\end{tabular}



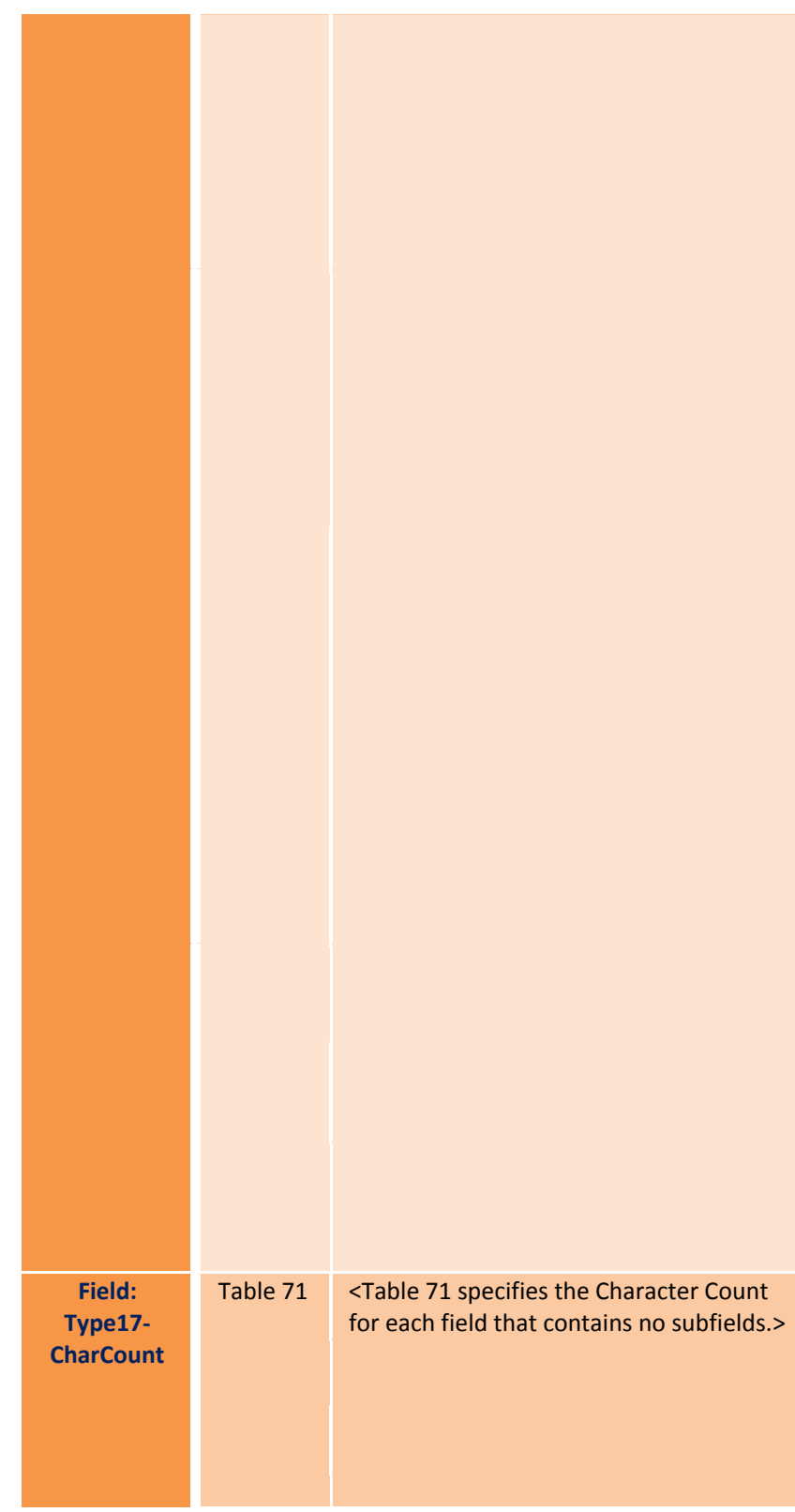

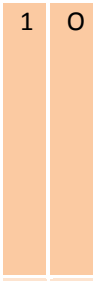

\begin{tabular}{l|l|r}
1 & 0 & $\begin{array}{c}17.036- \\
\text { Subfield } \\
\text { CharType }\end{array}$ \\
\hline
\end{tabular} CharType
AN 17.035-
Subfield
CharType AN

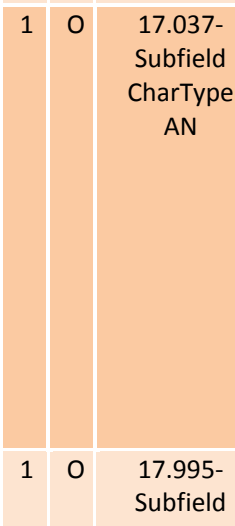

10 17.997Subfield CharType N

O $\quad 17.998-$ Subfield CharTyp ANSU

1 M 17.001CharCount

1 M 17.002-

1 M 17.003-

CharCount

1 M 17.005-
Bytes(US Subfields: 1 in 17.035)) MO [0x41 to $0 \times 5 \mathrm{~A}, 0 \times 61$ to $0 \times 7 \mathrm{~A}]$

For(X EQ 2 to Count(US_Subfields in 17.035)

Bytes(US_Subfield:X in 17.035) MO [0x30 to

0x39]

\}

Bytes(US Subfields: 1 in 17.036)) MO [0x41 to $0 \times 5 \mathrm{~A}, 0 \times 61$ to $0 \times 7 \mathrm{~A}]$

For(X EQ 2 to Count(US_Subfields in 17.036)) \{

Bytes(US_Subfield:X in 17.036) MO [0x30 to 0x39]

ForEach(RS_Subfield in 17.037)

Bytes(US Subfields:1,2 in RS_Subfield)) MO [0x41 to $0 \times 5 \mathrm{~A}, 0 \times 61$ to $0 \times 7 \mathrm{~A}$ ]]

AND

For(X EQ 3 to Count(US_Subfields in

RS_Subfield))

Bytes(US_Subfield:X in RS_Subfield) MO [0×30 to 0x39]

\}

Bytes(All(US_Subfields:1,2 in 17.995)) MO [0x30 to $0 \times 39$ ]

Bytes(All(US_Subfields:1,2 in 17.997)) MO [0x30 to $0 \times 39$ ]

<See Requirement ID: “Field: Geographic">

$\mathrm{t}-2$

DataLength(17.001) GTE 1

DataLength(17.002) EQ 1 OR 2

DataLength(17.003) EQ 1

DataLength(17.005) EQ 8
$\mathrm{B}^{*}$ 


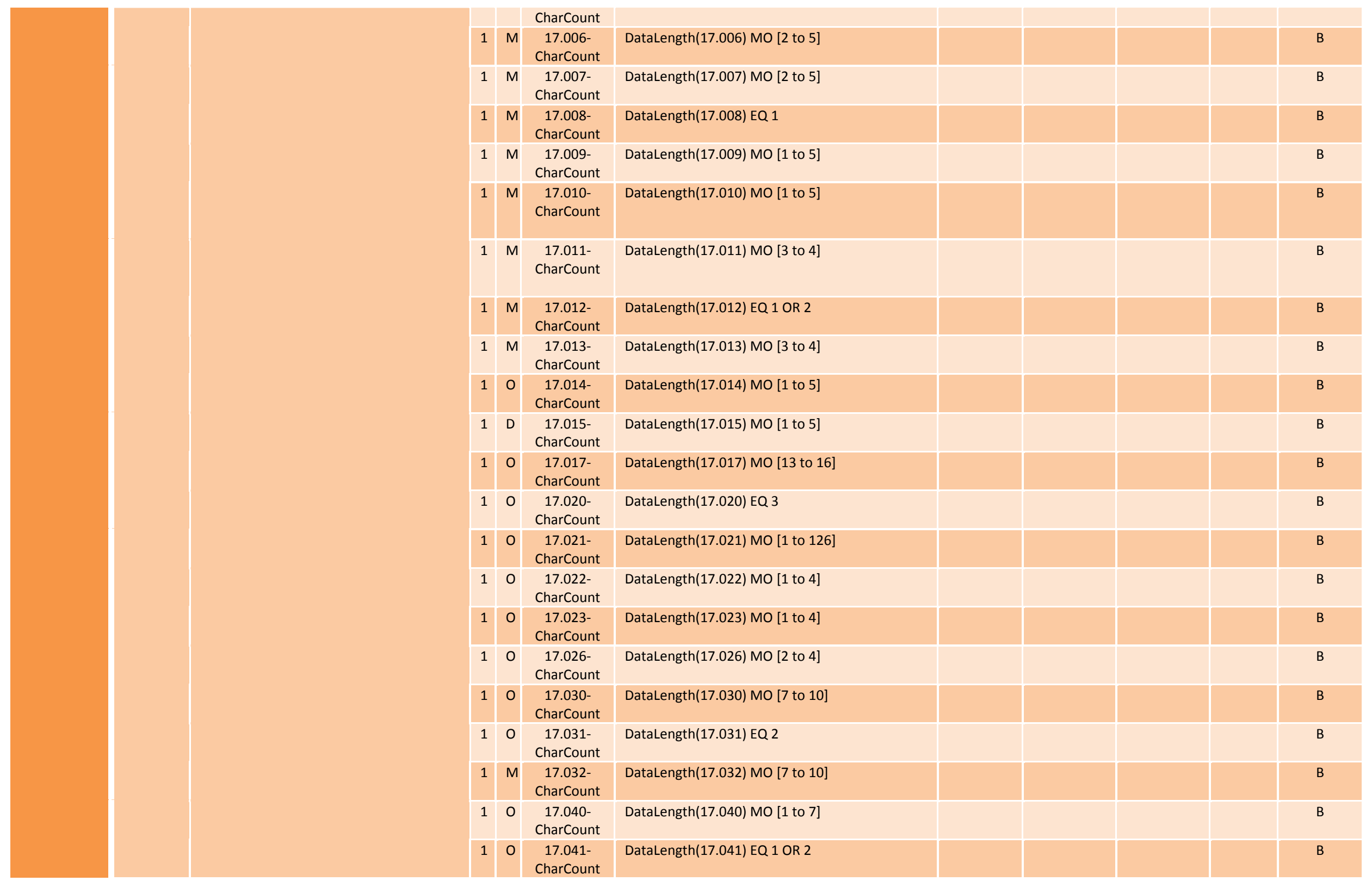




\begin{tabular}{|c|c|c|c|c|c|c|c|}
\hline & & & 1 & 0 & $\begin{array}{l}\text { 17.996- } \\
\text { CharCount }\end{array}$ & DataLength(17.995) EQ 64 & B \\
\hline & & & 1 & $M$ & $\begin{array}{l}\text { 17.999- } \\
\text { CharCount }\end{array}$ & DataLength(17.999) GTE 1 & B \\
\hline \multirow{6}{*}{$\begin{array}{l}\text { Field: } \\
\text { Type17- } \\
\text { Subfield } \\
\text { CharCount }\end{array}$} & \multirow[t]{6}{*}{ Table 71} & \multirow[t]{6}{*}{$\begin{array}{l}<\text { Table } 71 \text { specifies the Character Count } \\
\text { for each subfield.> }\end{array}$} & 1 & M & $\begin{array}{l}\text { 17.004- } \\
\text { Subfield } \\
\text { CharCount }\end{array}$ & Length(All(US_Subfields in 17.004)) GTE 1 & $\mathrm{~B}^{*}$ \\
\hline & & & 1 & 0 & $\begin{array}{l}\text { 17.016- } \\
\text { Subfield } \\
\text { CharCount }\end{array}$ & Length(All(US_Subfields in 17.016)) EQ 1 & $\mathrm{~B}^{*}$ \\
\hline & & & 1 & 0 & $\begin{array}{l}\text { 17.019- } \\
\text { Subfield } \\
\text { CharCount }\end{array}$ & Length(All(US_Subfields in 17.019)) MO [1 to 50] & $\mathrm{B}^{*}$ \\
\hline & & & 1 & 0 & $\begin{array}{l}\text { 17.024- } \\
\text { Subfield } \\
\text { CharCount }\end{array}$ & $\begin{array}{l}\text { ForEach(RS_Subfield in 17.024) } \\
\text { \{ } \\
\text { Length(US_Subfields:1 in RS_Subfield)) MO [1 to } \\
\text { 3] } \\
\text { AND } \\
\text { Length(US_Subfields: } 2 \text { in RS_Subfield)) EQ } 4 \\
\text { AND } \\
\text { Length(US_Subfields: } 3 \text { in RS_Subfield)) MO [1 to } \\
\text { 5] } \\
\}\end{array}$ & $\mathrm{B}^{*}$ \\
\hline & & & 1 & M & $\begin{array}{l}\text { 17.025- } \\
\text { Subfield } \\
\text { CharCount }\end{array}$ & $\begin{array}{l}\text { ForEach(RS_Subfield in 17.025) } \\
\{ \\
\text { Length(US_Subfields: } 1 \text { in RS_Subfield)) MO [ } 3 \text { to } \\
\text { 9] } \\
\text { AND } \\
\text { Length(US_Subfields:2,3 in RS_Subfield)) EQ } 3 \\
\}\end{array}$ & $\mathrm{B}^{*}$ \\
\hline & & & 1 & 0 & $\begin{array}{l}\text { 17.023- } \\
\text { Subfield } \\
\text { CharCount }\end{array}$ & 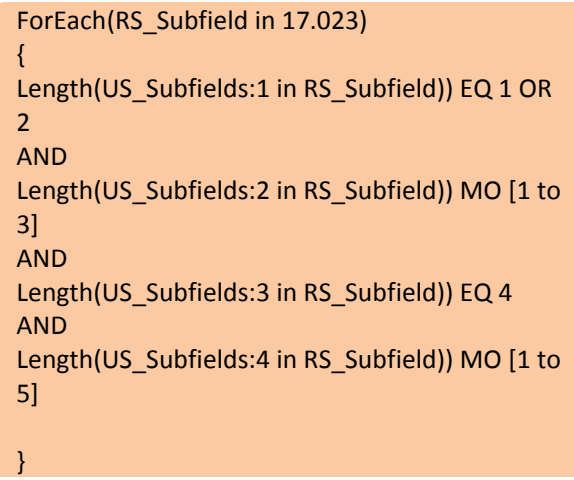 & $\mathrm{B}^{*}$ \\
\hline
\end{tabular}



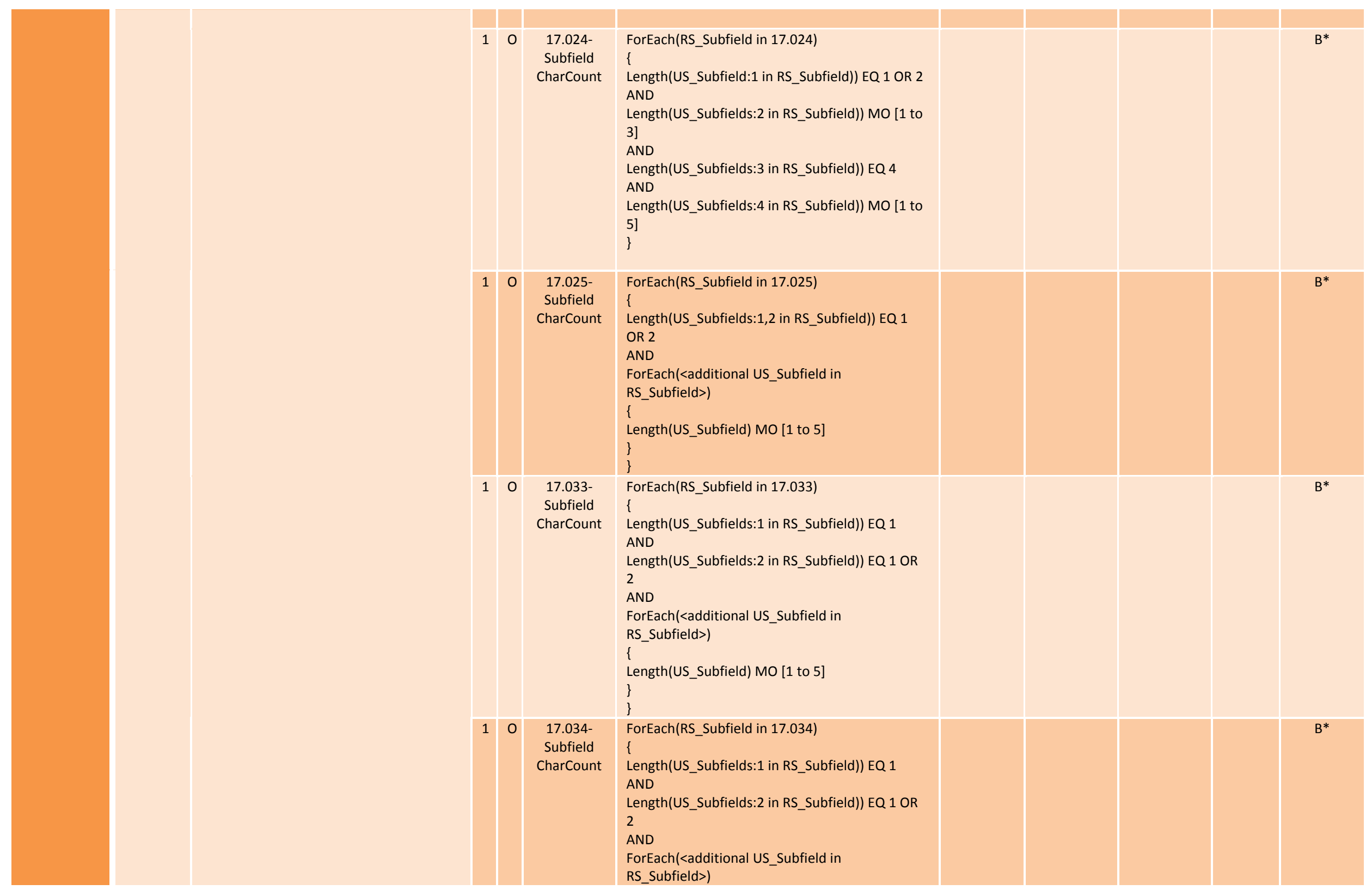

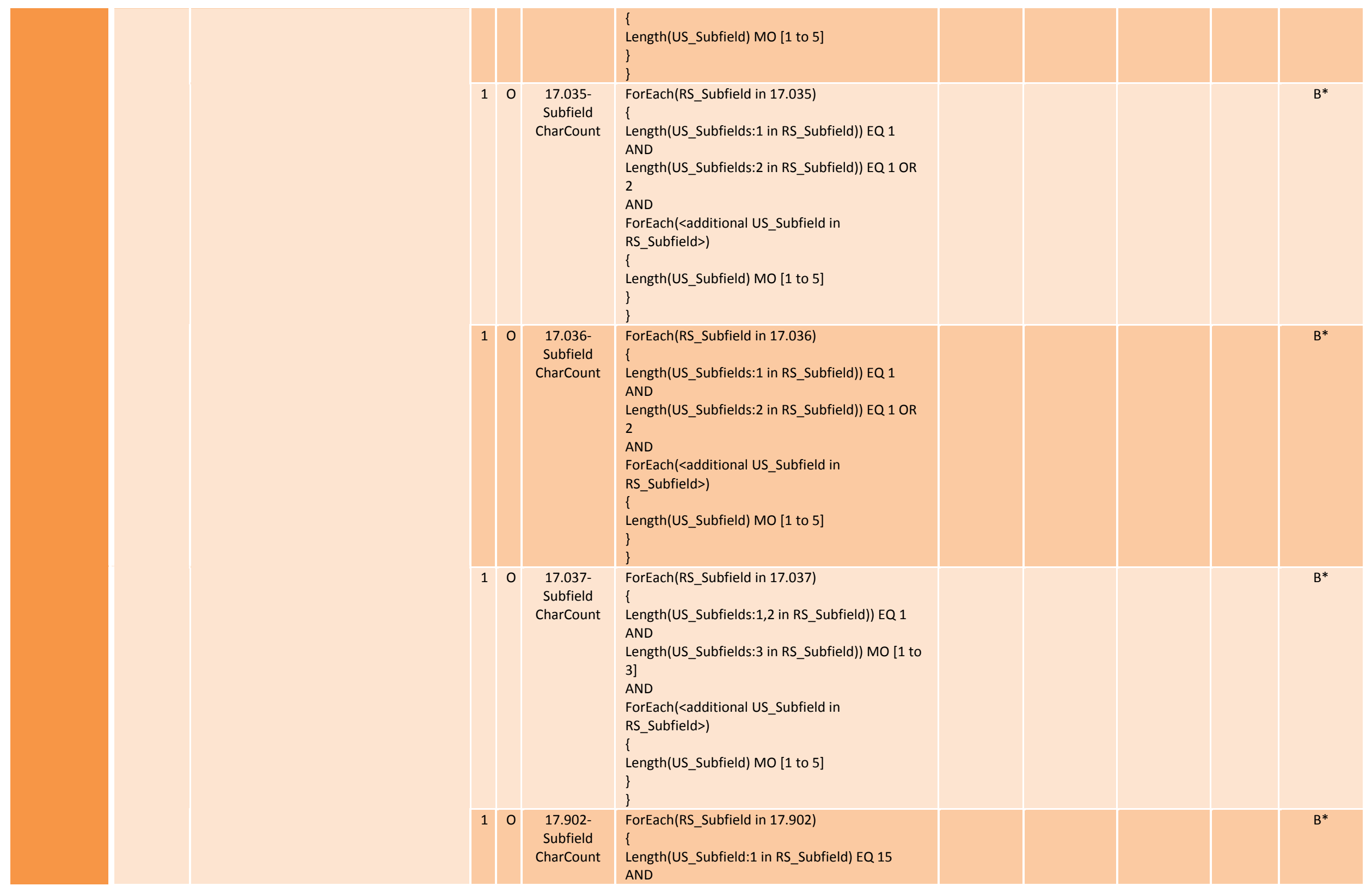


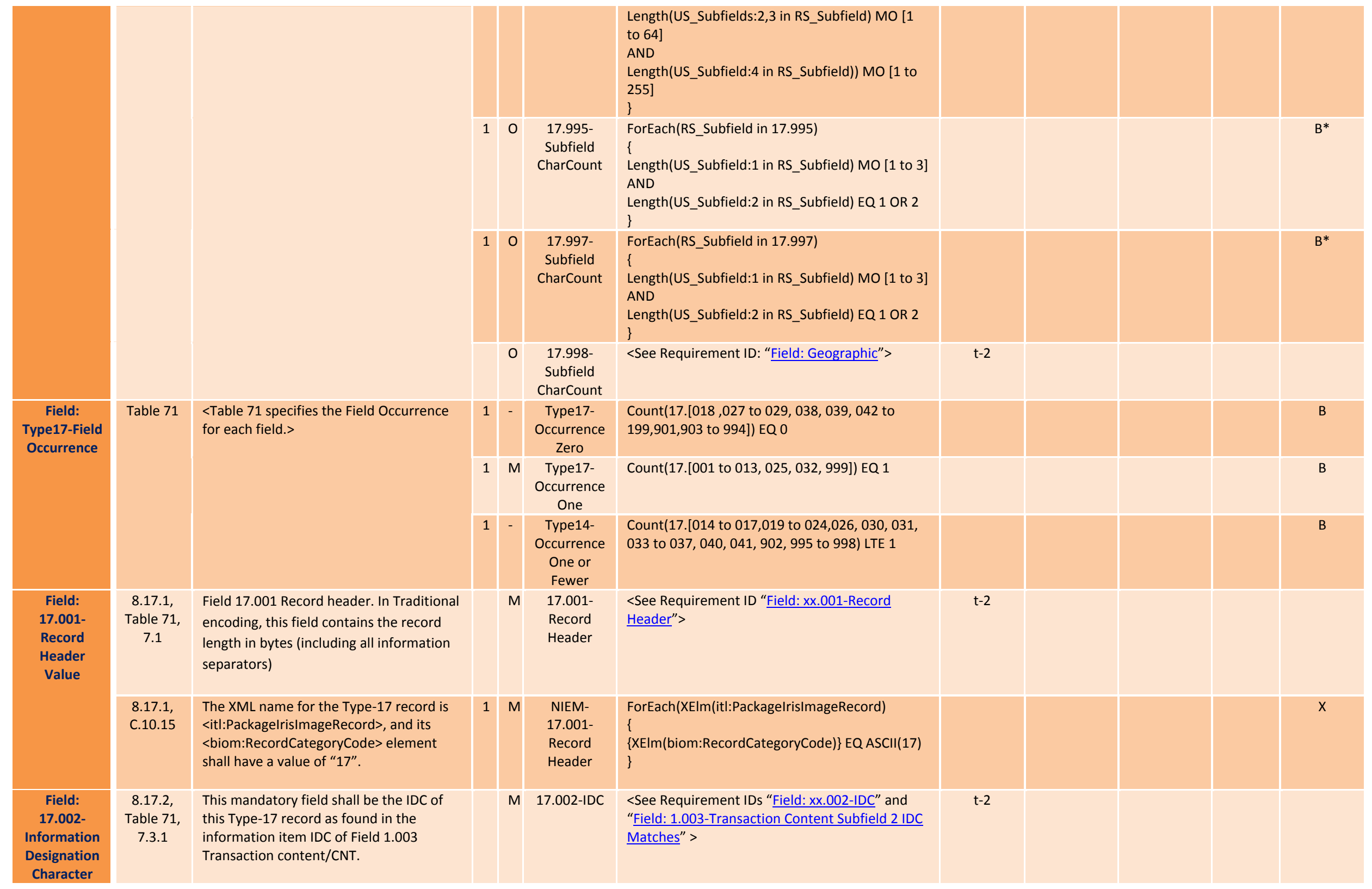




\begin{tabular}{|c|}
\hline Value \\
\hline $\begin{array}{l}\text { Field: } \\
\text { 17.003-Eye } \\
\text { Label } \\
\text { Value }\end{array}$ \\
\hline $\begin{array}{l}\text { Field: } \\
\text { 17.004- } \\
\text { Originating } \\
\text { Agency } \\
\text { Value }\end{array}$ \\
\hline $\begin{array}{c}\text { Field: } \\
\text { 17.005-Iris } \\
\text { Capture } \\
\text { Date Value }\end{array}$ \\
\hline $\begin{array}{l}\text { Field: } \\
\text { 17.006- } \\
\text { Horizontal } \\
\text { Line Length } \\
\text { Value }\end{array}$ \\
\hline $\begin{array}{l}\text { Field: } \\
\text { 17.006- } \\
\text { Horizontal } \\
\text { Line Length } \\
\text { Metadata }\end{array}$ \\
\hline $\begin{array}{l}\text { Field: } \\
\text { 17.007- } \\
\text { Vertical Line } \\
\text { Length } \\
\text { Value }\end{array}$ \\
\hline $\begin{array}{l}\text { Field: } \\
\text { 17.007- } \\
\text { Vertical Line } \\
\text { Length } \\
\text { Metadata }\end{array}$ \\
\hline $\begin{array}{c}\text { Field: } \\
\text { 17.008-Scale } \\
\text { Units Value }\end{array}$ \\
\hline $\begin{array}{c}\text { Field: } \\
\text { 17.008- } \\
\text { Scale Units } \\
\text { Metadata }\end{array}$ \\
\hline
\end{tabular}

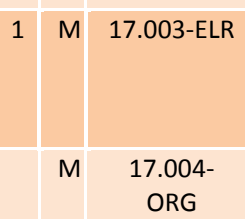

1 M 17.003-ELR 17.003-ELR

M $\quad \begin{gathered}17.004 \\ \text { ORG }\end{gathered}$

1 M 17.005-ICD

1 M NIEM17.005-ICD

contained in the record was captured.

The maximum horizontal size is limited to

65,534 pixels in Record Types-4 and 8,

and to 99,999 for other record types. The minimum value is 10 pixels.

8.17.6, <The HLL is verified by checking the imag

Table 71, metadata if compression is used.>

7.7.8.1

8.17.7, The maximum vertical size is limited to

Table 71, 65,534 pixels in Record Types-4 and 8,

7.7.8.2 and to 99,999 for other record types.

The minimum value is 10 pixels.

<The VLL is verified by checking the image

Table 71, metadata if compression is used.>

7.7.8.2

8.17 .8

Table 71,

7.7 .8 .3

8.17.8,

Table 71,

7.7.8.3

A value

A value of " 2 " shall indicate pixels per centimeter. A value of " 0 " in this field indicates that no scale is provided, and

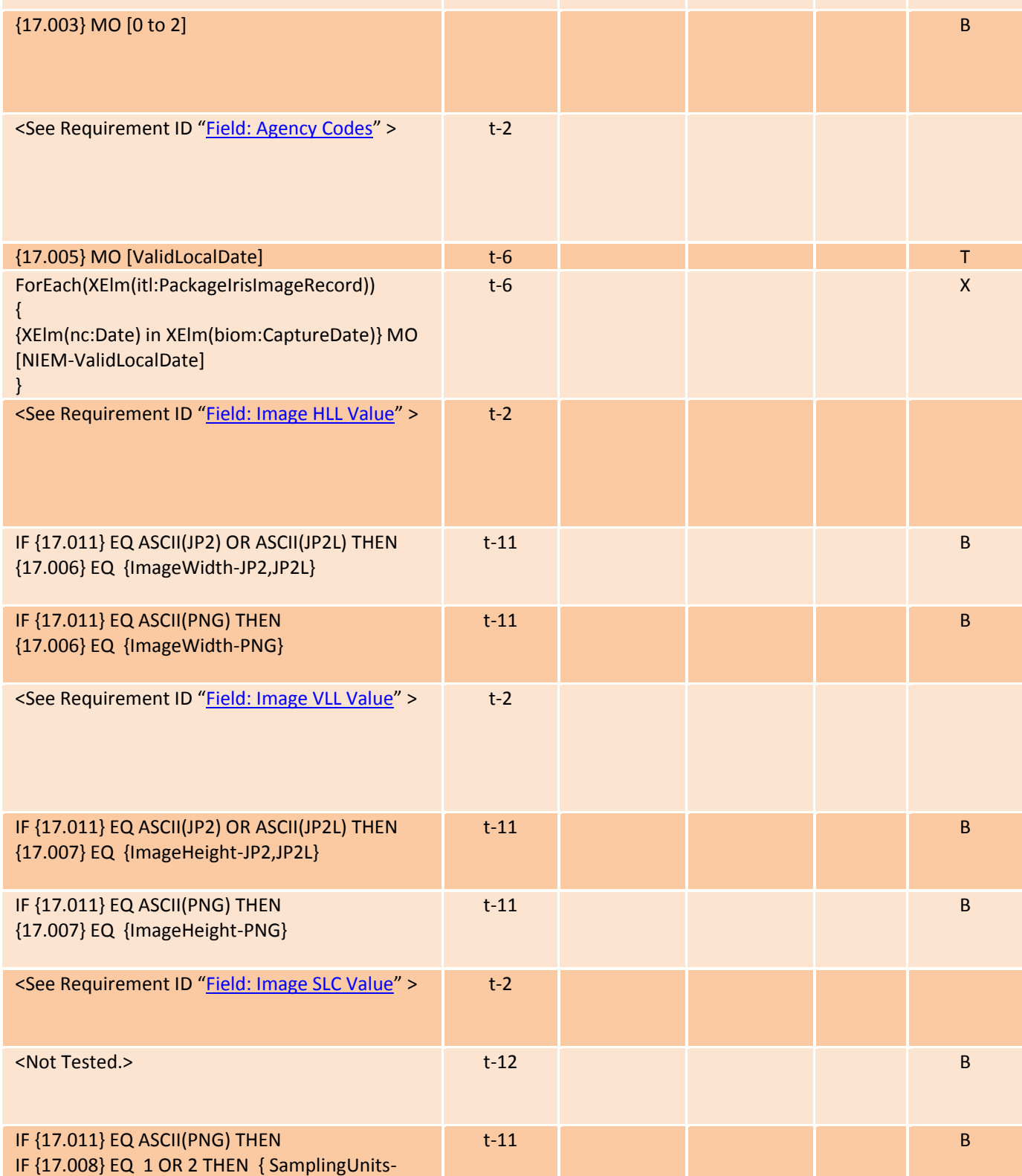




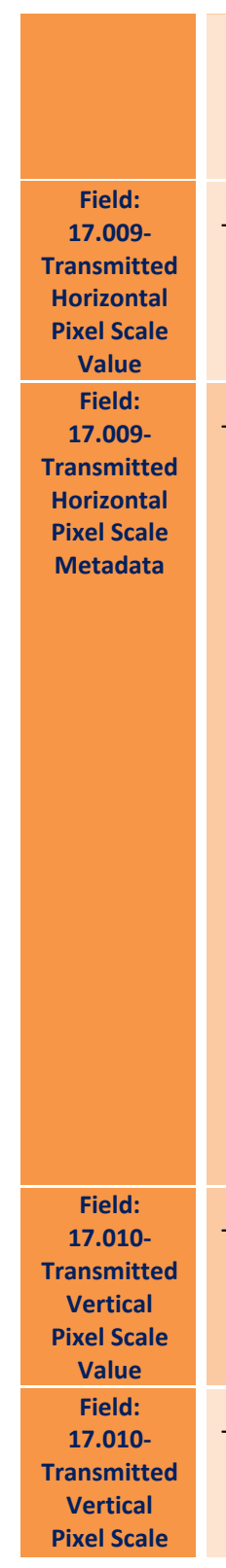

the quotient of THPS/TVPS shall provide the pixel aspect ratio.

$<$ The SLC is verified by checking the image metadata if compression is used.>

8.17.9, <Table 71 lists the value constraints for Table 71, THPS.>

7.7.8.4

$$
\text { HPS.> }
$$

8.17.9, This is the integer pixel density used in

Table 71, the horizontal direction of the image if

7.7.8.4 SLC has a value of "1" or "2". If SLC has a value of " 0 ", this information item shall contain the horizontal component of the pixel aspect ratio, up to 5 digits.

$<$ The THPS is verified by checking the image metadata if compression is used.>

8.17.10, <Table 71 lists the value constraints for Table 71,

7.7.8.5

8.17.10,

Table 71,

7.7 .8 .5

This is the integer pixel density used in the Vertical direction of the image if SLC

has a value of " 1 " or " 2 ". If SLC has a

value of " 0 ", this information item shall contain the Vertical component of the

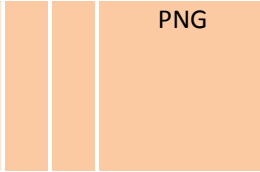

M 17.009THPS

\begin{tabular}{|c|c|c|}
\hline & & $\begin{array}{l}\text { 17.009- } \\
\text { THPS } \\
\text { Metadata } \\
\text { JP2, JP2L }\end{array}$ \\
\hline 2 & $M$ & $\begin{array}{l}\text { 17.009- } \\
\text { THPS } \\
\text { Metadata } \\
\text { PNG }\end{array}$ \\
\hline
\end{tabular}

17.009- $<$ Not Tested. $>$

THPS

Aspect

Ratio

Metadata

JP2, JP2L

2 M 17.009-

IF $\{17.011\}$ EQ ASCII(PNG) AND $\{17.008\}$ NEQ 1

THPS OR 2

Aspect THEN $\{17.009\} /\{17.010\}$ EQ \{HorizontalDensity-

Metadata

PNG

M 17.010

M $\quad 17.010-$

$>$

$>$
$<$ Not Tested.>

IF $\{17.011\}$ EQ ASCII(PNG) AND $\{17.008\}$ EQ 1

THEN $\{17.009\}$ EQ $\{$ HorizontalDensity-PNG

0.0254 (meters/inch)

ELSE IF $\{17.011\}$ EQ ASCII(PNG) AND $\{17.008\}$ EQ

THEN $\{17.009\}$ EQ $\left\{\right.$ HorizontalDensity-PNG ${ }^{*}$

0.01 (meters $/ \mathrm{cm}$ )

PNG $/$ \{VerticalDensity-PNG

<See Requirement ID “Field: Image TVPS Value”

$<$ Not Tested.>

$\mathrm{t}-12$

B

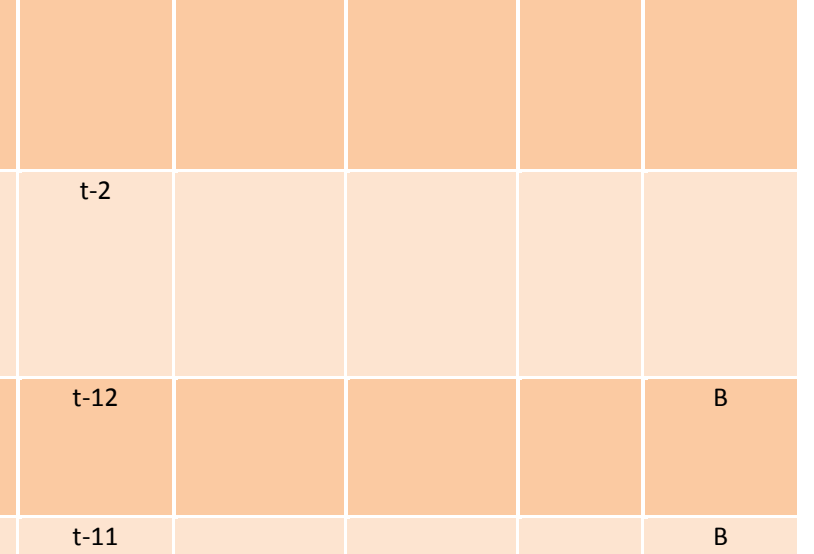

t-11

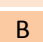

$\mathrm{t}-1$

$-11$

IF $\{17.011\}$ EQ ASCII(PNG) AND $\{17.008\}$ EQ 1

TVPS

Metadata

JP2, JP2L

2 M 17.010- 


\begin{tabular}{|c|c|c|c|c|c|c|c|c|}
\hline \multirow[t]{3}{*}{ Metadata } & & $\begin{array}{l}\text { pixel aspect ratio, up to } 5 \text { digits. } \\
\text { <The TVPS is verified by checking the } \\
\text { image metadata if compression is used.> }\end{array}$ & & & $\begin{array}{l}\text { TVPS } \\
\text { Metadata } \\
\text { PNG }\end{array}$ & $\begin{array}{l}\text { THEN }\{17.010\} \text { EQ }\{\text { VerticalDensity-PNG }\} \text { * } \\
0.0254 \text { (meters/inch), } \\
\text { ELSE IF }\{17.011\} \text { EQ ASCII(PNG) AND }\{17.008\} \text { EQ } \\
2 \\
\text { THEN }\{17.010\} \text { EQ }\{\text { VerticalDensity-PNG }\} * 0.01 \\
\text { (meters/cm) }\end{array}$ & & \\
\hline & & & & & $\begin{array}{l}\text { 17.010- } \\
\text { TVPS } \\
\text { Aspect } \\
\text { Ratio } \\
\text { Metadata } \\
\text { JP2, JP2L }\end{array}$ & $<$ Not Tested. $>$ & $\mathrm{t}-12$ & B \\
\hline & & & 2 & M & $\begin{array}{l}\text { 17.010- } \\
\text { TVPS } \\
\text { Aspect } \\
\text { Ratio } \\
\text { Metadata } \\
\text { PNG }\end{array}$ & $\begin{array}{l}\text { IF }\{17.011\} \text { EQ ASCII(PNG) AND }\{17.008\} \text { NEQ } 1 \\
\text { OR } 2 \\
\text { THEN }\{17.009\} /\{17.010\} \text { EQ }\{\text { HorizontalDensity - } \\
\text { PNG } /\{\text { VerticalDensity-PNG }\}\end{array}$ & $\mathrm{t}-11$ & B \\
\hline $\begin{array}{l}\text { Field: } \\
\text { 17.011- } \\
\text { Compressio } \\
\text { n Algorithm } \\
\text { Value }\end{array}$ & $\begin{array}{l}\text { 8.17.11, } \\
\text { Table 71, } \\
\text { 7.7.9.1 }\end{array}$ & $\begin{array}{l}\text { For each of these fields, the entry } \\
\text { corresponds to the appropriate Label } \\
\text { entry in Table 12: Field 17.011: } \\
\text { Compression algorithm / CGA. }\end{array}$ & & M & 17.011-CGA & $\begin{array}{l}\text { <See Requirement ID "Field: Type17 } \\
\text { Compression".> }\end{array}$ & $\mathrm{t}-2$ & \\
\hline \multirow{2}{*}{$\begin{array}{l}\text { Field: } \\
\text { 17.011- } \\
\text { Compressio } \\
\text { n Algorithm } \\
\text { Metadata }\end{array}$} & \multirow[t]{2}{*}{$\begin{array}{l}\text { 8.17.11, } \\
\text { Table } 71\end{array}$} & \multirow[t]{2}{*}{$\begin{array}{l}<\text { The CGA is verified by checking the } \\
\text { image metadata for the compression type } \\
\text { signature if compression is used.> }\end{array}$} & 2 & M & $\begin{array}{l}\text { 17.011-CGA } \\
\text { Metadata } \\
\text { JP2, JP2L }\end{array}$ & $\begin{array}{l}\text { IF }\{17.011\} \text { EQ ASCII(JP2) OR ASCII(JP2L) THEN } \\
\text { Present(SigBox) }\end{array}$ & $\mathrm{t}-11$ & B \\
\hline & & & 2 & M & $\begin{array}{l}\text { 17.011-CGA } \\
\text { Metadata } \\
\text { PNG }\end{array}$ & $\begin{array}{l}\text { IF }\{17.011\} \text { EQ ASCII(PNG) THEN } \\
\text { Present(PNGSig) }\end{array}$ & $\mathrm{t}-11$ & B \\
\hline $\begin{array}{l}\text { Field: } \\
\text { 17.012-Bits } \\
\text { Per Pixel } \\
\text { Value }\end{array}$ & $\begin{array}{l}\text { 8.17.12, } \\
\text { Table 71, } \\
\text { 7.7.8.6 }\end{array}$ & $\begin{array}{l}\text { This field shall contain an entry of " } 8 \text { " for } \\
\text { normal grayscale values of " } 0 \text { " to " } 255 \text { ". } \\
\text { Any entry in this field greater than " } 8 \text { " } \\
\text { shall represent a grayscale pixel with } \\
\text { increased proportion. }\end{array}$ & & M & 17.012-BPX & <See Requirement ID “Field: Image BPX Value" > & $t-2$ & \\
\hline \multirow{2}{*}{$\begin{array}{l}\text { Field: } \\
\text { 17.012- Bits } \\
\text { Per Pixel } \\
\text { Metadata }\end{array}$} & \multirow[t]{2}{*}{$\begin{array}{l}\text { 8.17.12, } \\
\text { Table } 71\end{array}$} & \multirow[t]{2}{*}{$\begin{array}{l}<\text { The BPX is verified by checking the } \\
\text { image metadata for the compression type } \\
\text { signature if compression is used.> }\end{array}$} & 2 & M & $\begin{array}{l}\text { 17.012-BPX } \\
\text { Metadata } \\
\text { JP2, JP2L }\end{array}$ & $\{17.012\}$ EQ $\{B P X-J P 2, J P 2 L\}$ & $\mathrm{t}-11$ & B \\
\hline & & & 2 & M & $\begin{array}{l}\text { 17.012-BPX } \\
\text { Metadata } \\
\text { PNG }\end{array}$ & $\{17.012\}$ EQ $\{B P X-P N G\}$ & $\mathrm{t}-11$ & B \\
\hline $\begin{array}{l}\text { Field: } \\
\text { 17.013-Color } \\
\text { Space Value }\end{array}$ & $\begin{array}{c}\text { 8.17.13, } \\
\text { Table } 71 \\
7.7 .10\end{array}$ & $\begin{array}{l}\text { Table } 13 \text { lists the codes and their } \\
\text { descriptions for each of the available } \\
\text { color spaces used within this standard. } \\
\text { All other color spaces are to be marked as } \\
\text { undefined. }\end{array}$ & & M & 17.013-CSP & <See Requirement ID: “Field: Image CSP Value”.> & $\mathrm{t}-2$ & \\
\hline
\end{tabular}




\begin{tabular}{|c|c|c|c|c|c|c|c|c|}
\hline $\begin{array}{l}\text { Field: } \\
\text { 17.014- } \\
\text { Rotation } \\
\text { Angle of Eye } \\
\text { Value }\end{array}$ & $\begin{array}{l}\text { 8.17.14, } \\
\text { Table } 71\end{array}$ & $\begin{array}{l}\text { The in-plane eye rotation angle shall be } \\
\text { recorded as angle }=\text { round }\left(65536^{*} \text { angle }\right. \\
\text { / } 360 \text { ) modulo } 65536 \text {. The value "FFFF" } \\
\text { indicates rotation angle of eye is } \\
\text { undefined. } \\
<\text { Table } 71 \text { lists the value constraints for } \\
\text { RAE.> }\end{array}$ & 1 & 0 & 17.014-RAE & $\{17.014\} \mathrm{MO}$ [0 to 65535$]$ OR EQ ASCII(FFFF) & & B \\
\hline $\begin{array}{l}\text { Field: } \\
\text { 17.015- } \\
\text { Rotation } \\
\text { Uncertainty } \\
\quad \text { Value }\end{array}$ & $\begin{array}{l}\text { 8.17.15, } \\
\text { Table } 71\end{array}$ & $\begin{array}{l}\text { The rotation uncertainty is non-negative } \\
\text { and equal to [round ( } 655366^{*} \text { uncertainty } \\
\text { / 180)]. The uncertainty is measured in } \\
\text { degrees and is the absolute value of } \\
\text { maximum error. The value "FFFF" } \\
\text { indicates uncertainty is undefined. } \\
\text { <Table } 71 \text { lists the value constraints for } \\
\text { RAU.> }\end{array}$ & 1 & $\mathrm{D}$ & $\begin{array}{l}\text { 17.014- } \\
\text { RAU }\end{array}$ & $\{17.015\} \mathrm{MO}$ [0 to 65535$]$ OR EQ ASCII(FFFF) & & B \\
\hline $\begin{array}{l}\text { Field: } \\
\text { 17.015- } \\
\text { Rotation } \\
\text { Uncertainty } \\
\text { Conditional }\end{array}$ & $\begin{array}{l}\text { 8.17.15, } \\
\text { Table } 71\end{array}$ & $\begin{array}{l}\text { This optional field shall indicate the } \\
\text { uncertainty in the in-plane eye rotation } \\
\text { given in Field 17.014: Rotation angle of } \\
\text { eye / RAE. This field is mandatory if Field } \\
\text { 17.014: Rotation angle of eye / RAE is } \\
\text { present. }\end{array}$ & & $\mathrm{D}$ & $\begin{array}{l}\text { 17.014- } \\
\text { RAU } \\
\text { Conditional }\end{array}$ & $\begin{array}{l}\text { <See Requirement ID: “Field: 17.015-Rotation } \\
\text { Uncertainty Dependent".> }\end{array}$ & $\mathrm{t}-2$ & \\
\hline $\begin{array}{l}\text { Field: } \\
\text { 17.016- } \\
\text { Image } \\
\text { Property } \\
\text { Code Value }\end{array}$ & $\begin{array}{l}\text { 8.17.16, } \\
\text { Table } 71\end{array}$ & $\begin{array}{l}<\text { Table } 71 \text { lists the value constraints for } \\
\text { IPC.> }\end{array}$ & 1 & 0 & $17.016-I P C$ & $\begin{array}{l}\text { \{US_Subfield:1,2 in } 17.016\} \text { MO [0 to 2] } \\
\text { AND } \\
\text { \{US_Subfield:3 in } 17.016\} \text { EQ O OR } 1\end{array}$ & & $\mathrm{~B}^{*}$ \\
\hline $\begin{array}{l}\text { Field: } \\
\text { 17.017- } \\
\text { Device } \\
\text { Unique } \\
\text { Value }\end{array}$ & $\begin{array}{l}\text { 8.17.17, } \\
\text { Table } 71\end{array}$ & $\begin{array}{l}\text { See Section 7.7.1.1 for details. } \\
<\text { Table } 71 \text { lists the value constraints for } \\
\text { DUI.> }\end{array}$ & & 0 & 17.017-DUI & <See Requirement ID: “Field: Device ID”. $>$ & $t-2$ & \\
\hline $\begin{array}{l}\text { Field: } \\
\text { 17.018- } \\
\text { Deprecated }\end{array}$ & Table 71 & $\begin{array}{l}\text { Deprecated; See ANSI/NIST-ITL 1-2007 for } \\
\text { a description of this field. Not to be used } \\
\text { for any new transactions. }\end{array}$ & & - & $\begin{array}{l}\text { 17.019- } \\
\text { Deprecated }\end{array}$ & $\begin{array}{l}\text { <See Requirement ID: “Field: Type17- } \\
\text { CondCode>. }\end{array}$ & $\mathrm{t}-2$ & \\
\hline $\begin{array}{l}\text { Field: } \\
\text { 17.019- } \\
\text { Make/Mode } \\
\text { I/Serial } \\
\text { Number } \\
\text { Value }\end{array}$ & $\begin{array}{c}\text { 8.17.18, } \\
\text { 7.7.1.2, } \\
\text { Table } 71\end{array}$ & $\begin{array}{l}\text { See Section 7.7.1.2 for details. } \\
<\text { Table } 71 \text { lists the value constraints for } \\
\text { MMS.> }\end{array}$ & & 0 & $\begin{array}{l}\text { 17.019- } \\
\text { MMS }\end{array}$ & <See Requirement ID: "Field: Make Model". > & $\mathrm{t}-2$ & \\
\hline $\begin{array}{l}\text { Field: } \\
\text { 17.020-Eye } \\
\text { Color Value }\end{array}$ & $\begin{array}{c}\text { 8.17.19, } \\
\text { 7.7.11, } \\
\text { Table 71, } \\
\text { Table 14 }\end{array}$ & $\begin{array}{l}\text { See Section } 7.7 .11 \text { and Table } 14 \text { for } \\
\text { details on entering values to this field. } \\
\text { <Table } 71 \text { lists the value constraints for } \\
\text { ECL.> }\end{array}$ & & 0 & 17.020-ECL & <See Requirement ID: “Field: Image ECL Value”. $>$ & $\mathrm{t}-2$ & \\
\hline
\end{tabular}




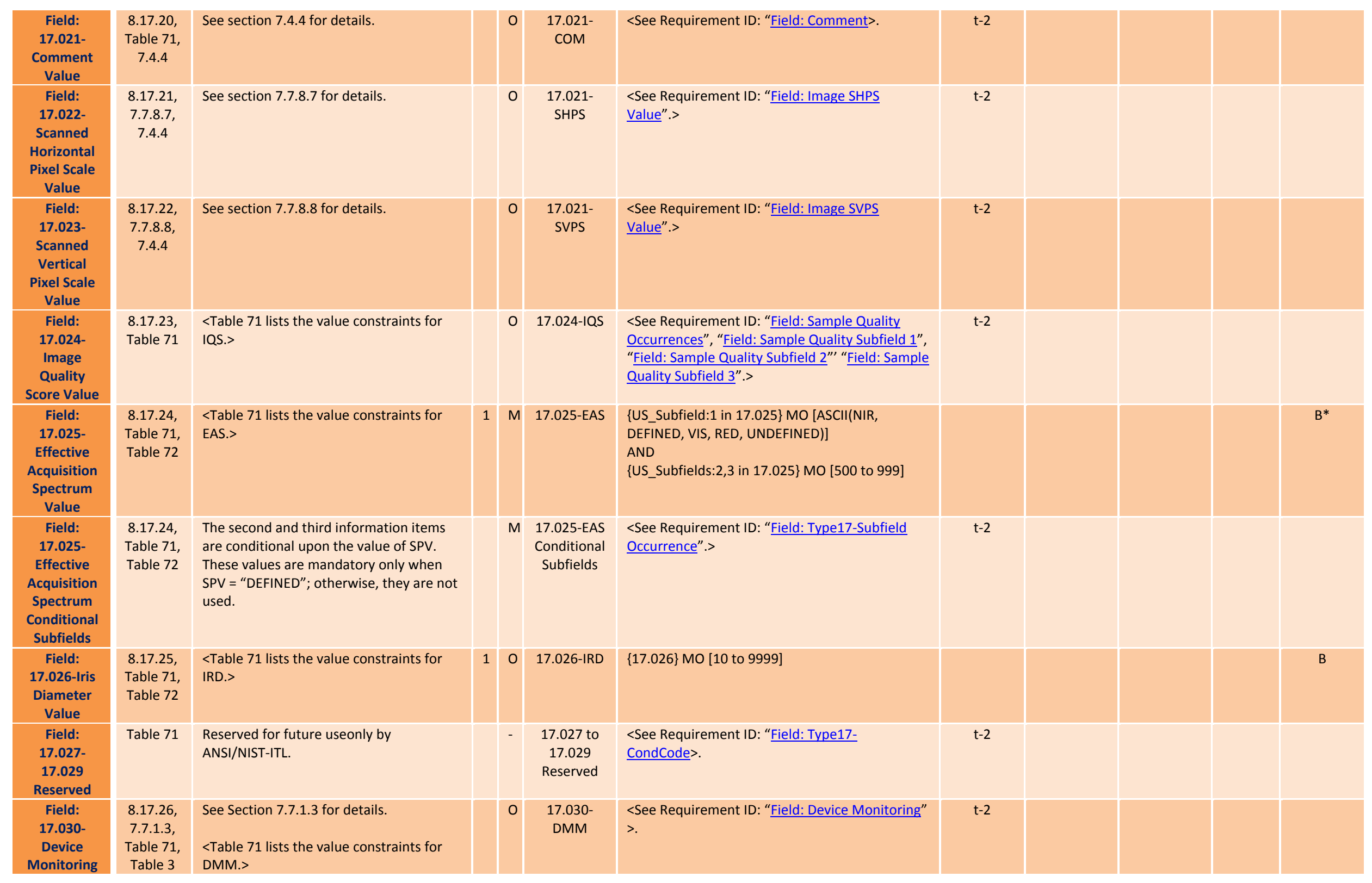




\begin{tabular}{|c|c|c|c|c|c|c|c|c|}
\hline \multicolumn{9}{|l|}{ Mode Value } \\
\hline $\begin{array}{l}\text { Field: } \\
\text { 17.031- } \\
\text { Subject } \\
\text { Acquisition } \\
\text { Profile-Iris } \\
\text { Value }\end{array}$ & 8.17 .27 & $\begin{array}{l}<\text { Table } 71 \text { lists the value constraints for } \\
\text { IAP.> }\end{array}$ & & 0 & 17.031-IAP & <See Requirement ID: "Field: IAP Values" >. & $\mathrm{t}-2$ & \\
\hline $\begin{array}{l}\text { Field: } \\
\text { 17.032-Iris } \\
\text { Storage } \\
\text { Format } \\
\text { Value }\end{array}$ & 8.17 .28 & $\begin{array}{l}<\text { Table } 71 \text { lists the value constraints for } \\
\text { ISF.> }\end{array}$ & 1 & M & 17.032-ISF & $\{17.032\} \mathrm{MO}[1$ to 3,7$]$ & & B \\
\hline \multirow{3}{*}{$\begin{array}{l}\text { Field: } \\
\text { 17.033-Iris } \\
\text { Pupil } \\
\text { Boundary } \\
\text { Value }\end{array}$} & \multirow[t]{3}{*}{$\begin{array}{l}\text { 8.17.29, } \\
\text { Table 71, } \\
\text { Table } 16\end{array}$} & \multirow[t]{3}{*}{$\begin{array}{l}<\text { Table } 71 \text { lists the value constraints for } \\
\text { IPB.> }\end{array}$} & 1 & $\begin{array}{l}M \\
\Uparrow\end{array}$ & $\begin{array}{c}17.033- \\
\text { Subfield } 1 \text { - } \\
\text { BYC }\end{array}$ & $\{$ US_Subfield:1 in 17.033$\} \mathrm{MO}[\mathrm{ASCII}(\mathrm{C}, \mathrm{E}, \mathrm{P})]$ & & $\mathrm{B}^{*}$ \\
\hline & & & 1 & $\begin{array}{l}M \\
\Uparrow\end{array}$ & $\begin{array}{l}\text { 17.033- } \\
\text { Subfield 2- } \\
\text { NOP }\end{array}$ & \{US_Subfield:2 in 17.033$\} \mathrm{MO}$ [2 to 99] & & $\mathrm{B}^{*}$ \\
\hline & & & 1 & $\begin{array}{l}M \\
\Uparrow\end{array}$ & $\begin{array}{c}\text { 17.033- } \\
\text { Subfield } \\
\text { Pair }\end{array}$ & $\begin{array}{l}\text { For(X EQ } 3 \text { to }\{\text { US_Subfield: } 2 \text { in } 17.033\}) \\
\{ \\
\text { IF X MOD } 2 \text { EQ } 0 \\
\text { \{US_Subfield:X in RS_Subfield }\} \text { GTE } 1 \text { AND LTE } \\
\{17.007\} \\
\text { ELSE } \\
\{\text { US_Subfield:X in RS_Subfield }\} \text { GTE } 1 \text { AND LTE } \\
\{17.006\} \\
\}\end{array}$ & & $\mathrm{B}^{*}$ \\
\hline \multirow{3}{*}{$\begin{array}{l}\text { Field: } \\
\text { 17.034-Iris } \\
\text { Sclera } \\
\text { Boundary } \\
\text { Value }\end{array}$} & \multirow[t]{3}{*}{$\begin{array}{c}8.17 .30, \\
\text { Table } 71, \\
\text { Table } 16\end{array}$} & \multirow[t]{3}{*}{$\begin{array}{l}<\text { Table } 71 \text { lists the value constraints for } \\
\text { ISB.> }\end{array}$} & 1 & $\begin{array}{l}M \\
\Uparrow\end{array}$ & $\begin{array}{c}17.034- \\
\text { Subfield } 1 \text { - } \\
\text { BYC }\end{array}$ & $\{$ US_Subfield:1 in 17.034$\} \mathrm{MO}[\mathrm{ASCII}(\mathrm{C}, \mathrm{E}, \mathrm{P})]$ & & $\mathrm{B}^{*}$ \\
\hline & & & 1 & $\begin{array}{l}M \\
\Uparrow\end{array}$ & $\begin{array}{l}\text { 17.034- } \\
\text { Subfield 2- } \\
\text { NOP }\end{array}$ & \{US_Subfield:2 in 17.034$\} \mathrm{MO}$ [2 to 99] & & $\mathrm{B}^{*}$ \\
\hline & & & 1 & $\begin{array}{l}M \\
\Uparrow\end{array}$ & $\begin{array}{c}\text { 17.034- } \\
\text { Subfield } \\
\text { Pair }\end{array}$ & $\begin{array}{l}\text { For(X EQ } 3 \text { to }\{\text { US_Subfield: } 2 \text { in } 17.034\}) \\
\{ \\
\text { IF X MOD } 2 \text { EQ } 0 \\
\{\text { US_Subfield:X in RS_Subfield }\} \text { GTE } 1 \text { AND LTE } \\
\{17.007\} \\
\text { ELSE } \\
\{\text { US_Subfield:X in RS_Subfield }\} \text { GTE } 1 \text { AND LTE } \\
\{17.006\} \\
\}\end{array}$ & & $\mathrm{B}^{*}$ \\
\hline $\begin{array}{l}\text { Field: } \\
17.035-\end{array}$ & $\begin{array}{l}\text { 8.17.31, } \\
\text { Table 71, }\end{array}$ & $\begin{array}{l}<\text { Table } 71 \text { lists the value constraints for } \\
\text { UEB.> }\end{array}$ & 1 & $\begin{array}{l}M \\
\Uparrow\end{array}$ & $\begin{array}{l}17.035- \\
\text { Subfield } 1 \text { - }\end{array}$ & $\{$ US_Subfield:1 in 17.035$\} \mathrm{MO}[\mathrm{ASCII}(\mathrm{C}, \mathrm{E}, \mathrm{P})]$ & & $\mathrm{B}^{*}$ \\
\hline
\end{tabular}




\begin{tabular}{|c|c|c|c|c|c|c|c|}
\hline \multirow{3}{*}{$\begin{array}{l}\text { Upper Eyelid } \\
\text { Boundary } \\
\text { Value }\end{array}$} & \multirow{3}{*}{ Table 16} & & \multicolumn{4}{|c|}{ BYC } & \multirow[b]{2}{*}{$\mathrm{B}^{*}$} \\
\hline & & & 1 & $\begin{array}{l}M \\
\Uparrow\end{array}$ & $\begin{array}{l}\text { 17.035- } \\
\text { Subfield 2- } \\
\text { NOP }\end{array}$ & \{US_Subfield:2 in 17.035$\} \mathrm{MO}$ [2 to 99] & \\
\hline & & & 1 & $\begin{array}{l}M \\
\Uparrow\end{array}$ & $\begin{array}{l}17.035- \\
\text { Subfield } \\
\text { Pair }\end{array}$ & $\begin{array}{l}\text { For(X EQ } 3 \text { to }\{\text { US_Subfield: } 2 \text { in } 17.035\}) \\
\{ \\
\text { IF X MOD } 2 \text { EQ } 0 \\
\{\text { US_Subfield:X in RS_Subfield }\} \text { GTE } 1 \text { AND LTE } \\
\{17.007\} \\
\text { ELSE } \\
\{\text { US_Subfield:X in RS_Subfield }\} \text { GTE } 1 \text { AND LTE } \\
\{17.006\} \\
\}\end{array}$ & $\mathrm{B}^{*}$ \\
\hline \multirow{3}{*}{$\begin{array}{l}\text { Field: } \\
\text { 17.036- } \\
\text { Lower Eyelid } \\
\text { Boundary } \\
\text { Value }\end{array}$} & \multirow[t]{3}{*}{$\begin{array}{l}8.17 .32 \\
\text { Table } 71 \\
\text { Table } 16\end{array}$} & \multirow[t]{3}{*}{$\begin{array}{l}<\text { Table } 71 \text { lists the value constraints for } \\
\text { LEB.> }\end{array}$} & 1 & $\begin{array}{l}M \\
\Uparrow\end{array}$ & $\begin{array}{l}\text { 17.036- } \\
\text { Subfield } 1 \text { - } \\
\text { BYC }\end{array}$ & $\{$ US_Subfield:1 in 17.036$\} \mathrm{MO}[\mathrm{ASCII}(\mathrm{C}, \mathrm{E}, \mathrm{P})]$ & $\mathrm{B}^{*}$ \\
\hline & & & 1 & $\begin{array}{l}M \\
\Uparrow\end{array}$ & $\begin{array}{l}17.036- \\
\text { Subfield 2- } \\
\text { NOP }\end{array}$ & \{US_Subfield:2 in 17.036$\} \mathrm{MO}$ [2 to 99] & $\mathrm{B}^{*}$ \\
\hline & & & 1 & $\begin{array}{l}M \\
\Uparrow\end{array}$ & $\begin{array}{l}\text { 17.036- } \\
\text { Subfield } \\
\text { Pair }\end{array}$ & $\begin{array}{l}\text { For(X EQ } 3 \text { to }\{\text { US_Subfield:2 in } 17.036\}) \\
\{ \\
\text { IF X MOD } 2 \text { EQ } 0 \\
\{\text { US_Subfield:X in RS_Subfield }\} \text { GTE } 1 \text { AND LTE } \\
\{17.007\} \\
\text { ELSE } \\
\{\text { US_Subfield:X in RS_Subfield }\} \text { GTE } 1 \text { AND LTE } \\
\{17.006\} \\
\}\end{array}$ & $\mathrm{B}^{*}$ \\
\hline \multirow[t]{4}{*}{$\begin{array}{l}\text { Field: } \\
\text { 17.037-Non- } \\
\text { Eyulid } \\
\text { Occlusions } \\
\text { Value }\end{array}$} & \multirow[t]{4}{*}{$\begin{array}{l}8.17 .33 \\
\text { Table } 71 \\
\text { Table } 17, \\
\text { Table } 18\end{array}$} & \multirow[t]{4}{*}{$\begin{array}{l}<\text { Table } 71 \text { lists the value constraints for } \\
\text { NEO.> }\end{array}$} & 1 & $\begin{array}{l}M \\
\Uparrow\end{array}$ & $\begin{array}{l}\text { 17.037- } \\
\text { Subfield } 1 \text { - } \\
\quad \text { BYC }\end{array}$ & $\begin{array}{l}\text { ForEach(RS_Subfield in 17.037) } \\
\{ \\
\{\text { US_Subfield:1 in RS_Subfield }\} \text { MO [ASCII(T,I,L,S)] } \\
\}\end{array}$ & $\mathrm{B}^{*}$ \\
\hline & & & 1 & $\begin{array}{l}M \\
\Uparrow\end{array}$ & $\begin{array}{l}\text { 17.037- } \\
\text { Subfield 2- } \\
\text { NOP }\end{array}$ & $\begin{array}{l}\text { ForEach(RS_Subfield in 17.037) } \\
\{ \\
\{\text { US_Subfield:2 in RS_Subfield }\} \text { MO } \\
{[\text { ASCII(L,S,C,R,O)] }} \\
\}\end{array}$ & $\mathrm{B}^{*}$ \\
\hline & & & 1 & $\begin{array}{l}M \\
\Uparrow\end{array}$ & $\begin{array}{l}\text { 17.037- } \\
\text { Subfield 2- } \\
\text { NOP }\end{array}$ & $\begin{array}{l}\text { ForEach(RS_Subfield in 17.037) } \\
\{ \\
\text { \{US_Subfield:3 in RS_Subfield\} MO [ } 3 \text { to 99] } \\
\}\end{array}$ & $\mathrm{B}^{*}$ \\
\hline & & & 1 & M & 17.037- & ForEach(RS_Subfield in 17.037) & $B^{*}$ \\
\hline
\end{tabular}




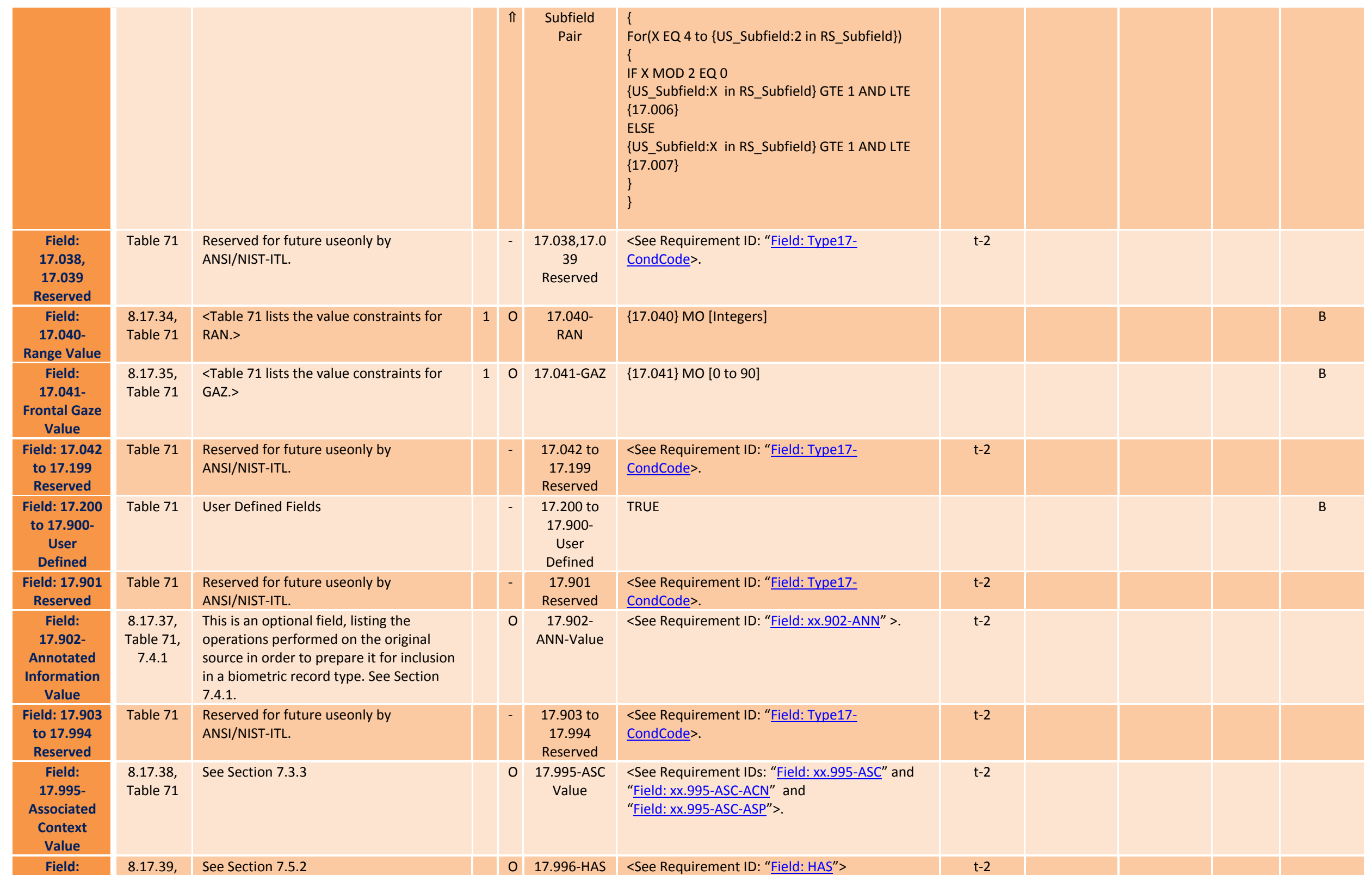




\begin{tabular}{|c|c|c|c|c|c|c|c|c|}
\hline $\begin{array}{l}\text { 17.996- } \\
\text { Hash Value }\end{array}$ & Table 71 & & & & Value & & & \\
\hline $\begin{array}{l}\text { Field: } \\
\text { 17.997- } \\
\text { Source } \\
\text { Representati } \\
\text { on Value }\end{array}$ & $\begin{array}{l}\text { 8.17.40, } \\
\text { Table } 71\end{array}$ & See Section 7.3.2 & & 0 & $\begin{array}{l}\text { 17.997-SOR } \\
\text { Value }\end{array}$ & $\begin{array}{l}\text { <See Requirement IDs: "Field: xx.997-SOR" and } \\
\text { "Field: xx.997-SOR-SRN" and } \\
\text { "Field: xx.997-SOR-RSP">. }\end{array}$ & $t-2$ & \\
\hline $\begin{array}{l}\text { Field: } \\
\text { 17.998- } \\
\text { Geographic } \\
\text { Sample } \\
\text { Acquisition } \\
\text { Location } \\
\text { Value }\end{array}$ & $\begin{array}{l}\text { 8.17.41, } \\
\text { Table } 71\end{array}$ & See Section 7.7.3 & & 0 & $\begin{array}{l}\text { 17.998- } \\
\text { GEO Value }\end{array}$ & $\begin{array}{l}\text { <See Requirement IDs: “Field: Geographic", } \\
\text { “Field: Geographic-Conditional”, “Field: } \\
\text { Geographic-Subfield 1" through “Field: } \\
\text { Geographic-Values-SubField 15” }>\text {. }\end{array}$ & $t-2$ & \\
\hline \multirow[t]{3}{*}{$\begin{array}{l}\text { Field: } \\
\text { 17.999- } \\
\text { Image Data } \\
\text { Valid }\end{array}$} & \multirow[t]{3}{*}{$\begin{array}{l}\text { 8.17.42, } \\
\text { Table } 71\end{array}$} & \multirow{3}{*}{$\begin{array}{l}\text { This is a mandatory field contains the } \\
\text { image. } \\
<\text { The image metadata is checked for } \\
\text { validity.> }\end{array}$} & 2 & $M$ & $\begin{array}{l}\text { 17.999- } \\
\text { DATA } \\
\text { Uncompres } \\
\text { sed Valid }\end{array}$ & $\begin{array}{l}\text { IF }\{17.011\} \text { EQ ASCII(NONE) THEN } \\
\text { Length(17.999) EQ } 17.006\} *\{17.007\}\end{array}$ & & B \\
\hline & & & 2 & $M$ & $\begin{array}{l}\text { 17.999- } \\
\text { DATA } \\
\text { JP2,JP2L } \\
\text { Valid }\end{array}$ & $\begin{array}{l}\text { IF }\{17.011\} \text { EQ ASCII(JP2) OR ASCII(JP2L) THEN } \\
\text { Present(SigBox, } \\
\text { HeadBox, } \\
\text { ImgBox) }\end{array}$ & $\mathrm{t}-11$ & B \\
\hline & & & 2 & $M$ & $\begin{array}{l}\text { 17.999- } \\
\text { DATA PNG } \\
\text { Valid }\end{array}$ & $\begin{array}{l}\text { IF }\{17.011\} \text { EQ ASCII(PNG) THEN } \\
\text { Present(PNGSig, } \\
\text { IHDR, } \\
\text { IDAT, } \\
\text { IEND) }\end{array}$ & $\mathrm{t}-11$ & B \\
\hline
\end{tabular}


Table C.16 - Assertions for Annex B - Traditional Encoding

\begin{tabular}{|c|c|c|c|c|c|c|c|c|c|c|c|}
\hline $\begin{array}{l}\text { Requireme } \\
\text { nt } \\
\text { ID }\end{array}$ & $\begin{array}{l}\text { Referen } \\
\text { ce in } \\
\text { Base } \\
\text { Standar } \\
\quad \text { d }\end{array}$ & $\begin{array}{l}\text { Requirement } \\
\text { Summary }\end{array}$ & $\begin{array}{l}\text { L } \\
\text { e } \\
\text { v } \\
\text { e } \\
\text { I }\end{array}$ & $\begin{array}{l}\mathrm{S} \\
\mathrm{t} \\
\mathrm{a} \\
\mathrm{t} \\
\mathrm{u} \\
\mathrm{s}\end{array}$ & $\begin{array}{l}\text { Assertion } \\
\text { ID }\end{array}$ & $\begin{array}{l}\text { Test } \\
\text { Assertion }\end{array}$ & $\begin{array}{l}\text { Test } \\
\text { Note }\end{array}$ & $\begin{array}{l}\text { Implemen } \\
\text { tation } \\
\text { Support }\end{array}$ & $\begin{array}{l}\text { Supporte } \\
\text { d Range }\end{array}$ & $\begin{array}{l}\text { Test } \\
\text { Result }\end{array}$ & $\begin{array}{l}\text { Applicab } \\
\text { ility }\end{array}$ \\
\hline \multicolumn{12}{|c|}{ Annex B: Traditional Encoding } \\
\hline $\begin{array}{l}\text { Traditional- } \\
\quad \text { Field: } \\
\text { xx.001- } \\
\text { Length, First }\end{array}$ & Annex B & $\begin{array}{l}\text { The first field in all records shall be } \\
\text { labeled as field " } 1 \text { " and contain the length } \\
\text { in bytes of the record. }\end{array}$ & & M & $\begin{array}{l}\text { Traditional: } \\
\text { xx.001- } \\
\text { Length, } \\
\text { First }\end{array}$ & $\begin{array}{l}\text { <See Requirement ID: “Field: xx.001-Record } \\
\text { Header".> }\end{array}$ & $\mathrm{t}-2$ & & & & \\
\hline $\begin{array}{l}\text { Traditional- } \\
\quad \text { Field: } \\
\mathbf{x x . 0 0 2 - I D C}\end{array}$ & Annex B & $\begin{array}{l}\text { With the exception of the Type-1 record } \\
\text { (See Section 8.1), the second field shall be } \\
\text { labeled as field Type-1 record (See ed as } \\
\text { field ueesignation character (IDC). See } \\
\text { Section 7.3.1. }\end{array}$ & & M & $\begin{array}{l}\text { Traditional: } \\
\mathrm{xx} .002-\mathrm{IDC}\end{array}$ & <See Requirement ID: “Field: xx.002-IDC".> & $t-2$ & & & & \\
\hline $\begin{array}{l}\text { Traditional- } \\
\text { Record: } \\
\text { Type1-7-bit } \\
\text { ASCII }\end{array}$ & Annex B & $\begin{array}{l}\text { The data in the Type-1 record shall always } \\
\text { be recorded in variable length fields using } \\
\text { the 7-bit American Standard Code for } \\
\text { Information Interchange (ASCII) as } \\
\text { described in ISO/IEC } 64656 \text {. For purposes } \\
\text { of compatibility, the eighth (leftmost) bit } \\
\text { shall contain a value of zero. All field } \\
\text { numbers and information separators shall } \\
\text { be recorded in 7-bit ASCII as described in } \\
\text { ISO/IEC } 646 \text {. }\end{array}$ & & M & $\begin{array}{l}\text { Traditional: } \\
\text { Type-1- } \\
\text { ASCII }\end{array}$ & <See Requirement ID: "Record: Type1-ASCII"> & $\mathrm{t}-2$ & & & & \\
\hline \multirow{3}{*}{$\begin{array}{l}\text { Traditional- } \\
\text { Field: } \\
\text { xx.001, } \\
\text { xx.002, } \\
\text { xx.999 } \\
\text { Ordered }\end{array}$} & \multirow[t]{3}{*}{ Annex B } & \multirow{3}{*}{$\begin{array}{l}\text { Textual fields in Record Types } 10-99 \text { may } \\
\text { occur in any order after the first two } \\
\text { fields and contain the information as } \\
\text { described for that particular numbered } \\
\text { field, except for field } 999 \text {, which shall be } \\
\text { the concluding field, when it is included in } \\
\text { a record. }\end{array}$} & & M & $\begin{array}{l}\text { Traditional: } \\
\text { xx.001-First }\end{array}$ & $\begin{array}{l}\text { <See Requirement ID: “Field: xx.001-Record } \\
\text { Header". }\end{array}$ & $t-2$ & & & & \\
\hline & & & & M & $\begin{array}{l}\text { Traditional: } \\
\text { xx.002- } \\
\text { Second }\end{array}$ & <See Requirement ID: “Field: xx.002-IDC".> & $\mathrm{t}-2$ & & & & \\
\hline & & & 1 & M & $\begin{array}{l}\text { Traditional: } \\
\text { xx.999-Last }\end{array}$ & $\begin{array}{l}\text { ForEach(Record in Transaction ST Type(Record) } \\
\text { NEQ } 4 \text { OR 8) } \\
\{ \\
\text { FieldNumber(Last(Field in Record)) EQ } 999 \\
\}\end{array}$ & & & & & $\mathrm{T}$ \\
\hline $\begin{array}{l}\text { Traditional- } \\
\text { Transaction: } \\
\text { Separators }\end{array}$ & $\begin{array}{l}\text { Annex B, } \\
\text { Table } 90\end{array}$ & $\begin{array}{l}\text { In the Type-1, Type-2, Type- } 9 \text { through } \\
\text { Type- } 99 \text { records, information is delimited } \\
\text { by the four ASCII information separators. } \\
\text { The delimited information may be items }\end{array}$ & 1 & M & $\begin{array}{l}\text { Traditional: } \\
\text { Separators } \\
\text { FS }\end{array}$ & $\begin{array}{l}\text { ForEach(Record in Transaction ST Type(Record) } \\
\text { MO [1,2,9 to 99]) } \\
\{ \\
\text { Last(Byte in Record) EQ 0x1C } \\
\}\end{array}$ & & & & & $\mathrm{T}$ \\
\hline
\end{tabular}




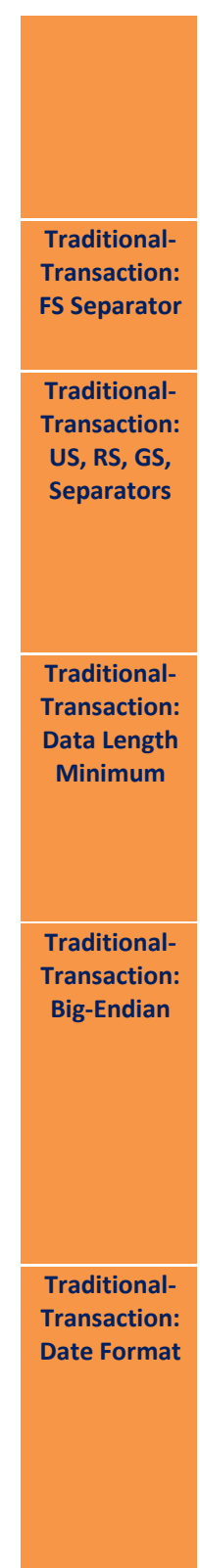

\begin{tabular}{|c|c|c|c|c|}
\hline & \multirow[t]{2}{*}{$\begin{array}{l}\text { within a field or subfield, fields within a } \\
\text { logical record, or multiple occurrences of } \\
\text { subfields. }\end{array}$} & 1 & M & $\begin{array}{l}\text { Traditional: } \\
\text { Separators } \\
\text { GS }\end{array}$ \\
\hline & & 1 & M & $\begin{array}{l}\text { Traditional: } \\
\text { Separators } \\
\text { RS,US }\end{array}$ \\
\hline Annex B & $\begin{array}{l}\text { Multiple records within a transaction are } \\
\text { separated by the "FS" character, which } \\
\text { signals the end of a logical record. }\end{array}$ & & $M$ & $\begin{array}{l}\text { Traditional: } \\
\quad \text { FS } \\
\text { Separator }\end{array}$ \\
\hline Annex B & $\begin{array}{l}\text { The "USe } x \text { Bonal-Transaction: US, RS, iple } \\
\text { items within a field or subfield; the "RShin } \\
\text { a field or subfield; the, } \\
\text { ipleSeparatorsated the } \\
\text { "GSeleSeparatorsated ated; the, } \\
\text { ipleSeparatorsa }\end{array}$ & & $M$ & $\begin{array}{l}\text { Traditional: } \\
\text { US, RS, GS } \\
\text { Separators }\end{array}$ \\
\hline B.1 & $\begin{array}{l}\text { Each information item, subfield, field, and } \\
\text { logical record shall contain one or more } \\
\text { bytes of data }\end{array}$ & 1 & $M$ & $\begin{array}{l}\text { Traditional: } \\
\text { Data } \\
\text { Length } \\
\text { Minimum }\end{array}$ \\
\hline B.1.1 & $\begin{array}{l}\text { Within a file, the order for transmission of } \\
\text { both the ASCII and the binary } \\
\text { representations of bytes shall be most } \\
\text { significant byte first and least significant } \\
\text { byte last otherwise referred to as Big- } \\
\text { Endian format. Within a byte, the order of } \\
\text { transmission shall be the most significant } \\
\text { bit first and the least significant bit last. }\end{array}$ & 2 & M & $\begin{array}{l}\text { Traditional: } \\
\text { Data Big- } \\
\text { Endian }\end{array}$ \\
\hline B.1.2 & $\begin{array}{l}\text { Dates shall appear as eight digits in the } \\
\text { format YYYYMMDD. The YYYY characters } \\
\text { shall represent the year of the } \\
\text { transaction; the MM characters shall be } \\
\text { the tens and units values of the month; } \\
\text { and the DD characters shall be the day in } \\
\text { the month. }\end{array}$ & 1 & M & $\begin{array}{l}\text { Traditional: } \\
\text { Date } \\
\text { Format }\end{array}$ \\
\hline
\end{tabular}

$<$ Not directly tested. The GS separator is used when parsing fields within a record.>

$<$ Not directly tested. The RS and US separators are used when parsing subfields and information items. $>$

<See Requirement ID: "Traditional-Transaction Separators". $>$

<See Requirement ID: "Traditional-Transaction: Separators".>

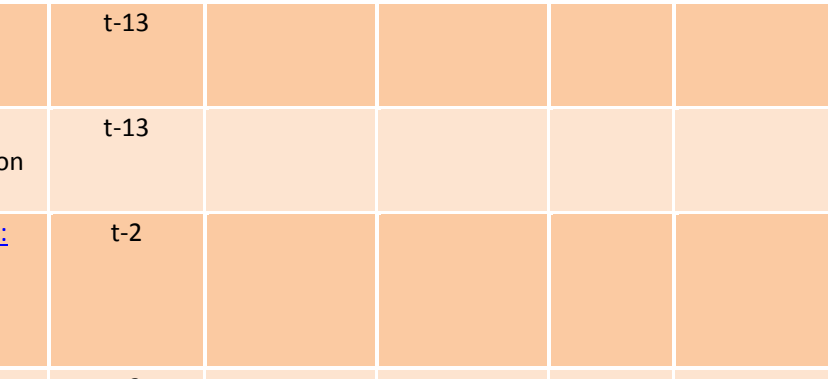

$\mathrm{t}-2$

$<$ This assertion is testing during the Character Count and Byte Length testing for each Record Type, which test for 1 byte of data at a minimum. See the following Type-10 Requirement ID's as an example: Field: Type10-CharCount and Field: Type10-Subfield CharCount .>

$<$ Not directly tested. However, the parsing methods use the Big-Endian format when processing transactions.>

$<$ This assertion is tested for each field or subfield that requires a date entry. For example, see

Requirement ID "Field: 1.005-Local Date Value".

$\mathrm{t}-2$
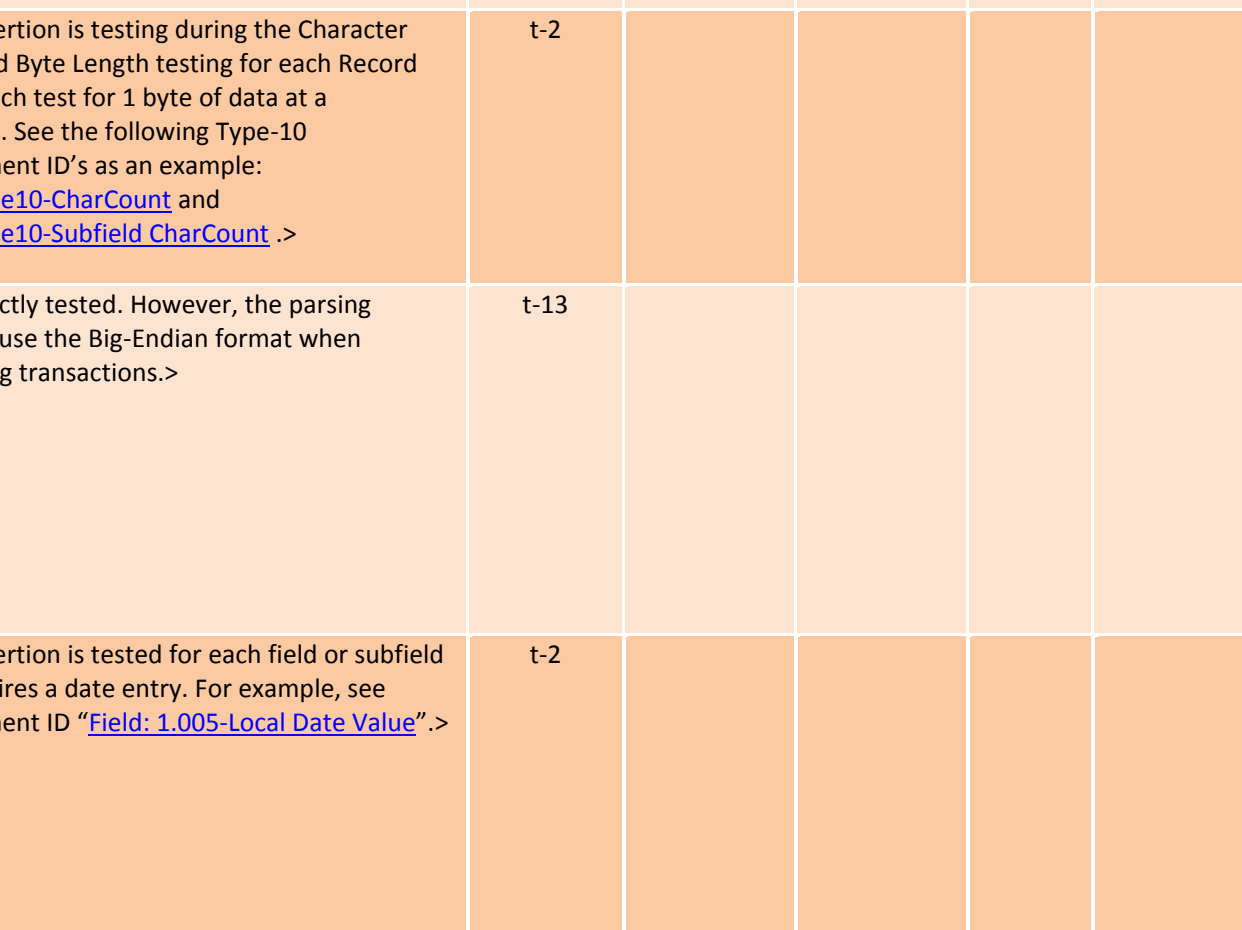


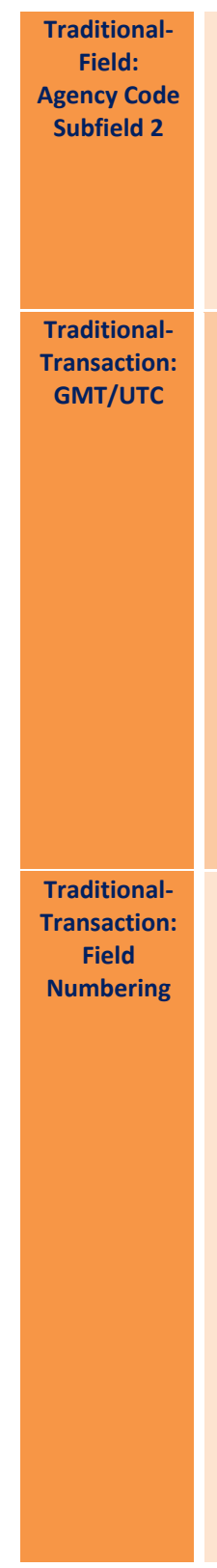

B.1.3 The 2007 version of the standard included only the first information item in agency code fields (See Section 7.6). New to this version, a second, optional, information item is allowed in Traditional encoding in order to maintain consistency with the 2008 version of the standard.

B.1.4 GMT/UTC shall be represented as YYYYMMDDHHMMSSZ, a 15-character string that is the concatenation of the date with the time and concludes with the character nal enco

YYYY characters shall represent the year of the transaction. The MM characters shall be the tens and units values of the month. The DD characters shall be the tens and units values of the day of the month. The HH characters represent the hour; the MM the minute; and the SS represents the second.

B.1.5 For the Type-1, Type-2, Type-9 through Type- 99 records, each information field that is used shall be numbered in accordance with this standard. The format for each field shall consist of the logical record type number followed by a period rmat for each field followed by a colon al record type number followed by a pepriate to that field. The field number may be any one to nine-digit number occurring between the period field. The colon may be any one to nine-digit number occurring betweeneld number. This implies that a field number of $y$ one to nine-digit numberand shall be interpreted in the same manner as a field number of " 2.000000123 :.
M Traditional: <See Requirement ID: "Field: Agency Codes".> Agency

Code

Subfield 2

M Traditional: GMT/UTC

$<$ This assertion is tested for each field or subfield that requires a GMT/UTC entry. For example, see Requirement ID "Field: Geographic-Subfield 1".>

\section{M Traditional:}

Field

$<$ Not directly tested. However, the parsing methods use the described format when

Numbering processing transactions.>

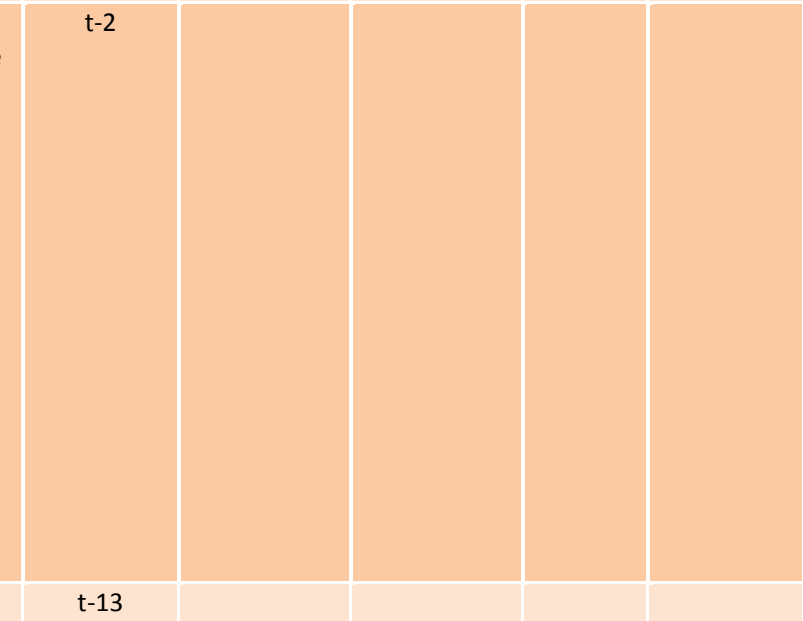




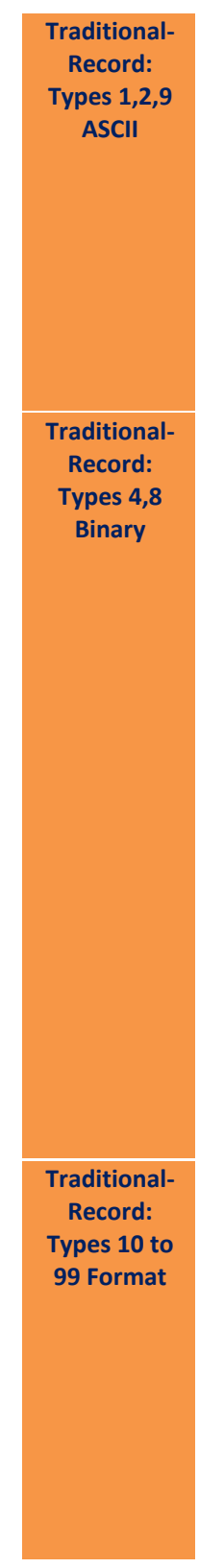

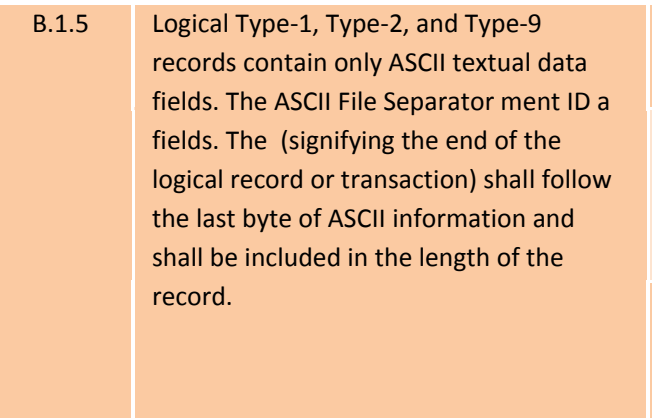

B.1.5 The Record Type-4: Grayscale fingerprint image and the Record Type-8: Signature image record contain only binary data recorded as ordered fixed-length binary fields. The entire length of the record shall be recorded in the first four-byte binary field of each record. For these binary records, neither the record number with its period, nor the field identifier number and its following colon, shall be recorded. Furthermore, as all the field lengths of these six records are either fixed and specified, none of the four separato characters ("US", "RS"," GS", or "FS") shall be interpreted as anything other than binary data. For these binary records, the "FS" character shall not be used as a record separator or transaction terminating character.

B.1.5 The Type-10 through Type-99 records combine ASCII fields with a single binary sample field. Each ASCII field contains a numeric field identifier and its descriptive data. When Field 999 is present in a record it shall appear as the last entry in the record and shall contain the data placed immediately following the colon (er and its descriptive data. When record length field shall contain the length of the
M Traditional: Type1-

1 M Traditional: ForEach(Field in Record ST Type(Record) EQ 2 OR ASCII

\{Bytes(Field)\} MO [0x02, 0x03, 0x1C to 0x7E]

M Traditional: <See Requirement ID: "Traditional-Transaction: Separators".>

Types

$1,2,9-\mathrm{FS}$

Separator

M Traditional: Type4Binary

M Traditional:

Type8-

Binary

The test assertions for this type may not be supported in this version of the CTM. If they are supported, they are included under field testing for Record Type-8: Signature image record.>

M Traditional:

<See Requirement ID: "Traditional-Field: xx.001

Types 10 to

SSee Requirement ID. "Field. Type4-CharType" > 99, xx.999 las

M Traditional: Types 10 to 99, Record Length

M Traditional: <See Requirement ID: "Traditional-Transaction: Types 10 to Separators".> 99, FS Separator $\mathrm{t}-2$

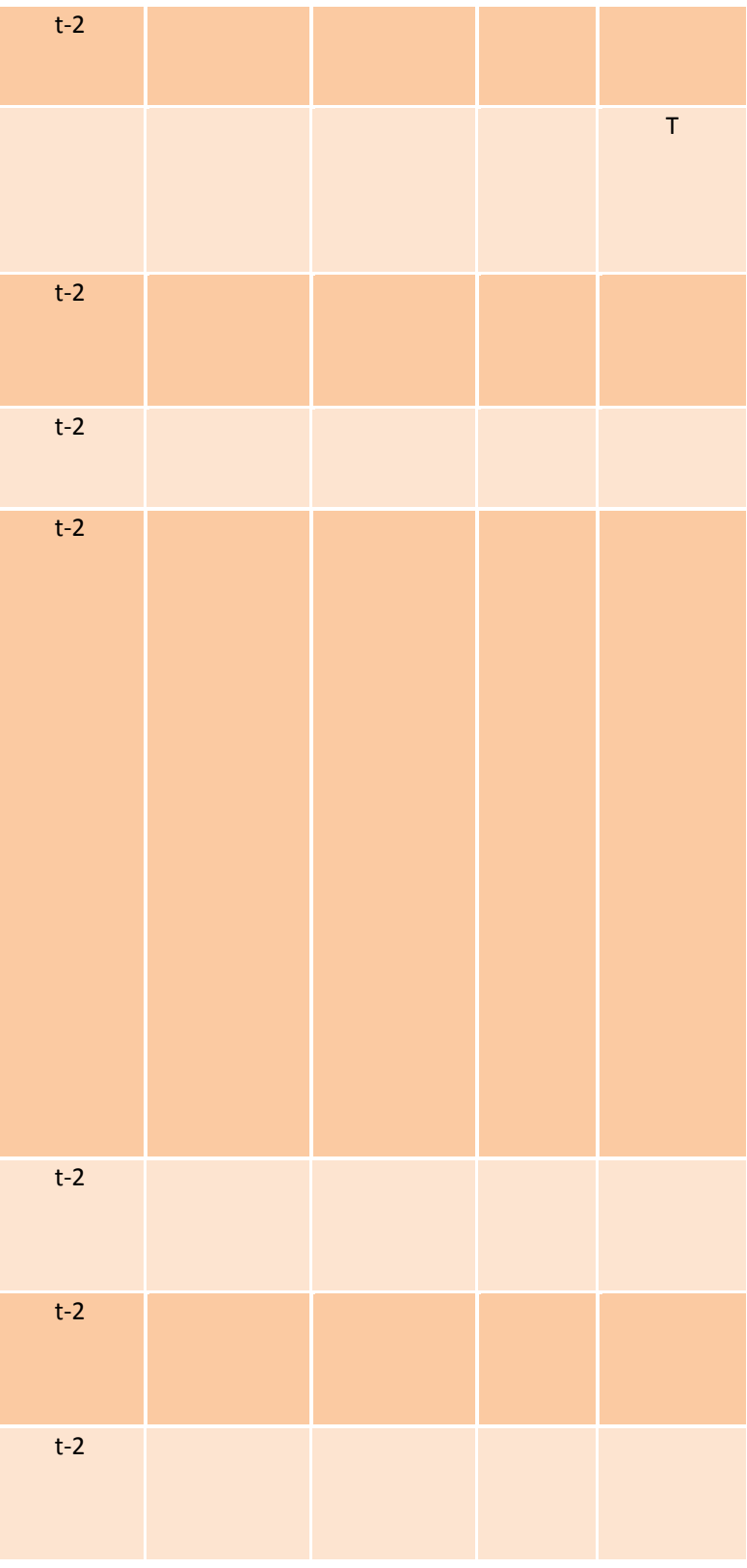



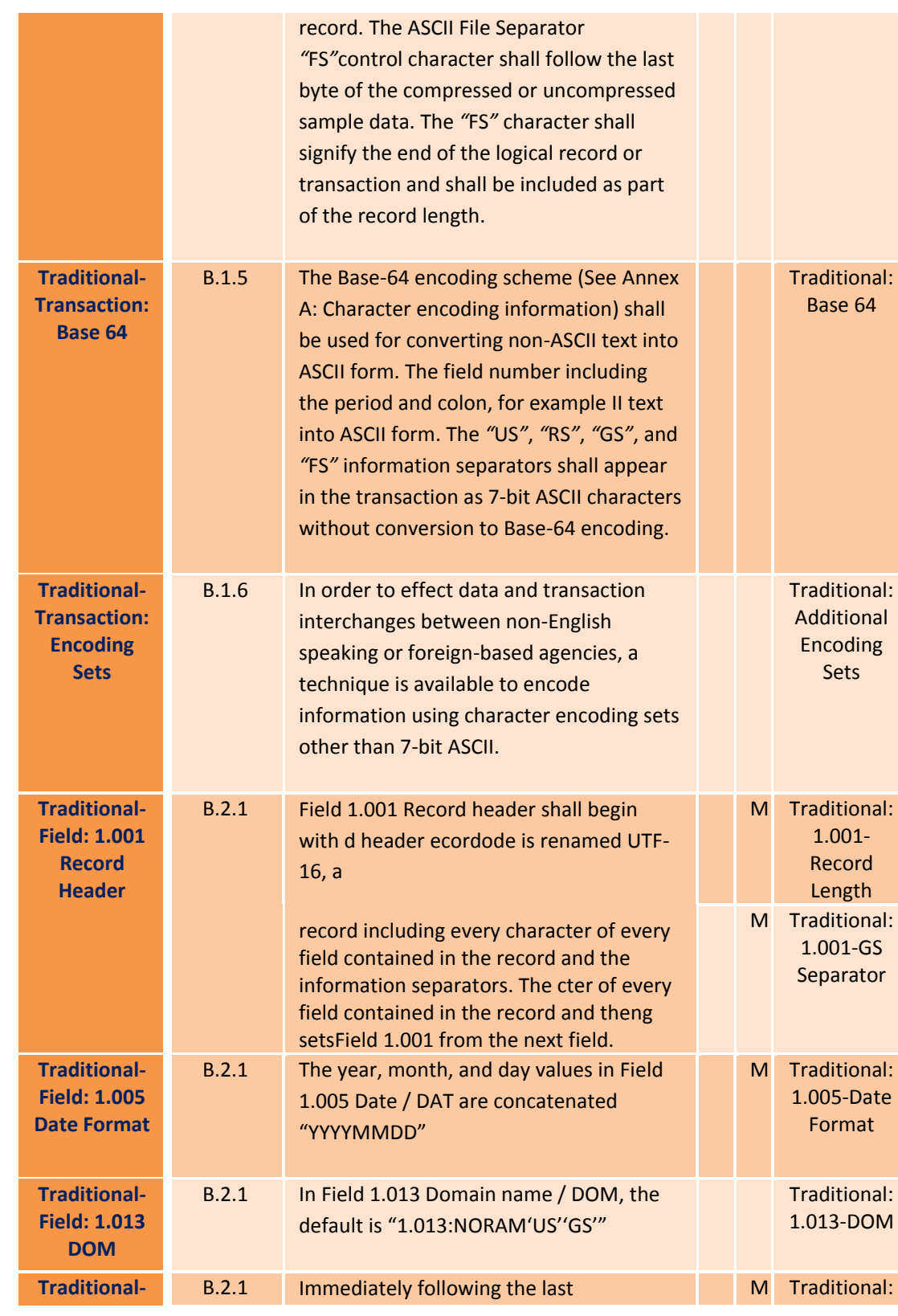

B.2.1 Immediately following the last

M Traditional:

$$
1.001
$$$$
\text { Record }
$$$$
\text { Length }
$$

M Traditional:

1.001-GS

record including every character of every field contained in the record and the information separators. The cter of every field contained in the record and theng setsField 1.001 from the next field.

B.2.1 The year, month, and day values in Field 1.005 Date / DAT are concatenated "YYYYMMDD"

B.2.1 In Field 1.013 Domain name / DOM, the default is "1.013:NORAM'US"GS"

$$
\begin{aligned}
& \text { 1.001-GS } \\
& \text { Separator }
\end{aligned}
$$

M Traditional: 1.005-Date Format

Traditional: 1.013-DOM

M Traditional:

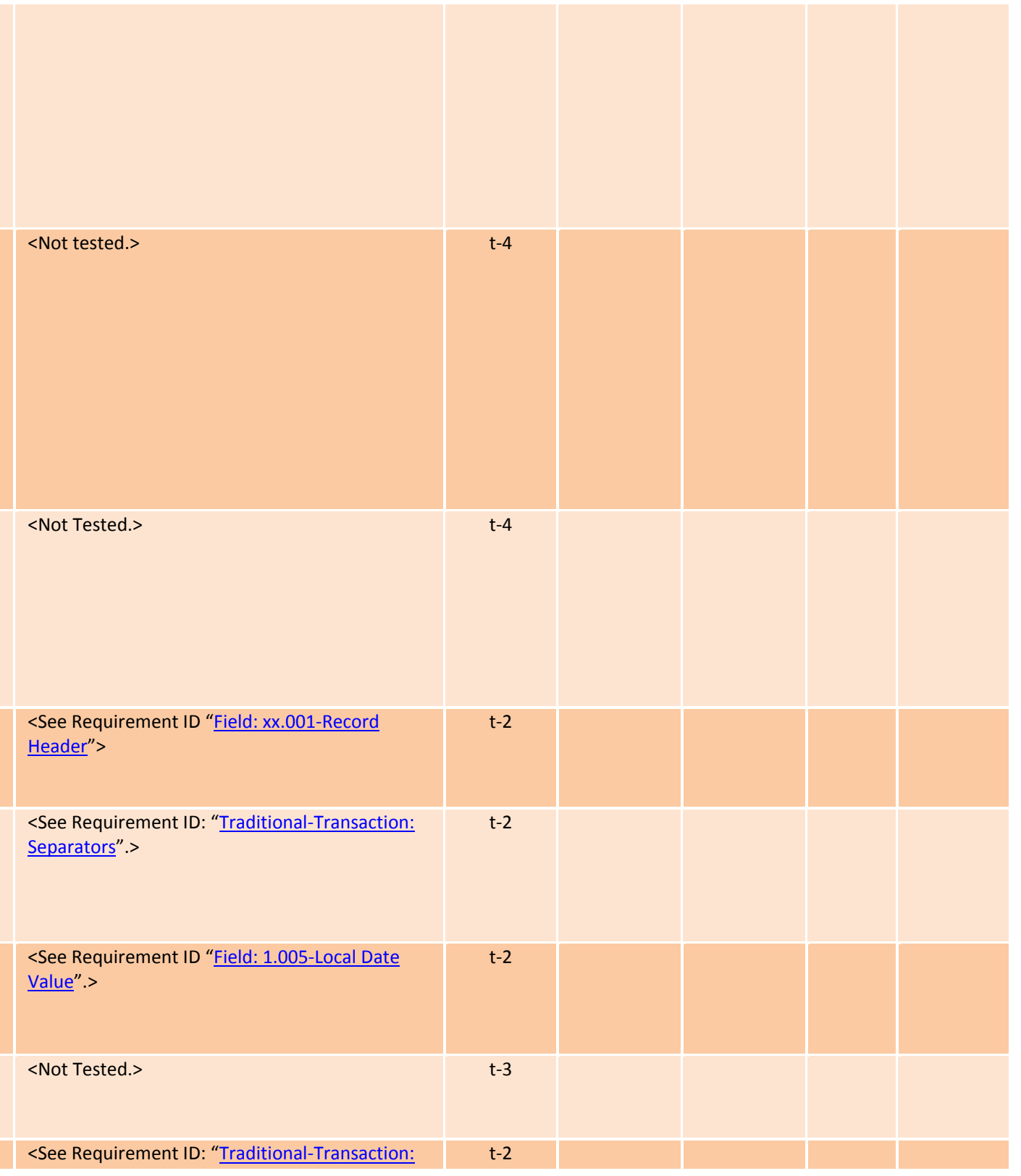




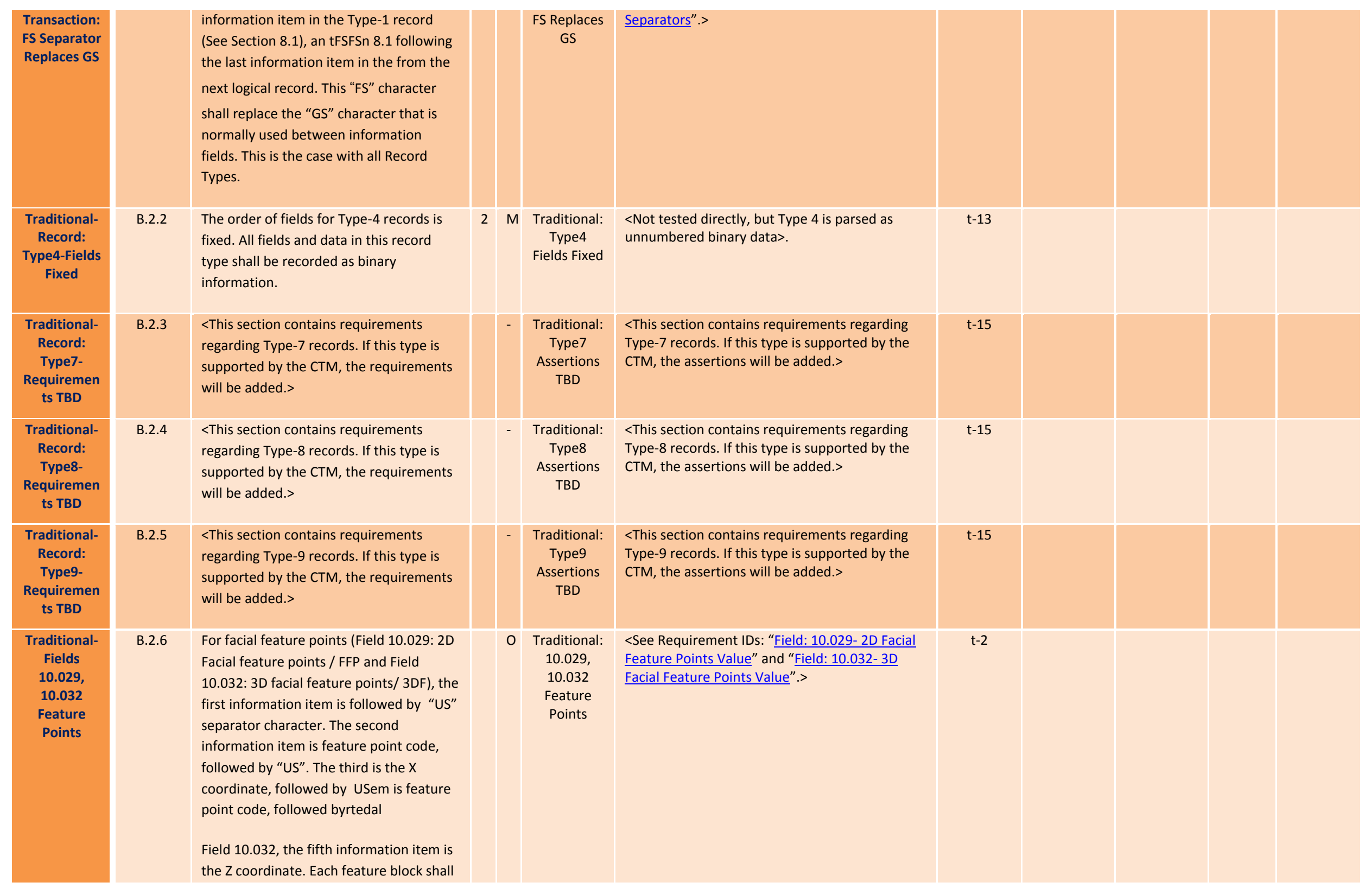




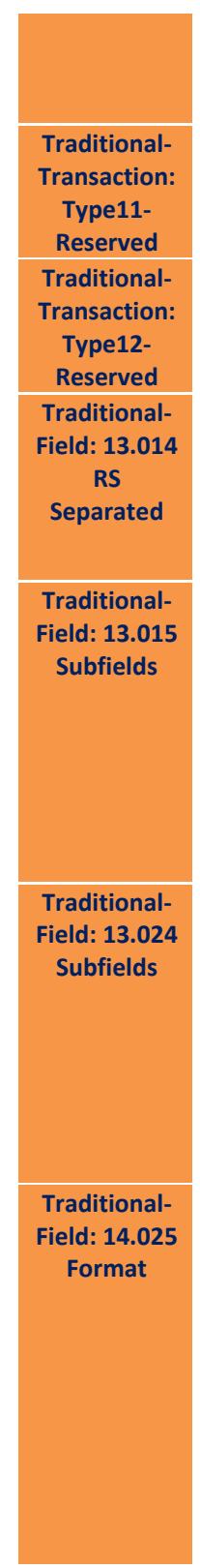

\begin{tabular}{|l|l|}
\hline & $\begin{array}{l}\text { be separated by the tRSn item is the Z } \\
\text { coordi }\end{array}$ \\
\hline B.2.7 & $\begin{array}{l}\text { This Record Type is reserved for future } \\
\text { use as Voice data. }\end{array}$ \\
\hline B.2.8 & $\begin{array}{l}\text { This Record Type is reserved for future } \\
\text { use as Dental data. }\end{array}$ \\
\hline B.2.9 & $\begin{array}{l}\text { For Field 13.014: Search position } \\
\text { descriptors / SPD, multiple portions of the } \\
\text { EJI may be listed and separated by the } \\
\text { "RS" character. }\end{array}$ \\
\hline B.2.9 & $\begin{array}{l}\text { For Field Field 13.015: Print position } \\
\text { coordinates / PPC, the six information } \\
\text { items within the field are separated by } \\
\text { five sUS PPCDDental data.SUblock shall } \\
\text { belowed by tedal definitions may be } \\
\text { repeated as subfields separated by the } \\
\text { dRSblock shall }\end{array}$ \\
\hline B.2.10 & $\begin{array}{l}\text { Field 14.025: Alternate finger segment } \\
\text { position(s) / ASEG shall consist of one to } \\
\text { four subfields. Each subfield shall consist } \\
\text { of a finger number between } 1 \text { and } 10, \text { or } \\
\text { 16 or 17; the total number of vertices of } \\
\text { the polygon encompassing the finger; and } \\
\text { the set of consecutive vertices. Each } \\
\text { vertex shall be represented as horizontal } \\
\text { and vertical pixel offsets relative to the } \\
\text { origin positioned in the upper left corner }\end{array}$ \\
\hline B.2.9 & $\begin{array}{l}\text { Field Field 13.024: Latent quality metric / } \\
\text { LQM may contain one or more subfields, } \\
\text { each consisting of four information items } \\
\text { separated by the"Us" character. The } \\
\text { subfield may be repeated for each latent } \\
\text { image and quality algorithm used, } \\
\text { separated by the "RS" character. }\end{array}$ \\
\hline
\end{tabular}

M Traditional:

Type11Reserved

M Traditional:

Type12-

Reserved

M Traditional:

13.014-RS

Separated

M Traditional:

13.015-

Subfields

See Requirement ID: "Transaction: Reserved

Records". .

<See Requirement ID: "Transaction: Reserved

Records".>

SSee Requirement ID:

"Field: SPD,PPD Values .>

$<$ See Requirement ID:

"Field: PPC-Subfield Occurrences". .>

$\mathrm{t}-2$

M Traditional:

13.024-

Subfields

Occurrences" to

"Field: Sample Quality Additional Subfield".>

M Traditional:

14.025-

Finger Sement ID: "Field: 14.025-Alternate

Finger Segment Position(s) Value" and "Field:

Format Type14-Subfield Occurrence". $>$ 


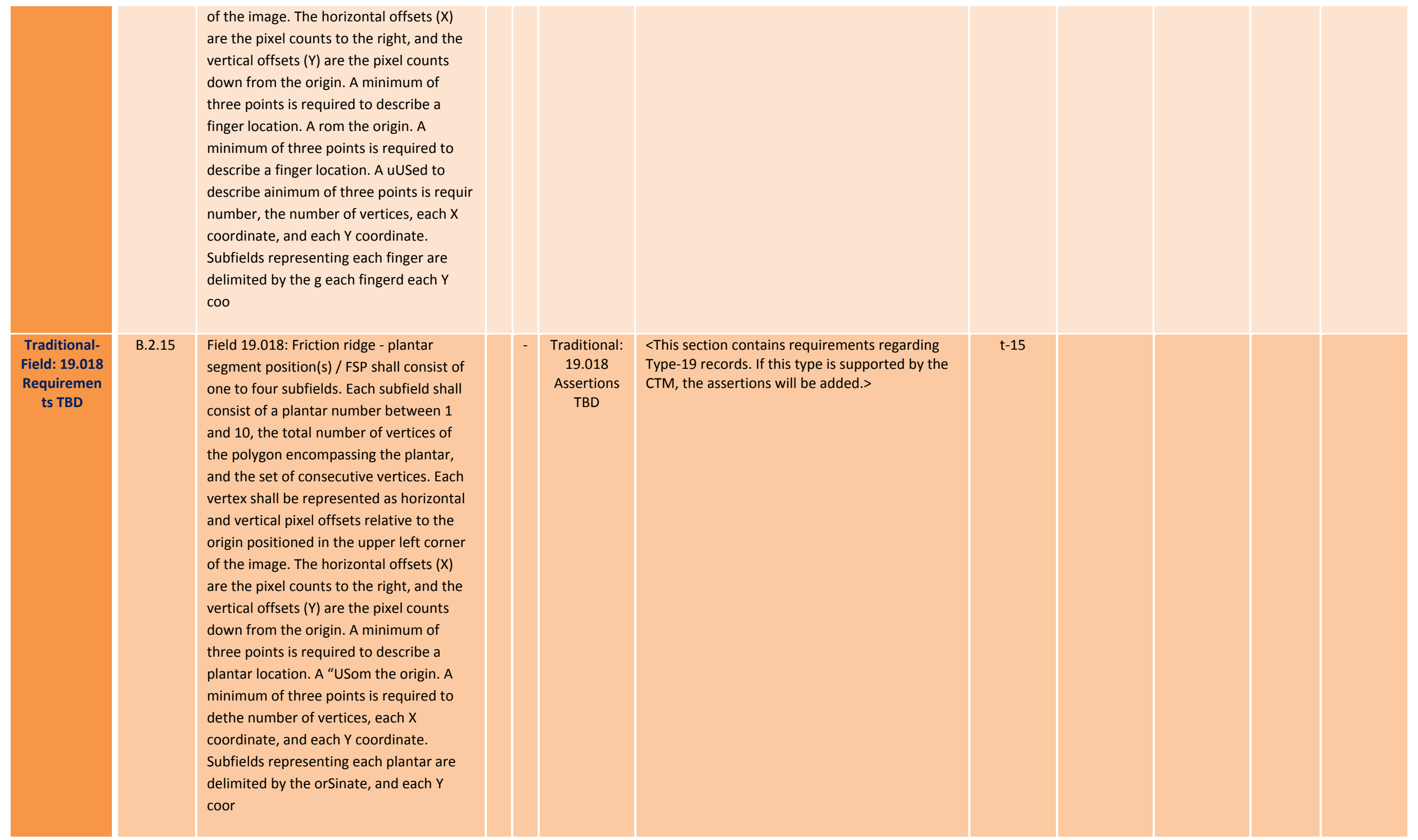




\section{C.4 Test Notes}

The following test notes provide clarification of the assertion text included in the Test Assertion columns. The test notes contain various types of information including:

- Additional information to help clarify complex assertions such as image metadata and IDC comparisons.

- Explanations of decisions made when the base standard is not clear or contains possible discrepancies.

- "Exception" which refers to any AN-2011 requirement that does not have an associated assertion defined in this document.

t-1. Semantic (Level 3) assertions are not included in the tables except to intentionally clarify that the assertion is L3. An explanation may be given explaining why the assertion is considered L3.

$\mathrm{t}-2$. The assertions for this requirement are listed in another section of a table as described in the "Test Assertion" column.

t-3. Assertions related to Domain Names and Application Profile Specifications are not addressed in the tables.

t-4. Assertions related to Character Sets other than 7-bit ASCII or binary are not addressed in the tables.

t-5. Refer to the IDC tables below to determine the test output based upon the types being compared for matching IDCs.

\section{Table C-16 - IDC ID Location Comparison}

\begin{tabular}{|l|l|l|l|}
\hline \multicolumn{4}{|c|}{ IDC: ID Location Comparison } \\
\hline Record Type & Field 10.003 & Biometric & Field For Comparison ID \\
\hline $\mathbf{4}$ & NA & FINGER & Byte 1 of 4.004 \\
\hline $\mathbf{1 0}$ & FACE & FACE & NA \\
\hline $\mathbf{1 0}$ & SCAR & SCAR & $(1,1)$ of 10.040 \\
\hline $\mathbf{1 0}$ & MARK & MARK & $(1,1)$ of 10.040 \\
\hline $\mathbf{1 0}$ & TATTOO & TATTOO & $(1,1)$ of 10.040 \\
\hline $\mathbf{1 3}$ & NA & FINGER & $(1,1)$ of 13.013 \\
\hline $\mathbf{1 4}$ & NA & FINGER & $(1,1)$ of 14.013 \\
\hline $\mathbf{1 7}$ & NA & IRIS & 17.003 IF $17.003=1$ Or 2 \\
\hline
\end{tabular}

Table C-17 - IDC Comparison Results

\begin{tabular}{|l|l|l|l|}
\hline \multicolumn{4}{|c|}{ IDC: Comparison Results } \\
\hline First Record & Second Record & Comparison IDs & Result \\
\hline FINGER & FINGER & Same & Ok \\
\hline FINGER & FINGER & Different & Error \\
\hline
\end{tabular}




\begin{tabular}{|l|l|l|l|}
\hline FINGER & NEQFINGER & NA & Error \\
\hline FACE & FACE & NA & Ok \\
\hline FACE & NEQ FACE & NA & Error \\
\hline IRIS & IRIS & $\begin{array}{l}\text { Both }=1 \text { Or Both } \\
=2\end{array}$ & Ok \\
\hline IRIS & IRIS & $\begin{array}{l}\text { Not Both }=1 \text { Or } \\
\text { Both }=2)\end{array}$ & Error \\
\hline SCAR & NEQ IRIS & NA & Error \\
\hline SCAR & SCAR & Same & Ok \\
\hline SCAR & $\begin{array}{l}\text { MARK Or } \\
\text { TATTOO }\end{array}$ & Different & Warning \\
\hline SCAR & $\begin{array}{l}\text { FINGER, } \\
\text { FACE Or IRIS }\end{array}$ & NA & Warning \\
\hline MARK & MARK & Same & Error \\
\hline MARK & MARK & Different & Ok \\
\hline MARK & $\begin{array}{l}\text { SCAR Or } \\
\text { TATTOO }\end{array}$ & Same or Different & Warning \\
\hline MARK & $\begin{array}{l}\text { FINGER, } \\
\text { FACE Or IRIS }\end{array}$ & NA & Error \\
\hline TATTOO & TATTOO & Same & Ok \\
\hline TATTOO & TATTOO & Different & Warning \\
\hline TATTOO & $\begin{array}{l}\text { SCAR Or } \\
\text { MARK }\end{array}$ & Same or Different & Warning \\
\hline FACE Or IRIS & NA & Error \\
\hline
\end{tabular}

t-6. UTC has replaced GMT. Date and time are defined in section 7.7.2 of the standard. The set of values ValidUTC/GMT is described in section 7.7.2.2 of the standard and is always less than the current date and time. ValidUTC/GMT is in the form YYYYMMDDHHMMSSZ; NIEM-ValidUTC/GMT is in the form YYYY-MM-DDThh:mm:ssZ. The ValidLocalDate is in the form YYYYMMDD; NIEM-ValidLocalDate is in the form YYYY-MM-DD.

t-7. Assertions for alternate coordinate systems are not included in the tables.

t-8. Refer to http://earth-info.nga.mil/GandG/coordsys/grids/utm.html to determine valid values for the band of latitude and grid zone. There are possible discrepancies in the AN-2011 standard regarding the $10^{\text {th }}$ information item for field xx.998. While the standard states that the coordinates are UTM (defined only for the area between 84N and 80S), it also allows values outside of UTM. 
However, allowing these extraneous values which are valid in UPS causes problems with the formatting such as the band of latitude, which doesn't exist for those values. Therefore, this draft of the AN-2011 Assertion Tables does not allow values A,B,Y, and Z for the $10^{\text {th }}$ information item.

t-9. L2 and L3 assertions associated with SAP, FAP, and IAP are not included in the tables. Some of the assertions, such as determining the conditions under which the samples were collected to ensure the SAP, FAP, or IAP levels, are not feasible to test at this time.

$\mathrm{t}-10$. IBIA Vendor Registry is a registry of CBEFF Biometric Organizations that map the value QAV to a registered organization. The assertions will accept any values, as the standard does not require that the value be registered with IBIA.

t-11. All image-related assertions associated with compressed image types are tested against the image metadata only and not against the image itself. Features of each of the image type's metadata are defined in the "Image Metadata" table below. Combining the "Term" with the "Image Type" gives the specific implementation. For example, $\{$ Image Height-PNG $\}$ is equivalent to " 2 nd parameter of the IHDR chunk". Also, IHDR means Image Header Chunk, so the full definition becomes " $2^{\text {nd }}$ parameter of the Image Header Chunk in a PNG image.” Note that for NIEM encoding, the image data must first be converted from Base-64.

Table C-18 - Image Metadata

\begin{tabular}{|c|c|c|}
\hline & & Image Metadata \\
\hline Term & Image Type(s) & Implementation \\
\hline \multirow{4}{*}{ Image Width } & JPEG, JPEGL & $4^{\text {th }}$ parameter of the Frame Header not counting the SOF marker \\
\hline & JP2, JP2L & $2^{\text {nd }}$ parameter of Image Header box \\
\hline & PNG & $1^{\text {st }}$ parameter of IHDR chunk \\
\hline & WSQ & $5^{\text {th }}$ parameter of SOF not counting the SOF marker \\
\hline \multirow{4}{*}{ Image Height } & JPEG, JPEGL & $3^{\text {rd }}$ parameter of the Frame Header not counting the SOF marker \\
\hline & JP2, JP2L & $1^{\text {st }}$ parameter of Image Header box \\
\hline & PNG & $2^{\text {nd }}$ parameter of IHDR chunk \\
\hline & WSQ & $4^{\text {th }}$ parameter of SOF not counting the SOF marker \\
\hline \multirow{4}{*}{ Sampling Units } & JPEG, JPEGL & $4^{\text {th }}$ parameter in JFIF Header not counting the APP0 Marker \\
\hline & JP2, JP2L & Undefined \\
\hline & PNG & $3^{\text {rd }}$ parameter of PHYS chunk \\
\hline & WSQ & Undefined \\
\hline \multirow{4}{*}{ Horizontal Density } & JPEG, JPEGL & $5^{\text {th }}$ parameter in JFIF Header not counting the APP0 Marker \\
\hline & JP2, JP2L & Undefined \\
\hline & PNG & $1^{\text {st }}$ parameter in PHYS Chunk \\
\hline & WSQ & Undefined \\
\hline \multirow{2}{*}{ Vertical Density } & JPEG, JPEGL & $6^{\text {th }}$ parameter in JFIF Header not counting the APP0 Marker \\
\hline & JP2, JP2L & Undefined \\
\hline
\end{tabular}




\begin{tabular}{|c|c|c|}
\hline & PNG & $2^{\text {nd }}$ parameter in PHYS Chunk \\
\hline & WSQ & Undefined \\
\hline \multirow{4}{*}{ BPX } & JPEG, JPEGL & 2nd parameter of the Frame Header not counting the SOF marker \\
\hline & JP2, JP2L & 7 LSB of $4^{\text {th }}$ parameter of ImgBox +1 if $4^{\text {th }}$ parameter of ImgBox is not 255 \\
\hline & PNG & $3^{\text {rd }}$ parameter of IHDR chunk \\
\hline & WSQ & Undefined \\
\hline \multirow{4}{*}{ CSP } & JPEG, JPEGL & Undefined \\
\hline & JP2, JP2L & $4^{\text {th }}$ parameter of Colour Specification box \\
\hline & PNG & $4^{\text {th }}$ parameter of IHDR chunk \\
\hline & WSQ & Undefined \\
\hline Encoder Version & WSQ & $10^{\text {th }}$ parameter of SOF not counting the SOF marker \\
\hline \multirow{2}{*}{ SOI } & JPEG, JPEGL & Start of JPEG type image. \\
\hline & WSQ & Start of WSQ image. \\
\hline \multirow{2}{*}{ SOF } & JPEG, JPEGL & Start of frame in a JPEG type image. \\
\hline & WSQ & Start of WSQ image. \\
\hline \multirow{2}{*}{ EOI } & JPEG, JPEGL & End of a JPEG type image. \\
\hline & WSQ & End of WSQ image. \\
\hline SOB & WSQ & Start of block in a WSQ image. \\
\hline SigBox & JP2,JP2L & Signature Box that marks the start of a JP2 type image. \\
\hline HeadBox & JP2,JP2L & Header Box in a JP2 type image. \\
\hline ImgBox & JP2, JP2L & Image Header Box in a JP2 type image. \\
\hline PNGSig & PNG & Signature of a PNG image. \\
\hline IHDR & PNG & Image Header Chunk in a PNG image. \\
\hline IDAT & PNG & Image Data Chunk in a PNG image. \\
\hline IEND & PNG & Image End Chunk in a PNG image. \\
\hline JFIF Header & JPEG, JPEGL & Frame for specifying JPEG type image metadata. Its inclusion is required by the standard. \\
\hline PHYS Chunk & PNG & An optional Chunk in a PNG image that may be used if present to verify image attributes. \\
\hline
\end{tabular}

$\mathrm{t}-12$. The image metadata required to implement the assertion is not defined in the image standard documentation.

$\mathrm{t}-13$. The assertion is addressed during parsing.

$\mathrm{t}-14$. Further research is needed to determine the feasibility of testing for ASEG requirements related to the polygon structure.

$\mathrm{t}-15$. These requirements are related to record types currently not supported.

t-98. There are some discrepancies in the $4^{\text {th }}$ draft of the standard regarding compression algorithms for various record types. For Type-

4 records, Table 21 and section 8.4 .8 state that the value can be 0 to 6 (any compression algorithm) while section 8.4 states that

"All images shall be compressed using WSQ". The assertions only allow WSQ and uncompressed types (values 0 and 1 ). For 
Type 10, section 7.7.9.3 does not define which compression algorithms are valid for facial images. The assertions allow all compression algorithms (except WSQ) for facial images. For Types 13 and 14, section 7.7.9.1 indicates that WSQ shall be used for grayscale friction ridges at $500 \mathrm{ppi}$. It does not specify if any other types may be used. Also, section 5.3.13 specifies that Type-13 should only allow uncompressed and lossless compression. The assertions will support WSQ and lossless for Type 13, and will allow any compression for Type 14. For Type 17, the section 7.7.9.2 clearly states that the baseline JPEG algorithm may not be used. The assertions will support compression algorithms specified by Table 71: NONE, PNG, JP2, and JP2L. The assertions will be modified later on according to the content of the $5^{\text {th }}$ draft.

t-99. Further research is needed to determine the assertions required to test for conformance to this requirement. 
Annex D: Exceptions Table

An "exception" refers to any AN-2011 requirement that does not have an associated assertion defined in this document. Table C.1 identifies and provides justification for all exceptions present in the tables.

\section{Table D.1 - Exceptions Table}

\begin{tabular}{|c|c|c|c|}
\hline Exception & Section & Requirement Summary & Justification \\
\hline \multirow[t]{2}{*}{$\begin{array}{c}\text { Domain } \\
\text { Names / } \\
\text { Application } \\
\text { Profile } \\
\text { Specifications }\end{array}$} & 5.3 .2 & $\begin{array}{l}\text { Data contained in this record shall conform in format and content to the } \\
\text { specifications of the domain name(s) as listed in Field } 1.013 \text { Domain name / DOM } \\
\text { found in the Type-1 record, if that field is in the transaction. The default domain is } \\
\text { NORAM. Field } 1.016 \text { Application profile specifications / APS allows the user to } \\
\text { indicate conformance to multiple specifications. If Field } 1.016 \text { is specified, the } \\
\text { Type- } 2 \text { record must conform to each of the application profiles. } \\
\text { A DOM or APS reference uniquely identifies data contents and formats. Each } \\
\text { domain and application profile shall have a point of contact responsible for } \\
\text { maintaining this list. The contact shall serve as a registrar and maintain a } \\
\text { repository including documentation for all of its common and user-specific Type-2 } \\
\text { data fields. As additional fields are required by specific agencies for their own } \\
\text { applications, new fields and definitions may be registered and reserved to have a } \\
\text { specific meaning. When this occurs, the domain or application profile registrar is } \\
\text { responsible for registering a single definition for each number used by different } \\
\text { members of the domain or application profile. }\end{array}$ & $\begin{array}{l}\text { The format and content of the } \\
\text { record are defined by the DOM } \\
\text { or APS. Each DOM and APS has } \\
\text { related record-content definitions } \\
\text { that may be updated. The } \\
\text { evolving nature of the DOM and } \\
\text { APS definitions and nature of } \\
\text { using registrars makes testing for } \\
\text { conformance via the CTS very } \\
\text { difficult. }\end{array}$ \\
\hline & 6 & $\begin{array}{l}\text { An implementation domain, coded in Field } 1.013 \text { Domain name / DOM of a Type- } \\
1 \text { record as an optional field, is a group of agencies or organizations that have } \\
\text { agreed to use preassigned data fields with specific meanings (typically in Record } \\
\text { Type-2) for exchanging information unique to their installations. The } \\
\text { implementation domain is usually understood to be the primary application profile } \\
\text { of the standard. } \\
\text { New to this version of the standard, Field } 1.016 \text { Application profile specifications / } \\
\text { APS allows multiple application profiles to be referenced. The organization } \\
\text { responsible for the profile, the profile name and its version are all mandatory for } \\
\text { each application profile specified. A transaction must conform to each profile that } \\
\text { is included in this field. It is possible to use Field } 1.016 \text { and / or Field } 1.013 \text {. }\end{array}$ & $\begin{array}{l}\text { Since the "transaction must } \\
\text { conform to each profile" } \\
\text { included in the field, and those } \\
\text { profiles are defined by the listed } \\
\text { agency, the CTS would have to } \\
\text { retrieve the latest requirements } \\
\text { from the agency. } \\
\text { Also, testing that all specified } \\
\text { DOM and APS have the same } \\
\text { definitions for fields, subfields, } \\
\text { and information items is not }\end{array}$ \\
\hline
\end{tabular}




\begin{tabular}{|c|c|c|c|}
\hline & & $\begin{array}{l}\text { A specified implementation domain and specified application profiles must all } \\
\text { have the same definition for fields, subfields and information items that are } \\
\text { contained in the transaction. }\end{array}$ & feasible. \\
\hline $\begin{array}{l}\text { Alternate } \\
\text { Character } \\
\text { Sets }\end{array}$ & $\begin{array}{c}5.6 \\
\text { Table } 2\end{array}$ & $\begin{array}{l}\text { Field 1.015 Character encoding/DCS is an optional field that allows the user to } \\
\text { specify an alternate character encoding... Field } 1.015 \text { Character encoding/DCS } \\
\text { contains three information items: the character encoding set index/ CSI, the } \\
\text { character encoding sent name/CSN, and the character encoding set version/CSV. } \\
\text { The first two items are selected from the appropriate columns of Table } 2 \text {. }\end{array}$ & $\begin{array}{l}\text { Table } 2 \text { lists ASCII, UTF-16, } \\
\text { UTF-8, and UTF-32 as possible } \\
\text { encodings. However, the table } \\
\text { also allows "User-defined" } \\
\text { character encoding sets. Testing } \\
\text { for conformance to user-defined } \\
\text { character encoding sets is not } \\
\text { feasible for the CTS. Further } \\
\text { research is needed to support } \\
\text { Character sets other than 7-bit } \\
\text { ASCII. }\end{array}$ \\
\hline \multirow[b]{2}{*}{$\begin{array}{c}\text { Alternate } \\
\text { Coordinate } \\
\text { System }\end{array}$} & $\begin{array}{c}7.7 .3 \\
\text { Table } 4\end{array}$ & $\begin{array}{l}\text { The ninth information item is the geodetic datum code / GDC10. It is an } \\
\text { alphanumeric value of } 3 \text { to } 6 \text { characters in length. This information item is used to } \\
\text { indicate which coordinate system was used to represent the values in information } \\
\text { items } 2 \text { through } 7 \text {. If no entry is made in this information item, then the basis for } \\
\text { the values entered in the first eight information items shall be WGS84, the code } \\
\text { for the World Geodetic Survey } 1984 \text { version - WGS } 84 \text { (G873). See Table } 4 \text { for } \\
\text { values. }\end{array}$ & $\begin{array}{l}\text { Table } 4 \text { lists } 22 \text { coordinate } \\
\text { systems and the option to include } \\
\text { "Other" types as well. It is not } \\
\text { feasible for the CTS to test } \\
\text { conformance to all coordinate } \\
\text { systems, specifically those that } \\
\text { are listed by the user under } \\
\text { "Other". }\end{array}$ \\
\hline & 7.7.3 & $\begin{array}{l}\text { A fourteenth optional information item geographic coordinate other system } \\
\text { identifier / OSI allows for other coordinate systems. This information items } \\
\text { specifies the system identifier. It is up to } 10 \text { characters in length. Examples are: } \\
\text { - MGRS (Military Grid Reference System) } \\
\text { - USNG (United States National Grid) } \\
\text { - GARS (Global Area Reference System) } \\
\text { - GEOREF (World Geographic Reference) } \\
\text { - LANDMARK (e.g. hydrant) and position relative to the landmark. } \\
\text { A fifteenth optional information item, is the geographic coordinate other system } \\
\text { value / OCV. It shall only be present if OSI is present in the record. It can be up to } \\
126 \text { characters in length. If OSI is LANDMARK, OCV is free text and may be up } \\
\text { to } 126 \text { characters. For details on the formatting of OCV for the other coordinate }\end{array}$ & $\begin{array}{l}\text { While some examples are listed } \\
\text { (MGRS, USNG, GARS, } \\
\text { GEOREF, LANDMARK), there } \\
\text { may be others that are not listed. } \\
\text { It is not feasible for the CTS to } \\
\text { test conformance to these } \\
\text { coordinate systems, specifically } \\
\text { those that may be included but } \\
\text { are not listed as examples. }\end{array}$ \\
\hline
\end{tabular}




\begin{tabular}{|c|c|c|c|}
\hline & & $\begin{array}{l}\text { systems shown in OSI as examples, see http://earth- } \\
\text { info.nga.mil/GandG/coordsys/grids/referencesys.html }\end{array}$ & \\
\hline $\begin{array}{c}\text { Subject } \\
\text { Acquisition } \\
\text { Profiles } \\
\text { SAP/FAP/IAP }\end{array}$ & $\begin{array}{l}7.7 .5 \\
\text { Table } 8, \\
\text { Table } 9, \\
\text { Table } 10\end{array}$ & $\begin{array}{l}\text { A subject acquisition profile is used to describe a set of characteristics concerning } \\
\text { the capture of the biometric sample. These profiles have mnemonics SAP for face, } \\
\text { FAP for fingerprints and IAP for iris records. }\end{array}$ & $\begin{array}{l}\text { It is not feasible to test if the } \\
\text { image was captured under the } \\
\text { conditions specified by the SAP, } \\
\text { FAP or IAP level as defined in } \\
\text { Tables } 8,9 \text { and } 10 \text {. However, the } \\
\text { fields will be tested for valid } \\
\text { level values. }\end{array}$ \\
\hline $\begin{array}{l}\text { Open and } \\
\text { Closed Paths }\end{array}$ & 7.8 & $\begin{array}{l}\text { Several Record Types define open paths (also called contours or polylines) and / } \\
\text { or closed paths (polygons) on an image. They are comprised of a set of vertices. } \\
\text { For each, the order of the vertices shall be in their consecutive order along the } \\
\text { length of the path, either clockwise or counterclockwise. (A straight line of only } \\
\text { two points may start at either end). A path may not have any sides crossing. No } \\
\text { two vertices shall occupy the same position. } \\
\text { There may be up to } 99 \text { vertices. } \\
\text { An open path is a series of connected line segments that do not close or overlap. A } \\
\text { closed path (polygon) completes a circuit. The closed path side defined by the last } \\
\text { vertex and the first vertex shall complete the polygon. A polygon shall have at } \\
\text { least } 3 \text { vertices. The contours in Record Type-17: Iris image record can be a circle } \\
\text { or ellipse. A circle only requires } 2 \text { points to define it (See Table } 16 \text { ). } \\
\text { There are two different approaches to the paths in this standard. The } 2007 \text { and } \\
2008 \text { version of the standard used paths for Field } 14.025: \text { Alternate finger segment } \\
\text { position(s) / ASEG. } \\
\text { That approach has been retained in this version for all paths except in the } \\
\text { Extended Feature Set (EFS) of Record Type- } 9 \text {. The EFS adopted an approach } \\
\text { expressing the path in a single information item, which is different than that used } \\
\text { in other record types. }\end{array}$ & $\begin{array}{l}\text { Further research is needed to } \\
\text { determine the feasibility of } \\
\text { testing for: } \\
\text {-simple, plane figure } \\
\text {-no sides crossing } \\
\text {-no interior holes }\end{array}$ \\
\hline
\end{tabular}

